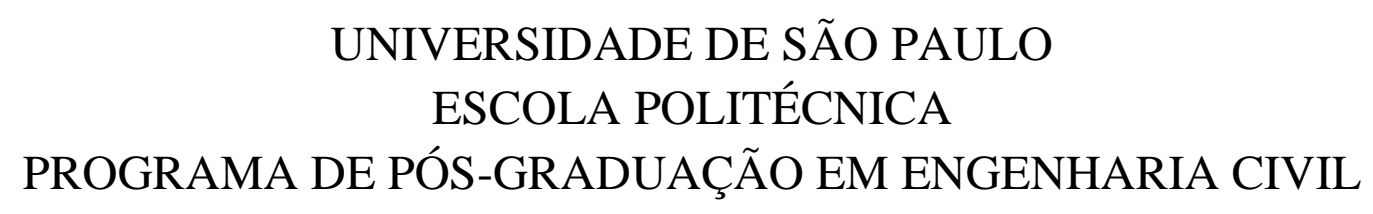

RONNEY RODRIGUES AGRA

INFLUÊNCIA DA TEMPERATURA NO COMPORTAMENTO DO CONCRETO COM DIFERENTES TEORES DE FIBRAS DE AÇO

SÃO PAULO

2021 

RONNEY RODRIGUES AGRA

\section{INFLUÊNCIA DA TEMPERATURA NO COMPORTAMENTO DO CONCRETO COM DIFERENTES TEORES DE FIBRAS DE AÇO}

Versão Corrigida

Dissertação apresentada à Escola Politécnica da Universidade de São Paulo para obtenção do título de Mestre em Ciências.

Área de concentração: Engenharia de Construção Civil e Urbana.

Orientador: Prof. Dr. Antonio Domingues de Figueiredo.

SÃO PAULO 
Autorizo a reprodução e divulgação total ou parcial deste trabalho, por qualquer meio convencional ou eletrônico, para fins de estudo e pesquisa, desde que citada a fonte.

Este exemplar foi revisado e corrigido em relação à versão original, sob responsabilidade única do autor e com a anuência de seu orientador.

São Paulo, 03 de fevereiro de 2021

Assinatura do autor:

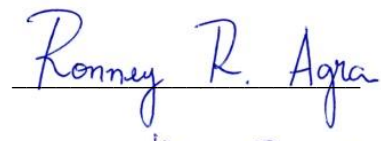

Assinatura do orientador:

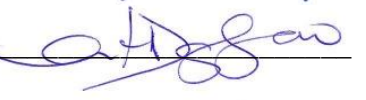

\section{Catalogação-na-publicação}

Agra, Ronney Rodrigues

Influência da temperatura no comportamento do concreto com

diferentes teores de fibras de aço / R. R. Agra -- versão corr. -- São Paulo, 2021. $130 \mathrm{p}$.

Dissertação (Mestrado) - Escola Politécnica da Universidade de São Paulo. Departamento de Engenharia de Construção Civil.

1.Concreto reforçado com fibras 2.Método de ensaio 3.Resistência 4.Temperatura elevada 5.Fogo I. Universidade de São Paulo. Escola Politécnica. Departamento de Engenharia de Construção Civil II.t. 
Aos meus pais, Rommel e Margarete, que me ensinaram, todos os dias, que nada é mais valioso que o bem imaterial da educação. À minha irmã, Isabela, que desde o início me apoiou e encorajou. Se o melhor ensino é o exemplo, esta dissertação começou dentro de casa. A vocês, que me apoiaram incondicionalmente e que foram os maiores incentivadores das minhas vitórias, meu muito obrigado.

À Camila, minha noiva, por ser a melhor pessoa que eu poderia ter ao meu lado, por me motivar neste trabalho e em todos os momentos, por acolher minhas dificuldades, tentando contribuir para a superação destas. Muito obrigado pela paciência, compreensão, amor, carinho e incentivo incondicional. 


\section{AGRADECIMENTOS}

À Deus e Nossa Senhora, por serem o meu ponto de apoio e fé para superar as adversidades impostas pela vida. Das vezes em que fraquejei até os dias de enorme alegria, senti a presença e o suporte seguros da fé e, por isso, continuei.

À minha família, pelo carinho sincero que devota a mim, pela alegria genuína que sente pelas minhas conquistas e pelo grande suporte, mesmo à distância. Vocês que tanto me fortaleceram por meio de visitas, ligações e mensagens, muito obrigado!

Ao Prof. Dr. Antonio Domingues de Figueiredo, que reúne em uma só pessoa inteligência, conhecimento profundo, dedicação e generosidade. Ele que muito me ajudou na construção desta dissertação, enquanto meu orientador e amigo nesses anos de mestrado. Seu fôlego, dinamismo e sua dedicação à ciência são inspiradores. Sou muito grato a Deus por ter me permitido cruzar o seu caminho e aprender tanto.

À Prof ${ }^{a}$. Dra Aline da Silva Ramos Barboza, que, durante meus anos de graduação em Engenharia Civil, despertou em mim o gosto pela pesquisa e o amor pela docência. Agradeço também aos amigos da UFAL: Arthur, Daniel, Kaio e Gabriela por todo o suporte.

Aos Engenheiros MSc. Antonio Fernando Berto e Carlos Roberto Metzker de Oliveira pelos valiosos ensinamentos, orientações e pela grande contribuição na parte laboratorial, proporcionando o apoio necessário à realização deste trabalho.

Aos docentes e pesquisadores do Programa de Pós Graduação em Engenharia Civil da Universidade de São Paulo (PPGEC - USP) que me proporcionaram, além do conhecimento, inspiração para trilhar minha carreira.

Ao meu amigo/irmão Ramoel Serafini agradeço, de forma muito especial, pelo grande incentivo e por ter dividido comigo o peso da rotina. Obrigado pela recepção, encorajamento, conselhos e todo auxílio. Seu suporte e esforço descomunal foram fundamentais para a execução deste projeto. Minha eterna gratidão!

Ao Fiber Team, em especial aos amigos Alan, Daniel e Tiago, pelo estímulo e pelos momentos de alegria que tornaram esse período de trabalho mais gracioso. Agradeço ainda pelo trabalho em equipe, pelo aprendizado mútuo e pelos debates embasados em fundamentação científica que muito acrescentaram ao amadurecimento deste trabalho. 
Aos amigos que foram essenciais para que todas as engrenagens funcionassem em perfeita harmonia: Fábio, Natália, Amanda, Felipe, Julie, Renan, Jéssica, Leonardo, Estevão, Guilherme, Paulo, Sérgio, Daniele, Heitor, Danilo, Pedro, Marcos Vinícius, José Augusto, Luana, Lígia, Carol, Marcel, Mariê, Gabriel, Welles e Jordão. Muito obrigado pelo convívio ao longo desta jornada.

Aos amigos e funcionários do Laboratório de Estruturas e Materiais (LEM), em especial, Jenício, Juca, Jurandir e Rui, pelos ensinamentos, compartilhamento de ideias, bons momentos de descontração, conversas e provocações sadias sobre futebol. Por meio da alegria e o carinho de sempre, vocês facilitaram enormemente a minha rotina.

Aos técnicos, funcionários e amigos do Hall Tecnológico, em especial, Adilson, Jéssica, Mário e Renata, pela assistência prestada e enorme contribuição na realização deste trabalho.

Ao Osmar e ao Rafa, pela ajuda fundamental nos ensaios realizados na Instron.

Aos funcionários e amigos do Laboratório de Segurança ao Fogo e a Explosões (LSFEx) do IPT, em especial, André, Carlos, Írio, Koba, Mozart, Rafa e Rodrigo, pela grande ajuda nos ensaios de fogo.

Aos professores da Comissão Examinadora do Exame de Qualificação, Prof. Dr. Dimas Alan Strauss Rambo e Prof. Dr. Flávio de Andrade Silva, pelas críticas valiosas que contribuíram para a melhoria deste trabalho.

À Wandréa, Eliany, Bete, Carla e Milton pelos esclarecimentos e auxílios nas questões administrativas.

À CAPES pelo apoio financeiro durante a execução deste trabalho.

Ao Instituto de Pesquisas Tecnológicas do Estado de São Paulo (IPT) pela parceria estabelecida por meio do Programa Novos Talentos.

A todos aqueles que mesmo não estando citados aqui fizeram ou fazem parte da minha vida acadêmica e torcem para o meu progresso profissional e pessoal. 
"Acredite em você, na força da sua fé, nas vezes que você teve que remar contra a maré. Acredite em tudo aquilo que lhe torna diferente, em tudo que já passou e no que vem pela frente.

Acredite e não se explique, pois poucos vão entender: só se compreende um sonho, se o sonhador for você. Acredite, pense e faça, use sua intuição, transforme sonho em suor, pensamento em ação".

(Bráulio Bessa, poeta e cordelista nordestino) 


\section{RESUMO}

Medidas de proteção e combate ao incêndio de estruturas de concreto são foco de pesquisas em escala mundial. Sabe-se que a utilização de microfibras poliméricas promove redução no processo de lascamento explosivo do concreto e que sua combinação com fibras de aço promove efeitos benéficos em termos de resistência ao fogo. Entretanto, não há abordagem de normas, projetos e recomendações para o concreto reforçado com fibras (CRF) aplicado em estruturas quando sujeito a incêndio. Nesse contexto, o presente trabalho auxilia na parametrização do comportamento estrutural do CRF submetido a elevadas temperaturas, à medida que avalia a capacidade de reforço proporcionado pelas fibras de aço nestas condições. Neste estudo, o aquecimento do CRF foi realizado em forno elétrico e, também, por meio da exposição unifacial ao fogo. A avaliação do comportamento mecânico pós-fissuração das amostras submetidas a elevadas temperaturas e dosadas com teores distintos de fibras de aço $\left(20,35\right.$ e $70 \mathrm{~kg} / \mathrm{m}^{3}$, o que corresponde, em volume, a $0,26 \%, 0,45 \%$ e $0,90 \%$, respectivamente) foi realizada por meio dos ensaios DEWS (Double Edge Wedge Splitting) e de flexão de três pontos. Apesar da deterioração intensa da resistência à compressão do CRF, sua taxa de degradação ocorreu de forma distinta com a elevação da temperatura, em função do teor de fibras de aço empregado, de modo que amostras com baixos teores apresentaram reduções mais intensas em relação às amostras com teores elevados. A principal preocupação é quanto à resistência à tração, que é significativamente afetada em temperaturas acima de $300{ }^{\circ} \mathrm{C}$. No entanto, também foi constatado efeito positivo proporcionado pelo aumento do teor de fibras, de forma que diminuíram as taxas de degradação nessa propriedade. Além disso, foi constatada a influência direta do aumento do teor de fibras na capacidade resistente pós-fissuração do compósito. Com o aumento da temperatura, as fibras perderam sua capacidade de reforço e, assim, ocorreram reduções gradativas na capacidade resistente residual, de modo que após $600{ }^{\circ} \mathrm{C}$, o CRF conservava apenas $20 \%$ e $30 \%$ da sua resistência à tração pós-fissuração associada ao estado limite de serviço (ELS) e estado limite último (ELU) respectivamente, independente do teor de fibras. Após exposição ao fogo, os valores de resistência à tração da matriz e resistência à tração pós-fissuração associados ao ELU tenderam aos resultados obtidos para a temperatura de 450 ${ }^{\circ} \mathrm{C}$, independente do teor de fibra empregado. Os resultados obtidos poderão ser utilizados para a elaboração de equações constitutivas e servem como dados de entrada em modelos numéricos de previsão de comportamento estrutural de elementos executados com CRF.

Palavras-chave: Concreto reforçado com fibras. Comportamento estrutural. Resistência pósfissuração. Temperaturas elevadas. Resistência ao fogo. 


\begin{abstract}
Fire protection and firefighting measures for concrete structures are research topics in a worldwide scale. It is known that the use of micro-synthetic fibers reduces the occurrence of explosive spalling, and that its use with steel fibers promotes beneficial effects in terms of fire resistance. However, the current standards and recommendations do not provide an adequate approach regarding the use of fiber reinforced concrete (FRC) for structural applications under fire. In this context, the present work aids in the parameterization of the structural behavior of the FRC subjected to high temperatures, as it assesses the reinforcement capacity provided by steel fibers. The heating procedure was conducted using an electric oven, for target temperatures, and a vertical fire simulator that induced a single-surface fire exposure. The post-crack mechanical behavior of samples subjected to high temperatures and produced with different fiber contents $(20,35$ and 70 $\mathrm{kg} / \mathrm{m}^{3}$, which corresponds, in volume, to $0.26 \%, 0.45 \%$ and $0.90 \%$, respectively) was performed using the DEWS (Double Edge Wedge Splitting) test and the classical three-point bending test. Despite the intense deterioration of the FRC compressive strength, the rate of degradation under temperature was reduced for higher contents of steel fibers. The main concern is related to the tensile properties, which are affected for temperatures above $300^{\circ} \mathrm{C}$. However, the increase in fiber content mitigated the degradation rate in the tensile properties of the material. In addition, the influence of the fiber content on the post-crack behavior was characterized. As the temperature increased, the fibers lost their reinforcement capacity and a gradual reduction in the post-crack properties was verified, in which the FRC exposed to $600{ }^{\circ} \mathrm{C}$ retained only $20 \%$ and $30 \%$ of its post-cracking tensile strength at crack openings relative to service limit state (SLS) and ultimate limit state (ULS), respectively, regardless of the fiber content. After exposure to fire, the matrix tensile strength and the ULS post-crack tensile strength tended to the results obtained for the temperature of $450^{\circ} \mathrm{C}$, regardless of the fiber content used. The results obtained may be used for the elaboration of constitutive equations and serve as input data in numerical models that aim to predict the structural behavior of FRC elements.
\end{abstract}

Keywords: Steel fiber reinforced concrete. Structural behavior. Post-crack tensile strength. Elevated temperatures. Fire resistance. 


\section{LISTA DE FIGURAS}

Figura 2.1 - Principais curvas temperatura versus tempo padronizadas existentes na literatura

Figura 2.2 - Taxa de aquecimento interno do concreto: (a) regressão linear; (b) valores de taxa de aquecimento 30

Figura 2.3 - Redução da densidade e resistências à compressão e à tração do concreto em função da temperatura

Figura 2.4 - Curvas tensão-deformação obtidas por meio do ensaio de Duplo Puncionamento de corpos de prova de CRFP submetidos a diferentes temperaturas

Figura 2.5 - Curvas Carga versus CMOD de ensaio de flexão para o CRFP antes e após exposição ao fogo .

Figura 2.6 - Curvas de resistência à tração média por abertura de fissura (COD) do CRFA na temperatura ambiente e após exposição ao fogo

Figura 2.7 - Amostra exposta ao fogo e submetida ao ensaio de flexão da EN 14651 ........... 40

Figura 3.1 - Esquema adotado para o programa experimental deste estudo ........................... 45

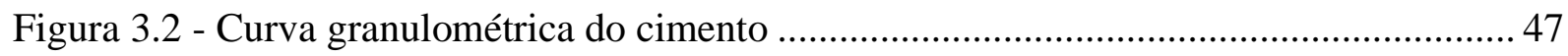

Figura 3.3 - Curva granulométrica da sílica ativa ............................................................. 48

Figura 3.4 - Curvas granulométricas dos agregados miúdos................................................ 48

Figura 3.5 - Curvas granulométricas dos agregados graúdos ............................................... 49

Figura 3.6 - Ilustração da fibra de aço do tipo A, classe I, utilizada neste estudo ................... 50

Figura 3.7 - Forno elétrico utilizado para aquecimento das amostras de pasta de cimento ..... 52

Figura 3.8 - Amostra de pasta de cimento e material utilizado para pulverizá-la .................... 52

Figura 3.9 - Ensaio de abatimento do tronco de cone (slump test) do CRFA ......................... 54

Figura 3.10 - (a) Procedimento para enchimento do molde prismático; (b) Moldes prismáticos

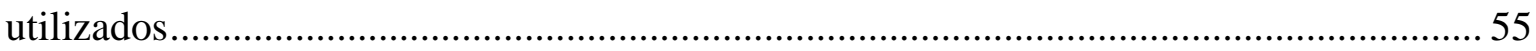

Figura 3.11 - Corte dos corpos de prova prismáticos........................................................... 56

Figura 3.12 - Preparação das amostras cúbicas para o ensaio DEWS ................................... 57

Figura 3.13 - Configuração do corpo de prova para o ensaio DEWS ….................................. 57

Figura 3.14 - (a) Forno elétrico utilizado; (b) amostras no interior do forno após aquecimento

Figura 3.15 - Gráfico temperatura $\left({ }^{\circ} \mathrm{C}\right) \mathrm{x}$ tempo de ensaio (min) obtido durante aquecimento em mufla elétrica 
Figura 3.16 - (a) Posionamento das amostras no quadro de ensaio para o ensaio de fogo direto; (b) manta refratária aplicada em toda superfície da alvenaria

Figura 3.17 - (a) Sistema de aquecimento e (b) situação das amostras após realização do ensaio de exposição ao fogo

Figura 3.18 - Gráfico temperatura $\left({ }^{\circ} \mathrm{C}\right) \mathrm{x}$ tempo de ensaio (min) obtido no ensaio de exposição ao fogo

Figura 3.19 - Aparelhagem de ensaio utilizada para o Método Indutivo

Figura 3.20 - Ensaio de determinação do módulo de elasticidade dinâmico 65

Figura 3.21 - Determinação do módulo estático de elasticidade do CRFA

Figura 3.22 - (a) Desenho esquemático do ensaio DEWS; (b) Setup do ensaio DEWS adotado neste estudo. 68

Figura 3.23 - Configuração do ensaio DEWS para amostras expostas ao fogo 70

Figura 3.24 - Setup do ensaio de flexão de 3 pontos: (a) visão geral; (b) amostra ensaiada sem exposição ao fogo; (c) amostra ensaiada após exposição ao fogo. 72

Figura 3.25 - Posicionamento do clip-gauge no ensaio de flexão de 3 pontos: (a) amostra ensaiada sem exposição ao fogo; (b) amostra ensaiada após exposição ao fogo

Figura 3.26 - Arranjo do ensaio de flexão empregado e posição do entalhe na seção da amostra prismática

Figura 3.27 - Diagrama típico de força versus CMOD, identificando as cargas residuais ...... 75

Figura 4.1 - Composição mineralógica de pastas de cimento expostas a temperaturas elevadas

Figura 4.2 - Contribuição das fibras de aço por eixo para as dosagens: (a) $20 \mathrm{~kg} / \mathrm{m}^{3}$; (b) 35 $\mathrm{kg} / \mathrm{m}^{3}$; (c) $70 \mathrm{~kg} / \mathrm{m}^{3}$. 80

Figura 4.3 - Perda de massa em função da temperatura para as amostras de CRFA 84

Figura 4.4 - Variação do módulo de elasticidade dinâmico e velocidade do pulso ultrassônico em função da temperatura (comportamento para todos os teores de fibra de aço). 84

Figura 4.5 - Curvas tensão-deformação em função da temperatura para os teores de fibras de aço, em volume, de: (a) 0,26\%; (b) 0,45\%; (c) 0,90\% 86

Figura 4.6 - Redução da resistência à compressão e módulo de elasticidade em função da temperatura para os teores de fibras de aço, em volume, de $0,26 \%, 0,45 \%$ e $0,90 \%$.

Figura 4.7 - Curvas médias de resistência à tração por abertura de fissura (COD) do CRFA nas temperaturas em estudo para os teores de fibras de aço em volume: (a) 0,26\%; (b) $0,45 \%$; (c) $0,90 \%$ 
Figura 4.8 - Correlação entre as resistências médias do compósito e a temperatura: (a) resistência à tração da matriz; (b) resistência residual em $0,25 \mathrm{~mm}$; (c) resistência residual em $1,25 \mathrm{~mm}$

Figura 4.9 - (a) Concreto fissurado após exposição à $750{ }^{\circ} \mathrm{C}$; (b) Fibras oxidadas na lateral do corpo de prova

Figura 4.10 - Efeito da temperatura nos parâmetros de ductilidade do CRFA: (a) ELS; (b)

ELU

Figura 4.11 - Ensaio DEWS e condições de integridade das amostras à (a) temperatura ambiente e após aquecimento a (b) $150{ }^{\circ} \mathrm{C}$; (c) $300{ }^{\circ} \mathrm{C}$; (d) $450{ }^{\circ} \mathrm{C}$; (e) $600{ }^{\circ} \mathrm{C}$; (f) $750{ }^{\circ} \mathrm{C}$

Figura 4.12 - Coeficientes de degradação mecânica em comparação com as normas europeias: (a) resistência à tração da matriz; (b) resistência à tração pós-fissuração associada ao ELU

Figura 4.13 - Amostra prismática fissurada após exposição ao fogo, com destaque para as fibras oxidadas 99

Figura 4.14 - Amostras cúbicas com os teores distintos de fibras de aço: (a) Face exposta ao fogo; (b) Vista superior, com destaque para a mudança de cor....

Figura 4.15 - Curvas médias de resistência à tração por abertura de fissura do CRFA antes e após exposição ao fogo: (a) ensaio DEWS; (b) ensaio de flexão 101

Figura 4.16 - Correlação entre as resistências médias e o teor de fibras por meio do ensaio DEWS (25 ${ }^{\circ} \mathrm{C}$ e pós-fogo): (a) resistência à tração da matriz; (b) resistência residual em $0,25 \mathrm{~mm}$; (c) resistência residual em 1,25 mm.

Figura 4.17 - Correlação entre as resistências médias e o teor de fibras por meio do ensaio de flexão ( $25^{\circ} \mathrm{C}$ e pós-fogo): (a) limite de proporcionalidade; (b) resistência residual para $\mathrm{CMOD}=0,5 \mathrm{~mm}(\mathrm{c})$ resistência residual para $\mathrm{CMOD}=2,5 \mathrm{~mm}$

Figura 4.18 - Correlação global média entre as tensões obtidas pelos ensaios de flexão e DEWS 108

Figura 4.19 - Distribuição da temperatura no interior das amostras de CRF em função da distância da face afetada pelo fogo e tempo de exposição ao fogo .

Figura 4.20 - Relação com as tensões obtidas por Serafini et al. (2020b): (a) ensaio DEWS;

(b) ensaio de flexão.

Figura 4.21 - Relação entre as tensões obtidas pelos ensaios de resistência à compressão e DEWS 


\section{LISTA DE TABELAS}

Tabela 2.1 - Ensaios não destrutivos aplicados às amostras de CRF após exposição a elevadas

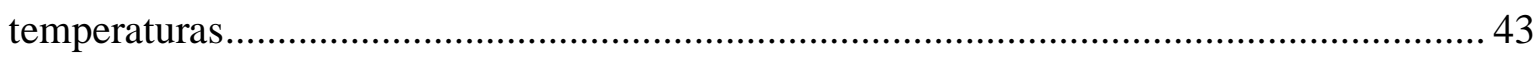

Tabela 3.1 - Ensaios e normas utilizados para caracterização dos agregados .......................... 46

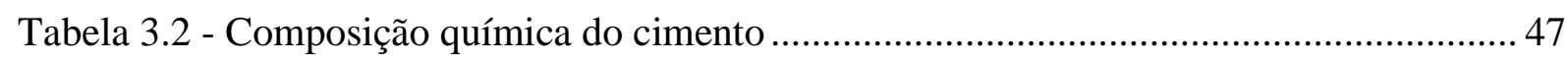

Tabela 3.3 - Especificações do aditivo superplastificante.................................................... 49

Tabela 3.4 - Propriedades das fibras de aço e microfibras de polipropileno............................ 50

Tabela 3.5 - Dosagem de materiais para produção de $1 \mathrm{~m}^{3}$ de CRFA (Teor de fibras de aço =

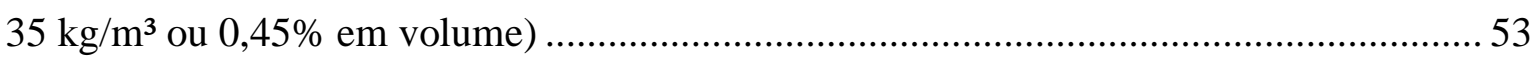

Tabela 3.6 - Ensaios mecânicos conduzidos neste estudo........................................................ 66

Tabela 4.1 - Síntese das mudanças mineralógicas em função da temperatura ......................... 77

Tabela 4.2 - Teor real médio de fibras de aço para as dosagens de projeto: 20,35 e $70 \mathrm{~kg} / \mathrm{m}^{3} 81$

Tabela 4.3 - Valores médios de massa e velocidade de pulso ultrassônico do CRFA para cada

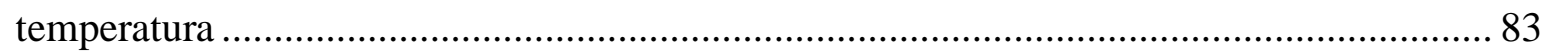

Tabela 4.4 - Valores médios de resistência à compressão e módulo de elasticidade estático por

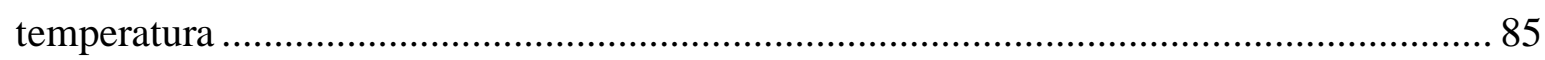

Tabela 4.5 - Valores médios de resistência à tração da matriz $\left(\mathrm{f}_{\mathrm{tc}}\right)$ e resistências residuais $\left(\mathrm{f}_{\mathrm{t} 0,25}\right.$ e $\mathrm{f}_{\mathrm{t} 1,25}$ ) das amostras de CRFA ensaiadas pelo método DEWS

Tabela 4.6 - Valores médios de resistência à tração da matriz $\left(\mathrm{f}_{\mathrm{tc}}\right)$ e resistências residuais $\left(\mathrm{f}_{\mathrm{t} 0,25}\right.$ e $\mathrm{f}_{\mathrm{t} 1,25}$ ) obtidos por meio do ensaio DEWS ( $\mathrm{T}=25^{\circ} \mathrm{C}$ e após exposição ao fogo) 100

Tabela 4.7 - Valores médios de resistência à tração do compósito (f $f_{\mathrm{LOP}}$ ) e resistências residuais $\left(f_{R 1}, f_{R 2}, f_{R 3}\right.$ e $\left.f_{R 4}\right)$ obtidos por meio do ensaio de flexão $\left(T=25^{\circ} \mathrm{C}\right.$ e após exposição ao fogo). 


\section{LISTA DE ABREVIATURAS E SIGLAS}

\begin{tabular}{|c|c|}
\hline ABECE & Associação Brasileira de Engenharia e Consultoria Estrutural \\
\hline $\mathrm{ABNT}$ & Associação Brasileira de Normas Técnicas \\
\hline ACI & American Concrete Institute \\
\hline AENOR & Asociación Española de Normalización y Certificación \\
\hline AFGC & Association Française de Génie Civil \\
\hline ASTM & American Society for Testing and Materials \\
\hline CAR & Concreto de Alta Resistência \\
\hline CEN & European Committee for Standardization \\
\hline CMOD & Crack Mouth Opening Displacement (abertura do entalhe à flexão) \\
\hline COD & Crack Opening Displacement (abertura de fissura à tração direta) \\
\hline $\mathrm{CP}$ & Corpo de prova \\
\hline CP-V ARI & Cimento Portland de Alta Resistência Inicial \\
\hline $\mathrm{CRF}$ & Concreto Reforçado com Fibras \\
\hline CRFA & Concreto Reforçado com Fibras de Aço \\
\hline CRFP & Concreto Reforçado com Fibras Poliméricas \\
\hline $\mathrm{C}-\mathrm{S}-\mathrm{H}$ & Silicato de cálcio hidratado \\
\hline CV & Coeficiente de Variação \\
\hline DEWS & Double Edge Wedge Splitting \\
\hline DPT & Double Punch Test \\
\hline DRX & Difração de Raios X \\
\hline ELS & Estado Limite de Serviço \\
\hline ELU & Estado Limite Último \\
\hline EN & European Norm \\
\hline EPUSP & Escola Politécnica da Universidade de São Paulo \\
\hline$f i b$ & Fédération Internationale du Béton \\
\hline IBRACON & Instituto Brasileiro do Concreto \\
\hline IPT & Instituto de Pesquisas Tecnológicas \\
\hline ISO & International Organization for Standardization \\
\hline JSCE & Japan Society of Civil Engineers \\
\hline LSFEx & Laboratório de Segurança ao Fogo e a Explosões \\
\hline LVDT & Linear Variable Displacement Transducer \\
\hline NBR & Norma Brasileira \\
\hline NIST & National Institute of Standards and Technology \\
\hline PP & Polipropileno \\
\hline RILEM & $\begin{array}{l}\text { International Union of Laboratories and Experts in Construction Materials, } \\
\text { Systems and Structures }\end{array}$ \\
\hline SLS & Serviceability Limit State \\
\hline TBM & Tunnel Boring Machines \\
\hline TRRF & Tempo Requerido de Resistência ao Fogo \\
\hline ULS & Ultimate Limit State \\
\hline UNE & Una Norma Española \\
\hline
\end{tabular}




\section{LISTA DE SÍMBOLOS}

\begin{tabular}{ll}
$\mathrm{t}$ & Tempo \\
$\mathrm{min}$ & Minuto \\
$\mathrm{T}$ & Temperatura \\
$\mathrm{rpm}$ & Rotação por minuto \\
$\mathrm{kV}$ & Quilovolt \\
$\mathrm{L}$ & Indutância medida com campo magnético \\
$\mathrm{L}_{\mathrm{e}}$ & Indutância equivalente \\
$\mathrm{MPa}$ & Megapascal \\
$b$ & Largura da seção transversal do corpo de prova \\
$h$ & Altura da seção transversal do corpo de prova \\
$l$ & Comprimento do vão de ensaio \\
$\mathrm{D}_{\text {máx }}$ & Dimensão máxima característica do agregado \\
${ }^{\circ} \mathrm{C}$ & Grau Celsius \\
$\mathrm{g}$ & Grama \\
$\mathrm{kg}$ & Quilograma \\
$\mathrm{Hz}$ & Hertz \\
$\varepsilon$ & Deformação \\
$\sigma$ & Tensão \\
$\mathrm{mm}$ & Milímetro \\
$\mathrm{cm}$ & Centímetro \\
$\mathrm{m}$ & Metro \\
$\%$ & Porcentagem \\
$\mathrm{f}_{\mathrm{cm}}$ & Resistência média à compressão axial \\
$\mathrm{E}$ & Módulo de elasticidade \\
$\mathrm{mA}$ & Mili ampére \\
$\rho$ & Densidade \\
$\mathrm{N}$ & Newton \\
$\mathrm{kN}$ & Quilonewton \\
$\mathrm{s}$ & Segundo \\
$l_{c}$ & Comprimento crítico da fibra \\
$\mathrm{P}$ & Carga aplicada ao corpo de prova \\
$\theta$ & Ângulo formado entre a superfície do corte em cunha e a linha de centro do \\
$N$ & entalhe do corpo de prova no ensaio DEWS \\
$\mu$ & Componente normal da força de contato \\
$\mu$ & Coeficiente de atrito estático \\
$\mathrm{f}_{\mathrm{tc}}$ & Resistência à tração da matriz \\
$\mathrm{f}_{\mathrm{LOP}}$ & Limite de proporcionalidade \\
$\mathrm{h}_{\mathrm{sp}}$ & Distância entre o topo do entalhe e o topo da amostra \\
$\mathrm{h}$ & Distância entre os extremos dos dois entalhes da amostra no ensaio DEWS \\
$\mathrm{f}_{\mathrm{t} 0,25}$ & Resistência à tração pós-fissuração associada ao Estado Limite De Serviço \\
& $\left(f_{t 0,25}\right)$ obtida pelo ensaio DEWS \\
\hline
\end{tabular}


$\mathrm{f}_{\mathrm{t} 1,25}$ Resistência à tração pós-fissuração associada ao Estado Limite Último $\left(f_{t 1,25}\right)$ obtida pelo ensaio DEWS

$\mathrm{f}_{\mathrm{R} 1} \quad$ Resistência residual à tração na flexão correspondente à $0,5 \mathrm{~mm}$ de CMOD

$\mathrm{f}_{\mathrm{R} 2} \quad$ Resistência residual à tração na flexão correspondente à 1,5 $\mathrm{mm}$ de CMOD

$\mathrm{f}_{\mathrm{R} 3} \quad$ Resistência residual à tração na flexão correspondente à 2,5 mm de CMOD

$\mathrm{f}_{\mathrm{R} 4} \quad$ Resistência residual à tração na flexão correspondente à 3,5 $\mathrm{mm}$ de CMOD

$\mathrm{f}_{\mathrm{Ftu}} \quad$ resistência à tração pós-fissuração sob tensão uniaxial

$\mathrm{K}_{\mathrm{c}} \quad$ Coeficiente de degradação mecânica da resistência à compressão

$\mathrm{K}_{\mathrm{c}, \mathrm{t}} \quad$ Coeficiente de degradação mecânica da resistência à tração

$\mathrm{K}_{\mathrm{Ft}(\mathrm{ELU})} \quad$ Coeficiente de degradação mecânica da resistência à tração pós-fissuração associada ao Estado Limite Último 


\section{SUMÁRIO}

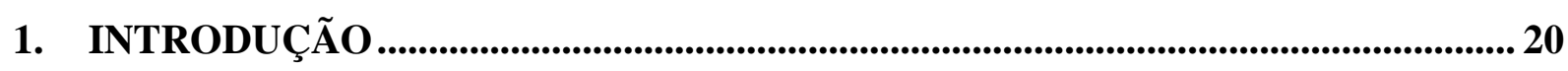

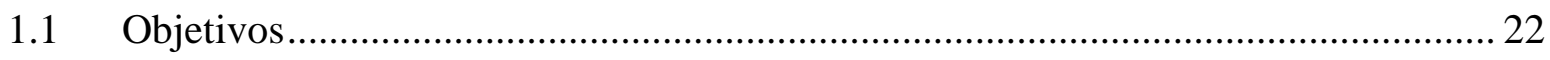

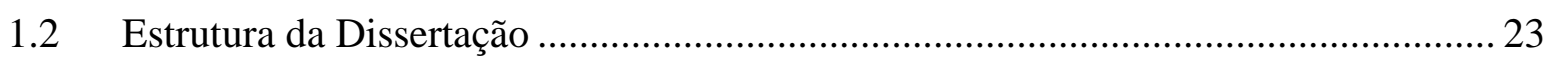

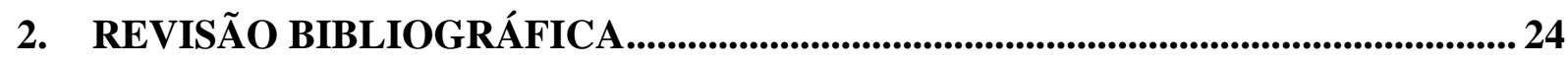

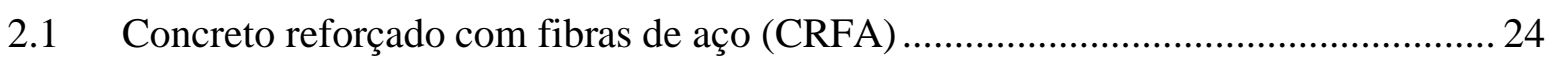

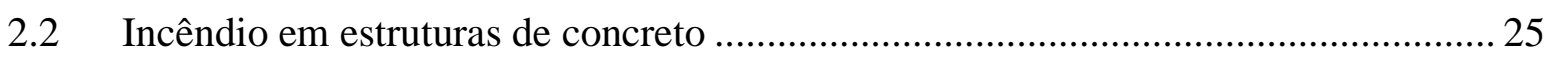

2.2.1 Avaliação de estruturas quanto à ação de incêndio ............................................. 25

2.2.2 Requisitos normativos e códigos-modelo para o CRF em situação de incêndio 27

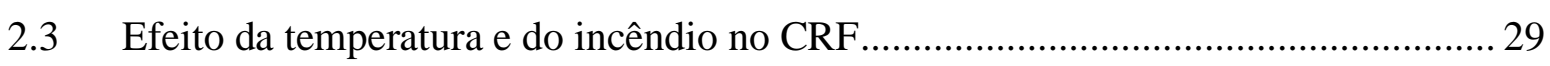

2.3.1 Gradiente de temperatura no concreto exposto ao fogo ..................................... 29

2.3.2 Influência das fibras no fenômeno de lascamento explosivo ............................. 30

2.3.3 Alterações físico-químicas na microestrutura do CRF.................................... 31

2.3.4 Propriedades mecânicas associadas à matriz.................................................... 33

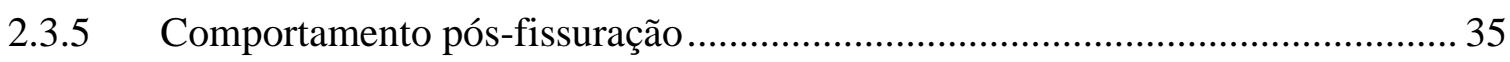

2.4 Técnicas de caracterização do CRF submetido a elevadas temperaturas .................. 39

2.4.1 Técnicas de caracterização das propriedades de tração....................................... 39

2.4.2 Avaliação por meio de técnicas não destrutivas............................................... 43

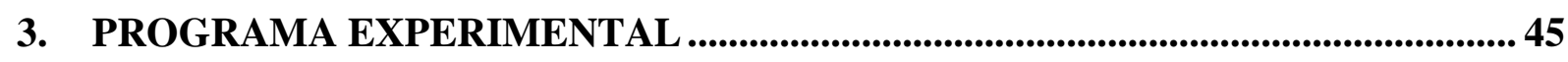

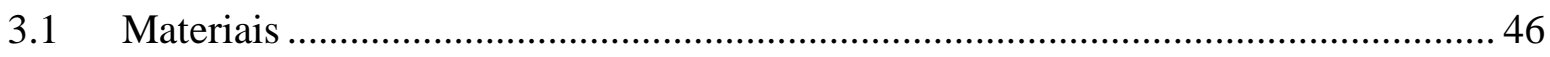

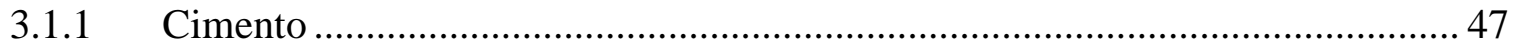

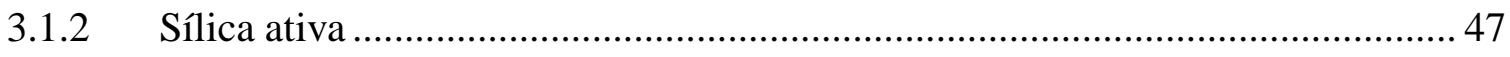

3.1.3 Agregados miúdos .............................................................................. 47

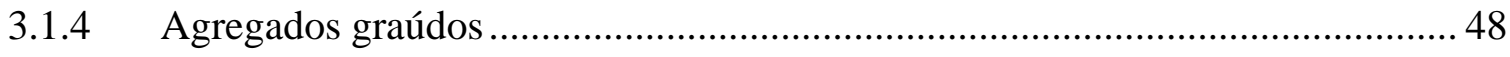

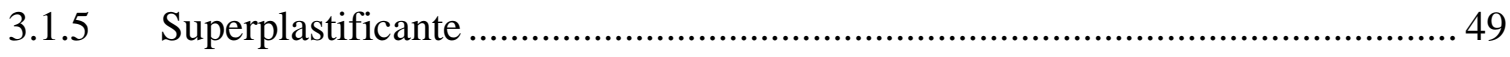

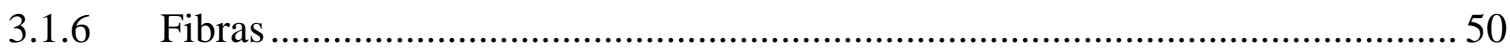

3.2 Procedimentos adotados para a caracterização da microestrutura da matriz ............. 51

3.2.1 Produção, moldagem e cura ............................................................................. 51

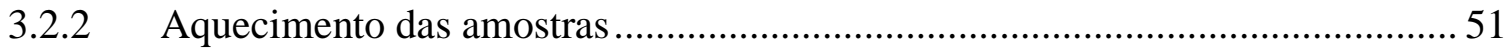

3.2.3 Caracterização mineralógica por Difração de raios X (DRX) ……......................52

3.3 Composição e preparação das amostras de CRFA ….............................................. 53

3.4 Procedimentos de aquecimento empregados para o CRFA......................................58

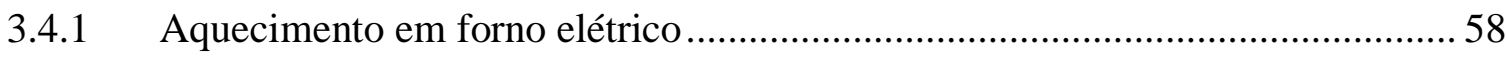

3.4.2 Exposição unifacial ao fogo (simulação por meio da curva " $H$ ”) ........................ 60 
3.5 Avaliação do CRFA por meio de ensaios não destrutivos ....................................... 63

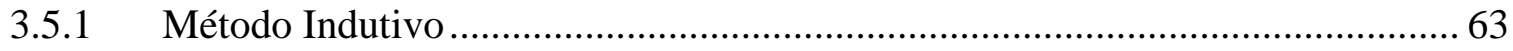

3.5.2 Perda de massa e módulo de elasticidade dinâmico ............................................ 64

3.6 Avaliação do CRFA por meio de ensaios mecânicos ................................................ 66

3.6.1 Resistência à compressão e módulo estático de elasticidade .............................. 66

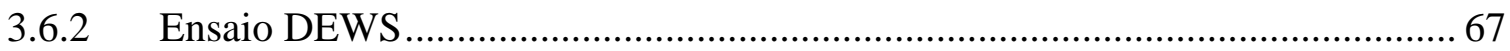

3.6.3 Determinação da resistência à tração na flexão................................................... 71

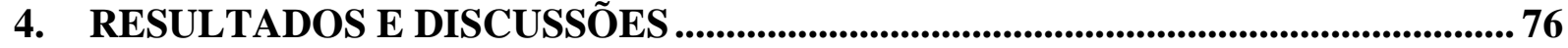

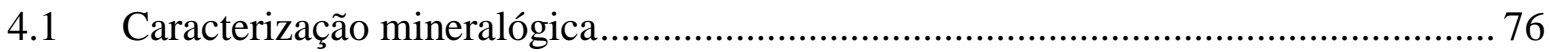

4.2 Teor médio de fibras de aço nas amostras de CRFA ................................................. 79

4.3 Avaliação do CRFA após exposição a elevadas temperaturas .................................. 81

4.3.1 Perda de massa, densidade e módulo de elasticidade dinâmico.......................... 81

4.3.2 Resistência à compressão e módulo de elasticidade estático .............................. 85

4.3.3 Resistência à tração e resistência à tração pós-fissuração .................................. 89

4.3.4 Coeficientes de degradação mecânica ................................................................. 96

4.3.5 Instabilidade pós-fissuração e a determinação da resistência no ensaio DEWS 97

4.4 Efeito do fogo nas propriedades de tração do CRFA ……....................................... 99

4.4.1 Relação entre os ensaios de flexão e DEWS ................................................... 106

4.4.2 Gradiente de temperatura e relação com os resultados em temperaturas

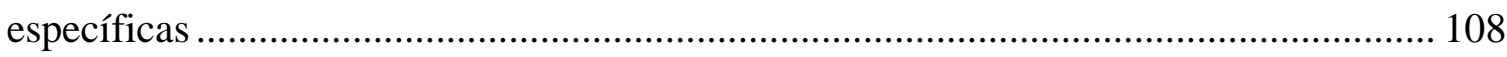

4.4.3 Influência do fator escala nos resultados de flexão e DEWS ........................... 110

4.4.4 Relação entre as resistências à compressão e à tração ..................................... 111

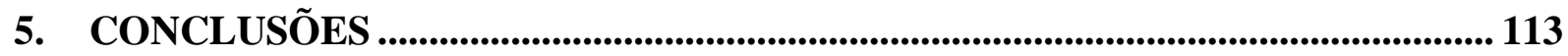

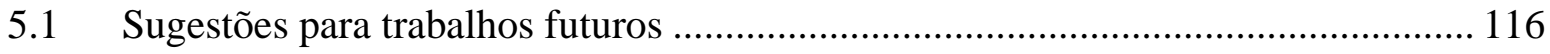

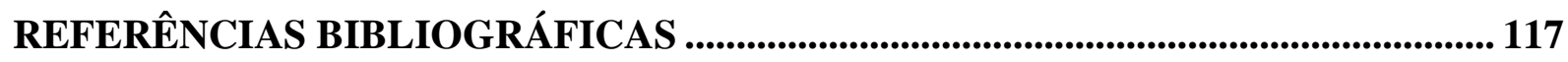

APÊNDICE A: Curvas individuais experimentais obtidas por meio do Ensaio DEWS e representação da região de instabilidade pós-pico.......................................................... 125

APÊNDICE B: Erro admissível e tamanho amostral ........................................................ 129 


\section{INTRODUÇÃO}

O uso crescente do concreto reforçado com fibras (CRF) na construção civil e, em especial, em túneis, se deve a razões econômicas e técnicas. Um avanço importante aconteceu com a publicação do fib Model Code 2010 (FIB, 2013) que parametrizou a utilização do CRF para fins estruturais (DESTRÉE, 2009; BARROS et al., 2012) e se consolidou na área de túneis após a publicação do fib Bulletin 83 (FIB, 2017), que parametrizou sua utilização para o revestimento de túneis produzidos com anéis segmentados executados com tuneladoras TBM (Tunnel Boring Machines). Essa publicação possui uma abordagem próxima àquela adotada no Brasil através das práticas recomendadas do Instituto Brasileiro do Concreto (IBRACON) e vêm sendo base dos textos ora em discussão na Associação Brasileira de Normas Técnicas (ABNT) sobre o tema. Nessa abordagem, é fundamental a parametrização do comportamento do CRF através do estabelecimento de equações constitutivas que caracterizem a capacidade resistente do compósito até a fratura da matriz, em conjunto com as resistências residuais pós-fissuração.

A utilização de fibras de aço tende a encarecer o custo do concreto, de forma que mesmo em consumos regulares, inferiores a $1 \%$ de adição de fibras, o custo unitário do concreto praticamente dobra (FIGUEIREDO, 2011a). Por outro lado, há também o impacto negativo do uso de fibras na trabalhabilidade do concreto (FIGUEIREDO; CECCATO, 2015), o que faz com que se busque sempre minimizar o consumo de fibras para otimizar a aplicação do material. Neste sentido, busca-se o consumo mínimo adequado de fibras que garanta o comportamento dúctil do compósito, a segurança durante seu manuseio e evite uma ruptura brusca do compósito à medida que garanta o controle da abertura de fissuras no elemento estrutural.

O controle de fissuras no revestimento de túneis construídos com anéis segmentados é crítico (LIAO et al., 2015), visto que essas podem ser originadas por esforços de flexão relacionados aos fenômenos dinâmicos associados às situações transitórias de desmoldagem, giro, estocagem e transporte (de la FUENTE et al., 2017) e aos eventos atípicos, como incêndios. Especial atenção deve ser dada a acidentes com incêndio em túneis, visto que constituem as obras de infraestrutura com riscos de danos críticos neste tipo de sinistro (PÉREZ, 2016). O aumento da temperatura dos elementos estruturais provoca redução da resistência mecânica (à compressão e à tração) e do módulo de elasticidade do CRF, além do aparecimento de esforços adicionais decorrentes das restrições às deformações de origem térmica (SILVA, 2012), o que pode comprometer a sua estabilidade. 
Há diversos exemplos históricos de acidentes, em vista do reconhecimento tardio de que as estruturas de concreto devem ser verificadas para a condição de incêndio. Entretanto, requisitos normativos e pré-normativos nacionais e internacionais, bem como códigos-modelo, não apresentam abordagem adequada e abrangente de projeto para o CRF em situação de incêndio, o que pode conduzir a soluções ineficientes, colocando em risco a segurança estrutural nessas condições (DEHN; HERRMANN, 2017). A escassez de base normativa para o modelo de projeto em situação de incêndio do CRF e o fato de que as normas e projetos de norma atuais como é o caso da EN 1992-1-2 (2004) e fib Model Code 2010 (FIB, 2013) - estabelecem apenas como deve ser realizado o projeto estrutural do CRF em temperatura ambiente, revelam a necessidade de investigações a respeito do comportamento do CRF em situação de incêndio, o que serviu de motivação para realização deste trabalho.

Embora os estudos focados no efeito do fogo em túneis sejam escassos na literatura, destaca-se o trabalho realizado por Serafini et al. (2019a), que avaliou o efeito do fogo nas propriedades mecânicas do concreto reforçado com macrofibras sintéticas para aplicações em revestimento de túneis. Os resultados mostram que um gradiente de temperaturas é induzido no interior do compósito com a elevação da temperatura. Essa verificação, no entanto, só é possível por meio de ensaios de aquecimento em fornos com a ação direta de chama, o que permite análises reais de simulação de incêndio para a avaliação pós-incêndio das estruturas de CRF. Nesse sentido, faz-se necessário também investigar os efeitos das elevadas temperaturas em concretos reforçados com fibras de aço, uma vez que estas podem ser utilizadas como reforço primário no revestimento de túneis (CONFORTI et al., 2017).

Considerando o exposto até aqui, esta dissertação procura contribuir para a parametrização da ação da elevada temperatura no comportamento do concreto reforçado com fibras de aço (CRFA) com diferentes teores de fibras de aço, especialmente no que se refere aos critérios de desempenho do ponto de vista estrutural. As variações microestruturais do CRF causadas pelo aumento da temperatura foram investigadas por meio de técnica de caracterização específica, em conjunto com a análise das propriedades mecânicas residuais (pós-incêndio) por meio de ensaio de flexão em amostras de dimensões reduzidas em relação ao preconizado pela norma europeia EN 14651 (2007), o que constitui uma adaptação na metodologia de ensaio de avaliação para fins estruturais. O comportamento mecânico do CRFA após exposição a altas temperaturas também foi investigado por meio do ensaio DEWS (Double Edge Wedge Splitting), metodologia de avaliação da resistência à tração residual que se apresentou tecnicamente viável nestas condições. Por meio deste ensaio foi possível caracterizar o CRFA 
mesmo em severas condições, constituindo assim uma alternativa interessante, principalmente porque permite a obtenção dos valores de resistência à tração direta associados a níveis de fissuração do compósito, o que é fundamental para o estabelecimento de equações constitutivas e para avaliação da segurança estrutural, em concordância com o fib Model Code.

Os resultados obtidos buscam contribuir para minimizar as limitações técnicas no tema concreto reforçado com fibras de aço (CRFA) submetido a elevadas temperaturas (por meio de aquecimento em fornos elétricos ou por exposição unifacial das amostras ao fogo), à medida que procuram parametrizar o comportamento do compósito nestas condições.

\subsection{Objetivos}

O presente estudo tem como objetivo principal parametrizar o comportamento do CRFA em função de sua exposição a temperaturas elevadas. Procurou-se avaliar a capacidade de reforço pós-fissuração das fibras de aço e verificar se há, em termos de parâmetros de resistência residual do CRFA, uma tendência estabelecida. Em complementação, são formulados os seguintes objetivos específicos:

- Realizar uma análise dos métodos de ensaio disponíveis para caracterização do CRF para verificar sua adequação à avaliação do efeito da alta temperatura na resistência pósfissuração do material;

- Avaliar a influência do teor de fibra de aço na alteração do comportamento do CRF em função da temperatura;

- Correlacionar os resultados dos ensaios mecânicos obtidos após a exposição ao fogo com o comportamento do CRF avaliado em ensaios com aquecimento controlado até uma temperatura de referência;

- Obter os coeficientes de degradação das propriedades mecânicas em função da temperatura e verificar sua adequação em relação às normativas internacionais. 


\subsection{Estrutura da Dissertação}

No capítulo 1 apresentam-se a introdução da pesquisa, as lacunas existentes no cenário atual e a importância deste estudo. Nele também são apresentados os objetivos gerais e específicos.

No capítulo 2 encontra-se a revisão bibliográfica realizada, a qual considera-se a base teórica necessária para a elaboração desta dissertação. Neste item é apresentada e discutida a literatura sobre o concreto reforçado com fibras e suas aplicações; a caracterização do incêndio nas estruturas de concreto, com ênfase nas curvas padronizadas de incêndio e no fenômeno de lascamento explosivo (spalling), abordando também os requisitos normativos e códigos-modelo para o CRF em situação de incêndio; os efeitos de temperaturas elevadas no CRF, seja no comportamento mecânico ou nas propriedades de microestrutura; a investigação pós-incêndio a partir da avaliação por meio de ensaios não destrutivos e técnicas de avaliação da resistência à tração pós-fissuração do CRF.

No capítulo 3 relata-se todo o programa experimental adotado, abrangendo a escolha e caracterização dos materiais, procedimentos de moldagem e cura dos corpos de prova, procedimentos de aquecimento adotados (forno elétrico ou simulação de incêndio) e os métodos de ensaio empregados, descrevendo também os equipamentos utilizados.

No capítulo 4 apresentam-se as análises e discussões dos resultados, abordando os resultados do método de determinação do teor de fibras nas amostras; dos ensaios de resistência à compressão; módulo de elasticidade (estático e dinâmico); resistência à tração da matriz e resistência à tração pós-fissuração para todas as temperaturas específicas e teores de fibras de aço adotados neste estudo, além do efeito do fogo nas propriedades de tração do compósito.

No capítulo 5 apresentam-se as conclusões da pesquisa, obtidas a partir da análise dos resultados experimentais.

No capítulo de referências são mostradas todas as referências da literatura utilizadas para esta pesquisa, composta por artigos, normas, capítulos de livros, dissertações e teses.

No apêndice A apresentam-se as curvas individuais experimentais obtidas por meio do ensaio DEWS para os teores de fibra de aço adotados neste estudo.

No apêndice B é apresentado o estudo de tamanho amostral para o ensaio DEWS em função do erro admissível. 


\section{REVISÃO BIBLIOGRÁFICA}

\subsection{Concreto reforçado com fibras de aço (CRFA)}

A principal atuação das fibras ocorre na fase pós-fissuração do concreto, na qual inibem a propagação das fissuras por meio do mecanismo de transferência de tensões pelas próprias fissuras. Dessa maneira, mesmo após a fissuração do compósito, este pode apresentar resistência residual a esforços aplicados, reduzindo as chances de ruptura brusca (FIGUEIREDO, 2011b).

O acréscimo das fibras deve ser controlado a fim de não prejudicar a mobilidade dos agregados do concreto no estado fresco. A perda de mobilidade devido à utilização de elevados teores de fibra dificulta a compactação do concreto, aumentando sua porosidade e, com isso, pode ocorrer perda de resistência mecânica da matriz (FIGUEIREDO; CECCATO, 2015). Por outro lado, a influência das fibras sobre as resistências à compressão e tração do compósito é pouco significativa quando o teor é baixo.

Uma das vantagens da utilização do CRF está no fato de toda a peça ser reforçada, devido à distribuição aleatória das fibras no compósito, tornando-se mais vantajosa sua utilização em estruturas cujos esforços não se concentram em uma área específica (JANSSON et al, 2008) e que apresentem capacidade de redistribuição dos mesmos (di PRISCO; PLIZZARI; VANDEWALLE, 2009). As fibras podem substituir parte da armadura convencional, facilitando a produção dos elementos estruturais por eliminar ou reduzir a etapa de montagem da armadura. Consequentemente, o tempo de obra e os prejuízos no desperdício de materiais são reduzidos (LIAO et al., 2015). As vantagens aplicativas proporcionadas pelas fibras facilitam a viabilização do CRF em pavimentos industriais e aeroportuários, taludes, almofadas de apoio de pontes, tubos de concreto e, principalmente, no revestimento de túneis, como aduelas pré-moldadas ou associado muitas vezes ao concreto projetado.

Em virtude da intensificação da utilização do CRF, acompanhando o crescimento de obras de infraestrutura, um maior controle de produção passou a existir em todo o mundo. Em 2015, no Brasil, o Comitê 303 IBRACON/ABECE foi criado com o objetivo de desenvolver um documento de práticas recomendadas para melhor uso desse tipo de compósito a partir de diversos estudos acadêmicos. Este comitê gerou a base da documentação em discussão atualmente na ABNT que abordará a normalização do CRF para aplicações estruturais. 
$\mathrm{Na}$ fase de dimensionamento, os carregamentos devem ser analisados de forma cuidadosa para alcançar segurança na estabilidade das estruturas de CRF. O projetista deve estar atento à verificação ante as ações de caráter excepcional, como ações devidas ao incêndio, reconhecidas pelo Eurocode 1 (EN 1991-1-2, 2004) como uma situação acidental que compromete o estado limite de serviço (ELS) da estrutura e requer apenas verificações no estado limite último (ELU), associado com colapso estrutural ou outras formas semelhantes de falha estrutural, tais como falha por deformação excessiva. Nesse sentido, é importante entender a influência da alta temperatura e da ação do incêndio no CRF.

\subsection{Incêndio em estruturas de concreto}

\subsubsection{Avaliação de estruturas quanto à ação de incêndio}

O fogo constitui o principal fator de risco para a segurança de estruturas de concreto e podem causar efeitos extremamente adversos em relação às perdas humanas e colapso estrutural. As perdas e lesões por conta de incêndio devem ser evitadas com rigor, visto que há preocupações e dúvidas se as estruturas existentes garantem o mínimo de segurança.

A curva que fornece a temperatura média dos gases quentes em função do tempo é muito importante para caracterizar um incêndio. É comum adotar uma distribuição uniforme de temperaturas após o início do incêndio (SILVA, 2012). Entre as possíveis curvas de crescimento de temperatura pelo tempo, as quais os elementos estruturais estão submetidos, destacam-se: (a) a curva de incêndio natural; (b) a curva de incêndio padrão, padronizada por normas técnicas e representadas por equações; e (c) a curva de incêndio de projeto, criada por meio das variáveis que influenciam o incêndio, tais como carga de incêndio, condições de ventilação e isolamento térmico do ambiente (MORENO JUNIOR; MOLINA, 2012).

A curva de incêndio natural, devido à sua complexibilidade, é substituída por curvas mais simples, como a curva de incêndio padrão quando da avaliação de elementos quanto à sua resistência ao fogo. Os ensaios de laboratório de corpos de prova de CRF expostos a altas temperaturas são comumente realizados em fornos elétricos com uma elevação padronizada de temperatura do ambiente interno, empregando uma curva de aquecimento como modelo de incêndio-padrão com base na ISO 834 (1990) e recomendada pelo Eurocode 1 (EN 1991-1-2, 2002) e pelas normas brasileiras NBR 14432 (ABNT, 2001) e NBR 5628 (ABNT, 2001). Essa curva padrão tem por base uma curva similar recomendada pela ASTM E119 (ASCE, 2000) e independe das características do ambiente e da carga de incêndio, além de admitir que a 
temperatura é sempre crescente com o tempo. A curva ISO 834 (1990) é aplicável quando a carga de incêndio é, fundamentalmente, oriunda de material celulósico. Quando a carga de incêndio consiste em materiais à base de hidrocarbonetos, o incêndio tende a ser mais severo e a curva H (EN 1991-1-2, 2002) é recomendada para esta situação.

O elemento estrutural de concreto, para ser avaliado como resistente ao fogo e seguro contra incêndio, deve obedecer os requisitos fundamentais de (a) resistência estrutural ao fogo, referente à estabilidade estrutural quando submetido ao incêndio; (b) estanqueidade, a fim de não ocorrer alastramento de gases tóxicos e chamas para outras regiões; e (c) isolamento térmico, para manter a temperatura confinada no ambiente do incêndio (PURKISS, 2007). Dessa maneira, uma estrutura segura em situação de incêndio é capaz de resistir aos esforços solicitantes em temperaturas elevadas, evitando o colapso. Em estruturas que possuem grandes dimensões e apresentam condições variáveis de ventilação, como no caso dos túneis, existe grande preocupação com as exigências desses requisitos.

As consequências dos acidentes que envolvem transporte de cargas perigosas nos túneis são percebidas numa escala de impacto social. Geralmente, a gestão da segurança no que diz respeito aos acidentes com cargas perigosas visa reduzir a frequência de eventos de incêndio (NTZEREMES; KIRYTOPOULOS, 2019). Por esse motivo, curvas rigorosas como a RWS e a H (EN 1991-1-2, 2002) são recomendadas para dimensionamento de túneis (COSTA, 2008). Em geral, incêndio em túneis, onde o CRF é muito empregado, possui perfil próprio, caracterizado por ser de longa duração, ter elevado pico de temperatura e elevada taxa de aquecimento, além de não apresentar distribuição uniforme de temperatura (YAN et al., 2015). A Figura 2.1 apresenta uma comparação entre as principais curvas de regime de aquecimento.

As normas técnicas brasileiras poderiam inserir curvas de incêndio para análises estruturais específicas como, por exemplo, na verificação nos túneis. Logo, ainda existem muitas questões e temáticas que podem ser acrescentadas nas normativas brasileiras, frutos das atuais discussões e pesquisas na área. Vale salientar que utilizar modelos, ábacos, boletins e normas internacionais pode gerar imprecisões e incertezas de cálculos, principalmente porque se baseiam em traços de concreto que podem ter características diferentes dos utilizados no Brasil (ZAGO et al., 2015). 
Figura 2.1 - Principais curvas temperatura versus tempo padronizadas existentes na literatura

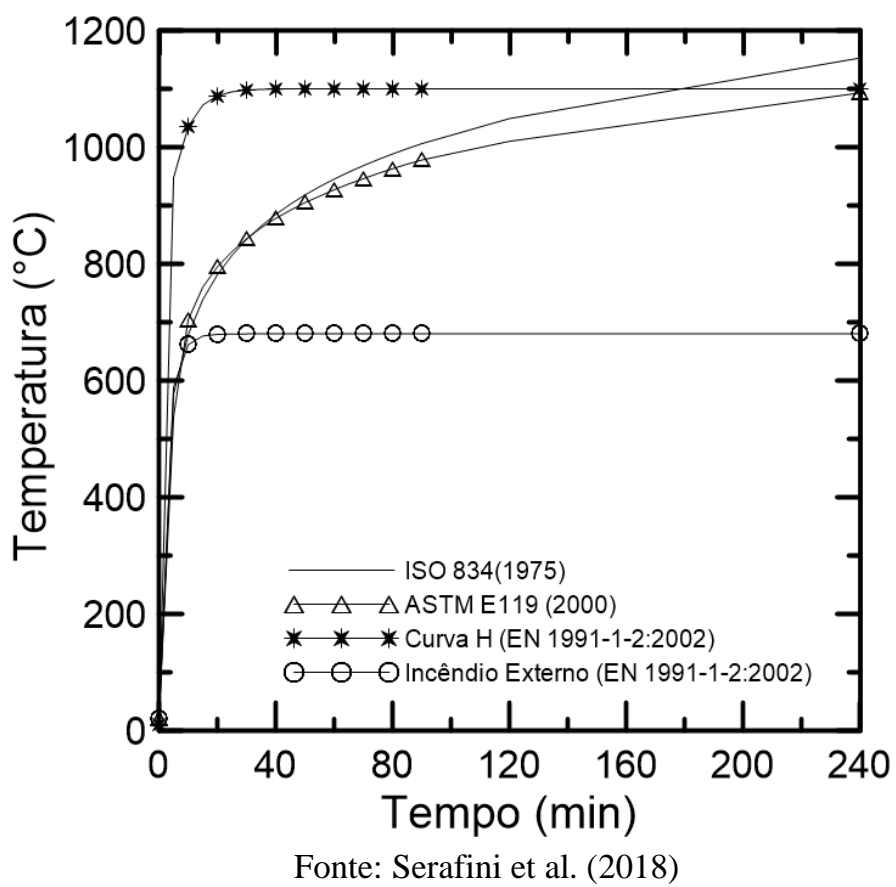

\subsubsection{Requisitos normativos e códigos-modelo para o CRF em situação de incêndio}

Dehn e Herrmann (2017) realizaram um estudo investigativo a respeito da existência de normas e publicações que tratam da resistência do CRFA ao fogo ou a elevadas temperaturas. A prática recomendada alemã sobre CRF (DAfStb, 2012) adicionada a versão alemã da EN 1992-1-2 (DIN EN 1992-1-2, 2010) define que o CRFA pode ser classificado como elemento de concreto simples para verificação da segurança a incêndios.

A norma da Associação Francesa de Engenharia Civil (AFGC, 2013) trata apenas do Concreto de Ultra Alto Desempenho Reforçado com Fibras e define que cada traço desse compósito deve ser analisado por meio de ensaios normalizados de exposição ao fogo. O guia italiano de projeto de estruturas de CRF, CNR-DT 204/2006 (CNR, 2006) apresenta apenas um coeficiente de dano que representa a redução da resistência residual de corpos de prova de CRF submetidos a elevadas temperaturas em relação às amostras ensaiadas à temperatura ambiente.

O Comitê ACI 544, por meio da publicação do ACI 544.5R-10 - Relatório sobre as propriedades físicas e a durabilidade do CRF - atenta que o CRFA exposto ao fogo apresenta falha mais lenta quando comparado com o concreto simples, concluindo que o uso de fibras de aço melhora a resistência do concreto.

O fib Bulletin 38, intitulado "Projeto de Estruturas de Concreto em Situação de Incêndio: Materiais, estruturas e modelagem" não apresenta informações sobre o projeto em situação de 
incêndio do CRFA, assim como o fib Model Code 2010 (FIB, 2013) que contém apenas especificações de projeto em situação de incêndio para estruturas de concreto convencionais, tratando de projeto de estruturas de CRF apenas em condições ambientes normais. O fib Bulletin 46, intitulado "Projeto de Estruturas de Concreto em Situação de Incêndio: Comportamento estrutural e avaliação" indica que as fibras de aço aumentam a resistência residual do concreto após exposição a elevadas temperaturas e aumentam a energia de fratura do concreto.

No Brasil, após um longo período de negligência com relação à segurança contra incêndio, começaram a ser criadas recomendações, regulamentações e normas neste cenário. O órgão responsável pela fiscalização do cumprimento destas normatizações é o Corpo de Bombeiros Militar de cada estado, sendo necessário um laudo técnico de um engenheiro projetista para afirmar que as recomendações foram cumpridas. A Prática Recomendada elaborada pelo CT 303 (Comitê Técnico IBRACON/ABECE) não apresenta informações sobre o projeto em situação de incêndio do CRFA, tanto no GT1 - Projeto de Estruturas de Concreto Reforçado com Fibras - quanto no GT4 - Controle da Qualidade do Concreto Reforçado com Fibras. O CT 305 - Comitê Técnico de Segurança das Estruturas de Concreto contra Incêndio - também não especifica procedimentos de projeto de estruturas de CRF em situação de incêndio.

Em 2001 foi elaborada no Brasil a NBR 14432 (ABNT, 2001), intitulada "Exigências de resistência ao fogo de elementos construtivos de edificações", a qual apresenta a classificação do tempo requerido de resistência ao fogo (TRRF) dos elementos construtivos. Esse fator leva em consideração as possibilidades de ruína frente ao incêndio, fornecendo para o dimensionamento da estrutura uma segurança admissível. A NBR 6118 (ABNT, 2014) apesar de citar a relevância das ações térmicas provocadas na estrutura por meio do incêndio, não apresenta forma de projetar a estrutura nessas condições e apenas apresenta a necessidade de um maior cobrimento, respeitando as dimensões mínimas do elemento estrutural. Para este fim, foi elaborada a NBR 15200 (ABNT, 2012), intitulada "Projeto de estruturas de concreto e situação de incêndio" e dirigida principalmente a edificações industriais e comerciais, onde o concreto pré-moldado é constantemente utilizado, porém não contempla o CRF.

A área de segurança estrutural em situação de incêndio avançou bastante no mundo inteiro após a ocorrência de várias tragédias que resultaram em diversas perdas humanas, entretanto ainda há necessidade de aprimoramento de novos métodos de cálculo visando a precisão e a praticidade, especialmente no que se refere ao desenvolvimento da segurança contra incêndio nas estruturas de CRF. Nos últimos anos, o avanço dessa tecnologia não foi acompanhado pelo aprimoramento da segurança ao fogo das estruturas, o que aponta a necessidade de 
aprofundamento de estudos no que concerne à requisitos, métodos de ensaio e procedimentos para projeto de estruturas de CRF quando submetidas à ação do fogo.

Além disso, uma vez que todos os incêndios têm uma duração finita e na maioria dos casos as estruturas de concreto não colapsam, a capacidade residual após o incêndio também deve ser considerada e avaliada, uma vez que reconstruir uma estrutura ou reforçar os elementos danificados têm grandes implicações econômicas. Assim, para uma escolha correta do procedimento a ser tomado, é necessário o conhecimento das propriedades residuais do compósito (FIB, 2008).

\subsection{Efeito da temperatura e do incêndio no CRF}

\subsubsection{Gradiente de temperatura no concreto exposto ao fogo}

As propriedades mecânicas do concreto são afetadas em função da profundidade até a face mais próxima do fogo, visto que é induzido em seu interior um gradiente de temperatura em um cenário de incêndio, gerando assim diferentes camadas de desidratação da pasta de cimento e microfissuras (SERAFINI et al., 2019a). Temperaturas variáveis são registradas nas camadas internas devido ao baixo coeficiente de condutividade térmica do concreto, o que acaba preservando uma parcela da resistência mecânica do material em seções distantes do fogo. Dessa maneira, qualquer avaliação das propriedades mecânicas globais do concreto exposto ao fogo resulta na resposta mecânica média das camadas afetadas.

A diferença de temperatura observada na seção de um material depende de alguns fatores como a gravidade do incêndio em termos de duração e temperaturas máximas, a rapidez do início do incêndio, a forma da seção e suas propriedades térmicas (FIB, 2008). Além disso, variáveis como o tipo de agregado, regime de aquecimento empregado e relação água/cimento podem influenciar diretamente na determinação da condutividade térmica do concreto (KODUR; SULTAN, 2003). Entretanto, o tipo e a adição de fibras não exercem influência significativa nessa propriedade (LIU et al., 2017). Logo, a formação do gradiente de temperatura no CRF não difere do que ocorre no concreto simples e poucos são os estudos que enfatizam seu impacto nas propriedades mecânicas do CRF exposto ao fogo.

No estudo realizado por Serafini et al. (2019a) verificou-se que, à medida que o tempo de exposição do CRF ao fogo aumenta, a temperatura interna do concreto aumenta em taxas diferentes para cada profundidade avaliada. Além disso, a temperatura interna do concreto diminui rapidamente em maiores profundidades em relação à chama, como pode ser 
comprovado na Figura 2.2, que apresenta os valores de regressão linear (Figura 2.2a) e taxas de aquecimento interno em função da profundidade (Figura 2.2b) para os resultados experimentais obtidos neste estudo. Os resultados indicam que a taxa de aquecimento interno do CRF é praticamente constante para uma determinada profundidade e é função apenas da distância do fogo, como apontado na Fig. 2.2a.

Figura 2.2 - Taxa de aquecimento interno do concreto: (a) regressão linear; (b) valores de taxa de aquecimento
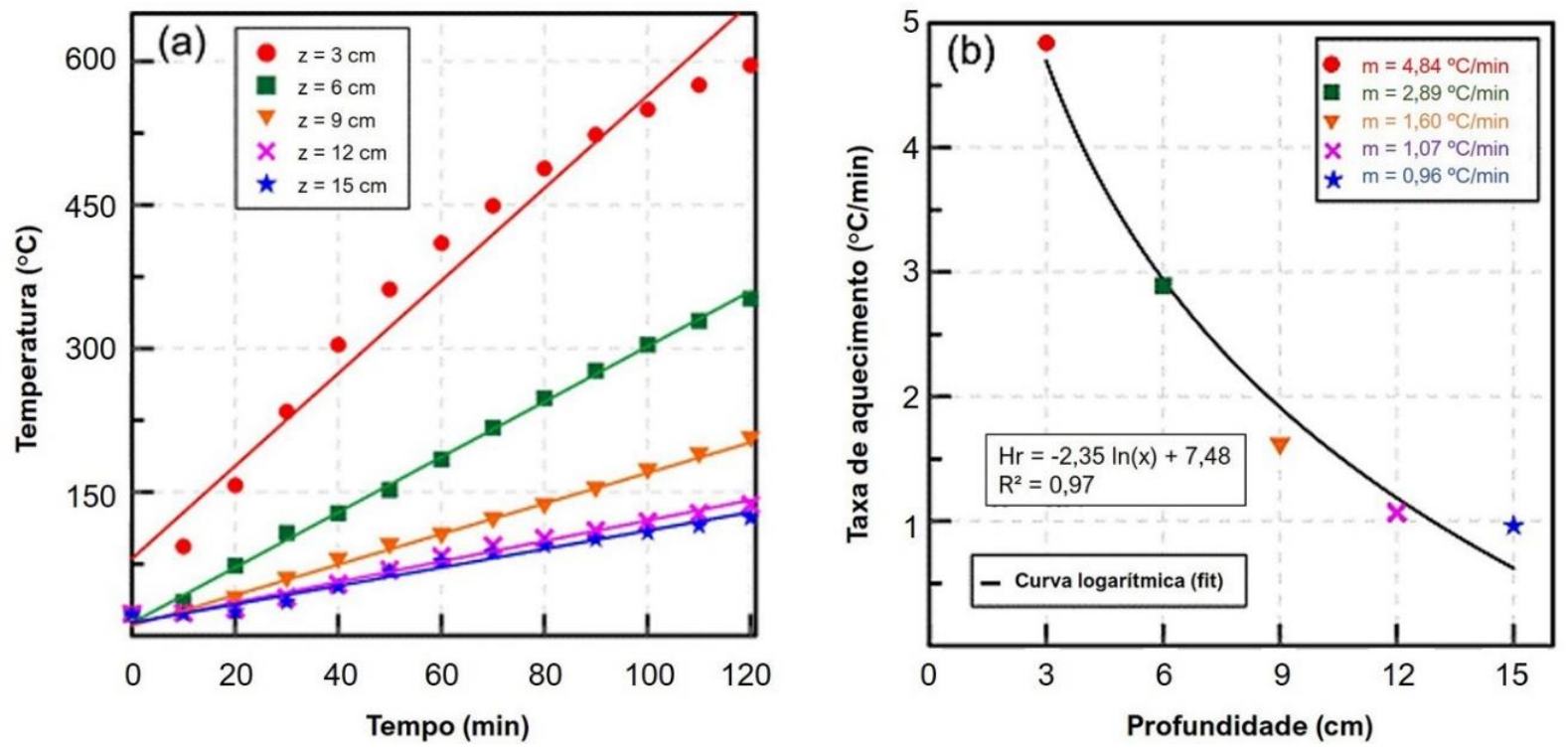

Fonte: adaptado de Serafini et al. (2019a)

Notou-se ainda que os valores de gradiente de temperatura tendem a aumentar de forma quase linear com a duração do incêndio e reduzir em função da distância da face afetada diretamente pelo fogo. A baixa condutividade térmica do concreto é um dos principais fatores associados ao aumento do gradiente de temperatura em função do tempo. À medida que o gradiente de temperatura no concreto aumenta, as tensões de origem térmica provocam danos na forma de fissuras no compósito. Isto reforça a necessidade de controle do lascamento explosivo a partir de uma proteção passiva, de modo a garantir a integridade do revestimento e uma capacidade resistente residual do conjunto que garanta a estabilidade da estrutura.

\subsubsection{Influência das fibras no fenômeno de lascamento explosivo}

O concreto de alta resistência (CAR), frequentemente empregado em aduelas pré-moldadas de túneis, é mais sensível ao fenômeno de lascamento explosivo (spalling) devido à alta densidade de sua matriz e sua baixa permeabilidade (YERMAK et al., 2017). Essa sensibilidade térmica está relacionada com o acúmulo de pressão de vapor de água nos poros durante o 
aquecimento, associado a dificuldade de mobilidade e dissipação da pressão e com mecanismos de dilatação térmica (ULM et al., 1999). Esse fenômeno de desagregação da macroestrutura do concreto submetido a temperaturas elevadas pode apresentar comportamento imprevisível, visto que também pode ser função de muitos fatores, tais como velocidade de aquecimento, teor de umidade, porosidade, idade e esbeltez dos elementos estruturais (COSTA et al., 2002).

A preocupação com o spalling foi posta em questão após o incêndio que ocorreu no Eurotúnel, que produziu forte lascamento explosivo do revestimento de concreto. Este fenômeno pode ser evitado com a utilização de fibras de polipropileno (PP), aplicadas frequentemente nesta situação onde o reforço da matriz não é o principal objetivo. Assim, este tipo de problema deve ser prevenido para minimizar os danos causados pelo fogo ao concreto, permitindo que o material se mantenha íntegro, apesar de degradado, e evitando que as fibras de aço sejam afetadas pelas elevadas temperaturas. No entanto, a eficácia da fibra é muito dependente da resistência da matriz e da sua condição de saturação ou o uso de adições (NINCE et al., 2003; NINCE, 2007).

De acordo com alguns autores (BAZANT, 1997; KALIFA, 2001; NOUMOWÉ, 2005; ZEIML et al., 2006) a probabilidade de ocorrer lascamentos do concreto exposto a elevadas temperaturas diminui com a adição de microfibras de PP em um teor de $0,5 \mathrm{~kg} / \mathrm{m}^{3}$ a $3 \mathrm{~kg} / \mathrm{m}^{3}$. Os processos de fusão e vaporização das fibras de PP, nas temperaturas aproximadas de 170 e $340^{\circ} \mathrm{C}$, respectivamente, aumentam a porosidade e a permeabilidade, além de que geram zonas de transição interfacial adicionais entre as fibras e a pasta de cimento.

Em relação às fibras de aço, estudos conduzidos por Chen e Liu (2004) indicam que o aumento do teor apenas atrasa o tempo de ocorrência do lascamento em concreto de alta resistência. Na ausência de spalling, as propriedades residuais do CRF podem ser determinadas e, uma caracterização cuidadosa do elemento afetado pela temperatura é imprescindível para avaliar sua segurança e definir a estratégia a ser tomada. Logo, deve-se garantir que não haja spalling para que as propriedades do concreto sejam alteradas em função do gradiente de temperatura, para que assim, seja possível considerar a variação do comportamento da matriz e das resistências residuais do compósito.

\subsubsection{Alterações físico-químicas na microestrutura do CRF}

A elevação da temperatura provoca alterações microestruturais na matriz cimentícia, na zona de transição entre a matriz e as fibras e na própria fibra. Essas alterações podem gerar fissuração excessiva, perda de aderência entre a pasta, os agregados e as fibras e, 
consequentemente, afetam as propriedades mecânicas do compósito, com redução da resistência mecânica (TAYLOR, 1997).

Em relação à matriz cimentícia, as alterações na composição química e na microestrutura que se manifestam com o aumento da temperatura são semelhantes àquelas encontradas em concreto simples, sem adição de fibras. De forma resumida, os principais produtos da pasta de cimento que desidratam são: a etringita $\left(\sim 100{ }^{\circ} \mathrm{C}\right)$, acompanhada do monossulfato (entre $~ 50$ e $800{ }^{\circ} \mathrm{C}$ ), portlandita $\left(\sim 450{ }^{\circ} \mathrm{C}\right.$ ) e o silicato de cálcio hidratado (entre 50 e $\sim 600{ }^{\circ} \mathrm{C}$ ). A partir de $600{ }^{\circ} \mathrm{C}$ também inicia o processo de decomposição do carbonato de cálcio na forma de calcita. Devido à desidratação do C-S-H, em temperaturas superiores a $800{ }^{\circ} \mathrm{C}$, verifica-se formação de wollastonita, larnita, merwinita e melilita (MA et al., 2015).

Em termos de expansão térmica, a matriz cimentícia expande até $150{ }^{\circ} \mathrm{C}$, onde a partir desse ponto atinge um período de estabilização até $300{ }^{\circ} \mathrm{C}$. Após esse período, ela começa a retrair até $800^{\circ} \mathrm{C}$. A incompatibilidade em termos de expansão térmica entre a pasta de cimento e os agregados resulta no surgimento de tensões que levam à formação de microfissuras na zona de transição entre os agregados e a matriz cimentícia. Além disso, no agregado, o processo de transição cristalina do $\alpha$-quartzo (trigonal) para $\beta$-quartzo (hexagonal) em torno de $573{ }^{\circ} \mathrm{C}$, associados com eventos de expansão-retração (MA et al., 2015), também podem causar fissuras na matriz e no próprio agregado, afetando as propriedades mecânicas globais do CRF.

O comportamento pós-fissuração do CRF está vinculado com a integridade das fibras e suas respectivas propriedades mecânicas. Logo, é de suma importância parametrizar o grau de dano dessas fibras em função da temperatura no interior do concreto, uma vez que em altas temperaturas, o processo de recristalização afeta suas propriedades mecânicas, alterando seu comportamento mediante esforços de tração (SERAFINI et al., 2018; SERAFINI et al., 2020a). Fibras de aço encruado podem perder encruamento com a exposição a elevadas temperaturas, afetando diretamente o comportamento à tração pós-fissuração do CRF.

Os processos de oxidação e corrosão das fibras de aço iniciam em 500 e $700{ }^{\circ} \mathrm{C}$, respectivamente. Durante o processo de oxidação, há formação de uma camada composta por óxido ferroso $(\mathrm{FeO})$, hematita $\left(\mathrm{Fe}_{2} \mathrm{O}_{3}\right)$ e magnetita $\left(\mathrm{Fe}_{3} \mathrm{O}_{4}\right)$ na superfície das fibras. A formação de óxido gera um aumento em termos de diâmetro externo total e em termos de valores de massa, entretanto a área efetiva de seção transversal das fibras apresenta tendência de redução. Somado a isto, o aço passa pelo processo de recristalização em torno de $450{ }^{\circ} \mathrm{C}$, que consiste na formação de um novo conjunto de grãos livres com aumento significativo no tamanho, 
apresentando baixas densidades. Assim, as fibras de aço expostas a elevadas temperaturas se tornam friáveis, facilmente danificadas (SERAFINI et al., 2020a) e apresentam reduções de resistência à tração próximas de $50 \%$ e $90 \%$ em 400 e $650{ }^{\circ} \mathrm{C}$, respectivamente, de modo que passam a não contribuir de forma efetiva no comportamento pós-fissuração do CRF.

A exposição à temperatura também pode influenciar a interação entre as fibras de aço e a matriz cimentícia. A elevação da temperatura provoca perda de ancoragem da fibra por degradação da matriz de cimento em seu entorno, entretanto o mecanismo de arrancamento das fibras de aço com gancho nas extremidades não é afetado de forma significativa até $\sim 450{ }^{\circ} \mathrm{C}$ (ABDALLAH et al., 2017; RUANO et al., 2018; SERAFINI et al., 2021), o que pode preservar a resistência à tração pós-fissuração do CRF até esta temperatura.

\subsubsection{Propriedades mecânicas associadas à matriz}

Em geral, ao utilizar baixos teores de fibras de aço, o comportamento da matriz de concreto do CRF sofre alterações com a temperatura de maneira similar àquelas verificadas para o concreto simples. Alguns estudos (YERMAK et al., 2017; POON et al., 2004; TAI et al., 2011) revelam que em concretos com adição de até $70 \mathrm{~kg} / \mathrm{m}^{3}$ de fibras de aço (menor que 0,90\% em volume) há perdas de resistência à compressão que chegam a 40\% e 70\% após aquecimento a 400 e $600^{\circ} \mathrm{C}$, respectivamente, em relação à temperatura ambiente.

Alguns estudos indicam que podem existir alterações no comportamento mecânico da matriz após exposição a elevadas temperaturas quando se utilizam teores de fibras de aço próximos ou acima de 1\%. Estudos realizados por Chan et al. (2000) em concreto de alta resistência (com $1 \%$ de fibras de aço em volume; ciclo único a $800{ }^{\circ} \mathrm{C}, \Delta \mathrm{T} / \Delta \mathrm{t}=5-7{ }^{\circ} \mathrm{C} / \mathrm{min}$ ) mostraram que a utilização de teores elevados de fibras contribuiu para a manutenção da resistência à compressão residual (pós-temperatura), reduzindo a taxa de degradação nessa propriedade. Esse efeito favorável ocasionado pela utilização de fibras de aço também foi constatado no estudo de Felicetti et al. (2000), que utilizou um teor elevado ( $2 \%$ em volume) se for considerada a aplicação em aduelas para TBM. Após aquecimento a $600{ }^{\circ} \mathrm{C}$, o CRFA retinha $65 \%$ da sua resistência à compressão inicial, enquanto o concreto sem fibras apenas $44 \%$.

As reduções na propriedade de resistência à compressão do CRF após exposição a elevadas temperaturas estão intimamente relacionadas com os fatores discutidos na Seção 2.3.3, os quais se destacam a decomposição dos produtos de hidratação em uma ampla faixa de temperatura e à incompatibilidade térmica entre o agregado e a pasta, induzindo fissuras em sua interface 
(YERMAK et al., 2017; XING et al., 2015). No entanto, o uso de teores elevados de fibras de aço reduz a taxa de degradação dessa propriedade, embora à $900^{\circ} \mathrm{C}$ sua contribuição mecânica para o concreto seja mínima ou nula.

A redução nos valores de módulo de elasticidade com a elevação da temperatura ocorre de forma mais intensa quando comparada à resistência a compressão e independe do teor de fibra de aço empregado, pois tem relação direta com a redução no volume de sólidos da pasta de cimento e o aumento da porosidade do compósito, principalmente entre a faixa compreendida entre 150 e $450{ }^{\circ} \mathrm{C} . \mathrm{Em} 400$ e $600^{\circ} \mathrm{C}$ as reduções em termos de módulo, quando comparado à temperatura ambiente, ultrapassam 60\% e 80\%, respectivamente (SERAFINI et al., 2018).

Entretanto, entre as propriedades mecânicas do concreto, a resistência à tração apresenta o comportamento mais sensível à temperatura (FIB, 2008), como demonstrado na Figura 2.3. De forma geral, após o resfriamento e em relação ao concreto aquecido, a resistência à tração é maior para concreto com sílica ativa; decresce rapidamente com a temperatura em concreto de alto desempenho (principalmente para $\mathrm{T} \geq 600^{\circ} \mathrm{C}$ ); é pouco afetada pelo tipo de resfriamento (lento e controlado no forno ou rápido na água); e é próxima da resistência a quente em concreto de alta resistência com sílica ativa (FIB, 2008). No entanto, esta condição de variação comportamental está associada à garantia de que não haja lascamento explosivo, o que deve ser controlado por metodologia específica. Caso contrário, não haverá material e propriedades residuais do compósito.

Figura 2.3 - Redução da densidade e resistências à compressão e à tração do concreto em função da temperatura

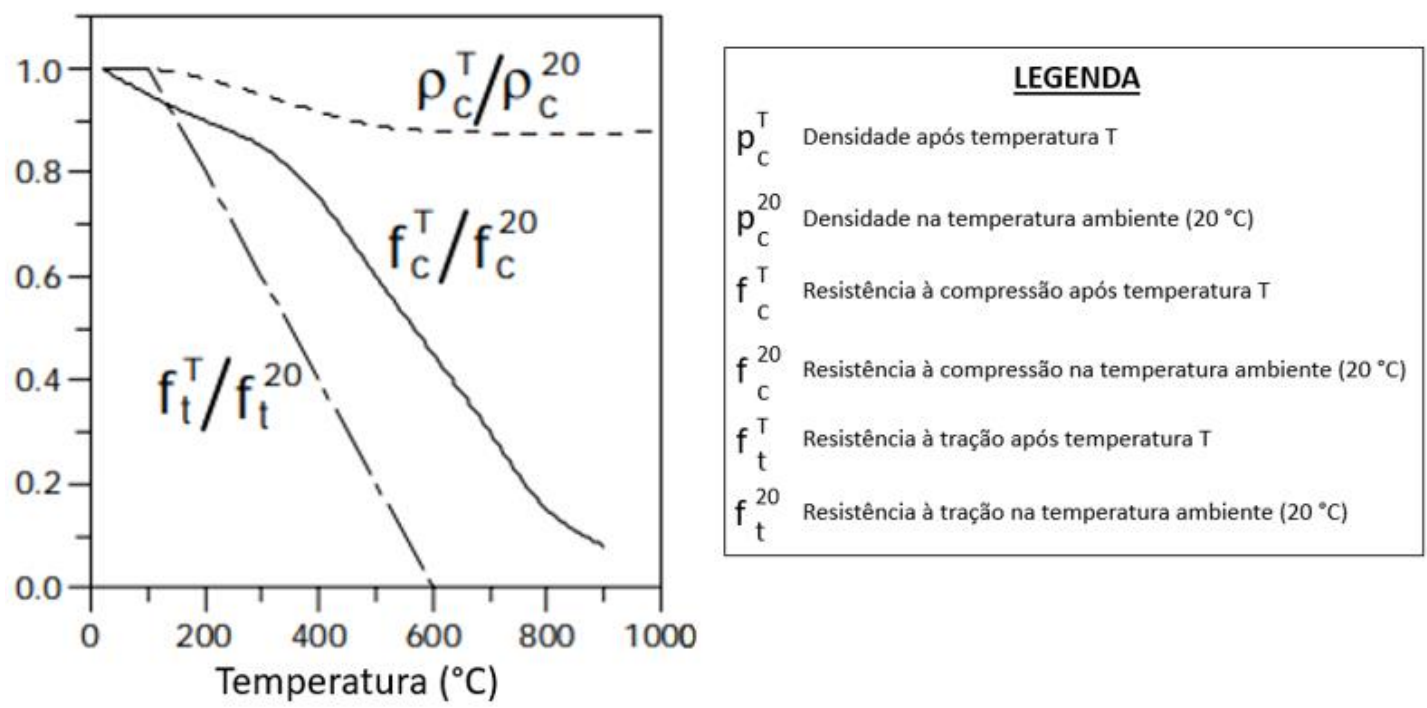

Fonte: adaptado de FIB (2008) 


\subsubsection{Comportamento pós-fỉssuração}

Quando o CRF é submetido a elevadas temperaturas, a principal preocupação é quanto à sua resistência à tração pós-fissuração, que pode ser severamente afetada em temperaturas acima de $300^{\circ} \mathrm{C}$, principalmente em razão da degradação das fibras (SUKONTASUKKUL et al., 2010). O comportamento pós-fissuração do CRF, quando submetido a elevadas temperaturas, varia conforme o tipo e o teor de fibra, a temperatura e o tempo de exposição. Os ensaios utilizados na avaliação pós-temperatura, assim como a verificação da técnica mais efetiva para este fim, são discutidos na Seção 2.4, o que também é parte importante deste estudo.

Yermak et al. (2017) verificaram que a resistência à tração pós-fissuração do CRF apresenta diminuição lenta até $300{ }^{\circ} \mathrm{C}$, onde a partir desse ponto, os efeitos do aumento da temperatura são mais significativos. Comparado ao concreto simples, a adição de fibras de aço acarretou aumento de $\sim 10 \%$ na resistência à tração pós-fissuração após exposição a 300 e $600{ }^{\circ} \mathrm{C}$, onde a partir de $750{ }^{\circ} \mathrm{C}$ não apresentaram capacidade de contribuir na manutenção desta propriedade.

As propriedades mecânicas do CRFP $\left(8 \mathrm{~kg} / \mathrm{m}^{3}\right.$ de macrofibras poliméricas) exposto a elevadas temperaturas foram avaliadas em estudo conduzido por Rambo et al. (2018). Utilizouse forno elétrico para realizar o procedimento de aquecimento das amostras, com exposição até $600{ }^{\circ} \mathrm{C}$. Notou-se que a resistência à tração do CRFP reduziu gradualmente e a resposta pósfissuração variou significativamente com a elevação da temperatura (Figura 2.4). O efeito da temperatura não foi significativo até $200{ }^{\circ} \mathrm{C}$, entretanto a partir de $400{ }^{\circ} \mathrm{C}$ a resistência à tração pós-fissuração reduziu significativamente $(\sim 54 \%)$ em relação à temperatura ambiente.

Serafini et al. (2019a) avaliaram o comportamento à tração de amostras prismáticas de CRFP ( $8 \mathrm{~kg} / \mathrm{m}^{3}$ de macrofibras poliméricas) submetidas ao ensaio de exposição unifacial ao fogo. Os resultados e as curvas obtidas por meio do ensaio de flexão adotado (Figura 2.5) demonstram que os valores de resistência à tração da matriz cimentícia reduziram $97 \%$ em relação à temperatura ambiente, o que está associado com a decomposição dos produtos de hidratação da pasta de cimento, redução da área específica dos hidratos e aumento no volume total de poros na pasta de cimento, como apresentado na Seção 2.3.3. Reduções apresentadas nos valores de resistência à tração pós-fissuração associados ao estado limite de serviço (ELS) e ao estado limite último (ELU) - em torno de $85 \%$ e 95\%, respectivamente - estão relacionadas principalmente com a degradação das fibras na região de tração das amostras, especialmente nos primeiros $12 \mathrm{~cm}$ a partir da face mais próxima da chama. 
Figura 2.4 - Curvas tensão-deformação obtidas por meio do ensaio de Duplo Puncionamento de corpos de prova de CRFP submetidos a diferentes temperaturas
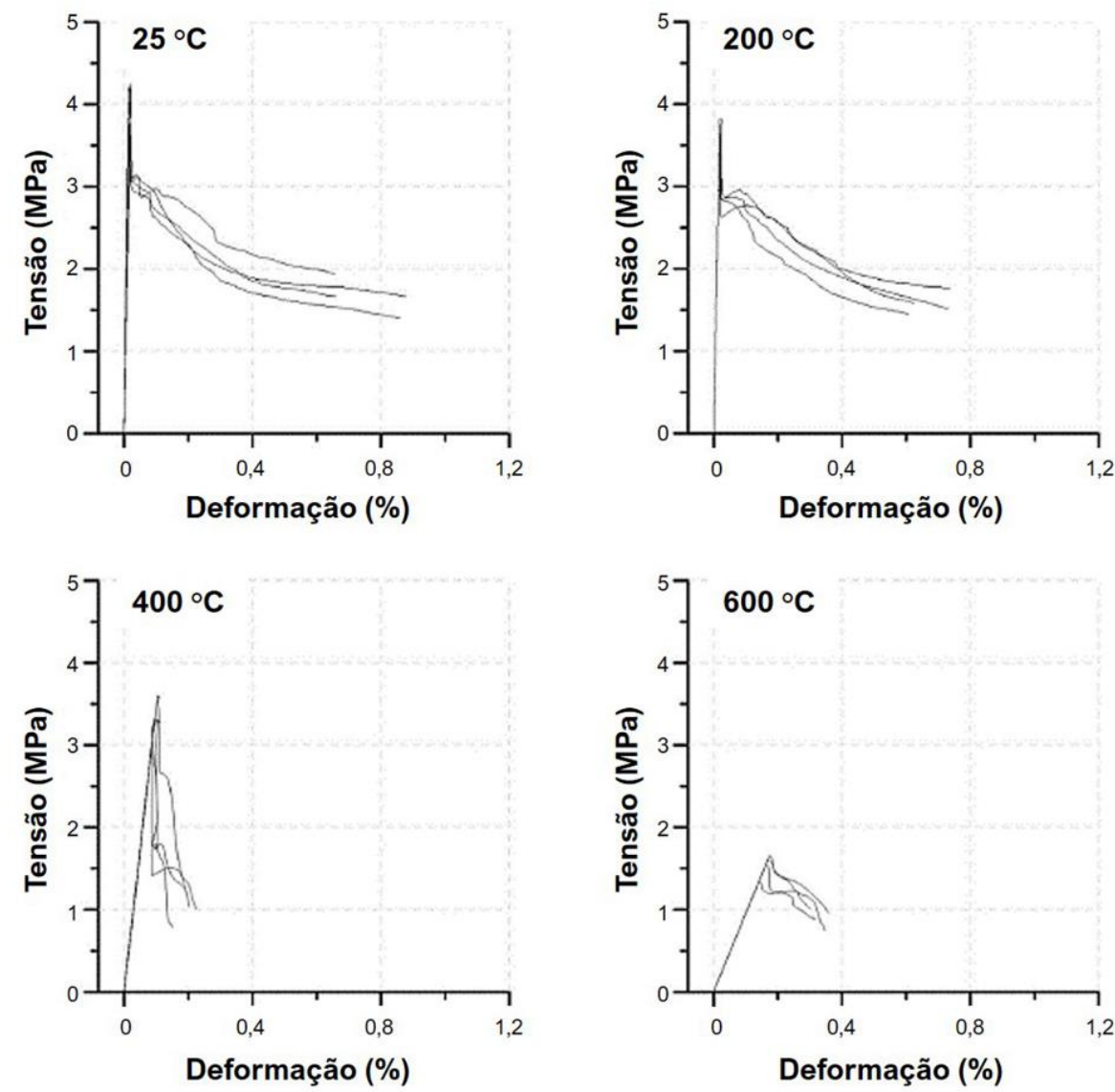

Fonte: adaptado de Rambo et al. (2018)

Figura 2.5 - Curvas Carga versus CMOD de ensaio de flexão para o CRFP antes e após exposição ao fogo

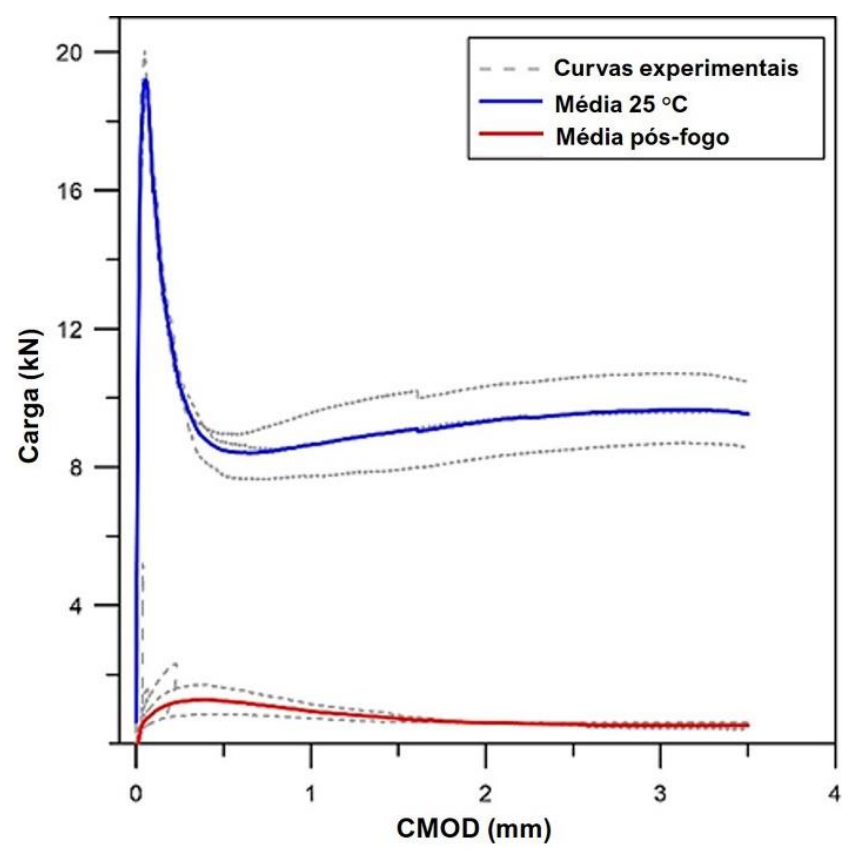

Fonte: adaptado de Serafini et al. (2019a) 
Agra et al. (2019) avaliaram o comportamento à tração do CRFA $\left(35 \mathrm{~kg} / \mathrm{m}^{3}\right.$ de fibras de aço) submetido ao ensaio de exposição unifacial ao fogo. Os resultados demonstram que os valores de resistência à tração da matriz cimentícia após exposição ao fogo foram, em média, $71 \%$ menores que os obtidos em temperatura ambiente, o que está associado principalmente à desidratação de produtos da pasta de cimento, como demonstrado na Seção 2.3.3. Já os valores de resistência à tração pós-fissuração associados ao ELS e ao ELU foram, em média, 64\% e $60 \%$ menores que os obtidos em temperatura ambiente (Figura 2.6). Esses efeitos estão relacionados com a perda de capacidade de reforço das fibras em razão da sua degradação e alterações na zona de transição com a matriz.

As propriedades mecânicas do CRFA exposto a elevadas temperaturas também foram investigadas em estudo conduzido por Serafini et al. (2019b). Utilizou-se forno elétrico para realizar o procedimento de aquecimento, com exposição das amostras até $600{ }^{\circ} \mathrm{C}$. Notou-se que a resistência à tração do CRFA (35 kg/m³ de fibras de aço) e a resistência à tração pós-fissuração associadas ao ELS e ao ELU são significativamente afetadas. Os valores de resistência à tração da matriz cimentícia, após exposição a $600{ }^{\circ} \mathrm{C}$ foram, em média, $83 \%$ menores que os obtidos em temperatura ambiente. Já os valores de resistência à tração pós-fissuração associados ao ELS e ao ELU foram, em média, $73 \%$ menores que os obtidos em temperatura ambiente.

Figura 2.6 - Curvas de resistência à tração média por abertura de fissura (COD) do CRFA na temperatura ambiente e após exposição ao fogo

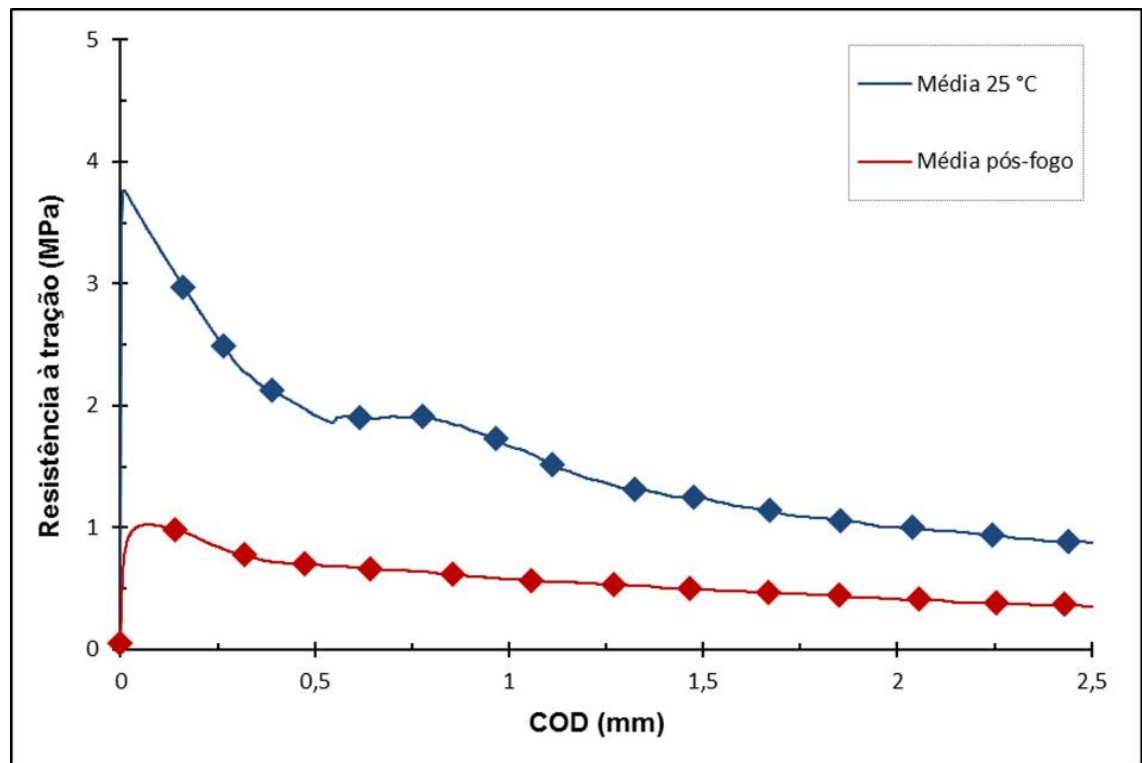

Fonte: adaptado de Agra et al. (2019) 
Os trabalhos apresentados nesta seção (YERMAK et al., 2017; RAMBO et al., 2018; SERAFINI et al., 2019a; AGRA et al., 2019) evidenciam o efeito significativo das temperaturas elevadas na resistência à tração pós-fissuração do CRF. Devido à degradação das fibras e considerando que sua maior contribuição ocorre no estágio pós-fissuração, torna-se imprescindível a parametrização do comportamento do CRF submetido a elevadas temperaturas a partir da variação do teor de fibra de aço, a fim de ter uma análise completa. Essa verificação é importante e deve ser levada em conta para auxiliar o projetista, a fim de garantir a segurança de aduelas pré-moldadas de CRF no revestimento de túneis.

No entanto, as metodologias empregadas nesses trabalhos para avaliação das propriedades de tração e os procedimentos de aquecimento são distintos entre os estudos, o que acaba dificultando sua comparação, uma vez que cada ensaio apresenta uma resposta própria. Apesar de existir uma evolução na metodologia de ensaios utilizada para a verificação da influência da alta temperatura no comportamento do CRF, ainda não há técnica suficientemente desenvolvida e eficaz para este fim, em razão dos aspectos que são discutidos na Seção seguinte.

Estudos que comparam técnicas distintas de avaliação das propriedades de tração do CRFA submetido a elevadas temperaturas são escassos na literatura, especialmente quando o procedimento de aquecimento consiste na exposição unifacial das amostras ao fogo ou por meio de taxas elevadas de aquecimento em forno elétrico, a fim de simular a agressividade do incêndio em túneis, o que é parte importante deste trabalho. Muitos desses estudos comparativos são restritos à temperatura ambiente, o que evidencia a lacuna científica na área de elevadas temperaturas.

Ressalta-se ainda que a espessura das aduelas de CRF está acima dos $15 \mathrm{~cm}$ utilizados na maioria das análises laboratoriais e as solicitações em serviço são menores que as transitórias. Assim, mesmo se houver deterioração significativa do material na face exposta ao fogo, isso não significa necessariamente a perda das condições de estabilidade do revestimento do túnel, visto que há possibilidade de as camadas interiores fornecerem condições de suporte suficientes (SERAFINI et al., 2019a). Isto se deve ao fato de o dimensionamento dos segmentos estar correlacionado a condições transitórias que podem ser as críticas no dimensionamento, tais como o empuxo dos atuadores, o que faz com que as condições de serviço sejam atendidas com grande margem de segurança na grande maioria dos casos. 


\subsection{Técnicas de caracterização do CRF submetido a elevadas temperaturas}

\subsubsection{Técnicas de caracterização das propriedades de tração}

Verificações experimentais do ponto de vista estrutural são sugeridas com o propósito de conhecer o comportamento do CRF sob condições de elevadas temperaturas, visto que ainda não há abordagem adequada de projeto em situação de incêndio. Atualmente há grande dificuldade de previsão do comportamento estrutural para o CRF em caso de incêndio, o que explica a limitação de parâmetros na literatura (DEHN; HERRMANN, 2017). Por essa razão, tem sido frequente a realização de alguns estudos de homologação ou de avaliação em escala real para verificação direta do comportamento estrutural, o que apresenta grande dificuldade de realização na condição de um túnel. Isto também revela a necessidade de ensaios de mesoescala para obter respostas das propriedades mecânicas do compósito exposto a elevadas temperaturas.

É possível realizar a avaliação do comportamento estrutural do CRF durante e após o incêndio. Realizar a avaliação durante o aquecimento exige condições laboratoriais específicas, especialmente quando se trata dos equipamentos de ensaio, muitas vezes inviabilizados pelo custo elevado. Por essa razão, boa parte dos resultados encontrados na literatura são obtidos em condições residuais, isto é, após o resfriamento das amostras. Com a temperatura ambiente reestabelecida, o processo de instrumentação das amostras não apresenta grandes dificuldades após aquecimento até aproximadamente $450{ }^{\circ} \mathrm{C}$.

Sabe-se que no CAR com sílica ativa em sua composição a resistência à tração após exposição à temperatura é próxima da obtida durante o aquecimento (FIB, 2008). No entanto, no ambiente de um túnel, o aumento da temperatura provoca expansão térmica do revestimento de concreto, o qual é carregado por tensões devido à pressão do solo (LILLIU; MEDA, 2013). Mesmo com a integridade afetada pela elevação da temperatura, o CRF ainda mantém parte da sua capacidade resistente, o que torna essencial o conhecimento das propriedades residuais do compósito. Porém, deve-se atentar para os riscos durante o resfriamento do CRF, os quais estão associados ao surgimento de deformações pós-incêndio, o que torna esta condição crítica em termos de avaliação mecânica, configurando-se assim a favor da segurança.

Para a caracterização mecânica do CRF do ponto de vista estrutural é necessário considerar o comportamento pós-pico da curva força versus deformação na tração, com a determinação da resistência pós-fissuração do compósito (FIB, 2013). Esta avaliação é tradicionalmente realizada por meio de ensaios de flexão de corpos de prova prismáticos com entalhe. Para os 
ensaios mecânicos realizados após exposição a elevadas temperaturas, os entalhes devem ser razoavelmente grandes, uma vez que as microfissuras induzidas pela temperatura podem impedir que a fissura se localize na região do plano do entalhe (FELICETTI et al., 2000). Além disso, as condições de temperatura e umidade no interior das amostras devem ser tão uniformes quanto possível durante os processos de aquecimento e resfriamento, visto que estes são os parâmetros que controlam a maior parte dos processos químicos e físicos e, consequentemente, as alterações das propriedades mecânicas do concreto (FERNANDES et al., 2017).

O ensaio preconizado pela EN 14651 (2007) já foi utilizado (Figura 2.7) para a avaliação da resistência à tração na flexão do CRF exposto ao fogo, em aquecimento unifacial das amostras a temperaturas de até $1100^{\circ} \mathrm{C}$ por 120 minutos, reproduzindo a curva "H" (SERAFINI et al., 2019a). Entretanto, as dificuldades experimentais de realização do ensaio são grandes em função das dimensões dos prismas $(550 \times 150 \times 150 \mathrm{~mm})$, da dificuldade de manuseio dos mesmos e da fragilidade das amostras após exposição ao fogo. Ressalta-se que o contato dos cutelos com as amostras deterioradas pela elevada temperatura pode gerar deformações plásticas localizadas que podem levar a distorções dos resultados. Além disso, há uma superestimativa dos valores de resistência à tração quando da utilização deste ensaio, o que pode gerar dúvidas sobre o emprego de fatores de conversão entre valores de resistência à tração na flexão e resistência à tração direta.

Assim, novas metodologias têm sido utilizadas em substituição aos ensaios de flexão para avaliação do CRF quanto à resistência à tração pós-fissuração, dentre elas: o ensaio de Duplo Puncionamento (DPT) e o ensaio Double Edge Wedge Splitting (DEWS) (CHOUMANIDIS et al., 2017; UNE, 2010; di PRISCO et al., 2013).

Figura 2.7 - Amostra exposta ao fogo e submetida ao ensaio de flexão da EN 14651

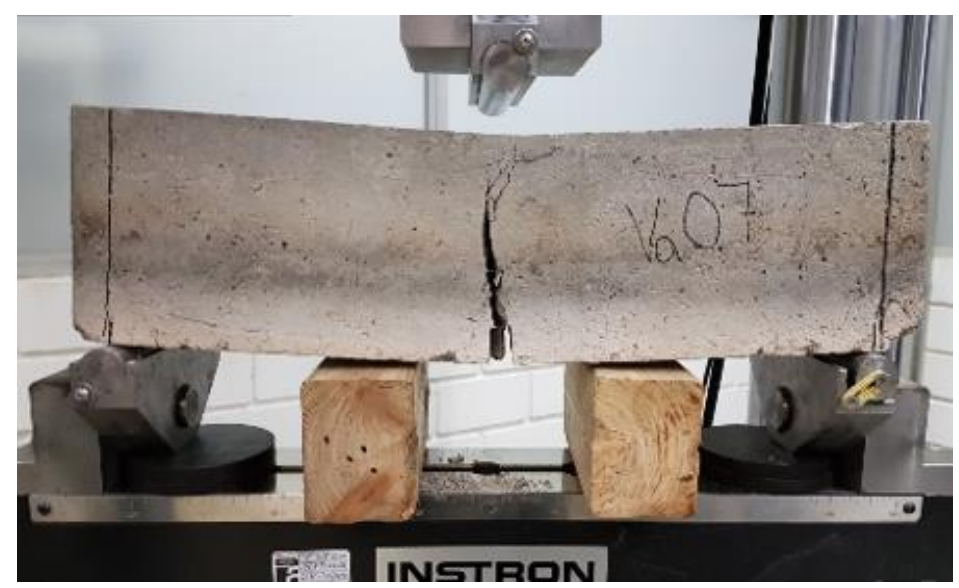

Fonte: Serafini et al. (2019a) 
O ensaio DPT apresenta uma série de vantagens, como facilidade de execução, simplicidade de preparação das amostras e baixa variabilidade dos resultados (MOLINS et al., 2008). Particularmente, as propriedades do CRF podem ser determinadas em amostras cilíndricas relativamente pequenas, que podem ser moldadas ou extraídas de estruturas existentes. Para aplicação da metodologia simplificada (PUJADAS, 2013), acessível na maioria dos laboratórios, é necessária uma máquina de ensaio à compressão convencional, equipada com controle de deslocamento axial (não necessariamente com sistema fechado de controle). $\mathrm{O}$ DPT possui correlações com o ensaio EN 14651 (2007) e permite detectar alterações das características do CRF frente às influências de parâmetros que determinam o comportamento mecânico do compósito, como alterações em razão da variação do teor de fibras (GALOBARDES; FIGUEIREDO, 2015).

Um dos obstáculos para a utilização do DPT como técnica definitiva de avaliação pósfissuração do CRF é a dificuldade de determinação das equações constitutivas de tensãodeformação, principalmente devido à imprevisibilidade do número de planos de fratura (di PRISCO et al., 2013). No entanto, o DPT é um dos poucos ensaios que pode ser realizado em amostras de CRF extraídas de estruturas que foram expostas ao fogo (RAMBO et al., 2018). O DPT também tem sido aplicado a fim de investigar as propriedades mecânicas do CRF exposto a elevadas temperaturas, mostrando que o teor e o fator de forma das fibras constituem fatores mais prejudiciais ao comportamento de tração do CRF do que o tipo de fibra (KIM et al., 2015).

Rambo et. al (2018) investigaram as propriedades mecânicas de amostras de CRFP expostas a temperaturas de até $600{ }^{\circ} \mathrm{C}$ e a aplicabilidade do ensaio DPT para avaliar a resistência à tração residual. Como consequência da degradação sofrida pela superfície da amostra, somada à punção que resulta no esmagamento da matriz deteriorada, o ensaio DPT não apresentou resposta conclusiva após exposição a altas temperaturas, principalmente porque o efeito de atrito adicional gerado pela interação de punção entre a matriz e o pistão pode ser confundido com o efeito de ponte proporcionado pelas fibras. Apesar disso, o gradiente de temperatura estabelecido nas amostras pode ter preservado parte do material e, consequentemente, uma parcela da resistência residual do compósito.

O ensaio DEWS constitui um ensaio de tração indireta por meio da aplicação de esforços de compressão em um corpo de prova com cunhas e entalhes em duas faces opostas (di PRISCO et al., 2013). Trata-se de um ensaio que pode ser realizado em pequenas amostras cúbicas, extraídas de estruturas afetadas pelo fogo ou de corpos de prova de maiores dimensões, além 
de ser executado em sistema de controle aberto (open-loop), o que viabiliza sua aplicação em grande parte dos laboratórios. Uma fratura tipo I é obtida por meio do ensaio DEWS, permitindo assim, a obtenção direta dos valores de resistência à tração associados a níveis de fissuração do compósito, o que é fundamentalmente importante para avaliação de segurança estrutural, a partir da investigação de sua capacidade resistente, em concordância com o fib Model Code.

Borges et al. (2019) concluíram que algumas limitações devem ser observadas, tais como a presença de uma região instável pós-pico, especialmente quando a lacuna entre a resistência à tração da matriz e a resistência à tração pós-fissuração associada ao ELS for elevada. Isso pode ocorrer quando um teor baixo de fibra de aço é empregado ou quando se utiliza sistema aberto de controle de velocidade durante o ensaio. Agra et al. (2019) evidenciaram que o ensaio DEWS é capaz de caracterizar o CRFA quanto à resistência à tração residual mesmo em condições severas, como no caso de amostras submetidas à ação do fogo. Isso foi possível porque a avaliação ocorreu sem haver prejuízos aos valores obtidos como resposta do material, visto que não foram constatados danos no concreto na região de contato com os roletes.

Estudos que correlacionam respostas de ensaios distintos são frequentemente realizados em amostras de CRF na temperatura ambiente, porém pouco empregados nas condições de elevação de temperatura. Neste trabalho de dissertação foram escolhidos dois métodos para avaliar o CRF exposto a elevadas temperaturas: os ensaios de flexão e DEWS. A razão dessa escolha se deve ao fato do DPT já ter se apresentado inviável em condições específicas de avaliação pós-temperatura, visto que é um ensaio que atua por compressão e pode apresentar esmagamento localizado no ponto de aplicação da força, uma vez que as amostras expostas a elevadas temperaturas se apresentam deterioradas.

O ensaio de flexão em prismas preconizado pela EN 14651 (2007) apesar de ser um ensaio mais pesado e, ao mesmo tempo, mais delicado e susceptível a prejuízos de manipulação em amostras deterioradas pela temperatura elevada, é comumente adotado para avaliação do comportamento do CRF, inclusive recomendado pelo fib Model Code (2013). Realizá-lo de forma adaptada, em amostras de dimensões menores, como no caso deste estudo, pode configurar uma alternativa aplicável. Nas condições de avaliação pós-temperatura, o DEWS surge como proposta viável para teores baixos de fibras, no entanto ainda necessita de estudos para consolidá-lo, especialmente com a variação do teor de fibra. Procurar estabelecer relações entre esses dois ensaios pode fornecer contribuições importantes para a caracterização das propriedades de tração do CRF submetido a elevadas temperaturas, especialmente para o comportamento pós-fissuração. 


\subsubsection{Avaliação por meio de técnicas não destrutivas}

A avaliação da capacidade residual do CRF exposto ao fogo é uma tarefa difícil, visto que as técnicas tradicionais de ensaios não destrutivos, de forma geral, não são adequadas para a verificação de um material com características heterogêneas. As possíveis abordagens para este problema geralmente envolvem a avaliação da resposta média do material ou uma análise ponto a ponto de pequenas amostras extraídas do compósito afetado. A combinação de técnicas é constantemente aplicada nesta análise, o que permite investigar e mensurar alterações físicas, químicas e mineralógicas (FERNANDES et al., 2017). Além disso, essas técnicas devem ser aplicadas em conjunto com os ensaios de caracterização mecânica, visto que podem fornecer suporte às análises das propriedades mecânicas, a fim de obter uma completa avaliação do material após exposição a elevadas temperaturas. Uma síntese das técnicas não destrutivas usualmente empregadas nas amostras de CRF é apresentada na Tabela 2.1.

Tabela 2.1 - Ensaios não destrutivos aplicados às amostras de CRF após exposição a elevadas temperaturas

\begin{tabular}{cc}
$\begin{array}{c}\text { Análise ponto a ponto de } \\
\text { pequenas amostras }\end{array}$ & Técnicas especiais \\
\hline $\begin{array}{c}\text { Análise térmica diferencial } \\
\text { (DTA) }\end{array}$ & $\begin{array}{c}\text { Propagação de pulso } \\
\text { ultrassônico }\end{array}$ \\
$\begin{array}{c}\text { Análise termogravimétrica } \\
\text { (TGA) } \\
\text { Porosimetria e Calorimetria }\end{array}$ & $\begin{array}{c}\text { Análise Modal das Ondas } \\
\text { de Superfície (MASW) }\end{array}$ \\
Análise química & Eco de impacto \\
Difração de Raio-X & Resistividade elétrica \\
Microscopia eletrônica de \\
varredura (MEV)
\end{tabular}

Análises realizadas por meio da técnica de Difração de Raio-X (DRX) em amostras expostas a temperaturas entre 100 e $1000{ }^{\circ} \mathrm{C}$ apresentam redução gradual no teor de portlandita $\left(\mathrm{Ca}(\mathrm{OH})_{2}\right)$ a partir de $400{ }^{\circ} \mathrm{C}$ até a completa extinção aos $800{ }^{\circ} \mathrm{C}$, indicando deterioração gradual da matriz cimentícia (HANDOO et al., 2002). Peng e Huang (2008) constataram que a portlandita e o carbonato de cálcio $\left(\mathrm{CaCO}_{3}\right)$ começaram a se decompor em temperaturas próximas a $500{ }^{\circ} \mathrm{C}$, enquanto o silicato de cálcio hidratado $(\mathrm{C}-\mathrm{S}-\mathrm{H})$ em $600{ }^{\circ} \mathrm{C}$, o que tem 
relação com a presença de poros observados por meio da técnica de Microscopia Eletrônica de Varredura (MEV). Lim e Mondal (2014) observaram o desaparecimento do pico correspondente ao C-S-H, juntamente com o surgimento do pico de $\beta-\mathrm{C}_{2} \mathrm{~S}$, a partir de $500{ }^{\circ} \mathrm{C}$. Em $700{ }^{\circ} \mathrm{C}$ há formação de $\mathrm{CaCO}_{3}$, oriundo da reação do óxido de cálcio $(\mathrm{CaO})$ com o dióxido de carbono $\left(\mathrm{CO}_{2}\right)$ do forno, enquanto em $900{ }^{\circ} \mathrm{C}$ observa-se seu desaparecimento.

Em estudos de exposição de concretos convencionais a elevadas temperaturas, Handoo et al. (2002), por meio da microscopia eletrônica de varredura (MEV), constataram que as alterações morfológicas iniciaram em $300{ }^{\circ} \mathrm{C}$ e se intensificaram em $600{ }^{\circ} \mathrm{C}$, apresentando deformações significativas nos cristais de portlandita $\left(\mathrm{Ca}(\mathrm{OH})_{2}\right)$ e no C-S-H, além da presença de fissuras e vazios interconectados, também identificados por Peng e Huang (2008), o que gerou aumento da porosidade do concreto e redução de sua capacidade resistente. 


\section{PROGRAMA EXPERIMENTAL}

Este capítulo é destinado à apresentação do programa experimental desenvolvido, caracterizando os materiais e equipamentos, abordando a metodologia utilizada na produção dos corpos de prova de CRFA e na execução dos ensaios, nos estados fresco e endurecido, antes e após o aquecimento em elevadas temperaturas. As amostras foram produzidas e ensaiadas nas dependências dos Laboratórios da Escola Politécnica da Universidade de São Paulo (EPUSP) e do Instituto de Pesquisas Tecnológicas do Estado de São Paulo (IPT).

Para avaliar o comportamento mecânico pós-fissuração do CRF, por meio da caracterização da resistência à tração residual, o método utilizado foi o ensaio DEWS de tração indireta, aplicado em amostras com fibras de aço e microfibras de polipropileno (PP), na temperatura ambiente e em diferentes temperaturas de aquecimento. Além do ensaio DEWS, após exposição ao fogo, por meio de uma simulação de incêndio, o ensaio de flexão também foi empregado para avaliação das propriedades de tração pós-fissuração. Além disso, ensaios de resistência à compressão $\left(\mathrm{f}_{\mathrm{c}}\right)$ e módulo de elasticidade $(\mathrm{E})$ foram realizados para caracterizar o compósito de maneira mais ampla e completa, envolvendo as propriedades governadas pela matriz e que são importantes parâmetros para a previsão de comportamento estrutural. A influência da temperatura nas propriedades microestruturais do CRF foi avaliada em amostras de pasta de cimento, seguindo as mesmas proporções do concreto, por meio da técnica de Difração de Raios X (DRX). As etapas executadas são detalhadas em sequência na Figura 3.1.

Figura 3.1 - Esquema adotado para o programa experimental deste estudo

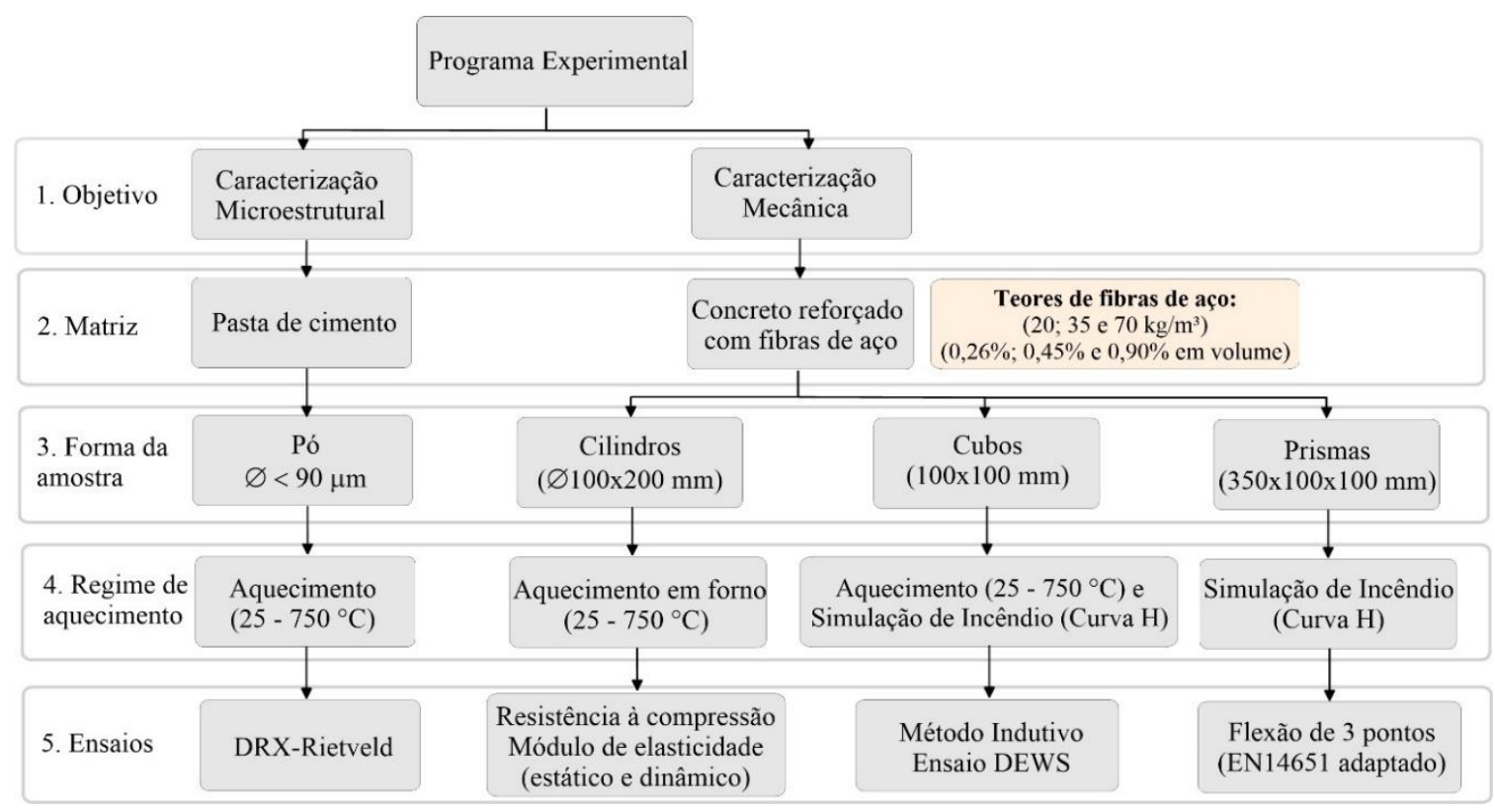

Fonte: Elaborado pelo autor 


\subsection{Materiais}

Os quantitativos de materiais utilizados foram definidos com base em três dosagens previamente elaboradas de concretos de alta resistência (CAR) reforçados com fibras de aço, como a utilizada na construção da Linha 6 do Metrô da cidade de São Paulo, seguindo o critério adotado em estudos anteriores (RAMBO et al., 2018; SERAFINI et al., 2019a), desenvolvidos dentro do grupo de pesquisa, mas que utilizaram apenas um teor fixo de fibras. O principal objetivo desta opção é a utilização de um material de referência associado a uma obra de infraestrutura real a ser executada na cidade de São Paulo, além de poder comparar os resultados com estudos anteriores, dado que a metodologia de avaliação também é foco da análise.

Cimento de alta resistência inicial (CP-V ARI RS, equivalente ao CEM I 52.5R) foi utilizado como ligante na mistura. Como material cimentício suplementar, sílicia ativa (Elkem 920-U) foi utilizada em um teor de 5,5\% da massa de cimento. Areia de rio e artificial foram utilizadas como agregado miúdo. Dois tipos de agregados graúdos artificiais foram utilizados: britas com d dáx: 19 mm e $d_{\text {máx: }}$ 9,5 mm. Os agregados foram peneirados e colocados em estufa a $100{ }^{\circ} \mathrm{C}$ durante $14 \mathrm{~h}$ antes da produção do concreto. Os teores de fibras longas de aço (Dramix 3D 80/60BG) variaram, de forma que foram realizadas moldagens distintas com $20 \mathrm{~kg} / \mathrm{m}^{3}$ $\left(0,26 \%\right.$ em volume), $35 \mathrm{~kg} / \mathrm{m}^{3}\left(0,45 \%\right.$ em volume) e $70 \mathrm{~kg} / \mathrm{m}^{3}(0,9 \%$ em volume $)$. As microfibras de polipropileno (Neomatex FireX) foram utilizadas em um teor fixo de $0,8 \mathrm{~kg} / \mathrm{m}^{3}$ (0,09\% em volume), de modo a prevenir lascamentos explosivos (spalling) no CRF. Também foi utilizado um aditivo superplastificante de última geração (Grace ADVA CAST 525) específico para elementos pré-moldados para dar mobilidade à mistura.

Os agregados utilizados foram caracterizados segundo os métodos especificados nas normas da ABNT para agregados naturais miúdo e graúdo. Na Tabela 3.1 estão apresentados os ensaios e as respectivas normas utilizadas.

Tabela 3.1 - Ensaios e normas utilizados para caracterização dos agregados

\begin{tabular}{ccc}
\hline \multirow{2}{*}{ ENSAIOS } & \multicolumn{2}{c}{ ABR } \\
\cline { 2 - 3 } & Agregado graúdo & Agregado miúdo \\
\hline Granulometria & NM 248 (ABNT, 2003) & NM 248 (ABNT, 2003) \\
Massa unitária & NM 45 (ABNT, 2006) & NM 45 (ABNT, 2006) \\
Massa específica & NM 53 (ABNT, 2003) & NM 30 (ABNT, 2001) \\
Absorção & NM 53 (ABNT, 2003) & NM 52 (ABNT, 2009) \\
\hline
\end{tabular}

Fonte: Elaborado pelo autor 


\subsubsection{Cimento}

Utilizou-se cimento de alta resistência inicial (CP-V ARI RS) como ligante neste estudo, cuja massa específica e área superficial específica foram, respectivamente, $3,085 \mathrm{~g} / \mathrm{cm}^{3}( \pm$ $0.12 \%$ ) e $1,37 \mathrm{~m}^{2} / \mathrm{g}$. A curva de distribuição granulométrica, o módulo de finura e os parâmetros $\mathrm{D}_{90}, \mathrm{D}_{50}$ e $\mathrm{D}_{10}$ podem ser verificados na Figura 3.2. A composição química obtida pela análise DRX-Rietveld pode ser encontrada na Tabela 3.2.

Figura 3.2 - Curva granulométrica do cimento

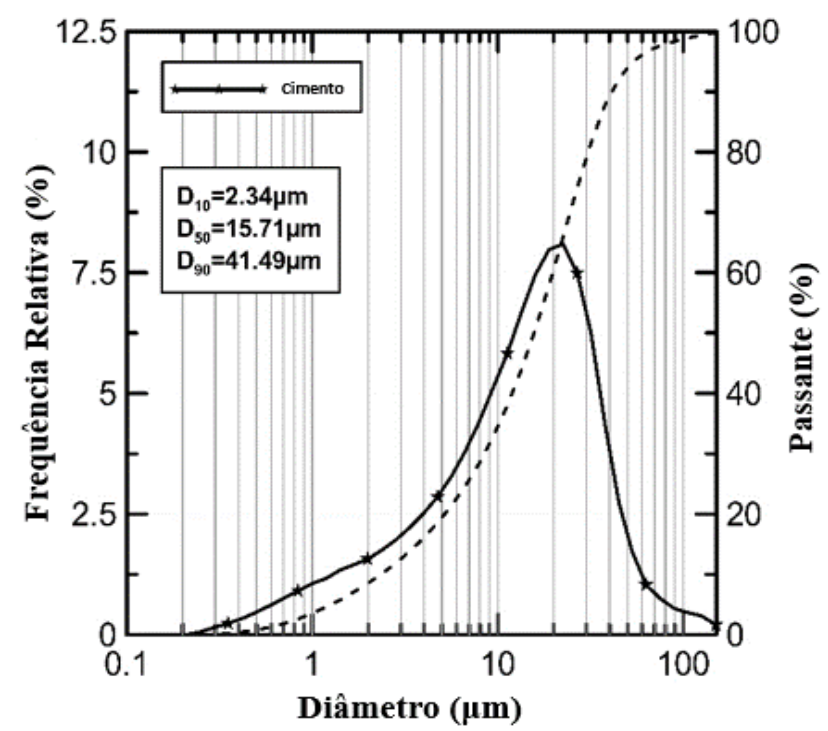

Tabela 3.2 - Composição química do cimento

\begin{tabular}{cc}
\hline Mineral & Porcentagem \\
\hline Alita $\left(\mathrm{C}_{3} \mathrm{~S}\right)$ & $55,4 \%$ \\
Belita $\left(\mathrm{C}_{2} \mathrm{~S}\right)$ & $13,8 \%$ \\
Ferrita & $9,3 \%$ \\
Hemidratos & $6,9 \%$ \\
Calcita & $3,5 \%$ \\
$\mathrm{C}_{3}$ A Ortorrômbico & $3,3 \%$ \\
C $_{3}$ A Cúbico & $2,1 \%$ \\
Periclásio & $1,7 \%$ \\
Gipsita & $1,1 \%$ \\
Outros & $2,9 \%$ \\
\hline
\end{tabular}

Fonte: Elaborado pelo autor

\subsubsection{Sílica ativa}

A sílica ativa Elkem $920-\mathrm{U}\left(98 \% \quad \mathrm{SiO}_{2}\right)$ foi utilizada como material cimentício suplementar. A adição apresentou massa específica de $2,37 \mathrm{~g} / \mathrm{cm}^{3}( \pm 0.76 \%)$ e área específica de $16 \mathrm{~m}^{2} / \mathrm{g}$. A curva de distribuição granulométrica e os parâmetros $\mathrm{D}_{90}, \mathrm{D}_{50}$ e $\mathrm{D}_{10}$ para sílica ativa podem ser encontrados na Figura 3.3.

\subsubsection{Agregados miúdos}

Os agregados miúdos empregados na mistura foram areia de rio e areia artificial. A distribuição granulométrica, o módulo de finura e os parâmetros $\mathrm{D}_{90}, \mathrm{D}_{50}$ e $\mathrm{D}_{10}$ foram definidos e apresentados na Figura 3.4. A massa específica obtida para a areia de rio foi $2,67 \mathrm{~g} / \mathrm{cm}^{3}( \pm$ $0,05 \%)$ e para a areia artificial foi $2,70 \mathrm{~g} / \mathrm{cm}^{3}( \pm 0,05 \%)$. 
Figura 3.3 - Curva granulométrica da sílica ativa

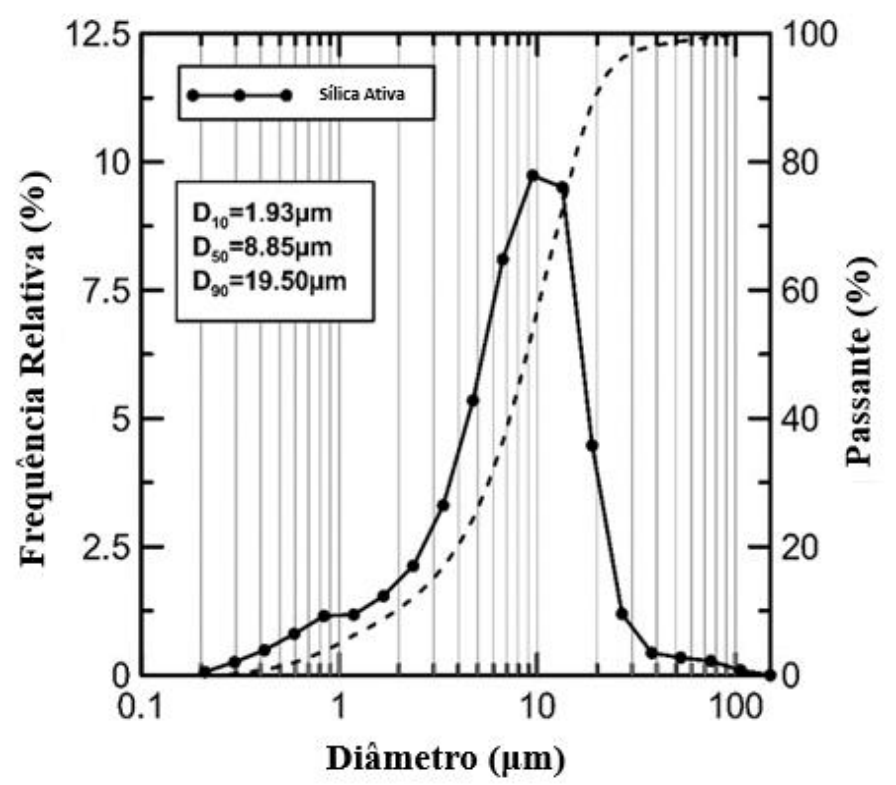

Fonte: Elaborado pelo autor

Figura 3.4 - Curvas granulométricas dos agregados miúdos
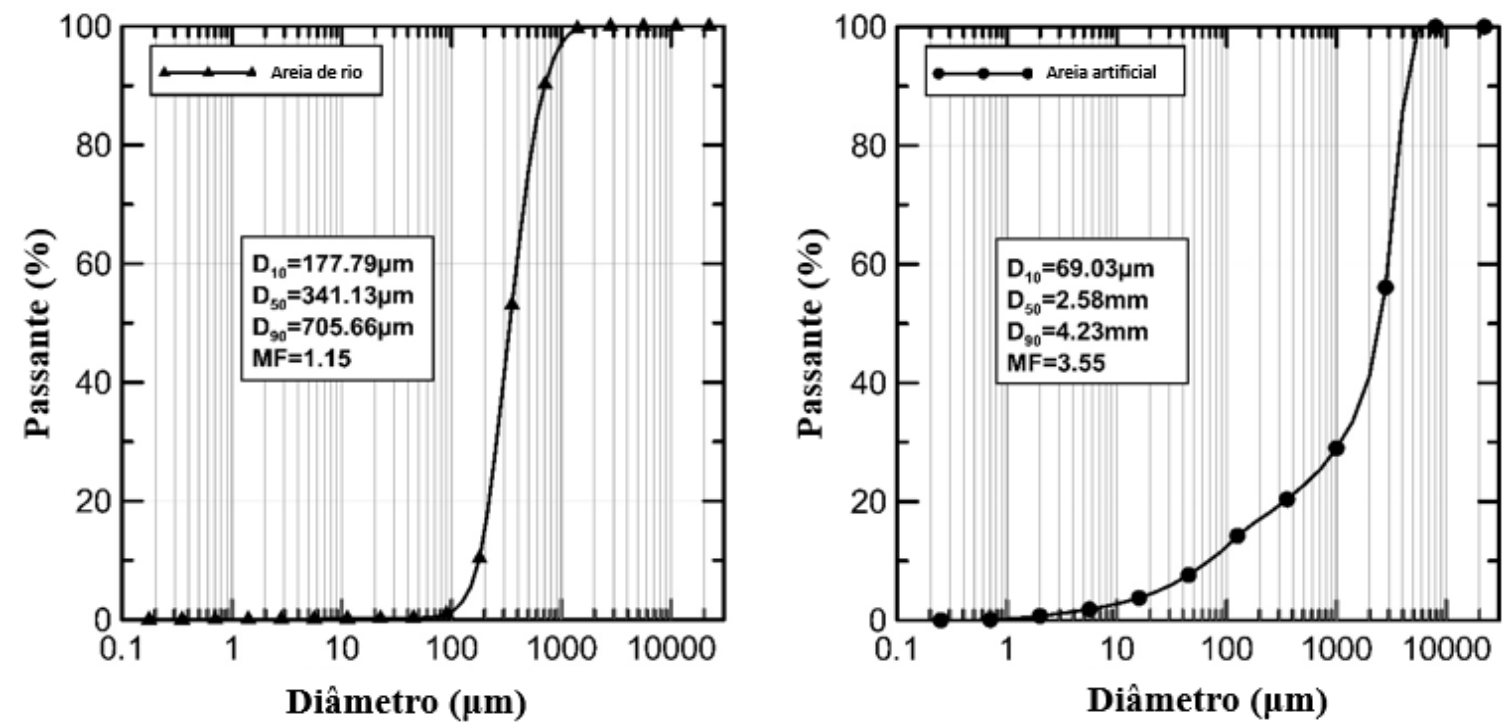

Fonte: Elaborado pelo autor

\subsubsection{Agregados graúdos}

Os agregados graúdos empregados na mistura foram as pedras britadas de origem granítica, com dimensões máximas de 9,5 mm (brita 0) e $19 \mathrm{~mm}$ (brita 1). As características físicas destes agregados foram determinadas a partir das normas NBR NM 45 (2006), NBR NM 53 (2003), NBR NM 248 (2003). A curva de distribuição granulométrica, o módulo de finura e os parâmetros $\mathrm{D}_{90}, \mathrm{D}_{50}$ e $\mathrm{D}_{10}$ foram definidos e apresentados na Figura 3.5. A massa específica do 
agregado graúdo brita 0 foi $2,67 \mathrm{~g} / \mathrm{cm}^{3}( \pm 0,26 \%)$ e para o agregado graúdo brita 1 foi 2,65 $\mathrm{g} / \mathrm{cm}^{3}( \pm 0,07 \%)$. A absorção encontrada foi de $0,5 \%( \pm 0,1)$.

Figura 3.5 - Curvas granulométricas dos agregados graúdos
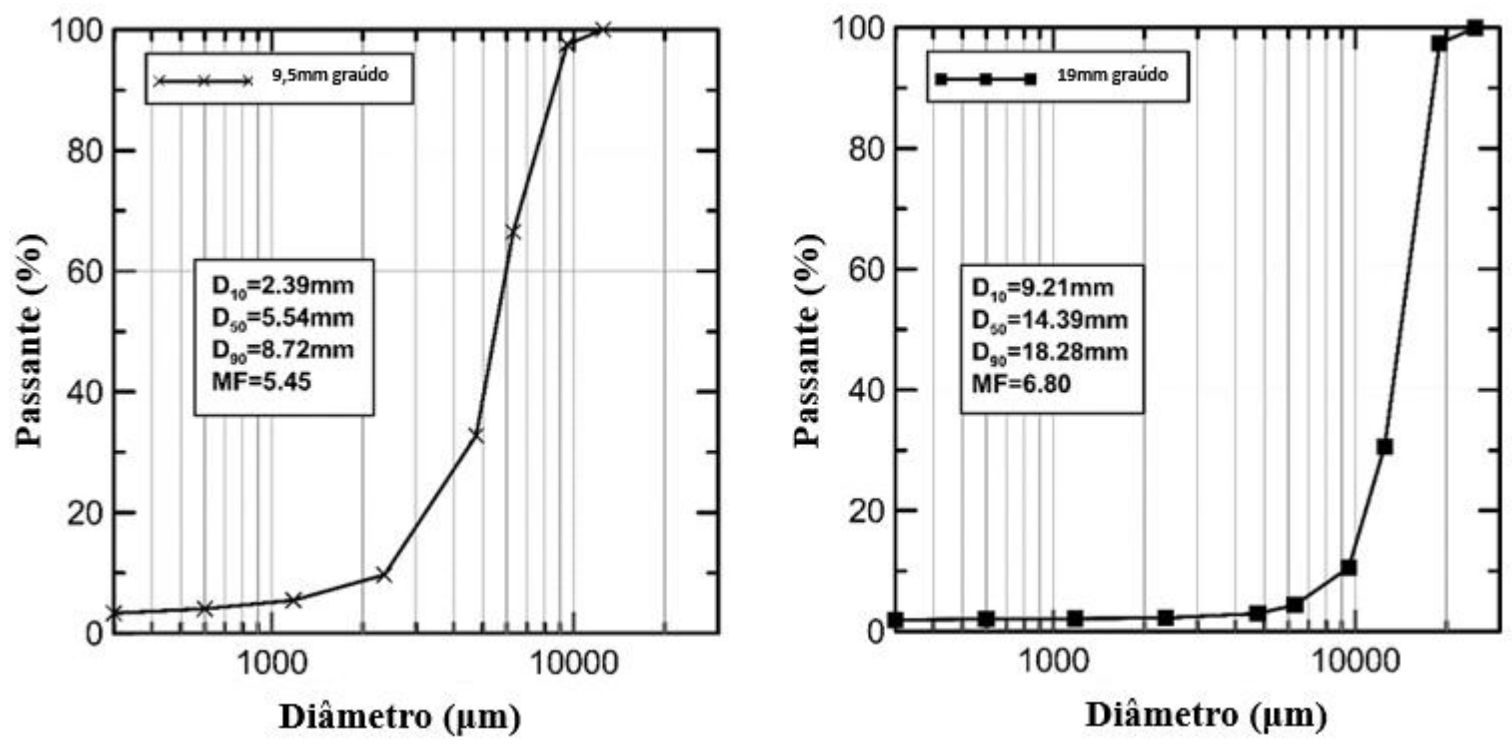

Fonte: Elaborado pelo autor

\subsubsection{Superplastificante}

Foi utilizado um superplastificante de última geração, Grace ADVA Cast 525, baseado em policarboxilato. Este superplastificante foi desenvolvido para fornecer trabalhabilidade à mistura sem causar segregação e é utilizado com frequência em concreto pré-moldado que exige alta resistência e alta durabilidade. A Tabela 3.3 apresenta a especificação do produto fornecida pelo fabricante. O superplastificante atende aos requisitos da norma NBR 11768 (ABNT, 2011).

Tabela 3.3 - Especificações do aditivo superplastificante

\begin{tabular}{cc}
\hline \multicolumn{2}{c}{ Grace ADVA CAST 525 } \\
\hline Aspecto & Líquido \\
Cor & Amarelo claro \\
Teor de Cloreto & - \\
Massa específica & $1,06 \mathrm{~g} / \mathrm{cm}^{3}$ \\
Teor de álcalis & $0,60 \%$ \\
Ar incorporado & $1,00 \%$ \\
$\mathrm{pH}$ & $5-7$ \\
\hline
\end{tabular}

Fonte: Manual do fabricante 


\subsubsection{Fibras}

A fibra de aço Dramix 3D 80/60BG utilizada nesse estudo foi caracterizada pelo fabricante segundo critérios propostos pela norma NBR 15530 (ABNT, 2019). De acordo com essa norma, a fibra de aço utilizada é classificada como do tipo A (apresenta ancoragem nas extremidades) em função da conformação geométrica, classe I (oriunda de arame trefilado a frio) em função do aço que deu origem à fibra, com seção circular e fator de forma igual a 80. A Figura 3.6 ilustra a fibra de aço utilizada nesse estudo e comumente empregada para aplicações estruturais. As microfibras sintéticas de polipropileno Neomatex FireX foram utilizadas neste estudo na dosagem de $0,8 \mathrm{~kg} / \mathrm{m}^{3}$ para evitar a fragmentação explosiva (spalling) do concreto em altas temperaturas, de modo que cria poros capilares no concreto, reduzindo a pressão interna do vapor de água. Os dados fornecidos pelo fabricante para as fibras de aço e para as microfibras de polipropileno são apresentados na Tabela 3.4.

Tabela 3.4 - Propriedades das fibras de aço e microfibras de polipropileno

\begin{tabular}{ccc}
\hline Características & Fibras de aço & Microfibras de PP \\
\hline Material & Aço & Polipropileno \\
Classificação (NBR 15530) & Tipo A I & - \\
Comprimento & $60 \mathrm{~mm}$ & $12 \mathrm{~mm}$ \\
Massa específica & $7,85 \mathrm{~g} / \mathrm{cm}^{3}$ & $0,91 \mathrm{~g} / \mathrm{cm}^{3}$ \\
Diâmetro equivalente & $0,75 \mathrm{~mm}$ & $30 \mu \mathrm{m}$ \\
Fator de forma (l/d) & 80 & 400 \\
Módulo de elasticidade & $210 \mathrm{GPa}$ & - \\
Resistência à tração & $1225 \mathrm{MPa}$ & - \\
Alongamento máximo & $<4 \%$ & - \\
Área específica superficial & $3,45 \mathrm{~m}^{2} / \mathrm{kg}$ & $147 \mathrm{~m}^{2} / \mathrm{kg}$ \\
Temperatura de fusão & $\sim 1370{ }^{\circ} \mathrm{C}$ & $165^{\circ} \mathrm{C}$ \\
\hline
\end{tabular}

Fonte: Manual do fabricante

Figura 3.6 - Ilustração da fibra de aço do tipo A, classe I, utilizada neste estudo

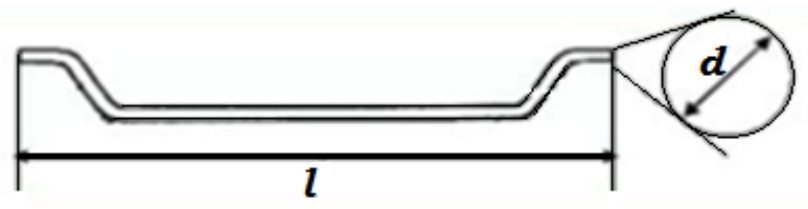

Fonte: NBR 15530 (ABNT, 2019) 


\subsection{Procedimentos adotados para a caracterização da microestrutura da matriz}

Nesta fase, foi realizada uma investigação do grau de dano gerado pela temperatura elevada na microestrutura da matriz cimentícia, por meio de técnica de caracterização microestrutural adequada, identificando os processos de degradação ocorridos. Os produtos de hidratação da pasta de cimento foram avaliados em função das temperaturas-alvo adotadas. Foi possível justificar o comportamento macroestrutural do CRF exposto a elevadas temperaturas a partir da investigação microestrutural, por meio de análises qualitativas e quantitativas em amostras submetidas a temperaturas específicas. Essa verificação complementa a análise do comportamento do material, especialmente quando sincronizada com a degradação da fibra, o que afeta a interação fibra-matriz e, portanto, o comportamento pós-fissuração.

\subsubsection{Produção, moldagem e cura}

Amostras removidas de corpos de prova de concreto fornecem dados inconsistentes sobre os produtos de hidratação da pasta de cimento, devido à grande quantidade de quartzo presente (cerca de 85\%) e baixo volume de pasta, o que fornece informações falsas para a análise Rietveld, já que a precisão dessa metodologia é significativamente reduzida se a quantidade de cada hidrato representar apenas uma pequena porção da amostra (SCRIVENER et al., 2017). Dessa forma, foi produzida uma pasta de cimento com CP-V ARI RS (equivalente ao CEM I 52.5R), sílicia ativa em um teor de 5,5\% da massa de cimento e uma relação água/materiais cimentícios igual a 0,39. O seguinte procedimento foi adotado: $200 \mathrm{~g}$ de cimento, $11 \mathrm{~g}$ de sílica ativa, $82 \mathrm{~g}$ de água e $1,44 \mathrm{~g}$ de superplastificante, que foram misturados durante 120 segundos a $10000 \mathrm{rpm}$ em um misturador Makita RT0700C. Nove pequenos moldes circulares de poliestireno com $4 \mathrm{~cm}$ de diâmetro foram preenchidos com a pasta de cimento, de forma que cada um recebeu $20 \mathrm{~g}$ de pasta. As amostras foram então seladas com filme plástico e curadas em câmara úmida por 72 h. Após o período de cura, as amostras foram armazenadas em temperatura ambiente $\left(25^{\circ} \mathrm{C}\right)$ até a idade de 150 dias.

\subsubsection{Aquecimento das amostras}

Com a idade de 150 dias, as amostras de pasta de cimento foram submetidas às temperaturas específicas de $150,300,450,600$ e $750{ }^{\circ} \mathrm{C}$ durante um período de $2 \mathrm{~h}$. Para este fim, um forno elétrico EDG FC modelo EDG10P-S (Figura 3.7) foi utilizado, cuja taxa de aquecimento empregada foi de $(20 \pm 3)^{\circ} \mathrm{C} / \mathrm{min}$. 
O resfriamento foi realizado com o forno fechado durante o período de $24 \mathrm{~h}$ para todas as amostras. Após a conclusão do procedimento de resfriamento, todas as amostras foram armazenadas em sacos plásticos selados e mantidas dentro de um dessecador com presença de vácuo, a fim de reduzir a possibilidade de reidratação da pasta de cimento.

Figura 3.7 - Forno elétrico utilizado para aquecimento das amostras de pasta de cimento

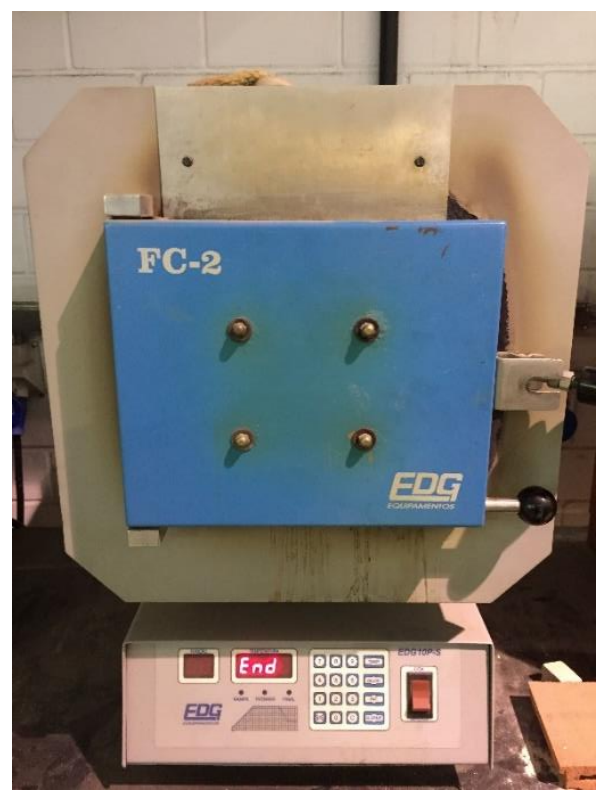

Fonte: Acervo do autor

\subsubsection{Caracterização mineralógica por Difração de raios X (DRX)}

Alterações químicas da matriz, fases presentes na amostra e os produtos de hidratação foram avaliados em função da temperatura. As amostras de pasta de cimento à temperatura ambiente e após exposição a elevadas temperaturas foram trituradas e desaglomeradas em peneira malha 270 (abertura $53 \mu \mathrm{m}$ ) e caracterizadas (Figura 3.8).

Figura 3.8 - Amostra de pasta de cimento e material utilizado para pulverizá-la

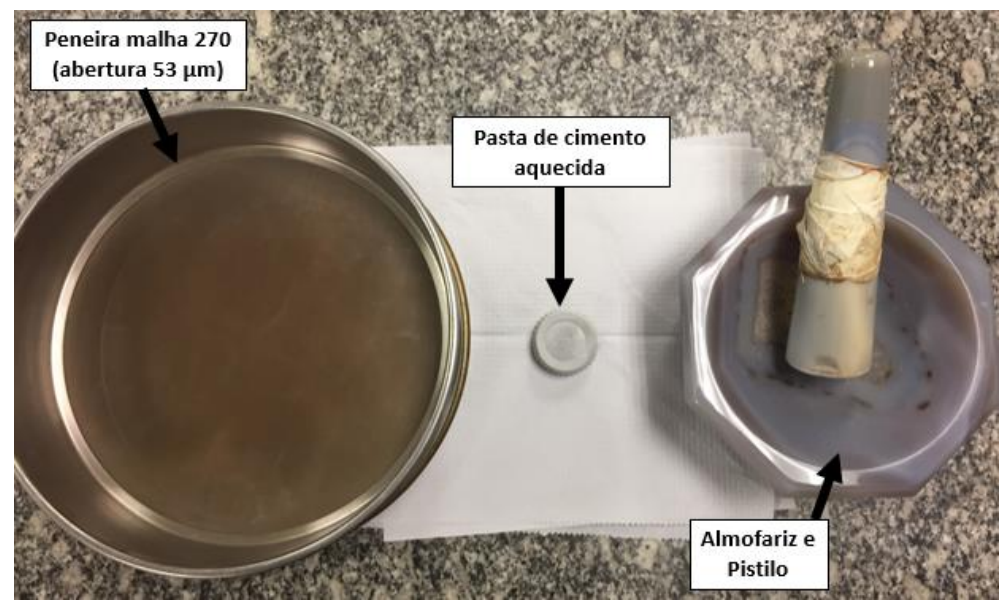

Fonte: Acervo do autor 
A difração de raios $\mathrm{X}(\mathrm{DRX})$ foi realizada em um difratômetro de pó da marca PANalytical e modelo X'Pert PRO PW 304000 em geometria de reflexão Bragg-Brentano, utilizando-se fonte de radiação monocromática $\mathrm{Cu}-\mathrm{K} \alpha$ filtrada com $\mathrm{Ni}(\lambda=1,5418 \AA)$ e um detector X'celerator (comprimento ativo de $2,214^{\circ}$ ), operando com tensão de $45 \mathrm{kV}$ e corrente de 40 mA. Os porta-amostras são cilíndricos, com diâmetro interno de $27 \mathrm{~mm}$ e profundidade de 8 $\mathrm{mm}$, contendo aproximadamente $2 \mathrm{~g}$ de pasta. Durante este ensaio, os porta-amostras foram girados em torno do eixo do goniômetro vertical a uma taxa de 0,5 rotação por segundo. A leitura de $2 \theta$ foi realizada de $4^{\circ}$ a $80^{\circ}$, com um passo de $0,02^{\circ}(2 \theta)$ e 200 s por passo. Dados quantitativos sobre silicatos e aluminatos para cada temperatura-alvo foram determinados por refinamento dos parâmetros da estrutura cristalina pelo método de Rietveld, utilizando o software X'Pert High Score Plus, tomando como base a estratégia de análise proposta por Salvador et al. (2016). O conteúdo amorfo foi determinado com a utilização do pó de Alumina $\left(\alpha-\mathrm{Al}_{2} \mathrm{O}_{3}\right)$, material padrão de referência produzido pelo Instituto Nacional de Padrões e Tecnologia (NIST), com o código SRM 676a.

\subsection{Composição e preparação das amostras de CRFA}

Foram produzidos prismas (100x100x350 mm) e cilindros (com diâmetro de $100 \mathrm{~mm}$ e altura de $200 \mathrm{~mm}$ ) de concreto de alta resistência reforçado com fibras de aço (CRFA), cuja composição, indicada na Tabela 3.5 (para o teor médio de fibra de aço empregado deste estudo) foi baseada na dosagem de segmentos pré-moldados utilizados no revestimento de túneis da Linha 6 do Metrô de São Paulo. Amostras de CRFA com teores de fibra de aço de $20 \mathrm{~kg} / \mathrm{m}^{3}$ $\left(0,26 \%\right.$ em volume ) e $70 \mathrm{~kg} / \mathrm{m}^{3}(0,90 \%$ em volume) também foram produzidas. A relação água/materiais cimentícios $(\mathrm{a} / \mathrm{c})$ foi mantida constante em 0,39 .

Tabela 3.5 - Dosagem de materiais para produção de $1 \mathrm{~m}^{3}$ de CRFA (Teor de fibras de aço = $35 \mathrm{~kg} / \mathrm{m}^{3} \mathrm{ou} 0,45 \%$ em volume)

\begin{tabular}{lc}
\hline Materiais & Dosagem $\left(\mathbf{k g} / \mathbf{m}^{\mathbf{3}}\right)$ \\
\hline Cimento Portland & 400 \\
Sílica ativa & 22 \\
Areia de rio & 403 \\
Areia artificial & 269 \\
Agregado graúdo $\mathrm{d}_{\text {máx }}: 9,5 \mathrm{~mm}$ & 330 \\
Agregado graúdo d dáx: $19 \mathrm{~mm}$ & 770 \\
Água & 165 \\
Superplastificante & 3 \\
Microfibras de polipropileno & 0,8 \\
Macrofibras de aço & 35 \\
\hline
\end{tabular}


As produções de concreto ocorreram no Hall Tecnológico da Escola Politécnica da USP em temperatura ambiente $\left(25^{\circ} \mathrm{C}\right)$, em um misturador de eixo inclinado (betoneira) com capacidade de 300 litros e com rotação de tambor de 34 rpm, obedecendo a seguinte ordem:

a) Molhagem da betoneira, para evitar que os materiais sejam absorvidos pelas paredes internas da mesma;

b) Adição de cimento, sílica ativa, agregados graúdos e um terço da água total ao misturador. Mistura por 3 minutos;

c) Adição de areia de rio, areia artificial e um terço de água total ao misturador. Mistura por 3 minutos;

d) Diluição do aditivo superplastificante na água restante e adição da solução obtida ao misturador. Mistura por 3 minutos;

e) Adição das macrofibras de aço e das microfibras de polipropileno de forma fracionada, com a betoneira em movimento. Mistura por 6 minutos.

Para determinação da sua consistência, o CRFA produzido foi submetido, no estado fresco, ao abatimento de tronco de cone (ABNT, 1998), conforme apresentado na Figura 3.9, e apresentou slump de $(4 \pm 1) \mathrm{cm}$ (média obtida por três determinações) nas três composições.

Figura 3.9 - Ensaio de abatimento do tronco de cone (slump test) do CRFA
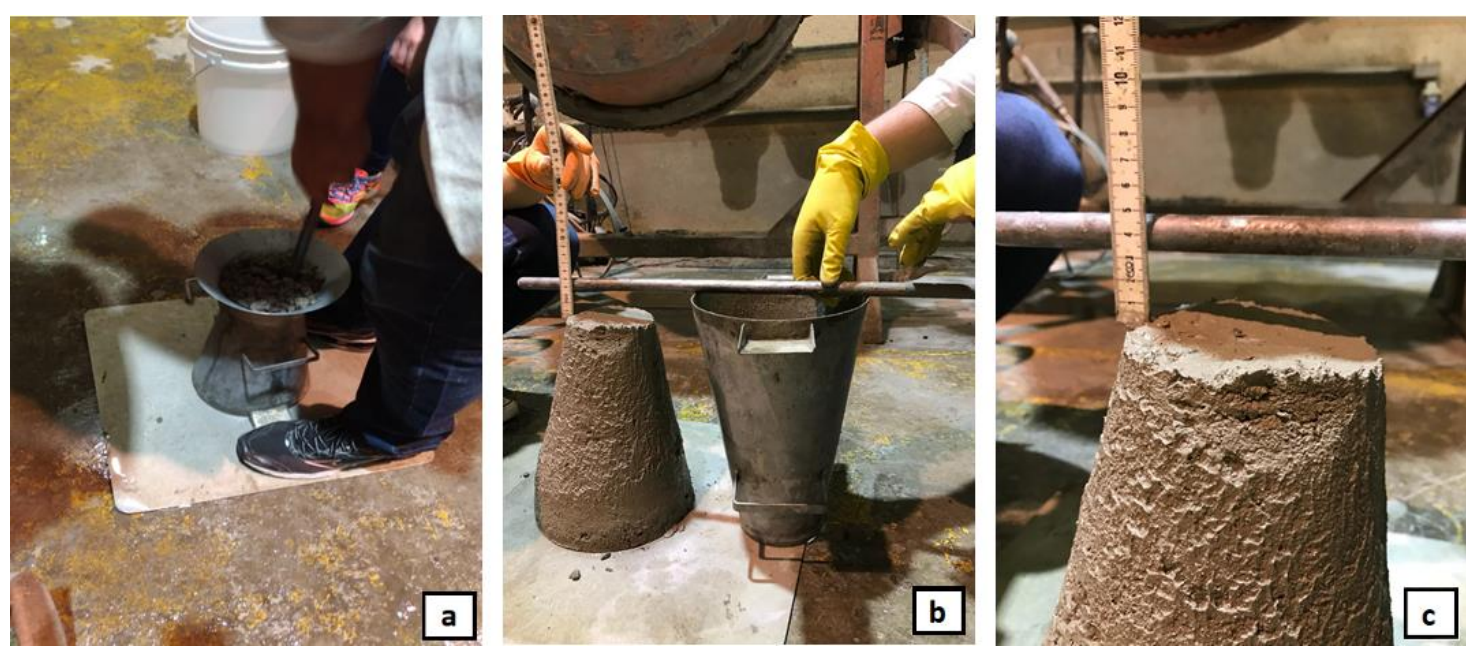

Fonte: Acervo do autor

A moldagem dos corpos de prova prismáticos - com dimensões nominais (largura e altura) de $100 \mathrm{~mm}$ e comprimento de $350 \mathrm{~mm}$ - foi realizada seguindo as recomendações da EN 14651 (2007), em conformidade com a EN 12350-1 (2009) e a EN 12390-2 (2009), como ilustrado na Figura 3.10a. Os moldes, ilustrados na Figura 3.10b, receberam uma fina camada de óleo 
mineral para auxiliar a desforma e foram preenchidos até aproximadamente $90 \%$ de seu volume. Em seguida, completou-se o volume com concreto fresco e o molde foi nivelado enquanto se realizava o adensamento.

Figura 3.10 - (a) Procedimento para enchimento do molde prismático; (b) Moldes prismáticos utilizados
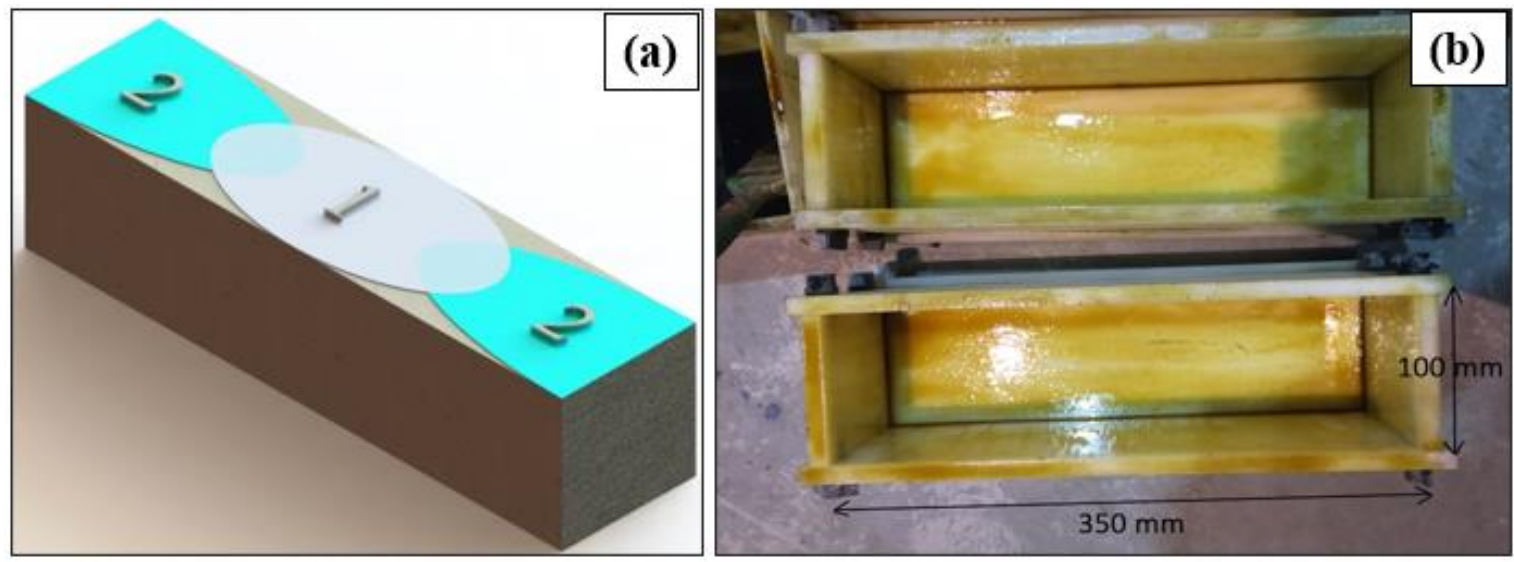

Fonte: Acervo do autor

O adensamento dos corpos de prova prismáticos e cilíndricos foi realizado exclusivamente por vibração externa, com a utilização de mesa vibratória. O tempo de vibração foi de aproximadamente $30 \mathrm{~s}$ em uma frequência de $60 \mathrm{~Hz}$, o que garantiu um aspecto liso à superfície do concreto, sem existir afloramento de bolhas de ar e sem causar segregação. Após moldados e adensados, os corpos de prova foram cobertos por uma lona plástica e mantidos à temperatura ambiente, onde foram desmoldados após 24 h. Em seguida, foram curados em câmara úmida por $72 \mathrm{~h}$ e, posteriormente, à temperatura ambiente por 150 dias. Após esse período, o concreto se encontrava estabilizado, de forma que não apresentava mais ganhos significativos de resistência devido ao processo de hidratação.

Levando em consideração as composições com diferentes teores de fibra de aço, foram produzidos, ao todo, 88 corpos de prova prismáticos $(100 \times 100 \times 350 \mathrm{~mm})$ de CRFA, os quais: 60 (20 por teor de fibra de aço) foram cortados e deram origem à 180 amostras cúbicas de 100x100x100 mm (60 por teor de fibra de aço), destinadas ao ensaio DEWS (Figura 3.11) após aquecimento em temperaturas específicas em forno elétrico; 24 corpos de prova prismáticos foram destinados ao ensaio de flexão, onde metade foi ensaiada após exposição ao fogo; e 4 corpos de prova prismáticos foram cortados, dando origem a 12 amostras cúbicas destinadas ao ensaio DEWS após exposição ao fogo. Pequenos defeitos superficiais foram eliminados por meio do processo de retificação dos cubos, o que garantiu o paralelismo entre as faces opostas. Além disso, 72 cilindros ( $\varnothing 100 \mathrm{~mm}$ x $200 \mathrm{~mm}$ ) de CRFA (24 por teor de fibra de aço) foram 
destinados aos ensaios de resistência à compressão e determinação do módulo de elasticidade em diferentes temperaturas.

Figura 3.11 - Corte dos corpos de prova prismáticos

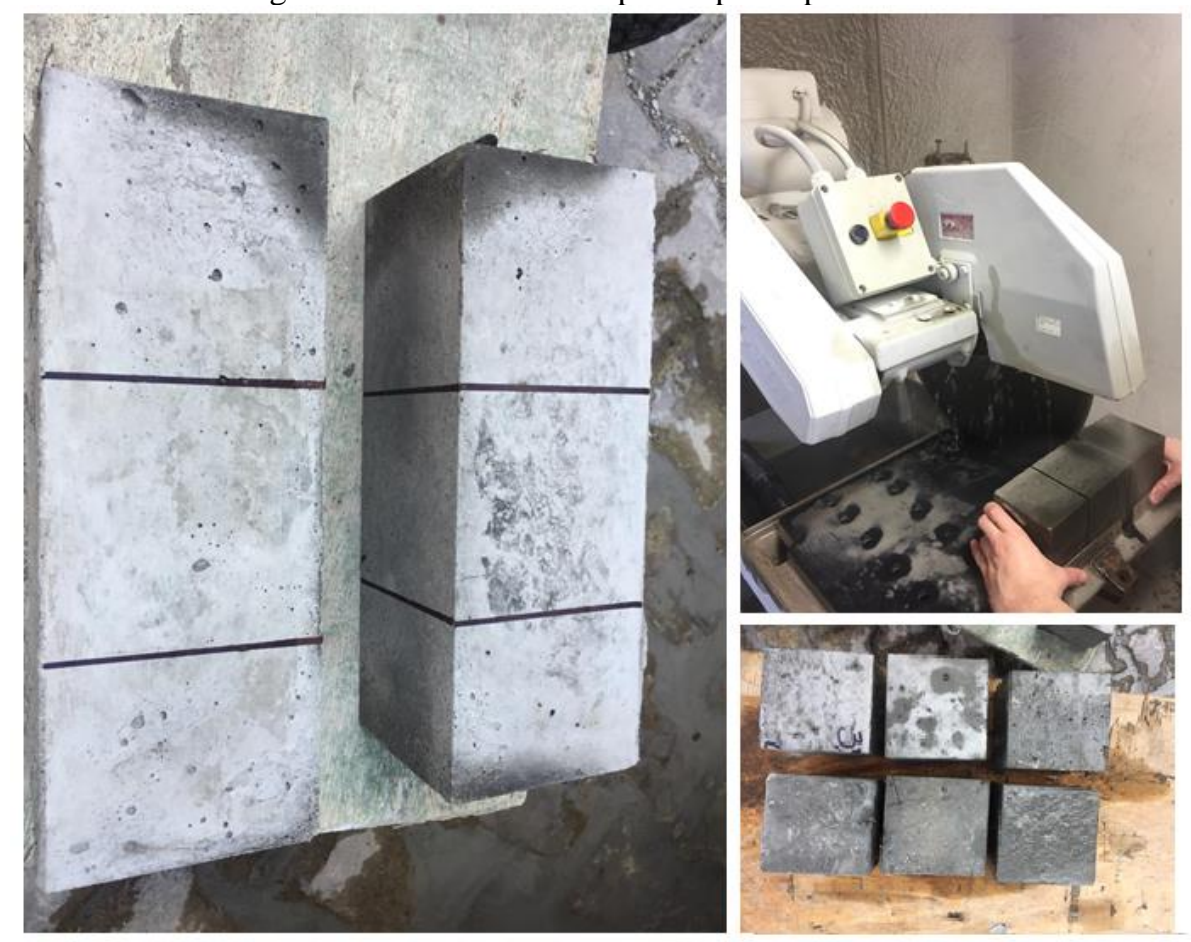

Fonte: Acervo do autor

O procedimento de preparação das amostras cúbicas para o ensaio DEWS seguiu o recomendado no estudo de Borges et al. (2019). Após identificação dos cubos por temperatura, executaram-se cuidadosamente os cortes triangulares das cunhas em $45^{\circ}$ ao longo de dois lados opostos do cubo, visto que é de fundamental importância manter esta angulação, já que os roletes responsáveis pela transferência de carga da prensa para a amostra foram apoiados sobre elas. Os cortes foram realizados nas faces perpendiculares à superfície de rasamento, respeitando a orientação de moldagem, como apresentado no desenho esquemático da Figura 3.12. Dessa forma, a direção principal do ensaio era idêntica para todos os ensaios e paralela ao eixo principal do prisma. Também foi realizada a execução dos entalhes, localizados no vértice das cunhas (Figura 3.12b), com $5 \mathrm{~mm}$ de profundidade e $2 \mathrm{~mm}$ de espessura, cuja função é induzir o posicionamento da fissura na matriz de concreto no plano vertical compreendido entre os entalhes, região identificada como superfície de fratura ou ligamento. As dimensões das amostras são apresentadas na Figura 3.13. 
Figura 3.12 - Preparação das amostras cúbicas para o ensaio DEWS

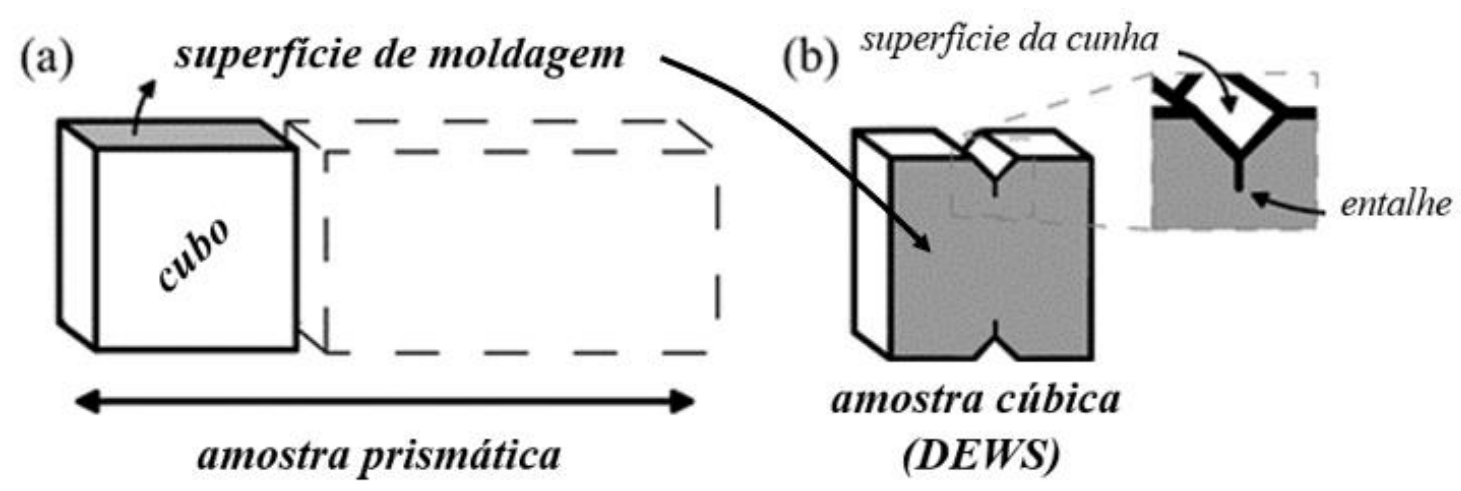

Fonte: Elaborado pelo autor

Figura 3.13 - Configuração do corpo de prova para o ensaio DEWS

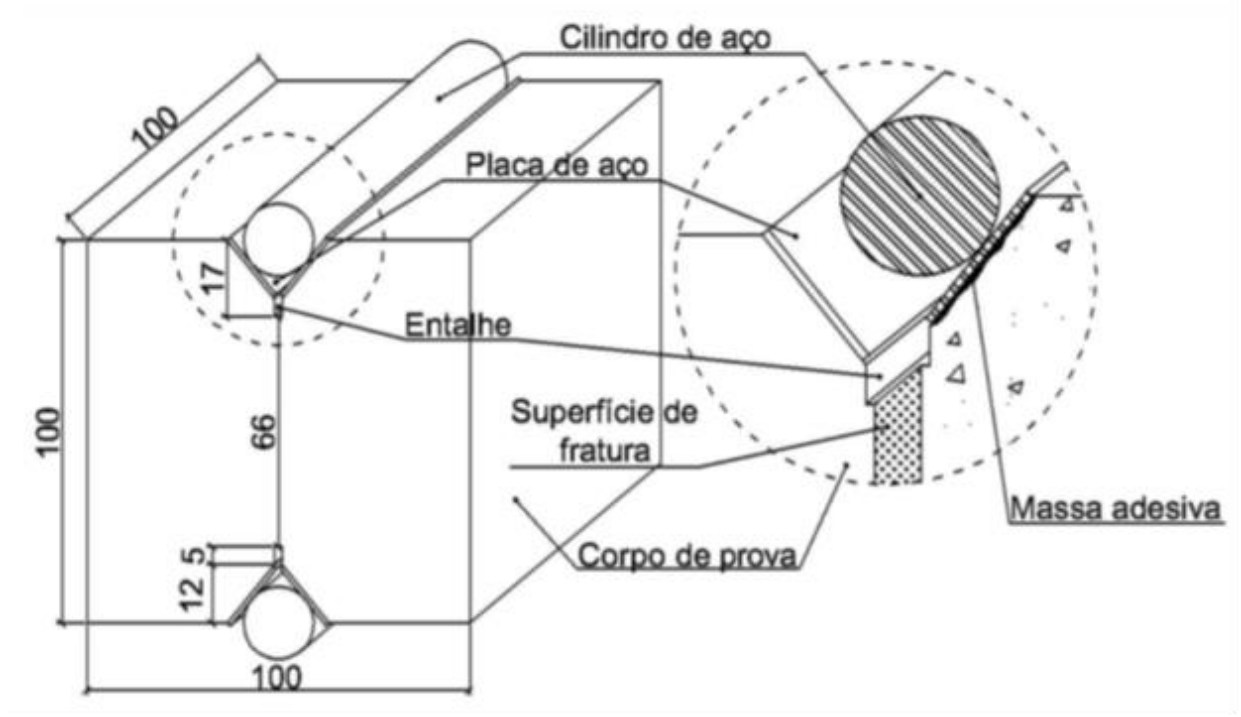

Fonte: Elaborado pelo autor

A extração das amostras cúbicas a partir das prismáticas e a execução dos entalhes e cunhas foram realizadas antes do procedimento de aquecimento para amostras aquecidas em forno e após o procedimento de aquecimento para amostras expostas ao fogo. Essa diferença de metodologia foi adotada para mitigar a influência do aquecimento lateral durante a simulação de incêndio (SERAFINI et al., 2019a). Para as amostras expostas ao fogo, as cunhas triangulares foram cortadas ao longo de dois lados opostos dos cubos na face posicionada a $90^{\circ}$ da face exposta ao fogo, respeitando a mesma orientação das amostras aquecidas em forno, o que visa mitigar os danos às amostras. 


\subsection{Procedimentos de aquecimento empregados para o CRFA}

\subsubsection{Aquecimento em forno elétrico}

A avaliação do compósito em temperaturas específicas, por meio do aquecimento em fornos elétricos é importante para correlacionar o comportamento do material em função da temperatura. Uma vez determinada essa correlação torna-se possível verificar a contribuição de cada camada do CRFA em um elemento afetado pelo fogo em função do gradiente de temperatura formado. Dessa forma, é possível inferir o comportamento global do elemento. Assim, a avaliação do comportamento do CRFA foi realizada por meio da análise de corpos de prova submetidos a diferentes faixas de temperaturas, o que também foi correlacionado com o grau de dano sofrido pela microestrutura do compósito.

Devido à limitação de espaço interno dos fornos disponíveis, dificultando o aquecimento simultâneo de uma quantidade significativa de amostras, utilizou-se prismas de menores dimensões em relação ao preconizado pela EN 14651 (2007). Isso contribuiu para que a homogeneização da temperatura ocorresse de maneira mais rápida e abrangente nas amostras cúbicas originadas das amostras prismáticas, e serve de modelo para comparação com a uniformização da temperatura ao longo da espessura do elemento estrutural de CRFA.

Assim, os corpos de prova cúbicos $(100 \times 100 \times 100 \mathrm{~mm})$ originados das amostras prismáticas, juntamente com os corpos de prova cilíndricos, foram expostos a temperaturas alvo de $150,300,450,600$ e $750{ }^{\circ} \mathrm{C}$ durante $10,8,6,4$ e 4 horas, respectivamente, em um forno elétrico INFORGEL GENGA, modelo GCR.SP (Figura 3.14), com temperatura máxima de $1000^{\circ} \mathrm{C}$. Procurou-se estabelecer uma taxa de aquecimento agressiva, assim como na curva $\mathrm{H}$, entretanto houve limitação técnica devido à capacidade de aquecimento do forno. Dessa maneira, adotou-se a taxa máxima de aquecimento permitida pelo equipamento utilizado, cujo valor foi de $(12 \pm 1){ }^{\circ} \mathrm{C} / \mathrm{min}$, como ilustrado na Figura 3.15. A duração de exposição foi determinada por meio de simulação numérica embasada no estudo de Carpio et al. (2019), de modo a garantir a estabilidade térmica completa da amostra. Assim, no interior do forno, o aquecimento ocorreu de maneira uniforme em todas as faces dos corpos de prova.

Após o término da exposição ao calor, o forno permaneceu fechado e resfriado até atingir a temperatura ambiente durante um período de $24 \mathrm{~h}$. Esse procedimento de resfriamento lento, com taxa de aproximadamente $0,5^{\circ} \mathrm{C} / \mathrm{min}$, foi adotado com o objetivo de controlar a temperatura de forma a garantir uniformidade de condição de avaliação e evitar o choque térmico, para que não fosse gerado outro tipo de degradação nas amostras. Em seguida, as 
amostras foram seladas em sacos plásticos para evitar o contato com umidade e, consequentemente, reidratação até o momento dos ensaios mecânicos.

Figura 3.14 - (a) Forno elétrico utilizado; (b) amostras no interior do forno após aquecimento

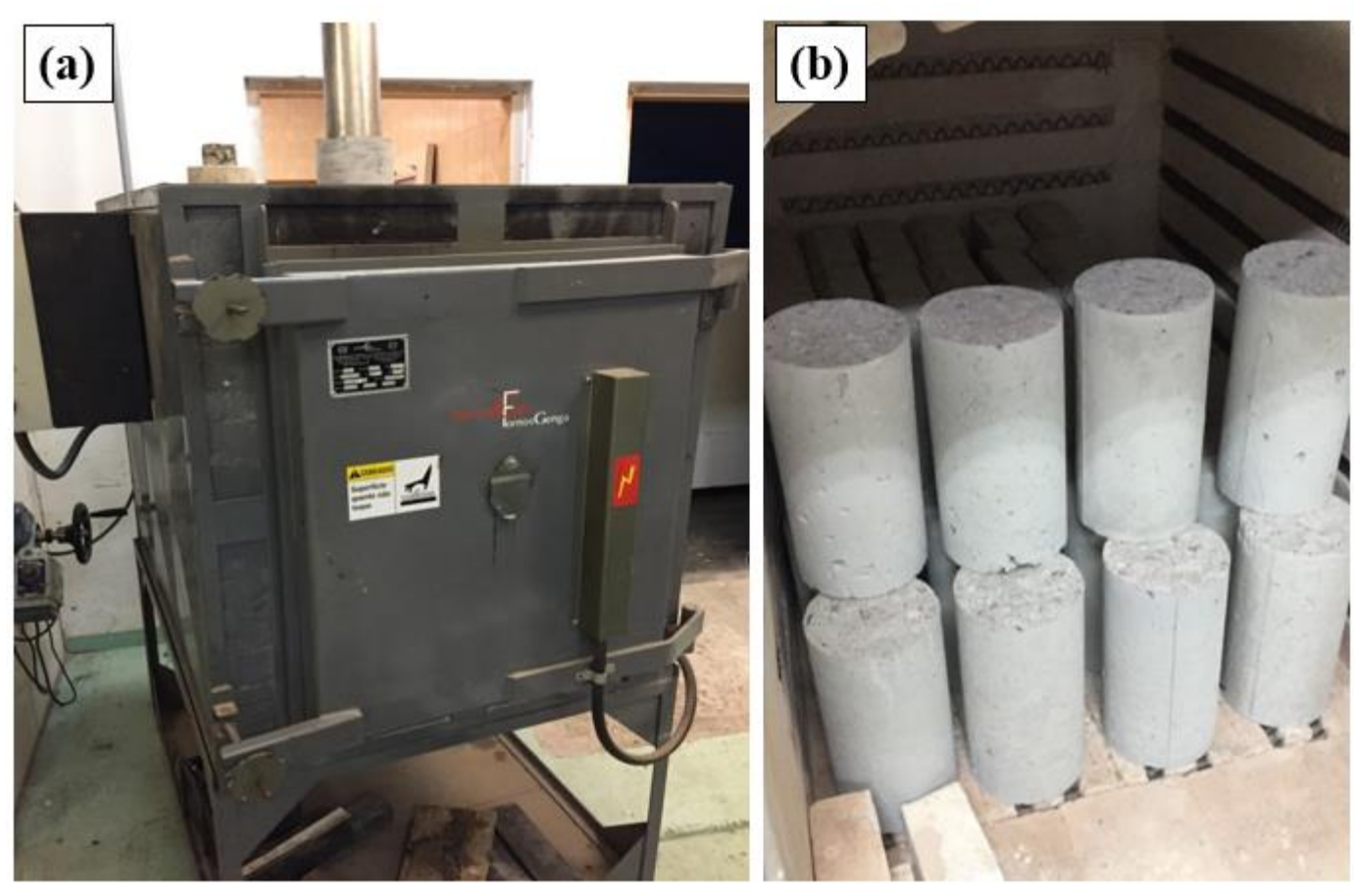

Fonte: Acervo do autor

Figura 3.15 - Gráfico temperatura $\left({ }^{\circ} \mathrm{C}\right) \mathrm{x}$ tempo de ensaio $(\mathrm{min})$ obtido durante aquecimento em mufla elétrica

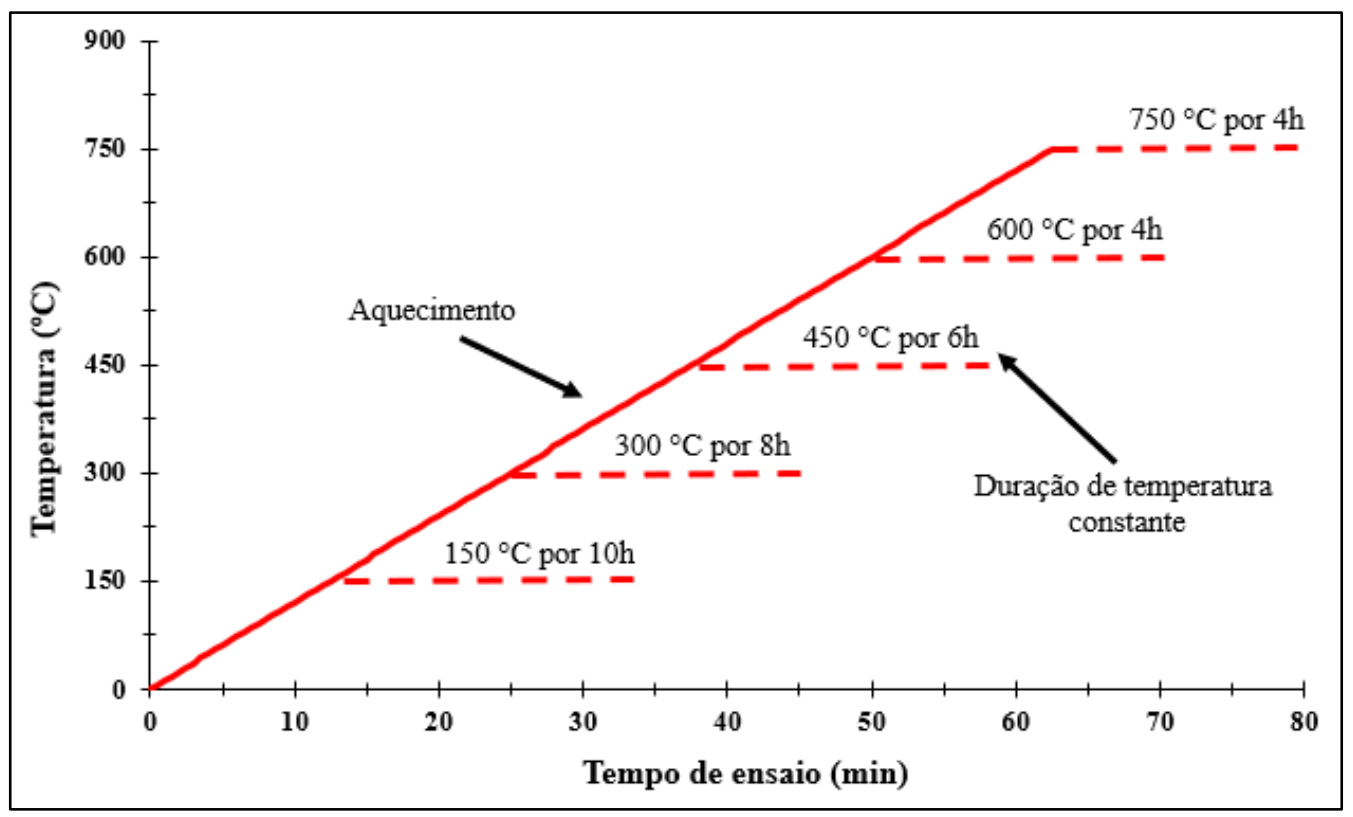

Fonte: Elaborado pelo autor 


\subsubsection{Exposição unifacial ao fogo (simulação por meio da curva "H")}

A partir dos resultados obtidos para a metodologia de aquecimento em fornos, um estudo de mapeamento foi realizado para submeter corpos de prova prismáticos e cúbicos contendo diferentes teores de fibras de aço ao ensaio de fogo direto, com aquecimento unifacial a temperaturas de até $1100{ }^{\circ} \mathrm{C}$ por um período 120 minutos. $\mathrm{O}$ aquecimento durante o ensaio de exposição unifacial ao fogo gera um gradiente térmico que se propaga da face exposta ao fogo em direção à face externa do elemento, o que diferencia dos ensaios realizados em fornos elétricos. $\mathrm{O}$ aquecimento unifacial é o que mais se aproxima da condição de um incêndio real em túneis. Para tal, o regime de aquecimento seguiu as recomendações da norma EN (1991-12:2002), considerando a curva " $\mathrm{H}$ " (para incêndio de hidrocarbonetos) como curva padrão. Esta curva é adotada para o dimensionamento de túneis e demais vias de transporte que comportem veículos movidos a combustíveis inflamáveis (CANER et al., 2005; COSTA, 2008).

Doze amostras cúbicas (4 para cada teor de fibra de aço) e doze prismáticas (4 para cada teor de fibra de aço) foram revestidas por uma manta cerâmica resistente a altas temperaturas, deixando livre apenas uma face que seria exposta ao fogo e a face oposta a esta. Os corpos de prova foram posicionados no quadro de ensaio, constituído por uma parede de blocos cerâmicos, como apresentado na Figura 3.16a. A manta refratária também foi aplicada em toda a superfície restante da parede, deixando expostos apenas os corpos de prova que efetivamente foram ensaiados, como demonstrado na Figura 3.16b. Dessa forma foi possível isolar o calor na alvenaria de blocos cerâmicos, o que poderia levar ao aquecimento lateral dos corpos de prova. Todos esses procedimentos foram realizados para garantir o aquecimento unifacial das amostras de CRFA com o objetivo de simular um incêndio dentro de um túnel. A condição das amostras após o ensaio de exposição ao fogo é apresentada na Figura 3.17b.

A simulação do ambiente do incêndio foi realizada por meio de um simulador de fogo vertical com altura de $2,85 \mathrm{~m}$, largura de $2,85 \mathrm{~m}$ e profundidade de $0,95 \mathrm{~m}$, possuindo revestimento refratário. O forno de ensaio pertence ao Laboratório de Segurança ao Fogo e a Explosões (LSFEx) do Instituto de Pesquisas Tecnológicas (IPT). O sistema de aquecimento (Figura 3.17a) é composto por cinco queimadores industriais a gás metano, dispostos nas duas paredes laterais, distando $0,5 \mathrm{~m}$ da parede que contém as amostras e posicionados de maneira que não haja encontro frontal entre eles. A exaustão dos produtos de combustão é realizada através de conduto com 0,4 $\mathrm{m}$ de altura e 0,7 de largura, localizado na parte superior da parede oposta às amostras ensaiadas. 
Figura 3.16 - (a) Posionamento das amostras no quadro de ensaio para o ensaio de fogo direto; (b) manta refratária aplicada em toda superfície da alvenaria

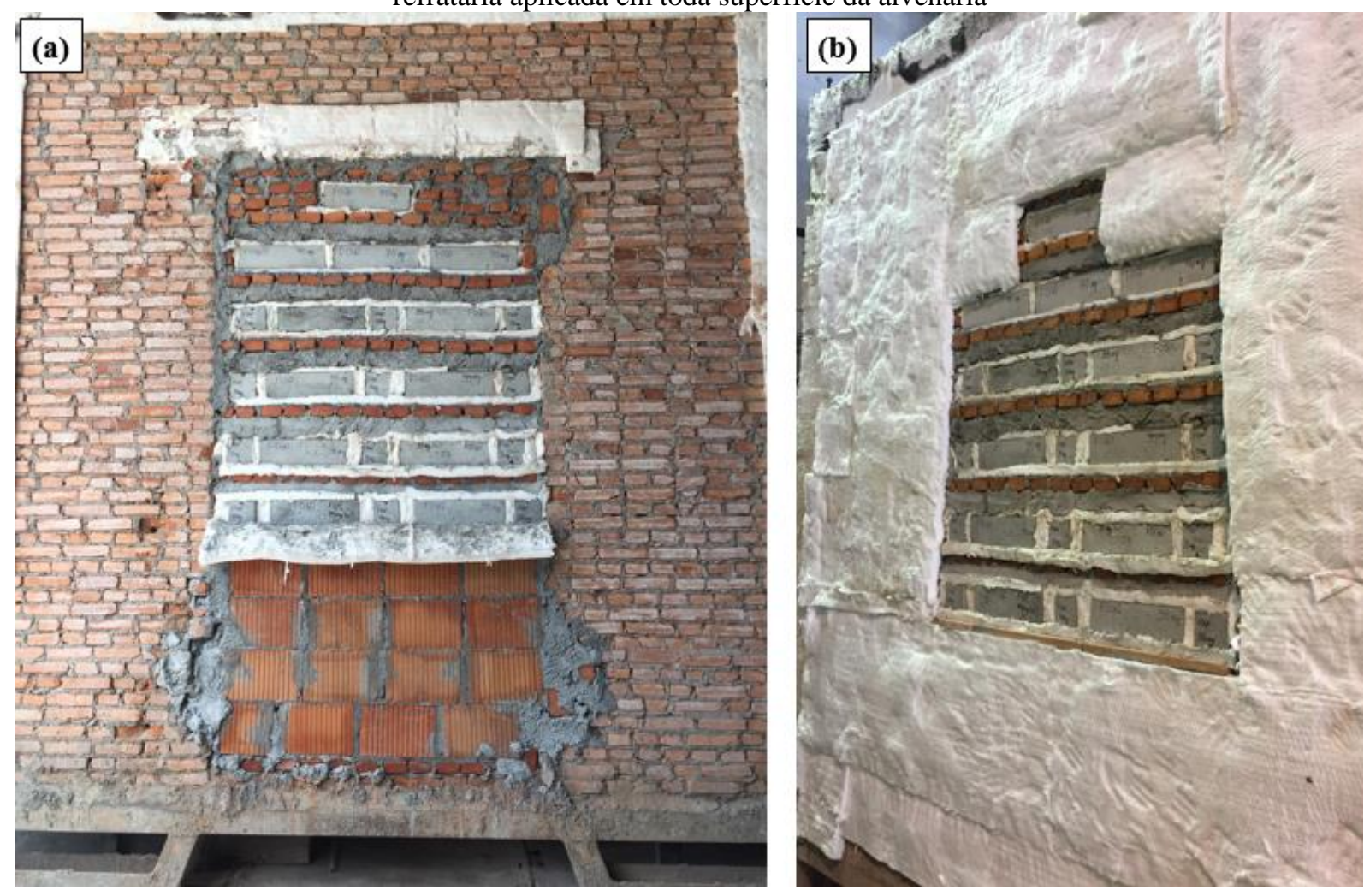

Fonte: Acervo do autor

Figura 3.17 - (a) Sistema de aquecimento e (b) situação das amostras após realização do ensaio de exposição ao
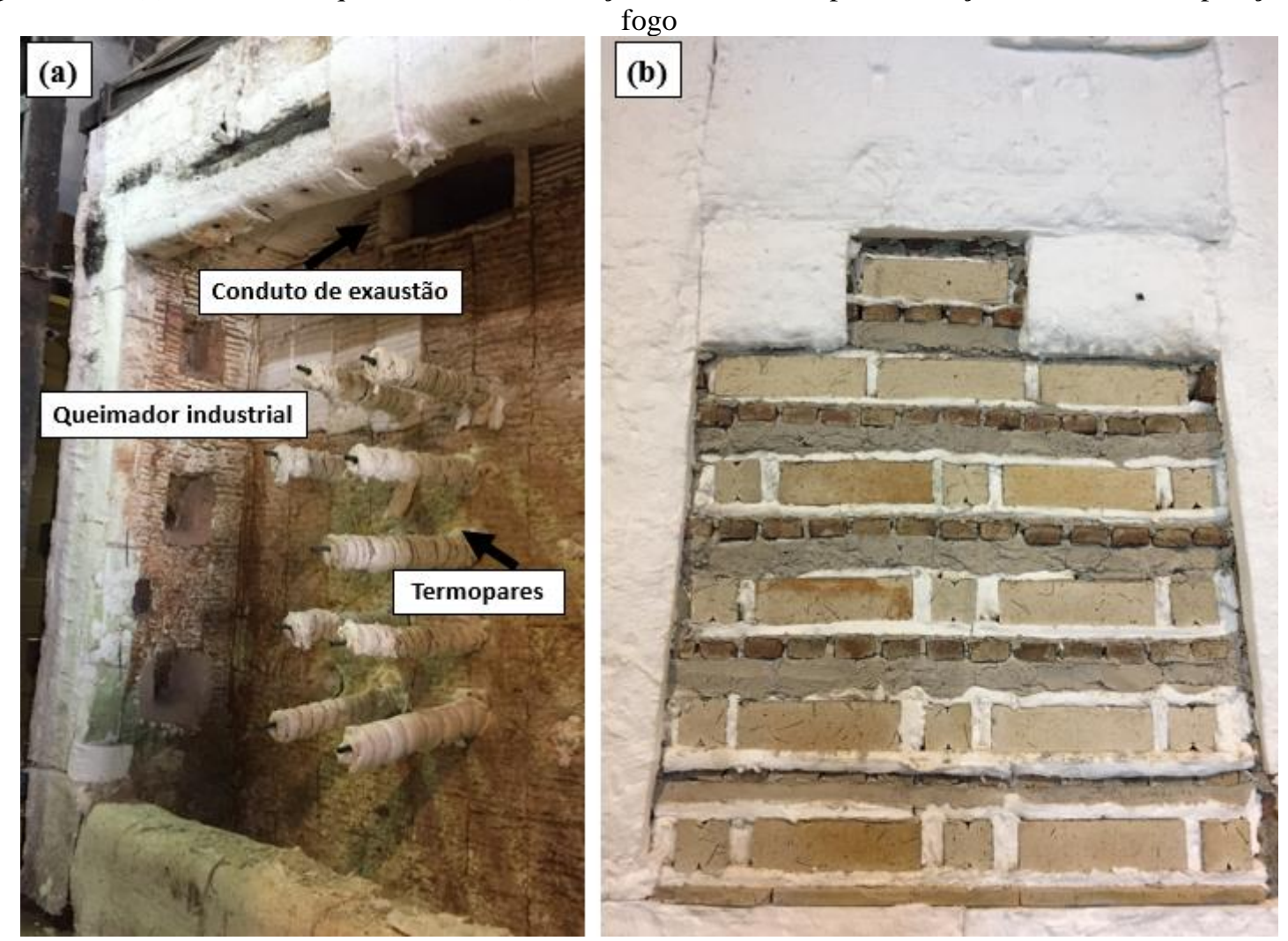

Fonte: Acervo do autor 
A temperatura do forno foi medida por meio de nove termopares mantidos à distância de $150 \mathrm{~mm}$ da face do corpo de prova, distribuídos de maneira simétrica em relação ao arranjo de amostras. Os termopares utilizados para esse fim eram de Cromel-Alumel, com capacidade de medição de até $1320^{\circ} \mathrm{C}$, isolados com miçangas cerâmicas e protegidos com bainha metálica, tendo os fios condutores diâmetro de $1,2 \mathrm{~mm}$. As temperaturas foram registradas e gravadas a cada 30 segundos, de forma que a Figura 3.18 apresenta o gráfico de elevação média de temperatura ao longo do tempo obtido no ensaio de resistência ao fogo em comparação com a curva de incêndio padrão de hidrocarbonetos (Curva "H").

Não foi ouvido nenhum tipo de estouro durante o ensaio, o que poderia caracterizar a ocorrência de lascamentos explosivos nos corpos de prova. Após o término do ensaio, o forno se manteve fechado e resfriando durante um período de $24 \mathrm{~h}$, até que temperaturas próximas à ambiente fossem alcançadas. Passado este período, as amostras prismáticas e cúbicas foram retiradas do quadro de ensaio, passaram por uma inspeção visual a fim de também identificar possíveis lascamentos explosivos e foram armazenadas em sacos plásticos vedados, com o intuito de evitar a reidratação até a data dos ensaios de caracterização mecânica.

Figura 3.18 - Gráfico temperatura $\left({ }^{\circ} \mathrm{C}\right)$ x tempo de ensaio (min) obtido no ensaio de exposição ao fogo

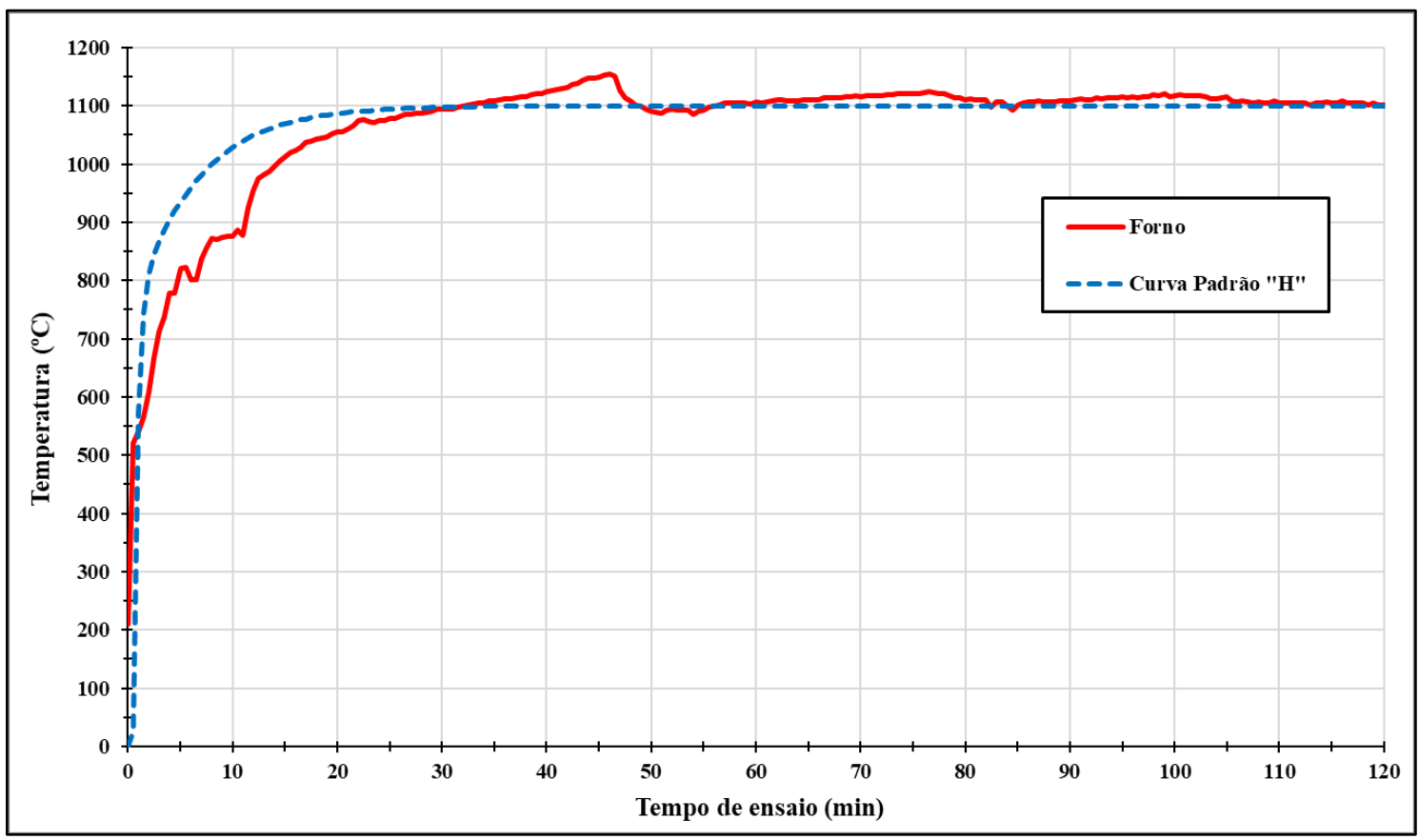

Fonte: Elaborado pelo autor 


\subsection{Avaliação do CRFA por meio de ensaios não destrutivos}

\subsubsection{Método Indutivo}

Por meio da utilização de bobinas geradoras de campo magnético como componente sensor e pela variação da indutância aferida por um medidor LCR, o Método Indutivo - não destrutível, indireto e de fácil execução - proposto por Torrents et al. (2012) e aperfeiçoado por Cavalaro et al. (2014), foi utilizado neste trabalho para determinar o teor e a orientação das fibras utilizando as Leis de Faraday de eletromagnetismo.

Os corpos de prova cúbicos com $100 \mathrm{~mm}$ de aresta, originados dos prismas moldados sem indução de orientação das fibras, foram avaliados por meio do Método Indutivo, antes de serem submetidos ao aquecimento em fornos. Uma bobina circular com duplo enrolamento do tipo Helmholtz, cujas especificações atendem às recomendações propostas por Cavalaro et al. (2014), foi utilizada como elemento sensor do ensaio. Um medidor LCR da Agilent modelo 4263B foi utilizado para aferir a variação da indutância. A Figura 3.19 apresenta a aparelhagem de ensaio utilizada.

Figura 3.19 - Aparelhagem de ensaio utilizada para o Método Indutivo

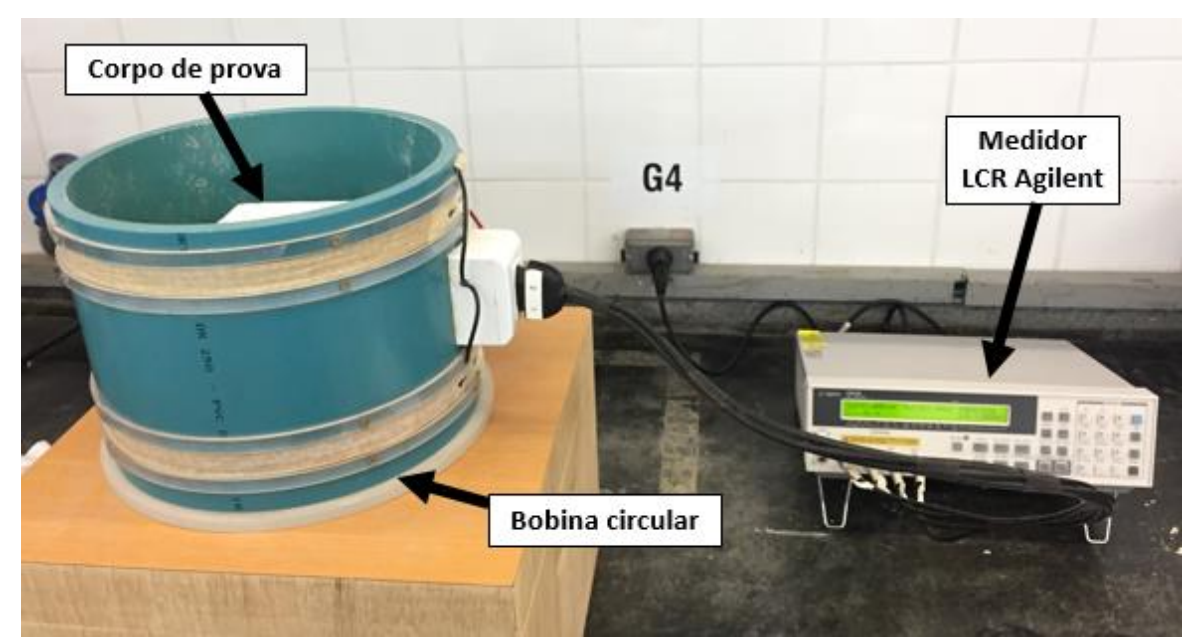

Fonte: Acervo do autor

A quantidade de fibras $\left(\mathrm{C}_{\mathrm{f}}\right)$ é calculada por meio da Equação 3.1, onde: $\mathrm{L}_{\mathrm{i}}$ é a variação da indutância em relação ao eixo i; $\mathrm{B}_{\mathrm{v}, \mathrm{i}}$ é um coeficiente que está relacionado com a geometria da amostra e da bobina; $L_{e}$ é a indutância equivalente em relação ao eixo i e $\beta$ é uma constante previamente definida. Quanto maior o paralelismo das fibras em relação às linhas do campo magnético, maior é a variação da indutância.

$$
C_{f}=\beta \cdot \sum \frac{L_{i}}{B_{v, i}}=\beta \cdot L_{e}
$$


O número de orientação $\left(\eta_{i}\right)$ e a contribuição relativa $\left(C_{i}\right)$ das fibras em relação ao eixo i são dados pelas Equações 3.2 e 3.3, respectivamente, onde: $\alpha_{\mathrm{i}}$ é o ângulo formado entre a orientação média das fibras e o eixo i; $\gamma$ é o fator de aspecto da fibra de aço utilizada e $\theta$ e $\mu$ são fatores de correção devido a aleatoriedade das fibras no corpo de prova. O parâmetro $\gamma$ foi adotado $0,05, \beta \mathrm{v}$, i para um cubo de $100 \mathrm{~mm}$ de aresta é de 2,342 e os fatores $\theta$ e $\mu$ são 1,03 e 0,1, respectivamente (CAVALARO et al., 2015).

$$
\begin{gathered}
\cos \alpha_{i}=\eta_{i}=\theta \cdot \sqrt{\frac{L_{i}(1+2 \gamma)-L_{e} B_{v, i} \gamma}{L_{e} B_{v, i}(1-\gamma)}}-\mu \\
C_{i}=\frac{\eta_{i}}{\sum_{i=x, y, z} \eta_{i}}
\end{gathered}
$$

$\mathrm{O}$ parâmetro $\mathrm{C}_{\mathrm{i}}$ mensura a contribuição das fibras orientadas em paralelo ao eixo "i" analisado para variação total da indutância aferida. As fibras, quando em paralelo às linhas do campo magnético, apresentam permeabilidade magnética máxima, apresentando elevada contribuição na variação da indutância. Por fim, os valores de massa das fibras foram calculados e, relacionando com o volume de cada cubo analisado, foram obtidos os teores reais de fibras $\left(\mathrm{kg} / \mathrm{m}^{3}\right)$ de cada grupo de amostras.

Tornou-se possível, então, relacionar a resistência residual obtida por meio do ensaio DEWS com a orientação média e a distribuição das fibras de aço nos cubos de concreto. Esta relação é essencial para interpretar e esclarecer o comportamento mecânico do compósito, sobretudo no que se refere à sua resistência à tração. Deste modo, a realização dos ensaios em conjunto proporciona uma melhor caracterização e um controle mais apurado do CRFA.

\subsubsection{Perda de massa e módulo de elasticidade dinâmico}

De acordo com Mehta e Monteiro (2008), o módulo de elasticidade dinâmico corresponde a uma deformação instantânea muito pequena e é, cerca de 20, 30 e 40\% mais alto do que o módulo estático para concretos de alta, média e baixa resistência, respectivamente.

Ao aplicar o método do ultrassom, conhecendo a distância entre os transdutores - que corresponde à altura da amostra - e o tempo decorrido entre a emissão e recepção do pulso, pode-se obter uma velocidade média da propagação da onda ultrassônica que, de acordo com Chies (2014), depende diretamente da densidade, das propriedades elásticas do material e, 
principalmente, da qualidade do concreto. Sendo assim, além do módulo de elasticidade dinâmico, os valores de massa e densidade das amostras também foram determinados.

O ensaio não destrutivo para determinação do módulo de elasticidade dinâmico foi realizado com a utilização do equipamento Proceq Pundit Lab, conforme as orientações da NBR 8802 (ABNT, 2019), por meio da determinação da velocidade de propagação de ondas longitudinais, obtidas por pulsos ultrassônicos (Figura 3.20). Transdutores com $20 \mathrm{~mm}$ de diâmetro foram utilizados em uma frequência de $200 \mathrm{kHz}$. O ensaio foi empregado a fim de detectar alterações em termos de porosidade e fissuras decorrentes da deterioração causada pela exposição do compósito a elevadas temperaturas. O módulo de elasticidade dinâmico é calculado por:

$$
E_{c}=\frac{\rho \cdot V^{2} \cdot(1+v) \cdot(1-2 v)}{1-v}
$$

Onde $\rho$ é a densidade do CRFA $\left(\mathrm{em} \mathrm{kg} / \mathrm{m}^{3}\right) ; \mathrm{V}$ é a velocidade de propagação do pulso ultrassônico (em km/s); v é o coeficiente de Poisson. A densidade do compósito foi calculada tomando como base os valores de massa e volume das amostras para cada temperatura analisada. O coeficiente de Poisson foi assumido constante e igual a 0,2 para todas as temperaturas-alvo, visto que se trata de uma propriedade que não se altera de forma significativa para pequenos valores de tensão (SCHNEIDER, 1988).

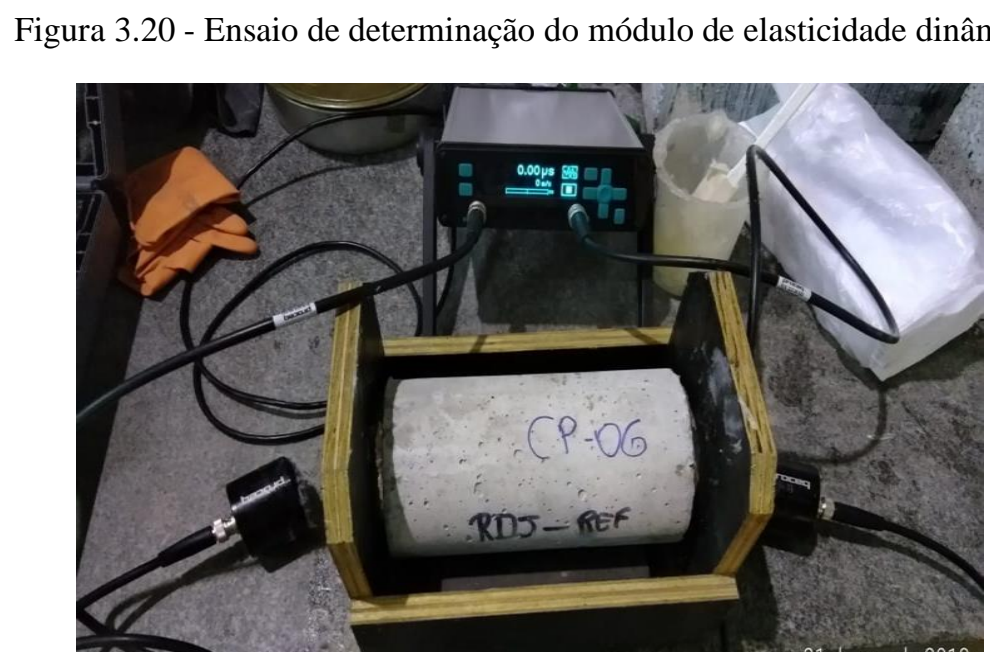

Fonte: Acervo do autor

Os valores de massa, densidade e módulo de elasticidade dinâmico foram determinados nas mesmas amostras cilíndricas antes e após exposição às temperaturas específicas (150, 300, 450, 600 e $750{ }^{\circ} \mathrm{C}$ ), em uma etapa prévia à avaliação por meio de ensaios mecânicos. 


\subsection{Avaliação do CRFA por meio de ensaios mecânicos}

A Tabela 3.6 sintetiza os ensaios mecânicos empregados neste estudo, antes e após os procedimentos de aquecimento descritos previamente.

Tabela 3.6 - Ensaios mecânicos conduzidos neste estudo

\begin{tabular}{|c|c|c|c|c|}
\hline Ensaio & Propriedade & $\begin{array}{l}\text { Procedimento de } \\
\text { aquecimento }\end{array}$ & Forma da amostra & $\begin{array}{c}\text { Número de } \\
\text { amostras }\end{array}$ \\
\hline \multirow{4}{*}{$\begin{array}{l}\text { Ensaios de } \\
\text { compressão }\end{array}$} & Resistência à & Forno elétrico & Cilíndrica & \multirow{4}{*}{$72^{(1)}$} \\
\hline & compressão & $25-750^{\circ} \mathrm{C}$ & $(\varnothing 100 \times 200$ mm) & \\
\hline & Módulo de & Forno elétrico & Cilíndrica & \\
\hline & elasticidade & $25-750^{\circ} \mathrm{C}$ & $(\varnothing 100 \times 200 \mathrm{~mm})$ & \\
\hline \multirow{3}{*}{ Ensaio DEWS } & Propriedades de & Forno elétrico & Cúbica & \multirow{2}{*}{$180^{(2)}$} \\
\hline & tração & $25-750^{\circ} \mathrm{C}$ & $(100 \times 100 \times 100 \mathrm{~mm})$ & \\
\hline & $\begin{array}{c}\text { Propriedades de } \\
\text { tração }\end{array}$ & $\begin{array}{l}\text { Exposição ao fogo } \\
\text { (Curva "H") }\end{array}$ & $\begin{array}{c}\text { Cúbica } \\
(100 \times 100 \times 100 \mathrm{~mm})\end{array}$ & $60^{(3)}$ \\
\hline Ensaio de flexão & $\begin{array}{c}\text { Propriedades de } \\
\text { tração }\end{array}$ & $\begin{array}{l}\text { Exposição ao fogo } \\
\text { (Curva “H”) }\end{array}$ & $\begin{array}{c}\text { Prismática } \\
(100 \times 100 \times 350 \mathrm{~mm})\end{array}$ & $24^{(4)} *$ \\
\hline $\begin{array}{l}\text { (1) } 4 \text { amostras pc } \\
\text { (2) } 10 \text { amostras } 1 \\
\text { (3) } 10 \text { amostras } 1 \\
\text { (4) } 4 \text { amostras pc }\end{array}$ & $\begin{array}{l}\text { or de fibra de aço } \\
\text { teor de fibra de açc } \\
\text { teor de fibra de açc } \\
\text { or de fibra de aço }\end{array}$ & $\begin{array}{l}\text { ra as temperaturas de } \\
\text { ara as temperaturas de } \\
\text { ara a temperatura amb } \\
\text { ra a temperatura ambi }\end{array}$ & $\begin{array}{l}5,150,300,450,600 \\
25,150,300,450,600 \\
\text { iente e após exposição } \\
\text { nte e após exposição a }\end{array}$ & $\begin{array}{l}{ }^{\circ} \mathrm{C} \\
0{ }^{\circ} \mathrm{C} \\
g o\end{array}$ \\
\hline
\end{tabular}

\subsubsection{Resistência à compressão e módulo estático de elasticidade}

Após o procedimento completo de aquecimento em mufla nas temperaturas específicas, os corpos de prova cilíndricos foram submetidos aos ensaios de resistência à compressão, preconizado pela NBR 5739 (ABNT, 2018), e de determinação dos módulos estáticos de elasticidade e de deformação à compressão, conforme NBR 8522 (ABNT, 2017). Os ensaios foram realizados utilizando taxa constante de $0,5 \mathrm{MPa} / \mathrm{s}$ em uma máquina de ensaio universal servo-hidráulica da marca SHIMADZU, modelo UH-2000kNXR, que opera com uma frequência de $60 \mathrm{~Hz}$ e possui capacidade de carga de $2000 \mathrm{kN}$, além de sistema de retroalimentação. Com isso, obteve-se também as curvas tensão-deformação à compressão.

Para o ensaio de módulo de elasticidade, as amostras foram posicionadas de forma centralizada e submetidas a apenas um carregamento e descarregamento sucessivo (Figura 3.21). O ciclo usual de três carregamentos não foi adotado, visto que as amostras foram severamente degradadas pela temperatura. Assim, foi aplicado um plano de carga variando de $0,5 \mathrm{MPa}$ até $30 \%$ da carga última $\left(0,3 \mathrm{f}_{\mathrm{c}}\right)$, determinada previamente em dois corpos de prova 
ensaiados a compressão axial. Foram utilizados dois transdutores do tipo LVDT (Linear Variable Displacement Transducer), posicionados em anéis metálicos ao redor das amostras, para medição dos deslocamentos lineares, com o objetivo de determinar a deformação axial e o módulo estático de elasticidade do CRFA.

Foram ensaiadas 4 amostras cilíndricas (diâmetro de $100 \mathrm{~mm}$ e altura de $200 \mathrm{~mm}$ ) por teor de fibra de aço, destinadas à avaliação nas temperaturas de $25,150,300,450,600$ e $750{ }^{\circ} \mathrm{C}$. Uma vez que os teores analisados permaneceram os mesmos $\left(20,35\right.$ e $\left.70 \mathrm{~kg} / \mathrm{m}^{3}\right)$, um total de 72 cilindros foram ensaiados por estes métodos. Esses ensaios não foram aplicados em amostras expostas ao fogo devido à extensa degradação superficial e à heterogeneidade de propriedades mecânicas induzidas em seu interior quando submetidas a esse procedimento de aquecimento.

Figura 3.21 - Determinação do módulo estático de elasticidade do CRFA

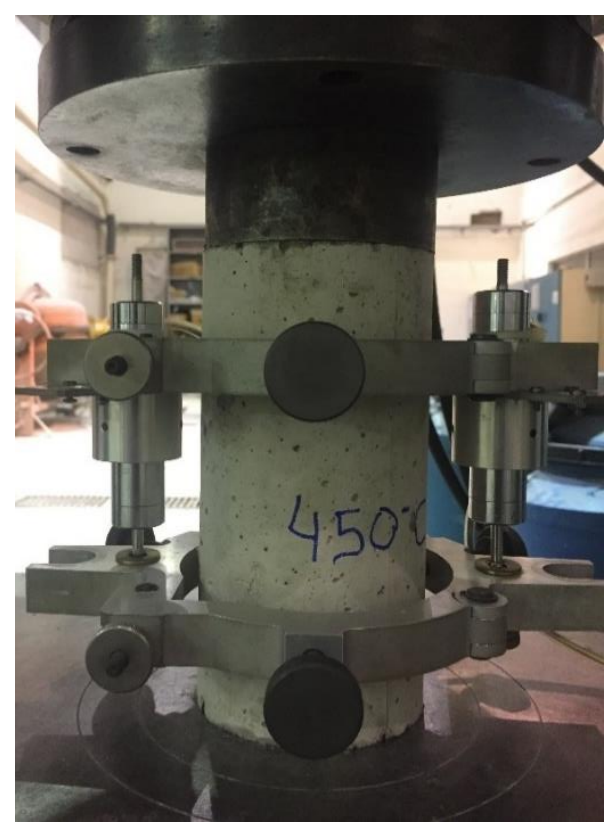

Fonte: Acervo do autor

\subsubsection{Ensaio DEWS}

Por meio do ensaio DEWS (Double Edge Wedge Splitting), desenvolvido por di Prisco et al. (2013), é possível avaliar a ruptura do material a esforços de tração gerados de forma indireta, por meio da aplicação de esforços de compressão em um corpo de prova com cunhas e entalhes em duas faces opostas. Uma fratura tipo I é obtida e, assim, a relação tensão - deformação é obtida de forma direta. O ensaio foi executado a fim de se obter a resistência à tração e a resistência à tração pós-fissuração nas diferentes temperaturas de ensaio, caracterizando a progressão dos danos nas diferentes camadas do CRFA provocados pela exposição ao fogo. O 
procedimento de ensaio adotado seguiu a metodologia simplificada proposta por Borges et al. (2019), como apresentado na Figura 3.22. O ensaio foi empregado para avaliar as propriedades de tração de amostras cúbicas submetidas a elevadas temperaturas quando aquecidas em forno elétrico ou por meio do ensaio de exposição unifacial ao fogo. A Figura 3.22a apresenta um desenho esquemático da configuração do ensaio DEWS adotada neste estudo.

Figura 3.22 - (a) Desenho esquemático do ensaio DEWS; (b) Setup do ensaio DEWS adotado neste estudo

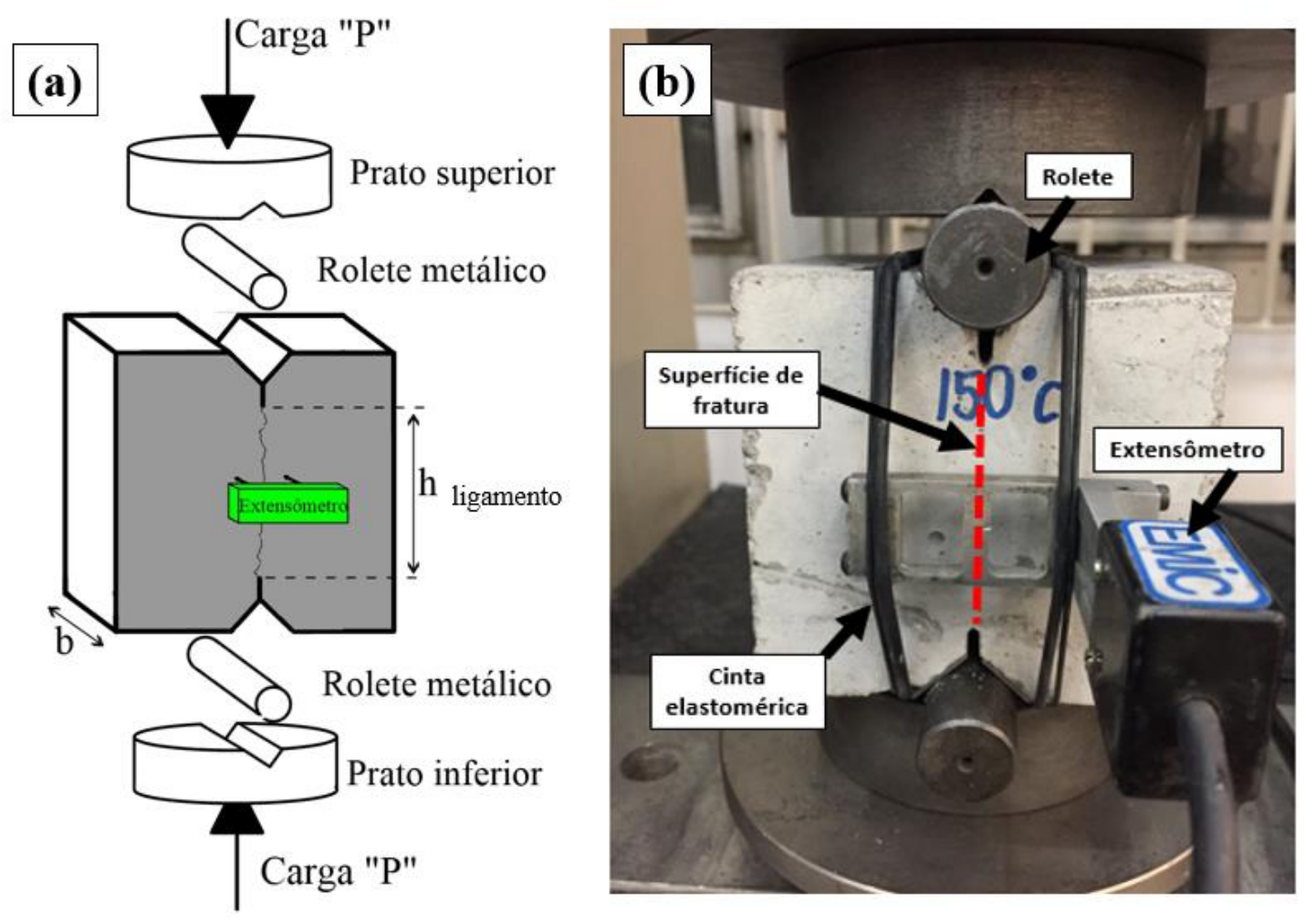

Fonte: Elaborado pelo autor

Após o aquecimento das amostras em forno elétrico nas diferentes temperaturas de ensaio e o subsequente período de resfriamento, chapas metálicas de dimensões $0,9 \times 15 \times 100 \mathrm{~mm}$ (espessura $\mathrm{x}$ largura x comprimento) foram fixadas nas superfícies das cunhas com a utilização de adesivo plástico pastoso à base de resina de poliéster insaturado (massa plástica adesiva). As chapas de aço são usadas para reduzir a interação de atrito entre o rolete de aço e a superfície do corpo de prova durante o ensaio. Além disso, em cada amostra, aplicou-se grafite em pó para lubrificar a superfície de contato entre o rolete e a as chapas metálicas, o que contribui para o aumento da confiabilidade dos resultados, como demonstrado por di Prisco et al. (2013). Apesar da superfície das amostras se apresentar bastante degradada devido à ação deletéria da temperatura, não houve dificuldade em colar as chapas, assim como não ocorreu o descolamento destas durante o ensaio, de forma que o material utilizado para este fim atendeu às necessidades solicitadas. 
Os ensaios foram realizados utilizando uma velocidade de carregamento de $0,12 \mathrm{~mm} / \mathrm{min}$ em uma máquina eletromecânica EMIC, modelo DL 10000, com rigidez de quadro de 42 $\mathrm{kN} / \mathrm{mm}$, célula de carga com capacidade de $10 \mathrm{kN}$ e em sistema aberto de controle de velocidade. Diferentemente do que ocorre no sistema fechado, que utiliza a deformação medida do corpo de prova para regular o aparelho de carregamento a fim de obter uma resposta direto da amostra, no sistema aberto há ausência do mecanismo de retroalimentação (“feedback”), o que impede que o carregamento seja imposto por parâmetros pré-definidos. A velocidade de carregamento foi adotada tomando como base o estudo de Borges et al. (2019), que concluiu que é possível utilizar uma taxa maior que a adotada por di Prisco et al. (2013) sem que haja prejuízos aos valores obtidos como resposta do material.

Dois extensômetros de garras, com base de medida de $50 \mathrm{~mm}$, foram fixados com cintas elastoméricas em faces opostas da amostra cúbica, na altura média e perpendicularmente ao plano de fratura. Os valores diretos de abertura de fissura (crack opening displacement - COD) registrados são dados pela média aritmética das medições obtidas em faces opostas da amostra e foram registrados pelo software Tesc.

A carga é aplicada na amostra de CRFA por meio de um rolete metálico diretamente acomodado nas chapas metálicas. Essa carga imposta pela máquina não pode ser considerada como a carga que atua na superfície de fratura da amostra. Através das cunhas triangulares, a carga de compressão aplicada pela máquina é desviada, induzindo um estado de tensão de tração uniaxial no ligamento (região entre os entalhes) e uma superfície de fratura vertical. Considerando as equações de equilíbrio, o valor de carga do equipamento $(P)$ é convertido em carga efetiva $\left(P_{e f}\right)$ - que atua na superfície de fratura - por meio da seguinte equação:

$$
P_{e f}=P \cdot \frac{(\cos \theta-\mu \sin \theta)}{(\sin \theta+\mu \cos \theta)}
$$

Onde $\theta$ é o ângulo entre a superfície da cunha e a linha central do entalhe $\left(\theta=45^{\circ}\right)$ e $\mu$ é o coeficiente de atrito entre duas superfícies de aço lubrificadas com grafite em pó $(\mu=0,06)$. A tensão de tração é determinada com base na Equação 3.6, proposta por di Prisco et al. (2013), onde $b$ é a profundidade da amostra e $h_{\text {lig }}$ é a altura do ligamento.

$$
\sigma=\frac{P_{e f}}{b \cdot h_{l i g}}
$$


Os valores de resistência à tração pós-fissuração associados ao estado limite de serviço $\left(f_{t 0,25}\right)$ e estado limite último $\left(f_{t 1,25}\right)$ foram adotados com base nas aberturas de fissura (COD) de $0,25 \mathrm{~mm}$ e 1,25 mm, respectivamente. Esses valores foram estimados com base nas diferenças geométricas em termos de configuração de ensaio e padrão de abertura de fissura entre ensaios de flexão e o ensaio DEWS, procurando-se garantir uma abertura de fissura média equivalente.

Um total de 10 amostras cúbicas (100x100x100 mm) por teor de fibra de aço $(20,35$ e 70 $\mathrm{kg} / \mathrm{m}^{3}$ ) foram ensaiadas para cada uma das seguintes temperaturas: $150,300,450,600$ e $750{ }^{\circ} \mathrm{C}$, além da temperatura ambiente $\left(\sim 25^{\circ} \mathrm{C}\right)$. Assim, 180 amostras cúbicas aquecidas em forno elétrico foram ensaiadas por este método. Também foram ensaiadas por meio do ensaio DEWS amostras cúbicas extraídas de amostras prismáticas expostas ao fogo e ensaiadas à flexão. Foram ensaiadas 10 amostras por teor de fibra de aço para cada uma das seguintes condições: à temperatura ambiente $\left(\sim 25^{\circ} \mathrm{C}\right)$ sem exposição ao fogo e após exposição ao fogo. Logo, 60 amostras cúbicas expostas ao fogo foram ensaiadas por este método. A Figura 3.23 ilustra a configuração do ensaio DEWS para as amostras expostas ao fogo.

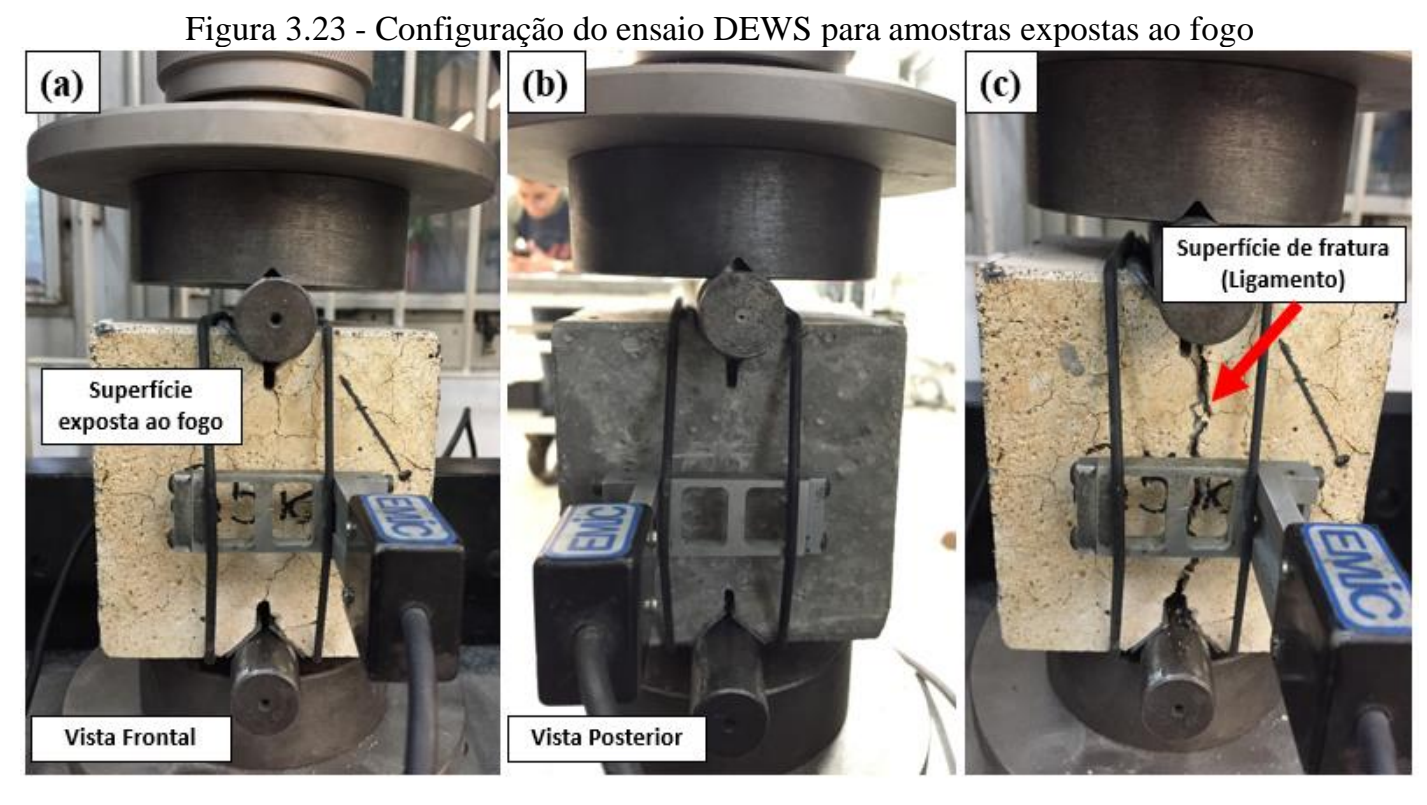

Fonte: Acervo do autor

Os resultados obtidos na caracterização mecânica do CRFA por meio do ensaio DEWS foram estatisticamente analisados por meio da análise de variância (ANOVA) e teste de Tukey. A relação entre o tamanho amostral e o erro admissível para o ensaio DEWS foi determinada com base em conceitos de estatística inferencial e por meio da Equação 3.7.

$$
n=\frac{s^{2} \cdot \mathrm{z}_{\gamma}^{2}}{\varepsilon^{2}}
$$


Onde $n$ é o número de amostras necessários; $s$ é o desvio padrão obtido pela amostra piloto (em MPa); $z_{\gamma}$ é o valor da distribuição t de Student; e $\varepsilon$ é o erro admissível para o ensaio. Os valores de média e desvio padrão foram determinados a partir dos resultados experimentais, enquanto $z_{\gamma}=2,132$ foi adotado considerando um intervalo de confiança de $95 \%$ e 4 graus de liberdade.

\subsubsection{Determinação da resistência à tração na flexão}

As amostras prismáticas de dimensões 100x100x350 mm foram avaliadas por seu comportamento mecânico, de modo que foram submetidas ao ensaio de flexão de 3 pontos adaptado da norma EN 14651 (2007), à temperatura ambiente e após exposição ao fogo. Esse ensaio determina a resistência à tração por meio da flexão do compósito, de forma que caracteriza as resistências residuais para determinadas aberturas de fissuras, assim como o limite de proporcionalidade. Dessa forma, é possível verificar o efeito da temperatura em termos de resistência à tração na flexão, estabelecendo a diferença entre os comportamentos mecânicos do CRF submetido ao fogo e à temperatura ambiente para diferentes teores de fibras de aço.

Para o ensaio de flexão adaptado da EN 14651 (2007) foram destinadas 4 amostras prismáticas por teor de fibra de aço. Visto que os teores analisados permanecem os mesmos $\left(20,35\right.$ e $\left.70 \mathrm{~kg} / \mathrm{m}^{3}\right)$, e a verificação foi feita à temperatura ambiente e após o ensaio de exposição unifacial ao fogo, um total de 24 prismas foram ensaiados por este método.

Os ensaios foram realizados em uma máquina servo-hidráulica INSTRON 8802 (Figura 3.24), com capacidade de carga de $250 \mathrm{kN}$, operando em circuito fechado de controle da velocidade de ensaio (closed-loop). O equipamento de ensaio possuía capacidade de resposta suficiente para evitar zonas de instabilidade na curva força-CMOD (termo originado do inglês “crack mouth opening displacement"). A máquina é equipada com um dispositivo de flexão que assegurava a aplicação da força perpendicularmente às faces superior e inferior da amostra, sem excentricidades. Adotou-se a configuração de controle por meio da medida da abertura do entalhe na face inferior do corpo de prova (CMOD), utilizando um clip-gauge com abertura máxima de $4 \mathrm{~mm}$, capaz de medir deslocamentos com precisão de 0,001 mm. Esse transdutor de deslocamento foi posicionado ao longo do eixo longitudinal no meio da largura do corpo de prova, como demonstrado na Figura 3.25, de modo que a distância entre a parte inferior da amostra e a linha de medição fosse menor que $5 \mathrm{~mm}$. 
Figura 3.24 - Setup do ensaio de flexão de 3 pontos: (a) visão geral; (b) amostra ensaiada sem exposição ao fogo; (c) amostra ensaiada após exposição ao fogo

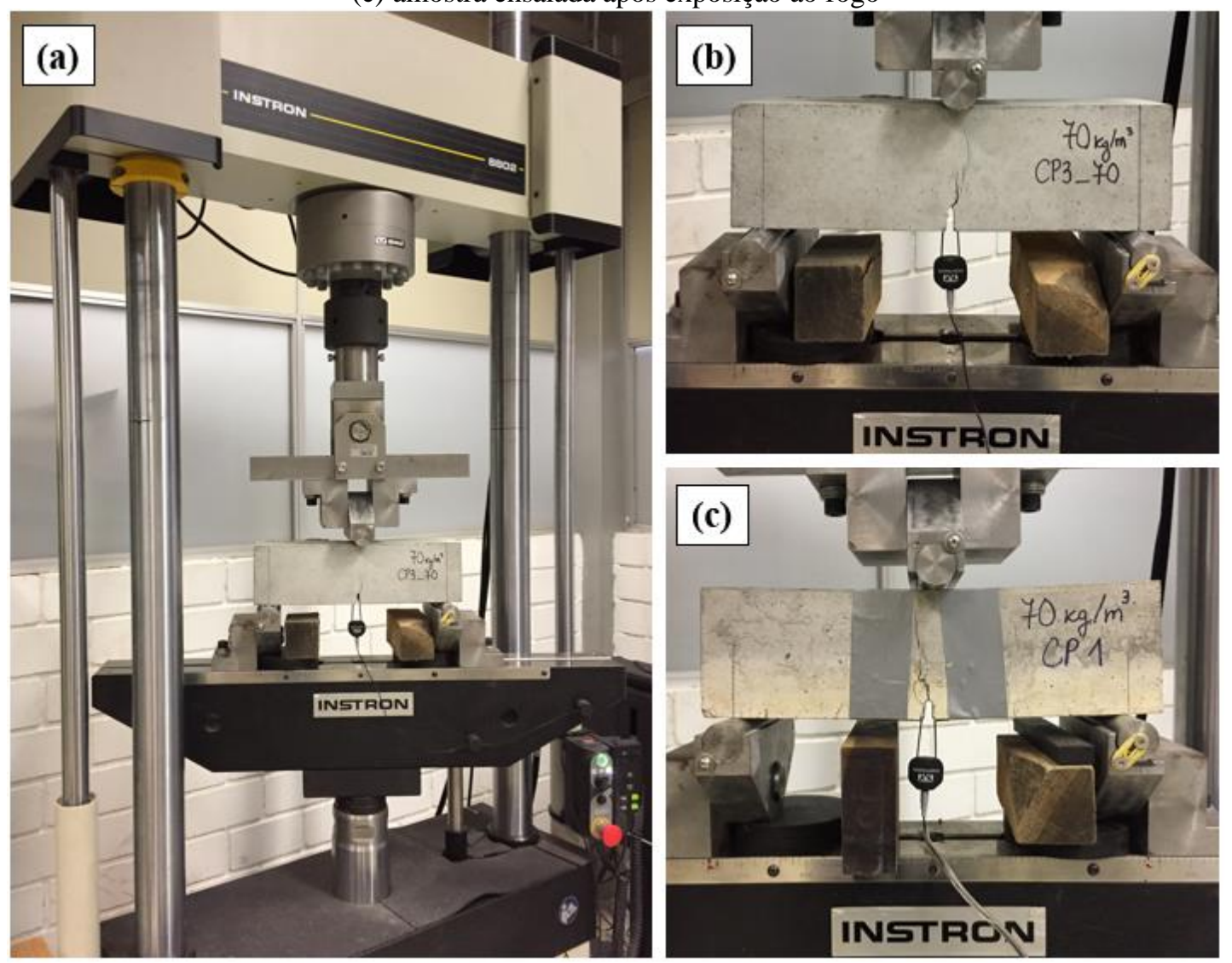

Fonte: Acervo do autor

Figura 3.25 - Posicionamento do clip-gauge no ensaio de flexão de 3 pontos: (a) amostra ensaiada sem exposição ao fogo; (b) amostra ensaiada após exposição ao fogo

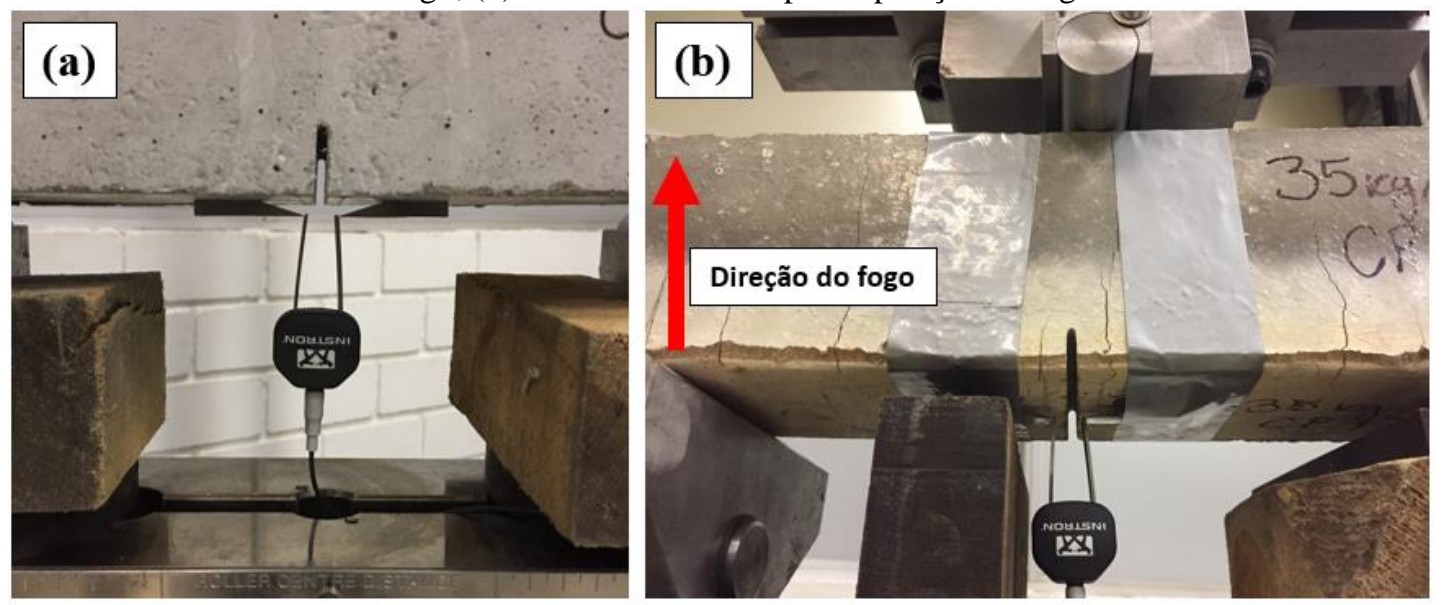

Fonte: Acervo do autor

Vale ressaltar que as amostras prismáticas possuíam dimensões menores que as preconizadas pelo ensaio da EN 14651 (2007), o que acarretou adaptações na metodologia do ensaio. Os roletes eram de aço, possuíam seção circular com diâmetro de $30 \mathrm{~mm}$ e comprimento maior que a largura da amostra prismática. Para cada amostra ensaiada, as superfícies dos 
roletes eram limpas e mantidas lisas. A distância entre os centros dos roletes de suporte (vão de ensaio) foi igual a $300 \mathrm{~mm}$ (Figura 3.26), de modo que cada rolete ficou localizado a $25 \mathrm{~mm}$ de cada face lateral do corpo de prova. Antes de iniciar o ensaio, o comprimento de vão médio dos corpos de prova foi determinado a partir de duas medições entre os eixos dos roletes de apoio em ambos os lados das amostras.

Os corpos de prova possuíam entalhe de $5 \mathrm{~mm}$ de espessura, que foram produzidos após exposição ao fogo, com auxílio de disco apropriado para concreto, à seco, e com extrema cautela, visto que as superfícies se encontravam degradadas e friáveis. Os corpos de prova foram girados em $90^{\circ} \mathrm{em}$ torno de seu eixo longitudinal e depois cortados na sua largura, no meio do vão (Figura 3.26). A altura do entalhe também foi modificada e passou a ser de (17 \pm 1$) \mathrm{mm}$, de modo que a distância entre o topo do entalhe e o topo do corpo de prova $\left(\mathrm{h}_{\mathrm{sp}}\right)$ foi de $(83 \pm 1)$ $\mathrm{mm}$, visando manter a proporção com amostras de $150 \mathrm{~mm}$ de altura, cujo valor de $\mathrm{h}_{\mathrm{sp}}$ é de 125 $\mathrm{mm}$.

As dimensões das amostras foram determinadas com o uso de paquímetro, com resolução de $0,1 \mathrm{~mm}$. A dimensão $\mathrm{h}_{\mathrm{sp}}$ e a largura média das amostras (b) foram determinadas pela média de duas medições, nas duas faces do corpo de prova. As amostras foram posicionadas na máquina de ensaios e corretamente centradas, com seus eixos longitudinais formando ângulos retos com os eixos longitudinais dos roletes inferiores (de apoio) e superior (de carga). Não foi realizado nenhum método de regularização da superfície do corpo de prova, pois suas faces já se apresentam suficientemente regulares, inclusive após exposição ao fogo. A carga somente foi aplicada quando todos os roletes estavam uniformemente apoiados contra o corpo de prova.

Figura 3.26 - Arranjo do ensaio de flexão empregado e posição do entalhe na seção da amostra prismática
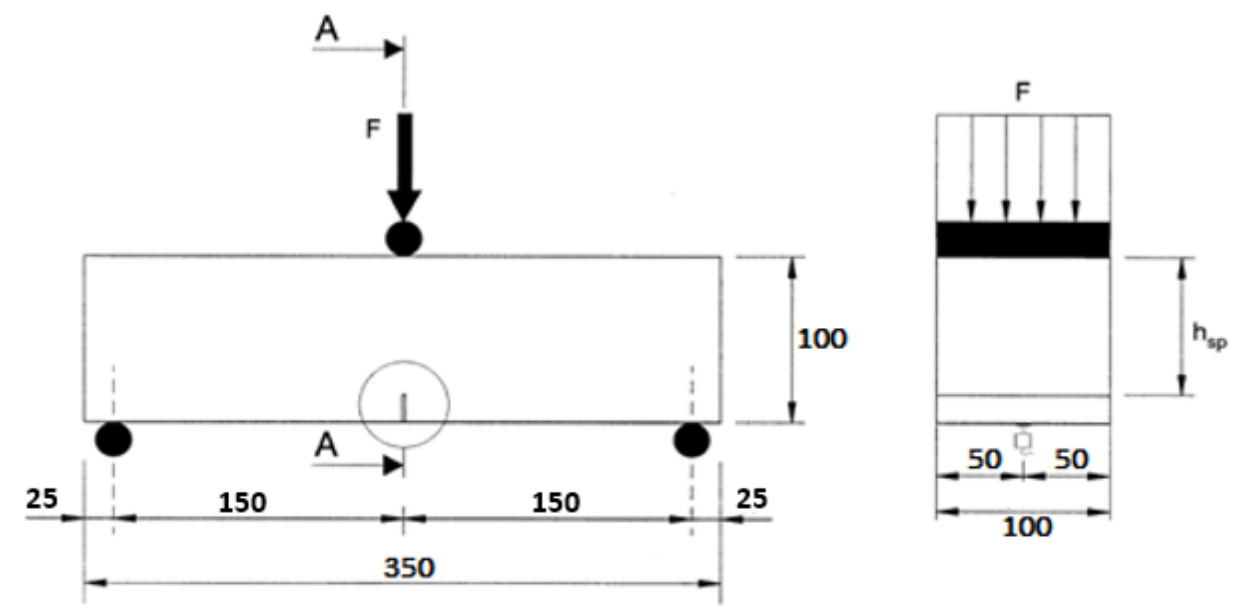

section A-A 


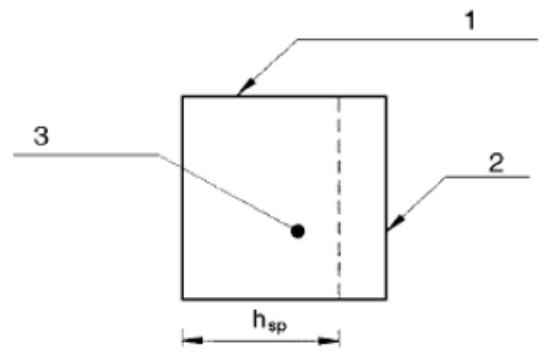

\section{Legenda}

1) Superfície durante a moldagem

2) Entalhe

3) Seção transversal da amostra prismática

Fonte: Adaptado de EN 14651 (2007)

O equipamento de ensaio foi operado de modo que o CMOD aumentou a uma taxa constante de $0,05 \mathrm{~mm} / \mathrm{min}$ até $\mathrm{CMOD}=0,1 \mathrm{~mm}$. Atingida esta abertura de entalhe, $\mathrm{o}$ equipamento foi operado de modo que o CMOD aumentou a uma taxa constante de $0,2 \mathrm{~mm} / \mathrm{min}$ até a finalização do ensaio. A adoção de uma taxa menor no trecho inicial tem a função de minimizar a ocorrência da instabilidade pós-pico. O ensaio foi encerrado com um valor de CMOD igual a $4 \mathrm{~mm}$. Os valores da carga e correspondentes CMOD foram registrados a uma taxa superior a $5 \mathrm{~Hz}$. Quando durante a realização do ensaio a fissura iniciasse fora do entalhe, em ambos os lados, o ensaio seria descartado.

A resistência à tração do CRFA (Limite de Proporcionalidade - LOP) consiste na tensão na extremidade superior do entalhe calculada a partir de uma carga máxima aplicada no meio do vão, para um valor de CMOD contido no intervalo de 0 a $0,05 \mathrm{~mm}$, assumida em uma seção não fissurada $\left(\mathrm{F}_{\mathrm{L}}\right)$. O LOP foi determinado pela equação a seguir:

$$
f_{L O P}=\frac{3 \cdot F_{L} \cdot l}{2 \cdot b \cdot h_{s p}^{2}}
$$

Onde:

$f_{L O P}$ é o LOP, expresso em newtons por milímetro quadrado $\left(\mathrm{N} / \mathrm{mm}^{2}\right)$;

$F_{L}$ é a carga correspondente ao LOP, expressa em newtons (N);

$l$ é o comprimento do vão de ensaio, expresso em milímetros (mm);

$b$ é a largura do corpo de prova, expressa em milímetros (mm);

$h_{s p}$ é a distância entre o topo do entalhe e o topo da amostra, expressa em milímetros (mm).

O valor de $F_{L}$ foi determinado no gráfico com uma linha paralela ao eixo do carregamento a uma distância de $0,05 \mathrm{~mm}$ no diagrama de carregamento versus CMOD. Adotou-se para $F_{L}$ O valor da carga máxima no intervalo de 0 a $0,05 \mathrm{~mm}$. 
As resistências residuais (pós-fissuração) à tração na flexão, $f_{R, i}$, foram obtidas a partir da curva Força-CMOD, pela seguinte expressão:

$$
f_{R, i}=\frac{3 \cdot F_{i} \cdot l}{2 \cdot b \cdot h_{s p}^{2}}
$$

Onde:

$f_{R, i}$ é a resistência residual (pós-fissuração) à tração na flexão correspondente ao CMOD $=$ CMODi $($ com i $=1,2,3,4)$, expressa em newtons por milímetro quadrado $\left(\mathrm{N} / \mathrm{mm}^{2}\right)$;

$F_{i}$ é a carga correspondente ao CMOD $=$ CMODi $(\mathrm{i}=1,2,3,4)$, expressa em newtons $(\mathrm{N})$, como ilustrado na Figura 3.27;

$l$ é o comprimento do vão de ensaio, expresso em milímetros ( $\mathrm{mm})$;

$b$ é a largura do corpo de prova, expressa em milímetros (mm);

$h_{s p}$ é a distância entre o topo do entalhe e o topo da amostra, expressa em milímetros (mm).

Figura 3.27 - Diagrama típico de força versus CMOD, identificando as cargas residuais

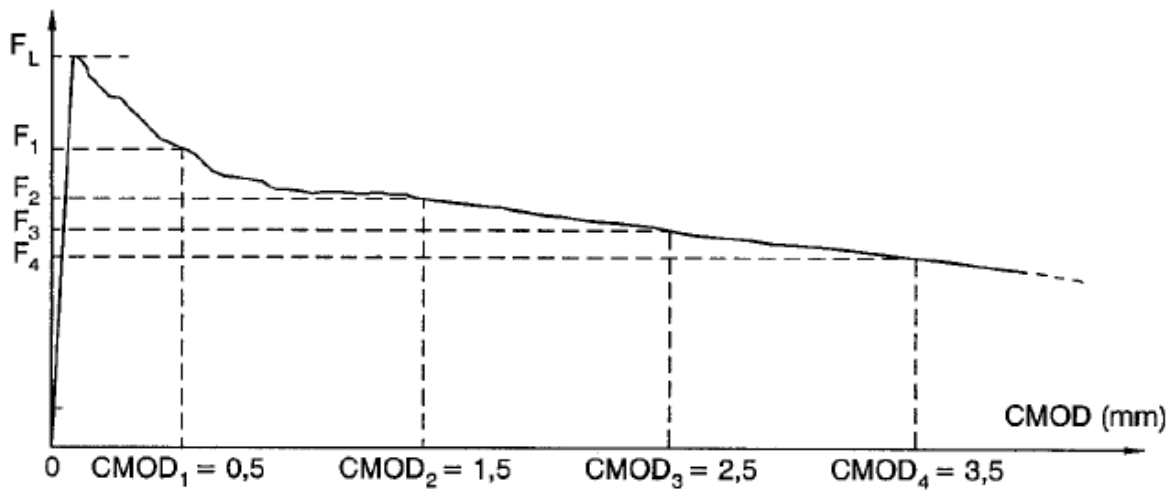

Fonte: Adaptado de EN 14651 (2007)

Assume-se que as resistências residuais à tração para $\mathrm{CMOD}=0,5 \mathrm{~mm}$ (identificada como $f_{R 1}$ ) e 2,5 mm (identificada como $f_{R 3}$ ) estão associadas ao Estado Limite de Serviço (ELS) e ao Estado Limite Último (ELU) da estrutura, respectivamente, e são os principais parâmetros utilizados para dimensionamento (di PRISCO; PLIZZARI; VANDEWALLE, 2009).

Por fim, as amostras prismáticas que foram submetidas ao fogo e as que não foram, após ensaiadas à flexão, tiveram suas extremidades cortadas em amostras cúbicas, as quais foram destinadas ao ensaio DEWS. A preparação das amostras cúbicas, com cortes em cunhas e entalhes, seguiu o mesmo procedimento descrito na Seção 3.3. Respeitou-se a mesma orientação das amostras aquecidas em forno. 


\section{RESULTADOS E DISCUSSÕES}

\subsection{Caracterização mineralógica}

A Figura 4.1 apresenta os resultados de DRX para pastas de cimento expostas a temperaturas-alvo avaliadas neste estudo. A Tabela 4.1 sintetiza os processos químicos e físicos originados pelo aumento da temperatura, associados aos resultados de DRX. Percebe-se que a elevação da temperatura promove a decomposição dos produtos hidratados, o que acarreta redução da área superficial específica dos hidratos e incremento da porosidade da pasta de cimento (GALLUCCI et al., 2013). Além disso, esse processo também contribui para a geração de pequenas fissuras que se sobrepõem às fissuras maiores geradas por tensões internas, como as formadas pela expansão térmica dos agregados ou induzidas por gradientes de temperatura (SERAFINI et al., 2019a).

Figura 4.1 - Composição mineralógica de pastas de cimento expostas a temperaturas elevadas

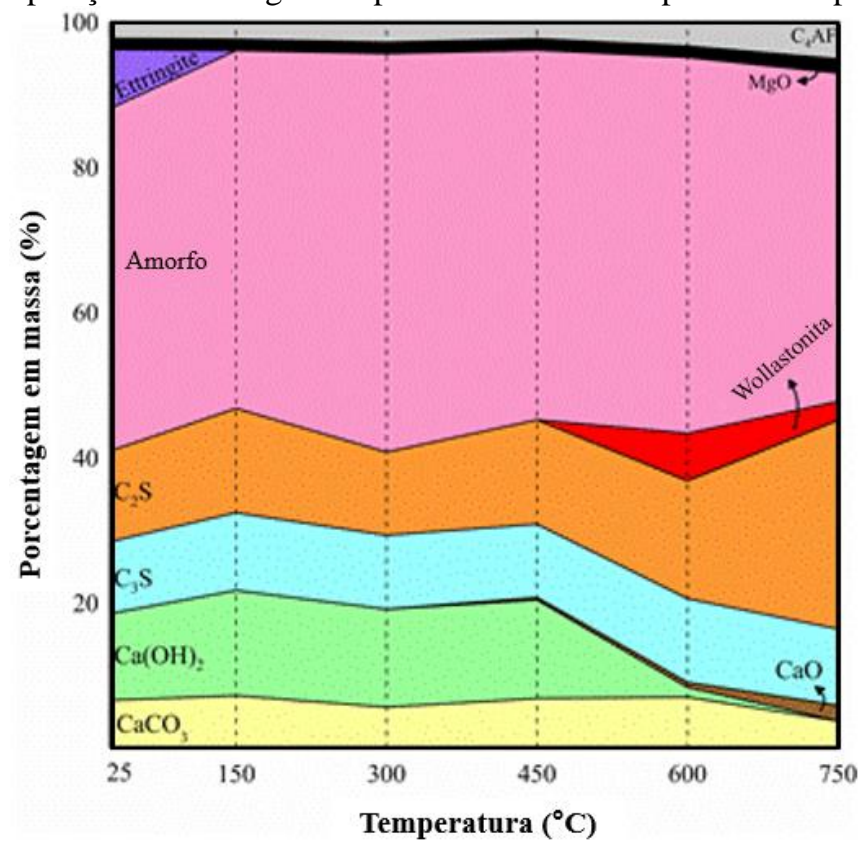

Fonte: Elaborado pelo autor

Os cristais de etringita desidratam na faixa de temperatura de 25 e $150^{\circ} \mathrm{C}$, os quais fissuram e perdem o grau de cristalinidade à medida que apresentam redução das moléculas de água $\left(\mathrm{H}_{2} \mathrm{O}\right)$ de 32 para 18 em sua composição (SKOBLINSKAYA; KRASILNIKOV, 1975). A desidratação da etringita é responsável pelo aumento do teor de material amorfo $(\sim 4,5 \%)$ verificado nos resultados de DRX nesta faixa de temperatura.

Os resultados de DRX indicam que na faixa de temperatura entre 150 e $300{ }^{\circ} \mathrm{C}$ há decomposição do gel C-S-H em belita $\left(\mathrm{C}_{2} \mathrm{~S}\right)$. Entretanto, as propriedades cristalográficas e o 
perfil dos picos de DRX apresentados nos difratogramas indicam que esses nesossilicatos formados após exposição à temperatura diferem daqueles encontrados no pó de cimento anidro, como verificado na literatura (SERAFINI et al., 2019a; RAI, 2012). Além disso, essa diferença inerente da estrutura cristalina pode resultar em alterações em termos de atividade hidráulica desse silicato, o que pode afetar significativamente a cinética de reidratação.

Tabela 4.1 - Síntese das mudanças mineralógicas em função da temperatura

\begin{tabular}{|c|c|}
\hline $\begin{array}{c}\text { Intervalo de } \\
\text { temperatura }\left({ }^{\circ} \mathrm{C}\right)\end{array}$ & Alterações na microestrutura \\
\hline $25-150$ & $\begin{array}{l}\text { Decomposição inicial do C-S-H. A etringita é completamente desidratada, } \\
\text { resultando em um aumento no teor total de material amorfo. }\end{array}$ \\
\hline $150-300$ & $\begin{array}{l}\text { A decomposição do gel C-S-H proporciona aumento no teor total de belita. O } \\
\text { teor amorfo atinge seu valor máximo. }\end{array}$ \\
\hline $300-450$ & $\begin{array}{l}\text { O C-S-H amorfo se decompõe em wollastonita, enquanto percebe-se um } \\
\text { aumento no teor de belita. A portlandita começa a desidratar e o teor de óxido de } \\
\text { cálcio aumenta levemente. }\end{array}$ \\
\hline $450-600$ & $\begin{array}{l}\text { O C-S-H se decompõe em belita e wollastonita. O teor de portlandita reduz } \\
\text { significativamente e o teor de óxido de cálcio aumenta. }\end{array}$ \\
\hline $600-750$ & $\begin{array}{l}\text { Decomposição do carbonato de cálcio, com o aumento significativo do teor de } \\
\text { óxido de cálcio. A desidratação do C-S-H resulta em aumento no teor de belita. }\end{array}$ \\
\hline
\end{tabular}

$\mathrm{Na}$ faixa de temperatura de 300 a $450{ }^{\circ} \mathrm{C}$ o processo de desidratação da portlandita é iniciado, o que aumenta o teor de óxido de cálcio. Além disso, a decomposição do gel C-S-H resulta na formação de wollastonita $\left(\mathrm{CaSiO}_{3}\right)$, que está associada à desidratação da jenita e tobermorita. Com o aumento da temperatura, as cadeias de silicato de jenita despolimerizam, perdem água entre camadas dos grupos $\mathrm{Si}-\mathrm{OH}$ e $\mathrm{Ca}-\mathrm{OH}$, e uma fase amorfa pode ser encontrada para temperaturas de até $600{ }^{\circ} \mathrm{C}$. A tobermorita permanece estável para temperaturas acima de $600{ }^{\circ} \mathrm{C}$ e a elevação de temperatura acarreta perda de água entre as camadas dos grupos $\mathrm{Si}-\mathrm{OH}$ (TAJUELO RODRIGUEZ et al., 2017).

Para temperaturas entre 450 e $750^{\circ} \mathrm{C}$, a desidratação da portlandita e a decomposição da calcita contribuem para o aumento do teor de óxido de cálcio nas amostras. A presença de calcita 
em amostras expostas à temperatura de $750{ }^{\circ} \mathrm{C}$ pode ser resultado de um processo de carbonatação que pode ter ocorrido durante a preparação e armazenamento das amostras. Essa breve exposição das amostras ao ambiente pode levar à rápida formação de carbonatos de cálcio, como apresentado na literatura (SCRIVENER et al., 2017). Essa formação, no entanto, não compromete os resultados deste estudo.

A desidratação da portlandita ocorre na mesma faixa de temperatura do C-S-H amorfo. Uma pequena quantidade de portlandita residual foi encontrada em amostras de pasta de cimento após exposição a temperaturas de $600{ }^{\circ} \mathrm{C}$, o que não era esperado, visto que a portlandita se desidrata em torno de $450{ }^{\circ} \mathrm{C}$ (TAYLOR, 1997). Essa quantidade residual pode estar associada à presença de água retida internamente devido ao tamanho e baixa porosidade da amostra. Ainda assim, a ausência de portlandita foi verificada em amostras expostas a 750 ${ }^{\circ} \mathrm{C}$, o que pode indicar que a quantidade residual de portlandita não foi formada durante a preparação ou armazenamento das amostras. Como resultado da desidratação da portlandita, percebe-se um aumento no teor total de óxido de cálcio $(\mathrm{CaO})$.

Entre 600 e $750^{\circ} \mathrm{C}$, é possível notar a continuidade no processo de decomposição do gel C-S-H, produzindo nesossilicatos na forma de belita e wollastonita $\left(\mathrm{CaSiO}_{3}\right)$. É possível observar na Figura 4.1 que o teor total de belita aumenta acentuadamente nessa faixa de temperatura. Esse aumento significativo também foi verificado em estudos recentes encontrados na literatura (SERAFINI et al., 2019a) e pode estar associado ao processo de sinterização da belita, que inicia apenas por volta de $700^{\circ} \mathrm{C}$ na produção do cimento (TAYLOR, 1997). A decomposição do carbonato de cálcio $\left(\mathrm{CaCO}_{3}\right)$ e a desidratação total da portlandita contribuem para o aumento do teor total de óxido de cálcio $(\mathrm{CaO})$ nessa faixa de temperatura.

Os resultados também indicam que o teor de ferrita $\left(\mathrm{C}_{4} \mathrm{AF}\right)$ não é modificado significativamente com o aumento da temperatura. Este resultado está diretamente associado à estabilidade física e química deste composto químico em temperaturas elevadas, o que se deve ao fato da ferrita ser formada na produção do cimento a temperaturas entre 1100 e $1250{ }^{\circ} \mathrm{C}$ e sua fusão somente se inicia por volta de $1300{ }^{\circ} \mathrm{C}$ (TAYLOR, 1997; SERAFINI et al., 2019a). O teor de óxido de magnésio $(\mathrm{MgO})$ também não é significativamente afetado pelo aumento da temperatura, o que pode estar associado à estabilidade física e química do $\mathrm{MgO}$ até sua temperatura de fusão de $\sim 2825^{\circ} \mathrm{C}$. Além disso, a decomposição de C-S-H em nesossilicato na forma de alita $\left(\mathrm{C}_{3} \mathrm{~S}\right)$ não foi verificada nas amostras avaliadas neste estudo, o que é justificado pelo fato de que o processo de sinterização da alita ocorre para temperaturas em torno de 1250 ${ }^{\circ} \mathrm{C}$ (TAYLOR, 1997). 
Os resultados obtidos para todas as temperaturas em termos de análise de DRX estão em concordância com as referências na literatura e justificam diversas alterações nas propriedades mecânicas do compósito analisado em mesoescala.

\subsection{Teor médio de fibras de aço nas amostras de CRFA}

A Figura 4.2 apresenta o percentual da contribuição das fibras de aço nos três eixos coordenados de orientação do corpo de prova, sendo o eixo $\mathrm{X}$ relativo à profundidade do cubo, o Y ao comprimento, no sentido longitudinal da viga, e o $\mathrm{Z}$ à altura (eixo vertical). Por meio do processo de determinação da reta de calibração para os três teores de fibras comprovou-se a relação linear entre a massa de fibras e a indutância equivalente, visto que o coeficiente de determinação $\mathrm{R}^{2}$ foi próximo a 1 . Analisando os dados obtidos para os cubos moldados percebese que as fibras de aço se orientaram, preferencialmente, perpendicularmente ao eixo Z, paralelas ao plano XY. Assim, é possível concluir que as fibras tenderam a se alinhar paralelamente ao maior comprimento do prisma, geometria inicial antes dos cortes em cubos.

Verificou-se que a metodologia do corte das vigas pode ser benéfica frente à moldagem direta dos cubos, uma vez que, por meio dessa técnica, pode-se reduzir o efeito parede do molde e sua influência na orientação final das fibras. Dessa forma, todos os corpos de prova apresentaram comportamento bem definido, mesmo em um molde de pequenas dimensões, apresentando orientação preferencial paralela ao eixo Y, independente da região de origem do cubo (extremidade ou centro do prisma). Isso foi observado para todos os grupos de amostras, independente da dosagem de fibras utilizada. Entretanto, verifica-se uma relação direta entre o aumento do teor de fibras de aço e a orientação preferencial paralela ao eixo Y, visto que nas amostras correspondentes à dosagem de projeto de $20 \mathrm{~kg} / \mathrm{m}^{3}$ há contribuição de $39,5 \%$ das fibras nesta condição, frente a $41,2 \%$ e $44,1 \%$ nas dosagens de $35 \mathrm{~kg} / \mathrm{m}^{3}$ e $70 \mathrm{~kg} / \mathrm{m}^{3}$, respectivamente.

A Tabela 4.2 apresenta o teor médio de fibras incorporado para cada grupo de amostras ensaiadas. Por meio de sua análise, percebe-se a importância deste método como controle de qualidade na avaliação da distribuição de fibras entre os corpos de prova produzidos de uma mesma moldagem, apresentando alta sensibilidade à variação no teor de fibras entre essas amostras. Comparando os grupos de cada temperatura-alvo dentro do mesmo teor, não há diferença estatisticamente significativa entre as amostras. Isto comprova que as amostras foram produzidas com elevado grau de homogeneidade. 
Os teores médios de fibras obtidos validam os parâmetros de dosagem de 20,35 e $70 \mathrm{~kg} / \mathrm{m}^{3}$ utilizados no processo de moldagem dos corpos de prova de CRFA. Pode-se concluir, então, que o Método Indutivo é eficaz para identificação do teor de fibras de aço nas amostras. Assim, para fins de análises neste estudo, as amostras cúbicas apresentam teores de fibras de aço comparáveis, dentro do teor de projeto analisado.

Figura 4.2 - Contribuição das fibras de aço por eixo para as dosagens: (a) $20 \mathrm{~kg} / \mathrm{m}^{3}$; (b) $35 \mathrm{~kg} / \mathrm{m}^{3}$; (c) $70 \mathrm{~kg} / \mathrm{m}^{3}$
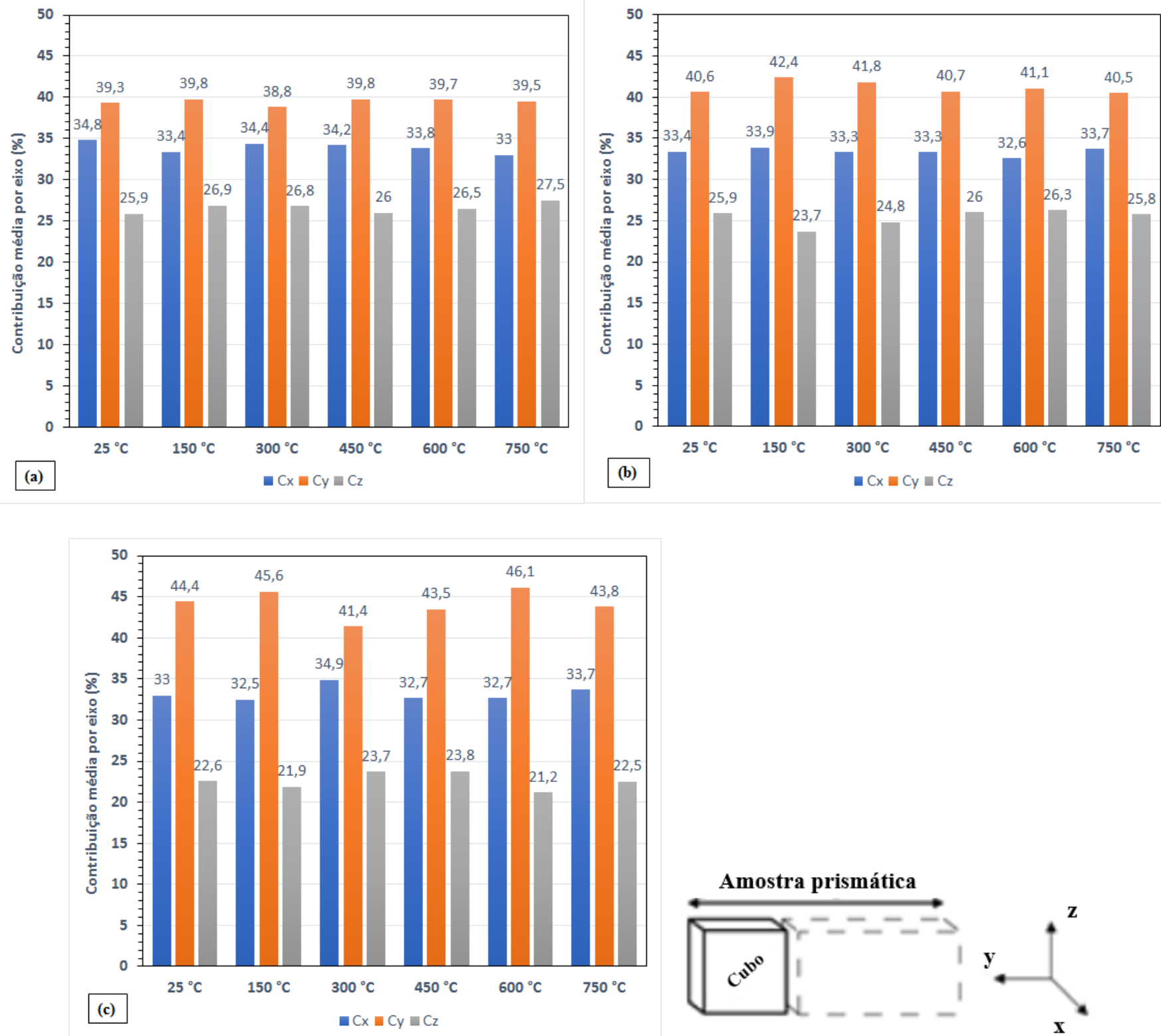

Fonte: Elaborado pelo autor 
Tabela 4.2 - Teor real médio de fibras de aço para as dosagens de projeto: 20,35 e $70 \mathrm{~kg} / \mathrm{m}^{3}$

\begin{tabular}{cccc}
\hline & \multicolumn{3}{c}{ Teor real médio de fibras de aço $\left(\mathrm{kg} / \mathrm{m}^{3}\right)$} \\
\cline { 2 - 4 } $\begin{array}{c}\text { Temperatura } \\
\left({ }^{\circ} \mathrm{C}\right)\end{array}$ & $\begin{array}{c}\text { Dosagem de projeto } \\
\text { de } 20 \mathrm{~kg} / \mathrm{m}^{3}\end{array}$ & $\begin{array}{c}\text { Dosagem de projeto } \\
\text { de } 35 \mathrm{~kg} / \mathrm{m}^{3}\end{array}$ & $\begin{array}{c}\text { Dosagem de projeto } \\
\text { de } 70 \mathrm{~kg} / \mathrm{m}^{3}\end{array}$ \\
\hline 25 & $20,3( \pm 3,2)$ & $35,7( \pm 1,8)$ & $70,7( \pm 5,9)$ \\
150 & $19,9( \pm 4,2)$ & $37,5( \pm 1,9)$ & $71,7( \pm 4,8)$ \\
300 & $20,5( \pm 4,4)$ & $36,1( \pm 3,9)$ & $68,6( \pm 5,9)$ \\
450 & $21,0( \pm 4,0)$ & $36,8( \pm 2,9)$ & $67,9( \pm 5,0)$ \\
600 & $19,8( \pm 3,2)$ & $36,3( \pm 3,1)$ & $70,4( \pm 5,5)$ \\
750 & $19,6( \pm 3,4)$ & $36,9( \pm 3,0)$ & $69,5( \pm 5,1)$ \\
\hline
\end{tabular}

\subsection{Avaliação do CRFA após exposição a elevadas temperaturas}

\subsubsection{Perda de massa, densidade e módulo de elasticidade dinâmico}

A Tabela 4.3 apresenta os resultados médios de massa, velocidade de pulso ultrassônico e módulo de elasticidade dinâmico nas temperaturas em estudo para os três teores de fibras. As Figuras 4.3 e 4.4 ilustram as reduções nos valores dessas propriedades em função do aquecimento dos corpos de prova, as quais foram utilizadas para averiguar o impacto nas propriedades elásticas dinâmicas do compósito em cada temperatura-alvo.

Após exposição a elevadas temperaturas, as reduções encontradas nos valores de massa, densidade e módulo de elasticidade dinâmico podem estar associadas com o aumento da porosidade da pasta de cimento e a formação acentuada de fissuras, visto que há intensa decomposição dos produtos de hidratação (BAŽANT; KAPLAN, 1996). Essas reduções se apresentaram próximas entre as amostras, independente do teor de fibra de aço empregado, o que indica que não há relação entre o teor de fibra adotado e as alterações nos valores dessas propriedades.

A perda de massa ocorreu com a mesma tendência para os três teores de fibras, inclusive com reduções equivalentes entre eles, como indicado na Figura 4.3. Entretanto, como indicado na Tabela 4.3, amostras com $70 \mathrm{~kg} / \mathrm{m}^{3}$ de fibras apresentaram maiores valores absolutos de massa, independente da temperatura em análise, o que deve ocorrer pelo fato de a densidade do concreto ser maior quanto maior o teor de fibras de aço. Após exposição à $750{ }^{\circ} \mathrm{C}$, as amostras apresentaram reduções próximas a $10 \%$ nos valores de massa, quando comparados à temperatura ambiente. 
Os valores obtidos de densidade do concreto à temperatura ambiente foram de (2424 \pm 30$)$, $(2432 \pm 32)$ e $(2489 \pm 22) \mathrm{kg} / \mathrm{m}^{3}$ para os teores de fibra de aço de 20,35 e $70 \mathrm{~kg} / \mathrm{m}^{3}$, respectivamente. As reduções se apresentaram equivalentes, em torno de $10 \%$ após aquecimento à $750{ }^{\circ} \mathrm{C}$, independente do teor de fibra adotado. A variação dessa propriedade com a temperatura indica relação direta com o aumento de vazios, o que está relacionada com a perda de módulo de elasticidade, visto que se trata de fração volumétrica. Além disso, os poros saturados com a exposição das amostras à umidade ambiente proporcionam um ganho de densidade e rigidez ao material. Com o aquecimento das amostras, a água é evaporada, os poros são esvaziados e a rigidez do compósito é reduzida.

O ensaio de módulo por ultrassom apresentou-se sensível às condições de integridade do concreto, principalmente quanto à detecção de existência de fissuras e localização de descontinuidades internas. Nos concretos que não foram aquecidos, o tempo de deslocamento do pulso ultrassônico entre os transdutores é curto, visto que o material se apresenta íntegro e com poucos vazios. O tempo de propagação do pulso também aumenta proporcionalmente à temperatura de exposição do concreto, pois a presença de vazios causa o retardo das ondas, em função da reduzida velocidade do som no ar. Logo, o pulso ultrassônico constitui também um método de avaliação de dano das amostras e tem relação direta com a densidade do material.

Mesmo após o resfriamento, tornou-se difícil determinar o pulso ultrassônico em amostras que foram submetidas a temperaturas a partir de $450{ }^{\circ} \mathrm{C}$ devido, principalmente, ao surgimento e propagação de fissuras de origem térmica. Em amostras que foram submetidas à $750{ }^{\circ} \mathrm{C}$ não foi possível mensurar valores confiáveis de velocidade de pulso, visto que estas se encontravam severamente fissuradas e degradadas, o que indica que suas propriedades microestruturais também estavam comprometidas. Dessa forma, em muitas amostras, a transmissão do pulso foi obstruída, de modo que este foi refletido completamente pela fissura e não foi possível medir o tempo de propagação.

O aumento do teor de fibras de aço não proporcionou alterações significativas na redução dos valores de velocidade de pulso, o que pode ser visto na Figura 4.4, que apresenta o comportamento global das amostras (para todos os teores empregados). Após exposição às temperaturas de $150,300,450$ e $600{ }^{\circ} \mathrm{C}$, a velocidade de propagação de pulso ultrassônico reduziu em torno de $10 \%, 40 \%, 60 \%$ e $80 \%$ respectivamente, enquanto o módulo de elasticidade dinâmico reduziu em torno de $20 \%, 65 \%, 85 \%$ e $95 \%$, respectivamente. 
Tabela 4.3 - Valores médios de massa e velocidade de pulso ultrassônico do CRFA para cada temperatura

\begin{tabular}{|c|c|c|c|c|c|c|c|}
\hline \multirow[b]{2}{*}{$\begin{array}{c}\text { Temperatura } \\
\left({ }^{\circ} \mathrm{C}\right)\end{array}$} & \multirow{2}{*}{$\begin{array}{c}\text { Dosagem } \\
\left(\mathrm{kg} / \mathrm{m}^{3}\right) \\
(\% \mathrm{em} \\
\text { volume })\end{array}$} & \multicolumn{3}{|c|}{ Antes da exposição à temperatura } & \multicolumn{3}{|c|}{ Após exposição à temperatura } \\
\hline & & $\begin{array}{l}\text { Massa } \\
(\mathrm{kg})\end{array}$ & $\begin{array}{c}\text { Velocidade } \\
\text { da onda } \\
(\mathrm{mm} / \mu \mathrm{s})\end{array}$ & $\begin{array}{l}\text { Módulo } \\
\text { dinâmico } \\
(\mathrm{GPa})\end{array}$ & $\begin{array}{l}\text { Massa } \\
(\mathrm{kg})\end{array}$ & $\begin{array}{c}\text { Velocidade } \\
\text { da onda } \\
(\mathrm{mm} / \mu \mathrm{s})\end{array}$ & $\begin{array}{l}\text { Módulo } \\
\text { dinâmico } \\
(\mathrm{GPa})\end{array}$ \\
\hline \multirow{6}{*}{25} & 20 & 3,73 & 4,93 & 53,04 & & & \\
\hline & $(0,26 \%)$ & $( \pm 0,04)$ & $( \pm 0,01)$ & $( \pm 0,70)$ & - & - & - \\
\hline & 35 & 3,79 & 4,97 & 54,48 & & & \\
\hline & $(0,45 \%)$ & $( \pm 0,05)$ & $( \pm 0,07)$ & $( \pm 1,43)$ & - & - & - \\
\hline & 70 & 3,87 & 4,97 & 55,41 & & & \\
\hline & $(0,90 \%)$ & $( \pm 0,02)$ & $( \pm 0,04)$ & $( \pm 0,84)$ & - & - & - \\
\hline \multirow{6}{*}{150} & 20 & 3,70 & 4,90 & 51,51 & 3,54 & 4,55 & 42,42 \\
\hline & $(0,26 \%)$ & $( \pm 0,02)$ & $( \pm 0,03)$ & $( \pm 0,65)$ & $( \pm 0,02)$ & $( \pm 0,04)$ & $( \pm 0,87)$ \\
\hline & 35 & 3,74 & 4,93 & 53,82 & 3,66 & 4,53 & 44,34 \\
\hline & $(0,45 \%)$ & $( \pm 0,04)$ & $( \pm 0,03)$ & $( \pm 0,85)$ & $( \pm 0,03)$ & $( \pm 0,02)$ & $( \pm 0,79)$ \\
\hline & 70 & 3,86 & 5,04 & 56,98 & 3,75 & 4,57 & 45,60 \\
\hline & $(0,90 \%)$ & $( \pm 0,05)$ & $( \pm 0,03)$ & $( \pm 0,92)$ & $( \pm 0,06)$ & $( \pm 0,06)$ & $( \pm 1,35)$ \\
\hline \multirow{6}{*}{300} & 20 & 3,71 & 4,92 & 52,17 & 3,50 & 3,03 & 18,64 \\
\hline & $(0,26 \%)$ & $( \pm 0,01)$ & $( \pm 0,02)$ & $( \pm 0,48)$ & $( \pm 0,01)$ & $( \pm 0,06)$ & $( \pm 0,68)$ \\
\hline & 35 & 3,73 & 4,97 & 53,99 & 3,54 & 3,09 & 19,79 \\
\hline & $(0,45 \%)$ & $( \pm 0,06)$ & $( \pm 0,03)$ & $( \pm 1,08)$ & $( \pm 0,07)$ & $( \pm 0,03)$ & $( \pm 0,74)$ \\
\hline & 70 & 3,88 & 4,98 & 55,83 & 3,67 & 3,06 & 19,97 \\
\hline & $(0,90 \%)$ & $( \pm 0,05)$ & $( \pm 0,02)$ & $( \pm 0,47)$ & $( \pm 0,06)$ & $( \pm 0,07)$ & $( \pm 0,83)$ \\
\hline \multirow{6}{*}{450} & 20 & 3,73 & 4,93 & 52,87 & 3,48 & 1,99 & 7,98 \\
\hline & $(0,26 \%)$ & $( \pm 0,03)$ & $( \pm 0,02)$ & $( \pm 0,64)$ & $( \pm 0,03)$ & $( \pm 0,01)$ & $( \pm 0,09)$ \\
\hline & 35 & 3,76 & 4,94 & $53,71( \pm$ & 3,54 & 2,10 & 9,12 \\
\hline & $(0,45 \%)$ & $( \pm 0,06)$ & $( \pm 0,04)$ & $1,16)$ & $( \pm 0,06)$ & $( \pm 0,06)$ & $( \pm 0,54)$ \\
\hline & 70 & 3,87 & 4,93 & $54,41( \pm$ & 3,64 & 2,12 & 9,44 \\
\hline & $(0,90 \%)$ & $( \pm 0,04)$ & $( \pm 0,03)$ & $1,40)$ & $( \pm 0,05)$ & $( \pm 0,05)$ & $( \pm 0,32)$ \\
\hline \multirow{6}{*}{600} & 20 & 3,73 & 4,91 & 52,28 & 3,42 & 1,15 & 2,63 \\
\hline & $(0,26 \%)$ & $( \pm 0,04)$ & $( \pm 0,01)$ & $( \pm 0,69)$ & $( \pm 0,02)$ & $( \pm 0,03)$ & $( \pm 0,14)$ \\
\hline & 35 & 3,73 & 4,99 & 55,28 & 3,48 & 1,15 & 2,73 \\
\hline & $(0,45 \%)$ & $( \pm 0,05)$ & $( \pm 0,05)$ & $( \pm 1,41)$ & $( \pm 0,07)$ & $( \pm 0,03)$ & $( \pm 0,11)$ \\
\hline & 70 & 3,85 & 4,95 & 54,63 & 3,54 & 1,04 & 2,21 \\
\hline & $(0,90 \%)$ & $( \pm 0,03)$ & $( \pm 0,02)$ & $( \pm 0,92)$ & $( \pm 0,03)$ & $( \pm 0,02)$ & $( \pm 0,08)$ \\
\hline \multirow{6}{*}{750} & 20 & 3,74 & 4,83 & 51,21 & 3,39 & & \\
\hline & $(0,26 \%)$ & $( \pm 0,02)$ & $( \pm 0,04)$ & $( \pm 0,99)$ & $( \pm 0,02)$ & - & - \\
\hline & 35 & 3,73 & 4,92 & 53,02 & 3,47 & & \\
\hline & $(0,45 \%)$ & $( \pm 0,05)$ & $( \pm 0,01)$ & $( \pm 0,40)$ & $( \pm 0,05)$ & - & - \\
\hline & 70 & 3,86 & 4,95 & 55,01 & 3,51 & & \\
\hline & $(0,90 \%)$ & $( \pm 0,03)$ & $( \pm 0,03)$ & $( \pm 0,79)$ & $( \pm 0,01)$ & - & - \\
\hline
\end{tabular}


Figura 4.3 - Perda de massa em função da temperatura para as amostras de CRFA

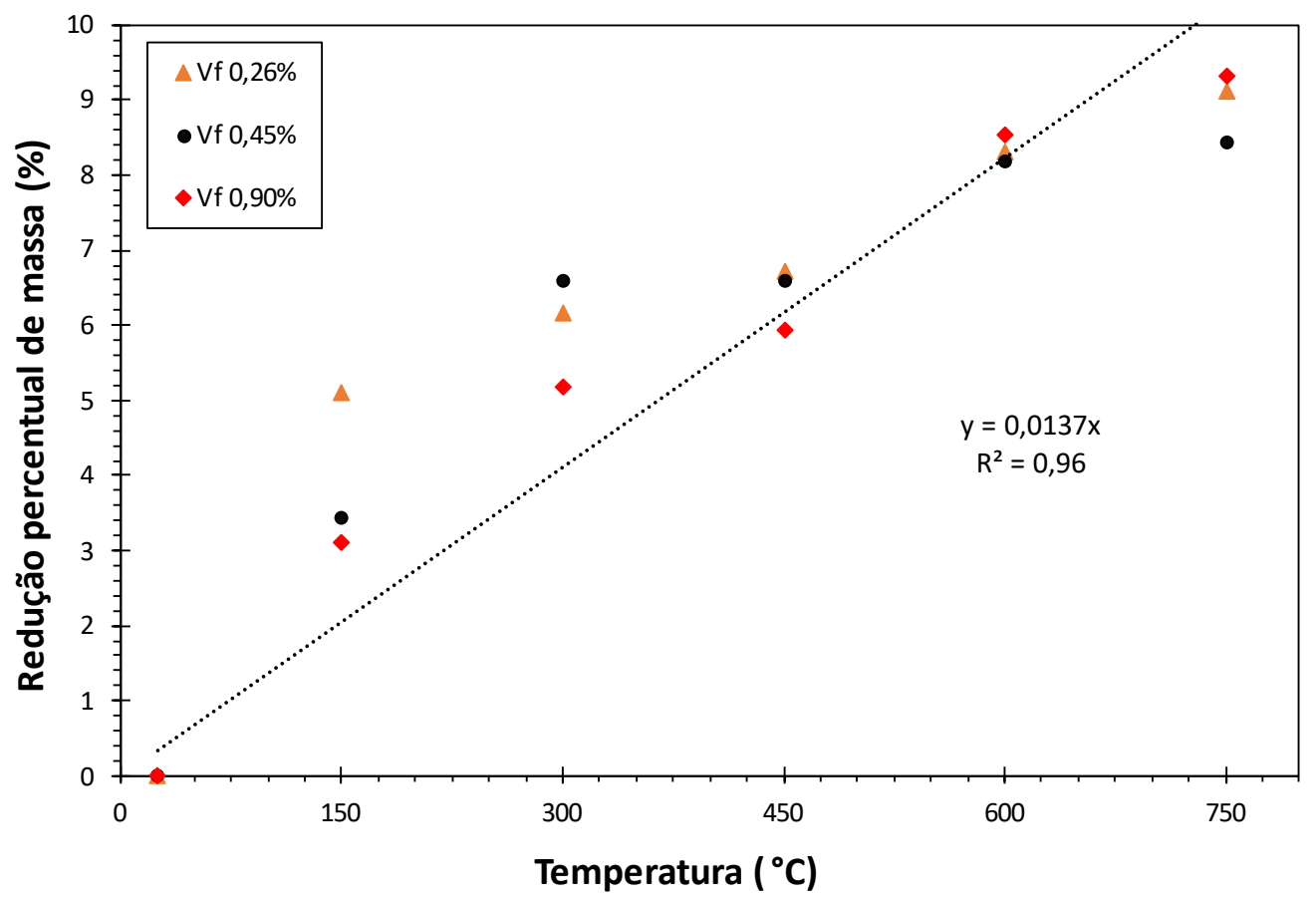

Fonte: Elaborado pelo autor

Figura 4.4 - Variação do módulo de elasticidade dinâmico e velocidade do pulso ultrassônico em função da temperatura (comportamento para todos os teores de fibra de aço)

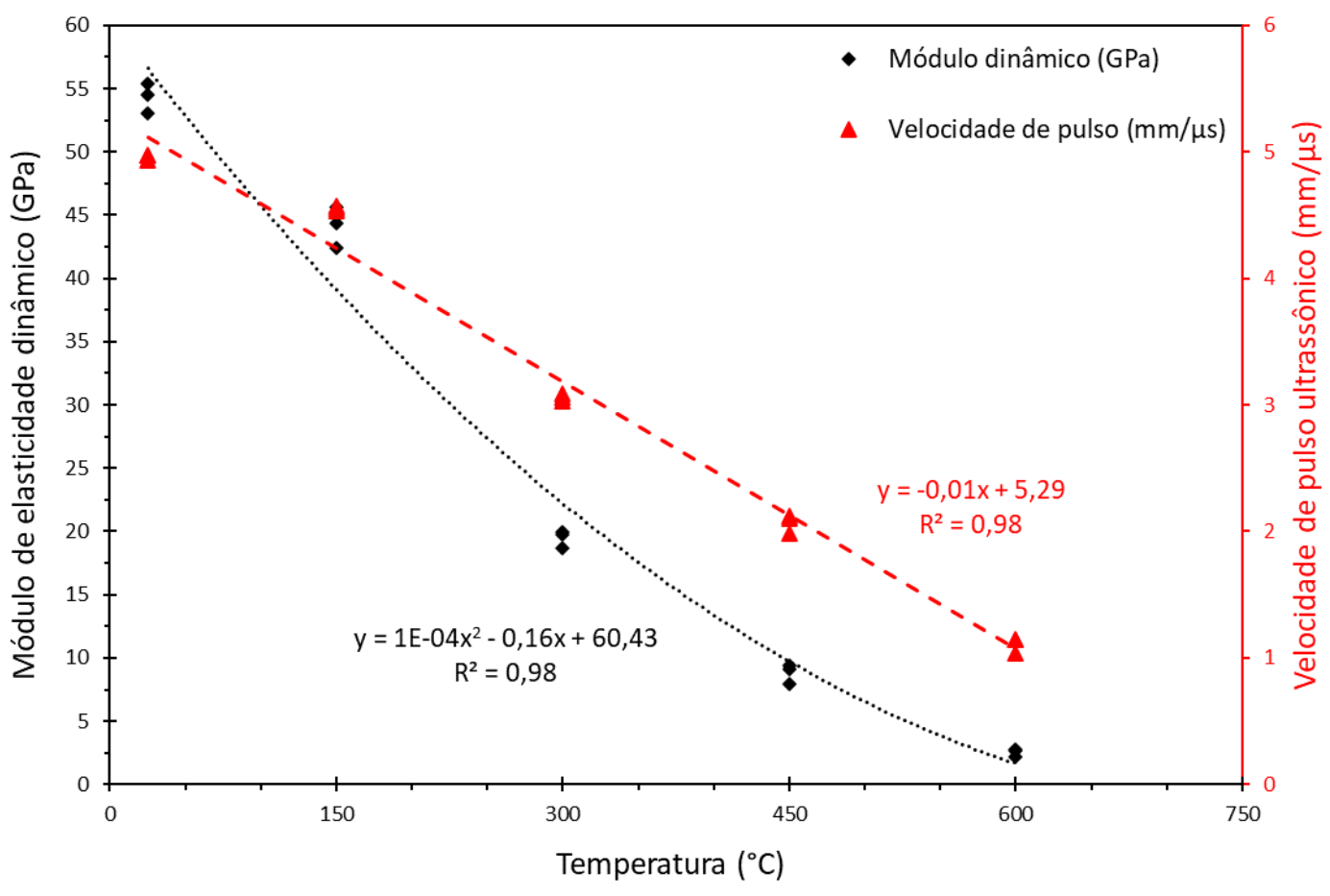

Fonte: Elaborado pelo autor 


\subsubsection{Resistência à compressão e módulo de elasticidade estático}

A Figura 4.5 apresenta as curvas tensão-deformação para cada grupo de amostras de CRFA, discriminadas por teor de fibras e temperatura alvo. O efeito em termos de módulo de elasticidade pode ser observado, de forma qualitativa, pela variação da inclinação das curvas tensão-deformação do compósito. Os resultados médios de resistência à compressão e módulo de elasticidade estático nas temperaturas em estudo para os três teores de fibras são apresentados na Tabela 4.4, complementados pela Figura 4.6, pela qual é possível observar as reduções nos valores dessas propriedades em função do aquecimento dos corpos de prova, além da comparação com os coeficientes de degradação mecânica preconizados pelo Eurocode (2004).

Tabela 4.4 - Valores médios de resistência à compressão e módulo de elasticidade estático por temperatura

\begin{tabular}{|c|c|c|c|}
\hline $\begin{array}{l}\text { Temperatura } \\
\left({ }^{\circ} \mathrm{C}\right)\end{array}$ & $\begin{array}{c}\text { Dosagem }\left(\mathrm{kg} / \mathrm{m}^{3}\right) \\
(\% \text { em volume })\end{array}$ & fcm $(\mathrm{MPa})$ & $\mathrm{Ec}(\mathrm{GPa})$ \\
\hline \multirow{3}{*}{25} & $20(0,26 \%)$ & $84,80( \pm 2,06)$ & $34,83( \pm 0,68)$ \\
\hline & $35(0,45 \%)$ & $91,81( \pm 2,05)$ & $35,74( \pm 0,82)$ \\
\hline & $70(0,90 \%)$ & $90,77( \pm 1,14)$ & $36,92( \pm 0,64)$ \\
\hline \multirow{3}{*}{150} & $20(0,26 \%)$ & $72,99( \pm 2,06)$ & $25,71( \pm 0,52)$ \\
\hline & $35(0,45 \%)$ & $78,20( \pm 2,08)$ & $27,14( \pm 0,26)$ \\
\hline & $70(0,90 \%)$ & $84,67( \pm 1,97)$ & $28,86( \pm 0,36)$ \\
\hline \multirow{3}{*}{300} & $20(0,26 \%)$ & $44,17( \pm 1,29)$ & $9,57( \pm 0,42)$ \\
\hline & $35(0,45 \%)$ & $62,49( \pm 1,68)$ & $10,91( \pm 0,34)$ \\
\hline & $70(0,90 \%)$ & $66,92( \pm 1,76)$ & $11,81( \pm 0,37)$ \\
\hline \multirow{3}{*}{450} & $20(0,26 \%)$ & $34,96( \pm 0,85)$ & $3,62( \pm 0,21)$ \\
\hline & $35(0,45 \%)$ & $37,54( \pm 1,04)$ & $4,37( \pm 0,22)$ \\
\hline & $70(0,90 \%)$ & $46,79( \pm 1,33)$ & $4,46( \pm 0,18)$ \\
\hline \multirow{3}{*}{600} & $20(0,26 \%)$ & $13,13( \pm 0,35)$ & $1,05( \pm 0,08)$ \\
\hline & $35(0,45 \%)$ & $19,79( \pm 0,72)$ & $1,22( \pm 0,06)$ \\
\hline & $70(0,90 \%)$ & $16,95( \pm 0,45)$ & $1,41( \pm 0,09)$ \\
\hline \multirow{3}{*}{$750{ }^{\circ} \mathrm{C}$} & $20(0,26 \%)$ & $1,66( \pm 0,03)$ & $0,08( \pm 0,01)$ \\
\hline & $35(0,45 \%)$ & $2,20( \pm 0,07)$ & $0,28( \pm 0,03)$ \\
\hline & $70(0,90 \%)$ & $1,98( \pm 0,08)$ & $0,37( \pm 0,02)$ \\
\hline
\end{tabular}


Figura 4.5 - Curvas tensão-deformação em função da temperatura para os teores de fibras de aço, em volume, de: (a) $0,26 \%$; (b) $0,45 \%$; (c) $0,90 \%$
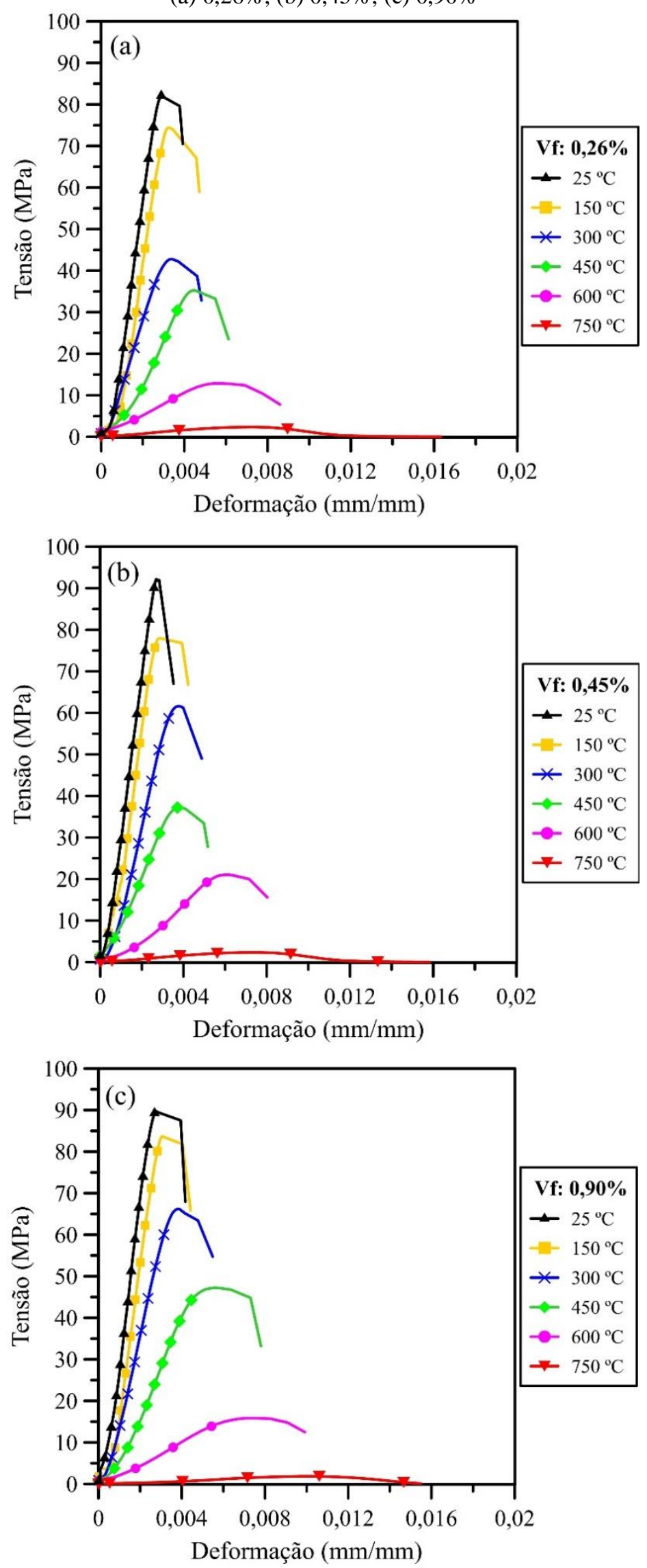

Fonte: Elaborado pelo autor 
Figura 4.6 - Redução da resistência à compressão e módulo de elasticidade em função da temperatura para os teores de fibras de aço, em volume, de $0,26 \%, 0,45 \%$ e $0,90 \%$

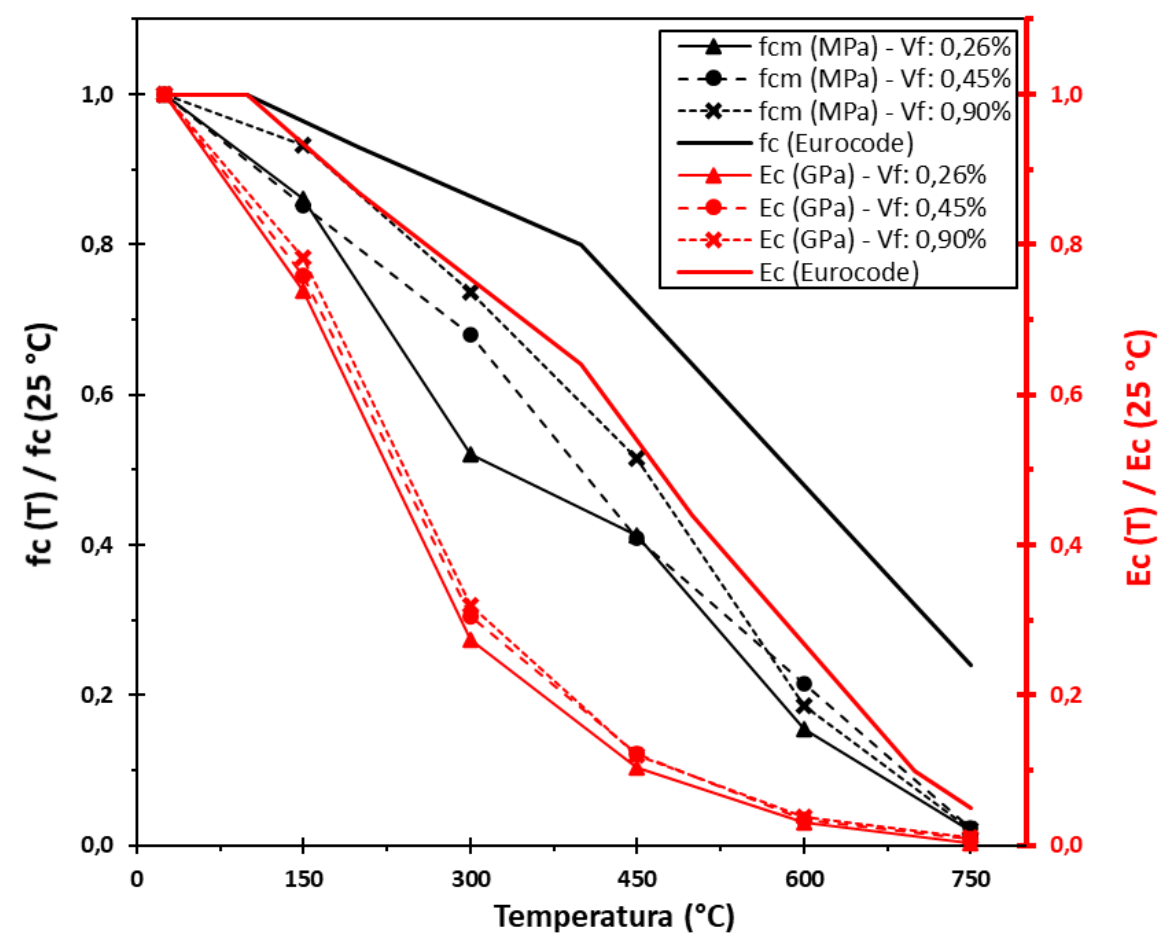

Fonte: Elaborado pelo autor

O aumento do teor de fibras de aço não implicou ganho significativo de resistência à compressão na temperatura ambiente, apesar de que, em termos de resistência residual (póstemperatura), existiu contribuição até $450{ }^{\circ} \mathrm{C}$. Até esta temperatura, observou-se que as amostras com maior teor apresentaram reduções mais brandas $\left(\sim 0,10 \mathrm{MPa} /{ }^{\circ} \mathrm{C}\right)$ em relação aos grupos com teores inferiores $\left(\sim 0,15\right.$ a $\left.0,20 \mathrm{MPa} /{ }^{\circ} \mathrm{C}\right)$. Assim, as reduções apresentadas nas amostras com $70 \mathrm{~kg} / \mathrm{m}^{3}$ de fibras de aço até $450{ }^{\circ} \mathrm{C}$ foram cerca de $10 \%$ menores que as apresentadas com as duas dosagens inferiores. Esse resultado pode estar relacionado com a atuação das fibras, que interrompem a rápida propagação de microfissuras na matriz do concreto quanto submetido a elevadas temperaturas. As fibras atuam no controle da abertura dessas fissuras, impedindo que o aumento da porosidade do concreto - e a consequente perda de resistência à compressão - ocorra de forma brusca. Esse efeito favorável também foi constatado no estudo de Chan et al. (2000) e Felicetti et al. (2000).

Entretanto, após ter sua capacidade mecânica reduzida a partir de $450{ }^{\circ} \mathrm{C}$, as fibras deixam de proporcionar esse benefício, o que é notado na Figura 4.6, com a intensificação na redução da resistência à compressão no concreto com alto teor de fibras. Após aquecimento a $600{ }^{\circ} \mathrm{C}$ as amostras preservaram cerca de $20 \%$ da sua resistência inicial, independente do teor de fibras 
empregado, de forma que em $750{ }^{\circ} \mathrm{C}$ não apresentaram capacidade mecânica considerável. A redução significativa a partir de $300{ }^{\circ} \mathrm{C}$ também pode estar relacionada com a decomposição dos produtos de hidratação presentes na pasta e com a incompatibilidade entre as deformações térmicas do agregado (que expande) e da pasta (que retrai), induzindo fissuras radiais e tangenciais na zona de transição.

As reduções nos valores de módulo de elasticidade ocorreram de forma mais acentuada em relação à resistência à compressão e independeram do teor de fibra de aço empregado, visto que se apresentaram próximas entre as amostras com teores distintos. Isto sugere que esta propriedade tem relação direta com a redução do volume de sólidos na pasta de cimento e dos agregados, e que pequenas diferenças nesses valores são intrínsecas a uma metodologia experimental. Yermak et al. (2017) também observaram que a adição de fibras de aço não proporciona contribuição significativa na redução do módulo de elasticidade com o aumento da temperatura.

A rigidez do compósito foi afetada de forma direta pelo aumento da porosidade, relacionado com o processo de decomposição dos produtos de hidratação presentes na matriz (especialmente portlandita e C-S-H), além da propagação de fissuras de origem térmica e a degradação das microfibras sintéticas. Esses fatores justificam a redução observada nas propriedades elásticas do compósito com a elevação da temperatura, de forma que após exposição a $450{ }^{\circ} \mathrm{C}$, as amostras conservavam apenas $15 \%$ do valor obtido na temperatura ambiente, independente do teor de fibra de aço empregado.

Os valores de redução apresentados na Figura 4.6 são menores que os apresentados no Eurocode (2004), o que pode ser atribuído ao regime de aquecimento adotado e ao aumento da porosidade proporcionado pela degradação das microfibras sintéticas. Ao comparar esses valores com resultados da literatura para estudos realizados em classes de concreto e teores de fibras similares (CHAN et al., 2000; FELICETTI et al., 2000; PHAN e CARINO, 2002; YERMAK et al., 2017; POON et al., 2004; TAI et al., 2011; CHEN et al., 2004; ZHENG et al., 2012), algumas diferenças encontradas podem estar relacionadas com a composição da matriz - especialmente pela utilização de finos e agregados silicosos - além da taxa de aquecimento distinta entre os estudos. Entretanto, ao comparar os resultados com um concreto com mesma composição e tipo de fibra (SERAFINI et al., 2019a; SERAFINI et al., 2020b), os valores se apresentam próximos. 


\subsubsection{Resistência à tração e resistência à tração pós-fissuração}

A Figura 4.7 apresenta as curvas de resistência à tração média por abertura de fissura (COD) obtidas por meio do ensaio DEWS nas temperaturas específicas de 25, 150, 300, 450, 600 e $750{ }^{\circ} \mathrm{C}$ para os três teores de fibras de aço em análise $(0,26 \%, 0,45 \%$ e $0,90 \%)$, o que também abrange os valores de resistência à tração pós-fissuração do compósito. Os valores médios de resistência à tração da matriz $\left(\mathrm{f}_{\mathrm{tc}}\right)$ e de resistências residuais associadas ao ELS $\left(\mathrm{f}_{\mathrm{t} 0,25)}\right.$ e ELU ( $\left.f_{t 1,25}\right)$ estão dispostos na Tabela 4.5, onde os valores de desvio padrão estão representados entre parênteses. As curvas individuais experimentais obtidas por meio do ensaio DEWS estão apresentadas no Apêndice A deste documento, enquanto o estudo da quantidade de amostras necessárias em função do erro admissível é apresentado no Apêndice B.

Por meio da Figura 4.7 é possível analisar a dinâmica de variação do comportamento das amostras em função da temperatura, cuja ação significativa nas propriedades de tração é evidenciada a partir de $300{ }^{\circ} \mathrm{C}$. Nota-se essa influência pelo decaimento das curvas, que representa a redução da capacidade resistente do compósito em níveis de resistência à tração da matriz e resistências residuais associadas ao ELS e ao ELU.

\begin{tabular}{|c|c|c|c|c|}
\hline $\begin{array}{c}\text { Temperatura } \\
\left({ }^{\circ} \mathrm{C}\right)\end{array}$ & $\begin{array}{c}\text { Dosagem }\left(\mathrm{kg} / \mathrm{m}^{3}\right) \\
(\% \text { em volume })\end{array}$ & $\mathrm{ftc}(\mathrm{MPa})$ & $\mathrm{ft} 0,25(\mathrm{MPa})$ & $\mathrm{ft} 1,25(\mathrm{MPa})$ \\
\hline \multirow{3}{*}{25} & $20(0,26 \%)$ & $3,13( \pm 0,77)$ & $1,20( \pm 0,90)$ & $0,44( \pm 0,38)$ \\
\hline & $35(0,45 \%)$ & $3,88( \pm 0,72)$ & $2,02( \pm 0,35)$ & $1,02( \pm 0,23)$ \\
\hline & $70(0,90 \%)$ & $3,91( \pm 0,72)$ & $4,45( \pm 0,99)$ & $2,66( \pm 0,74)$ \\
\hline \multirow{3}{*}{150} & $20(0,26 \%)$ & $3,57( \pm 0,38)$ & $1,55( \pm 0,78)$ & $0,58( \pm 0,34)$ \\
\hline & $35(0,45 \%)$ & $3,51( \pm 0,84)$ & $2,15( \pm 0,78)$ & $1,26( \pm 0,26)$ \\
\hline & $70(0,90 \%)$ & $3,72( \pm 0,68)$ & $4,05( \pm 0,68)$ & $3,20( \pm 1,18)$ \\
\hline \multirow{3}{*}{300} & $20(0,26 \%)$ & $1,85( \pm 0,31)$ & $0,80( \pm 0,21)$ & $0,58( \pm 0,26)$ \\
\hline & $35(0,45 \%)$ & $2,30( \pm 0,44)$ & $1,57( \pm 0,49)$ & $1,17( \pm 0,48)$ \\
\hline & $70(0,90 \%)$ & $2,65( \pm 0,36)$ & $2,67( \pm 0,49)$ & $2,58( \pm 0,88)$ \\
\hline \multirow{3}{*}{450} & $20(0,26 \%)$ & $0,89( \pm 0,27)$ & $0,50( \pm 0,19)$ & $0,35( \pm 0,17)$ \\
\hline & $35(0,45 \%)$ & $1,20( \pm 0,19)$ & $0,84( \pm 0,16)$ & $0,64( \pm 0,17)$ \\
\hline & $70(0,90 \%)$ & $1,68( \pm 0,29)$ & $1,55( \pm 0,35)$ & $1,54( \pm 0,41)$ \\
\hline \multirow{3}{*}{600} & $20(0,26 \%)$ & $0,42( \pm 0,13)$ & $0,28( \pm 0,06)$ & $0,13( \pm 0,03)$ \\
\hline & $35(0,45 \%)$ & $0,54( \pm 0,17)$ & $0,42( \pm 0,14)$ & $0,33( \pm 0,11)$ \\
\hline & $70(0,90 \%)$ & $0,88( \pm 0,17)$ & $0,80( \pm 0,17)$ & $0,70( \pm 0,14)$ \\
\hline \multirow{3}{*}{750} & $20(0,26 \%)$ & $0,10( \pm 0,02)$ & $0,06( \pm 0,01)$ & $0,01( \pm 0,01)$ \\
\hline & $35(0,45 \%)$ & $0,14( \pm 0,05)$ & $0,10( \pm 0,03)$ & $0,01( \pm 0,01)$ \\
\hline & $70(0,90 \%)$ & $0,22( \pm 0,07)$ & $0,14( \pm 0,04)$ & $0,01( \pm 0,01)$ \\
\hline
\end{tabular}


Figura 4.7 - Curvas médias de resistência à tração por abertura de fissura (COD) do CRFA nas temperaturas em estudo para os teores de fibras de aço em volume: (a) $0,26 \%$; (b) $0,45 \%$; (c) $0,90 \%$
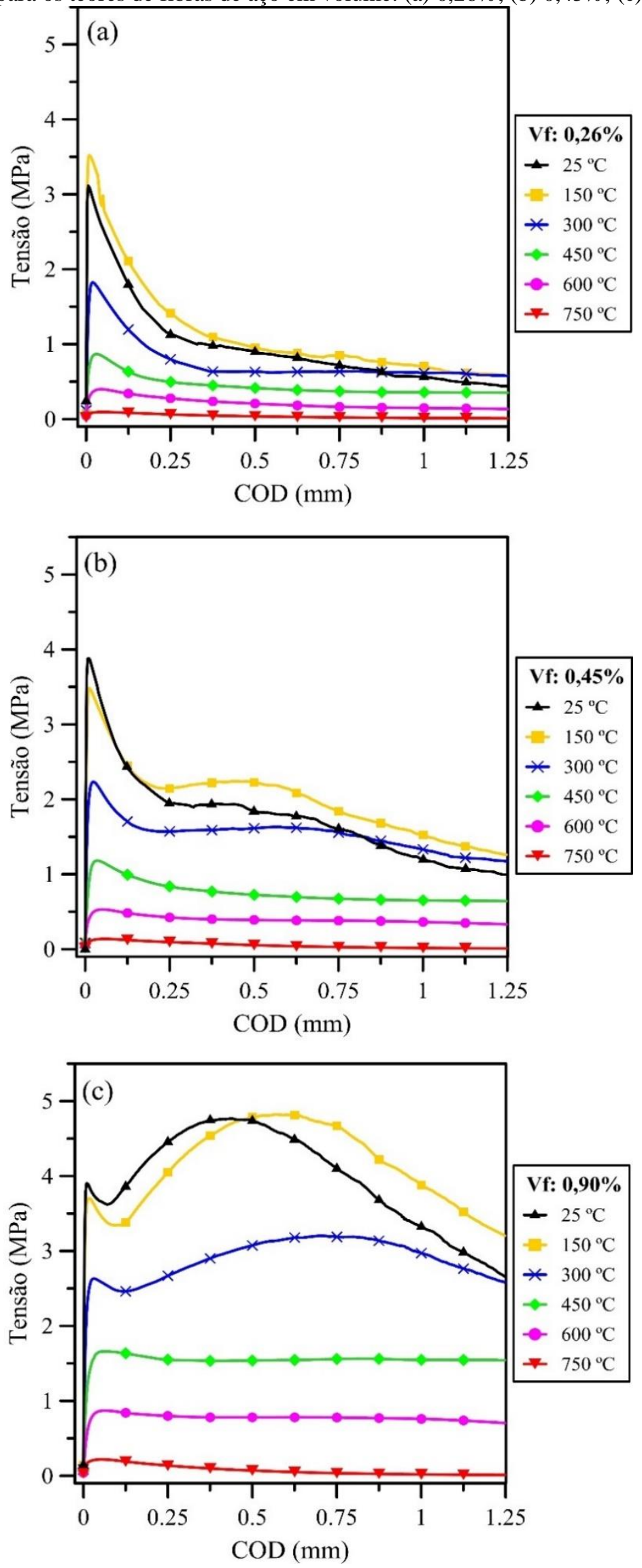

Fonte: Elaborado pelo autor 
Constatou-se que a resposta elástica inicial e os valores de resistência à tração da matriz $\left(\mathrm{f}_{\mathrm{tc}}\right)$ não são afetados de forma significativa até $150{ }^{\circ} \mathrm{C}$, independente do teor de fibra de aço empregado. A partir de $300{ }^{\circ} \mathrm{C}$ houve redução significativa nessa propriedade, devido à degradação na zona de transição interfacial e na microestrutura da pasta de cimento, associado à decomposição dos produtos de hidratação e mudanças na distribuição dos poros. Este comportamento tornou-se ainda mais evidente em temperaturas acima de $573{ }^{\circ} \mathrm{C}$, referente ao processo de transição cristalina do $\alpha$-quartzo (trigonal) para $\beta$-quartzo (hexagonal) (MA et al., 2015). Essa transformação está associada com eventos de expansão-retração, que podem gerar microfissuras na matriz cimentícia e no próprio agregado, o que pode afetar o comportamento ao arrancamento das fibras. Ressalta-se ainda que a presença de entalhes na amostra pode ter favorecido o surgimento de fissuras na região, por ser um ponto de concentração de tensões provenientes de cargas térmicas durante o aquecimento.

$\mathrm{O}$ aumento do teor de fibra não contribuiu de forma significativa para o aumento de $\mathrm{f}_{\mathrm{ct}}$ na temperatura ambiente, visto que é uma propriedade governada pela matriz cimentícia. Entretanto, observou-se para o teor de $70 \mathrm{~kg} / \mathrm{m}^{3}$ um efeito positivo ao reduzir a taxa de degradação de $\mathrm{f}_{\mathrm{ct}}$, de modo que após exposição a $450{ }^{\circ} \mathrm{C}$ e $600{ }^{\circ} \mathrm{C}$, as amostras conservavam, respectivamente, cerca de $45 \%$ e $25 \%$ da resistência inicial, enquanto os demais teores conservaram apenas $30 \%$ e $15 \%$ do valor obtido na temperatura ambiente. O valor obtido após exposição a $750{ }^{\circ} \mathrm{C}$ correspondeu a cerca de $5 \%$ do valor obtido na temperatura ambiente, independente do teor de fibra empregado, o que pode estar relacionado com a excessiva degradação da matriz e da zona de interface fibra-pasta (SERAFINI et al., 2021).

A análise estatística aponta que os valores de resistência à tração pós-fissuração associados ao ELS e ELU não são significativamente afetados até $300^{\circ} \mathrm{C}$, visto que até esta temperatura as alterações microestruturais e os efeitos de oxidação nas propriedades mecânicas de fibras de aço com extremidades em ganchos são mínimos (SERAFINI et al., 2020a). Atrelado a este mecanismo, diversos autores (ABDALLAH et al., 2017; RUANO et al., 2018; SERAFINI et al., 2021) apontam que não há influência significativa da temperatura sobre o comportamento de arrancamento das fibras de aço até $\sim 400{ }^{\circ} \mathrm{C}$. Logo, embora a matriz cimentícia esteja deteriorando, a interface fibra-matriz é pouco afetada ou até mesmo catalisada, possivelmente em função da presença de sílica $\left(\mathrm{SiO}_{2}\right)$ e portlandita $\left(\mathrm{Ca}(\mathrm{OH})_{2}\right)$ na zona de interface, o que pode explicar a redução da resistência à tração da matriz e o aumento da resistência pós-fissuração até $450{ }^{\circ} \mathrm{C}$. Presume-se que a formação de C-S-H, favorecida pela condição de autoclave gerada pela temperatura e pressão interna, reduziu a porosidade de região entre a fibra e a matriz, o que 
forneceu aderência para as fibras e, consequentemente, aumentou sua capacidade resistente nesta faixa de temperatura.

Após aquecimento a $600{ }^{\circ} \mathrm{C}$, as amostras conservavam apenas $20 \%$ e $30 \%$ das resistências associadas ao ELS e ao ELU respectivamente, independente do teor de fibra. Os valores obtidos após exposição a $750{ }^{\circ} \mathrm{C}$ corresponderam a menos de $5 \%$ dos valores obtidos na temperatura ambiente, o que em termos práticos significa que não há capacidade resistente do material nessa faixa de temperatura. As reduções gradativas observadas estão relacionadas com as mudanças físico-químicas e microestruturais na matriz, além da degradação das fibras, que perdem gradativamente sua capacidade de reforço, tornando-se friáveis e facilmente danificadas.

Por meio da Figura 4.8 é possível observar que os valores de resistência à tração da matriz e pós-fissuração associado ao ELS reduzem linearmente com o aumento da temperatura. Os valores associados ao ELU não aparentam seguir uma correlação linear única em função da temperatura, embora a partir de $300{ }^{\circ} \mathrm{C}$ apresente tendência de redução gradativa. Logo, podese afirmar que até $300^{\circ} \mathrm{C}$ a perda de comportamento mecânico no ELU é mínima e, acima desta temperatura, nota-se uma perda linear de resistência com o aumento da temperatura.

As fibras de aço perdem, progressivamente, seu potencial de encruamento com a exposição a elevadas temperaturas, ao passo que recristalizam, seus grãos aumentam de tamanho e a resistência - antes elevada pela estricção progressiva devido ao encruamento - é consideravelmente reduzida (SERAFINI et al., 2018). Há ainda mudanças em termos de diâmetro externo total e massa das fibras devido aos processos de oxidação (Figura 4.9b) e corrosão, que iniciam em $500{ }^{\circ} \mathrm{C}$ e $700{ }^{\circ} \mathrm{C}$ respectivamente, e afetam as propriedades mecânicas do compósito (SERAFINI et al., 2020a). Somado a isto, após exposição a temperaturas elevadas, o concreto perde boa parte da estrutura cristalina construída a partir da hidratação, e se apresenta bastante degradado, repleto de fissuras (Figura 4.9a).

No entanto, o aumento do teor de fibra exerceu influência positiva na capacidade resistente do compósito no trecho pós-fissuração, independente da temperatura analisada, de forma que mesmo após exposição das amostras a elevadas temperaturas, ainda houve contribuição residual no ELU, principalmente para o teor de $70 \mathrm{~kg} / \mathrm{m}^{3}$. As resistências à tração pós-fissuração são governadas pela interação fibra-pasta e, por isso, a resposta residual se apresentou de maneira distinta em função do teor de fibra empregado. Entre as amostras com baixo e alto teor neste estudo, há uma quantidade distinta de fibras com propriedades de interação fibra-matriz comparáveis, o que afeta de forma significativa o comportamento pós-fissuração do material. 
Figura 4.8 - Correlação entre as resistências médias do compósito e a temperatura: (a) resistência à tração da matriz; (b) resistência residual em $0,25 \mathrm{~mm}$; (c) resistência residual em 1,25 mm
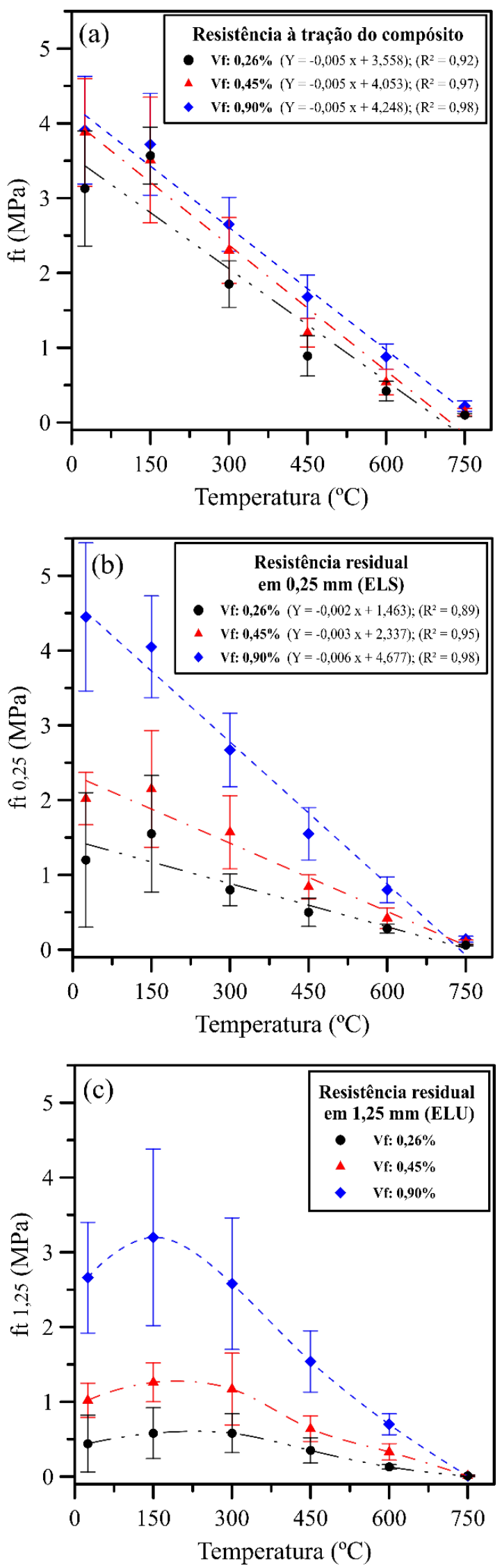

Fonte: Elaborado pelo autor 
Não foi verificada influência do teor de fibras de aço nas reduções das resistências residuais, de modo que se apresentaram próximas à medida que a temperatura aumentava. Verifica-se também, por meio da Figura 4.8, que as correlações entre os valores de resistência e as temperaturas se tornam mais bem definidas conforme o teor de fibra aumenta.

Figura 4.9 - (a) Concreto fissurado após exposição à $750{ }^{\circ} \mathrm{C}$; (b) Fibras oxidadas na lateral do corpo de prova
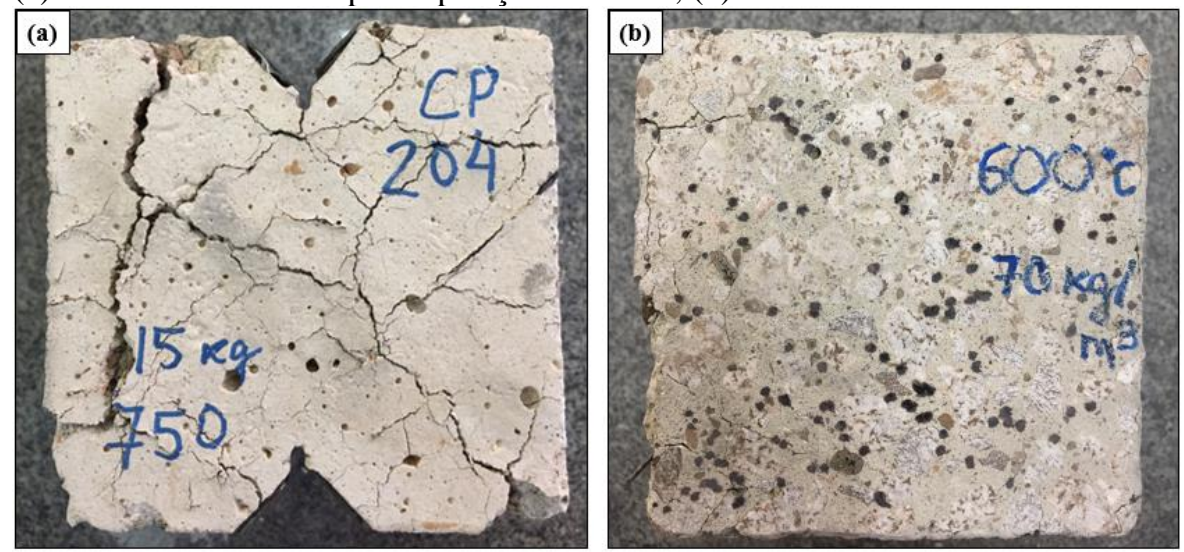

Fonte: Acervo do autor

As tensões de tração referentes à ruptura da matriz e ao comportamento pós-fissuração foram afetadas negativamente pela temperatura, seguindo regressões lineares com diferentes taxas de degradação de acordo com a propriedade analisada. Isso também implica em um aumento significativo em termos de ductilidade até $450{ }^{\circ} \mathrm{C}$, como apresentado na Figura 4.10, associado à aproximação do comportamento do material ao de um elastoplástico ideal. Entretanto, mesmo com o ganho de ductilidade, vale ressaltar que o aumento da temperatura influencia negativamente a capacidade resistente do compósito, o que afeta diretamente as condições de segurança da estrutura.

Figura 4.10 - Efeito da temperatura nos parâmetros de ductilidade do CRFA: (a) ELS; (b) ELU
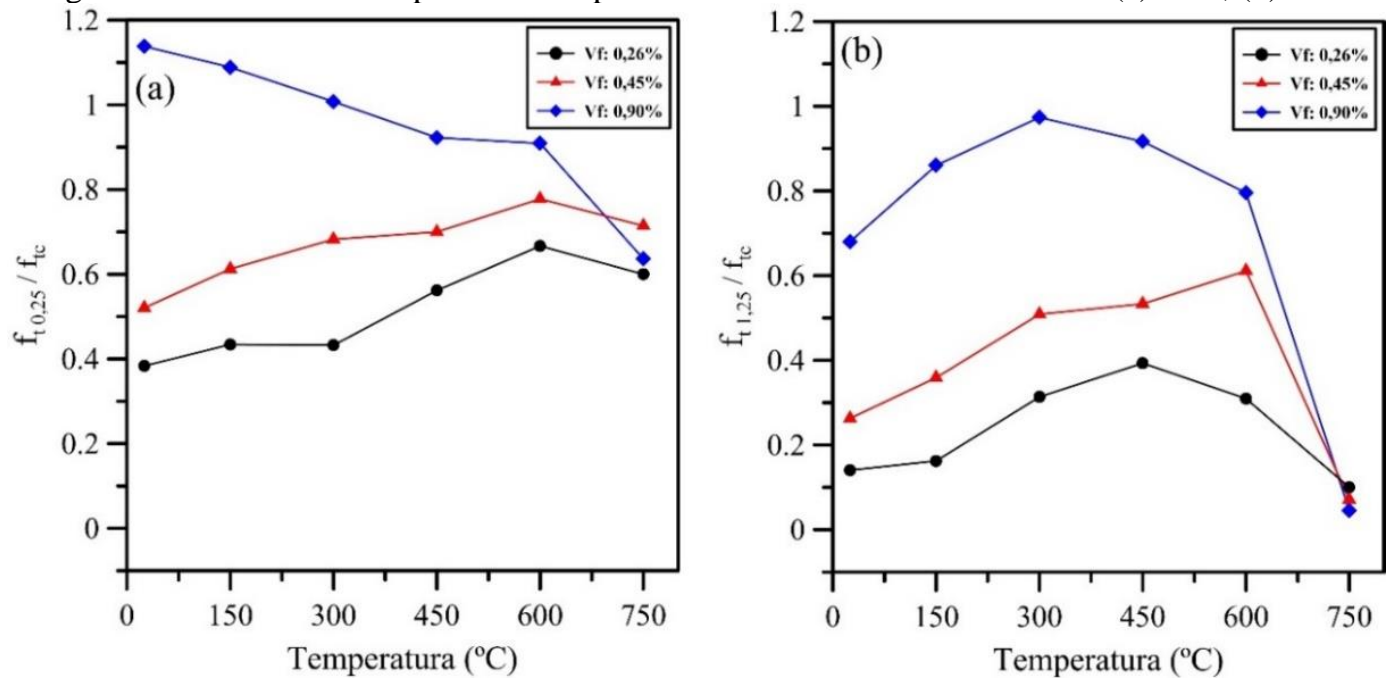

Fonte: Elaborado pelo autor 
A comparação com os resultados encontrados na literatura (CHEN \& LIU, 2004; SUHAENDI \& HORIGUCHI, 2006; YERMAK et al., 2017) torna-se limitada em função das diferenças na composição da matriz cimentícia e na taxa de aquecimento entre os estudos, além da influência da rigidez dos distintos equipamentos utilizados. Além disso, vale ressaltar que alterações em termos de métodos de avaliação da resistência à tração podem gerar respostas distintas, visto que cada ensaio tem uma resposta típica. Sabendo destas limitações, os resultados avaliados em termos de tensão apresentaram coerência quando comparados com um concreto de mesma composição e tipologia de fibra, embora empregando corpos de prova de tamanho distinto (AGRA et al., 2019; SERAFINI et al., 2020b).

Durante a execução do ensaio DEWS não houve esmagamento ou qualquer dano proveniente da interação entre os roletes e os corpos de prova, além de que a abertura da fissura ocorreu de forma similar nas faces opostas da amostra, o que indica que este ensaio constitui uma metodologia tecnicamente viável de avaliação da resistência à tração residual do CRFA após exposição a elevadas temperaturas. Assim, os resultados obtidos por meio do ensaio DEWS são representativos da resposta do material, diferentemente do que pode ocorrer com o emprego de outras técnicas, com o possível comprometimento da qualidade dos resultados obtidos. A Figura 4.11 apresenta as condições de integridade das amostras ao serem ensaiadas por este método. Em todos os casos, o modo de falha predominante consistiu em uma única fissura vertical, devido principalmente à utilização do entalhe no corpo de prova.

Figura 4.11 - Ensaio DEWS e condições de integridade das amostras à (a) temperatura ambiente e após
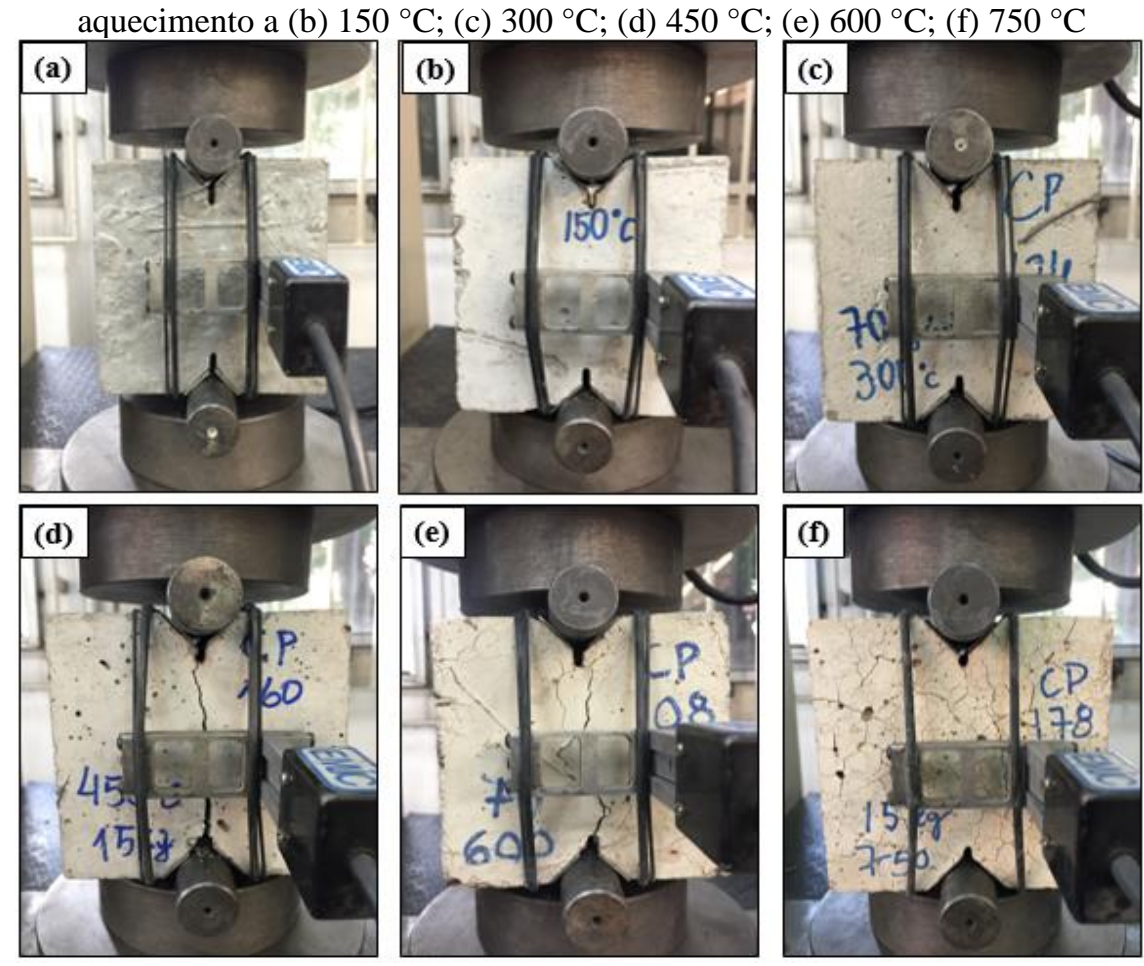


\subsubsection{Coeficientes de degradação mecânica}

A Figura 4.12 apresenta os coeficientes de degradação mecânica obtidos para este estudo em comparação com os padrões apresentados nas diretrizes europeias para projeto e construção de estruturas de CRF (CNR-DT 204, 2007; EN 1992-1-2, 2004). Estes coeficientes podem ser utilizados como fator de redução na capacidade resistente das camadas de CRFA para a avaliação de estruturas pós-incêndio. Os resultados são observados em termos de resistência à tração do compósito (Figura 4.12a) ou em termos de resistência à tração pós-fissuração associada ao ELU (Figura 4.12b). Na Figura 4.12b, a linha contínua representa a linha limite de segurança, demarcando a zona segura, enquanto a linha tracejada representa os resultados experimentais, ambos de acordo com a CNR DT 204 (2007). Assim, os resultados obtidos neste estudo, independente do teor de fibra empregado, estão a favor da segurança em relação às normativas.

Por meio da relação estabelecida na Figura 4.12a, em termos de resistência à tração da matriz, nota-se que os resultados obtidos para o teor de fibra de $70 \mathrm{~kg} / \mathrm{m}^{3}$ são superiores aos demais teores, com exceção para os valores de $150^{\circ} \mathrm{C}$, cuja influência da temperatura ainda não ocorre de forma significativa, como demonstrado nos resultados anteriores. Também para esta temperatura específica, a influência do teor de fibra de aço não é significativa.

Os valores de resistência à tração pós-fissuração abordados nas diretrizes europeias foram determinados utilizando CMOD $=2,5 \mathrm{~mm}$ para a verificação do ELU, de acordo com o ensaio de flexão preconizado pela EN 14651 (2007). Percebe-se então que os resultados em termos de coeficiente de degradação estão dentro da mesma faixa dos resultados obtidos em ensaios de flexão e são comparáveis aos padrões apresentados pelas normas europeias, visto que os ensaios de flexão tendem a apresentar maiores valores residuais após a exposição a temperatura elevadas. Isto ocorre devido às características intrínsecas ao ensaio de flexão, onde as tensões de tração concentram-se apenas na região abaixo da linha neutra, o que pode gerar má interpretação dos resultados, de forma que os valores podem não ser representativos da estrutura após exposição a elevadas temperaturas. Ressalta-se que, diferentemente do que ocorre no ensaio de flexão, no ensaio DEWS as tensões de tração se distribuem de maneira uniforme ao longo da fissura vertical, na região compreendida entre os entalhes. 
Figura 4.12 - Coeficientes de degradação mecânica em comparação com as normas europeias: (a) resistência à tração da matriz; (b) resistência à tração pós-fissuração associada ao ELU
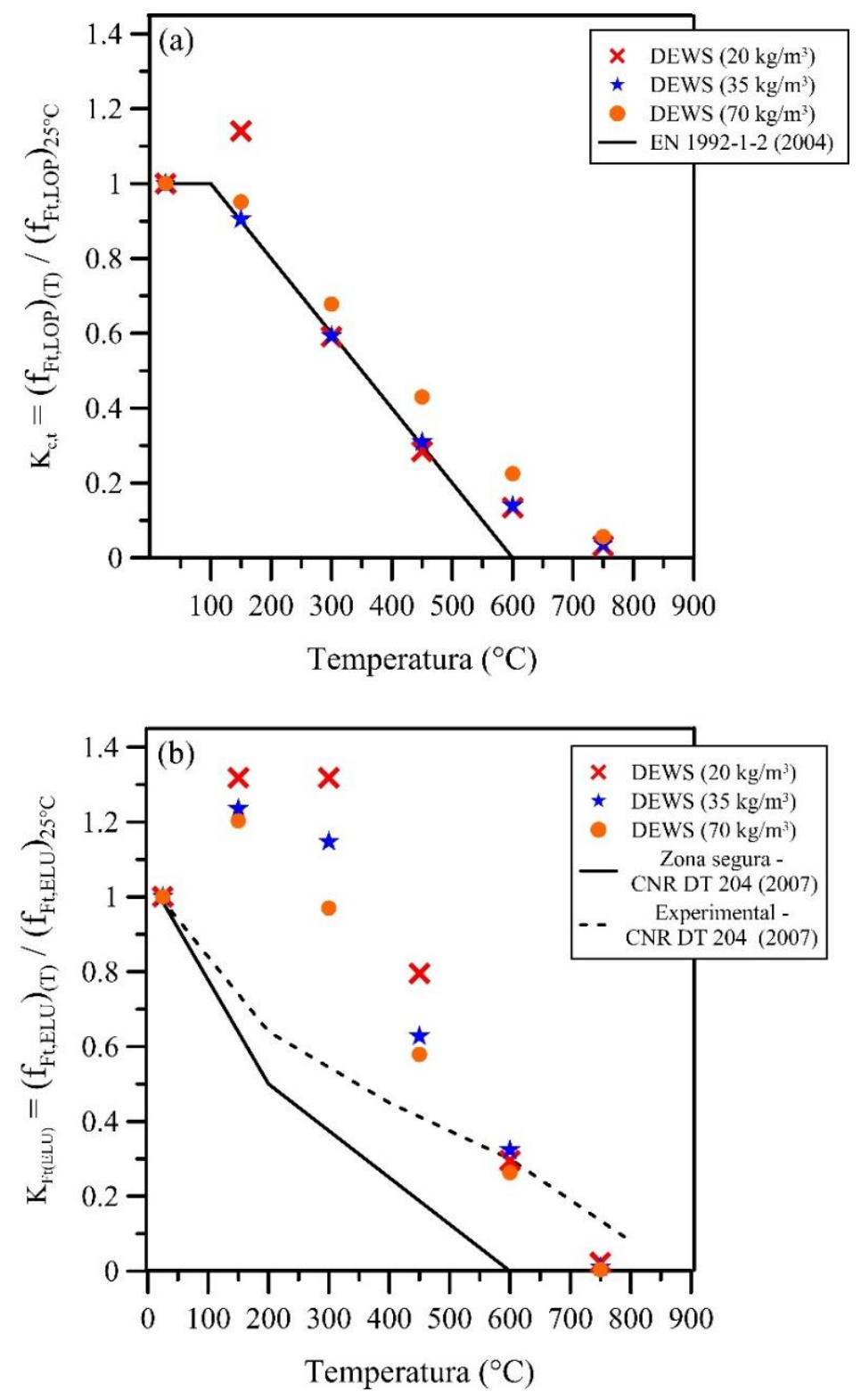

Fonte: Elaborado pelo autor

\subsubsection{Instabilidade pós-fissuração e a determinação da resistência no ensaio DEWS}

Durante a execução do ensaio DEWS ocorreu instabilidade pós-fissuração, a qual atingiu níveis superiores a $0,3 \mathrm{~mm}$, principalmente nas primeiras temperaturas analisadas, o que também foi representada por meio de valores significativos de desvio padrão apresentados na Tabela 4.5. A Figura A4 do Apêndice A retrata de forma ilustrativa a região de instabilidade em uma das curvas individuais experimentais obtida neste estudo. Essa instabilidade gera incertezas na determinação dos valores de resistência residual associados ao ELS, principalmente com o emprego de baixos teores de fibra, como demonstrado para $20 \mathrm{~kg} / \mathrm{m}^{3}$. 
A utilização de um concreto de alta resistência implica em uma matriz frágil e mais susceptível à instabilidade pós-pico, devido à lacuna considerável existente entre a resistência à tração da matriz e as residuais. A utilização de sistema de controle aberto, associado à utilização de uma máquina eletromecânica com baixo valor de rigidez de quadro, pode também ter influenciado a ocorrência de instabilidade pós-pico na temperatura ambiente. Entretanto, para os resultados obtidos após exposição a elevadas temperaturas, devido à deterioração da matriz, a lacuna entre a resistência à tração da matriz (associada à carga de pico) e a resistência associada ao ELS foi menor e, assim, o efeito da instabilidade foi reduzido (Figura A5 do Apêndice A). Sabe-se que a rigidez do equipamento é fixa, enquanto a da amostra é significativamente reduzida com o aumento da temperatura. Assim, a rigidez proporcional do equipamento em relação à amostra aumenta e o ensaio se torna estável, demonstrando que o principal risco de avaliação é na temperatura ambiente, visto que não há degradação da matriz.

A incerteza na determinação dos valores iniciais de resistência pós-fissuração também foi minimizada à medida que aumentou o teor de fibra, de forma que ao utilizar $70 \mathrm{~kg} / \mathrm{m}^{3}$ já não foi mais verificada perda de resistência após a ruptura da matriz (Figura A5 do Apêndice A), o que caracteriza o comportamento de strain-hardening. Entretanto, para os teores de 20 e $35 \mathrm{~kg} / \mathrm{m}^{3}$, o comportamento foi de strain-softening, caracterizado pela redução da capacidade resistente após a ruptura da matriz. Independente do teor utilizado, foi observado um ganho intenso de resistência residual para os menores níveis de abertura de fissura, apresentando-se em evidência quando o teor de fibras foi maior. Este comportamento está atrelado ao elevado módulo de elasticidade do aço (SALVADOR; FIGUEIREDO, 2013), que apresenta grande capacidade de absorção de energia imediatamente após a ruptura, além do uso de fibras com gancho, que favorece sua ancoragem mecânica.

A capacidade de reforço que as fibras de aço proporcionaram foi diretamente proporcional ao teor utilizado, visto que em amostras com teores elevados há uma quantidade maior de fibras na seção de ruptura que podem transferir tensões através das fissuras, de modo que a resistência pós-fissuração dessa seção é a somatória das tensões resistidas por cada fibra presente nesta região. Além disso, no que se refere ao comportamento pós-fissuração, notou-se que os corpos de prova que possuíam maior número de fibras por unidade de volume apresentaram menor dispersão nos resultados, principalmente porque o comportamento apresentado nas curvas não apresentou instabilidade pós-pico. 


\subsection{Efeito do fogo nas propriedades de tração do CRFA}

Após exposição das amostras ao fogo, alterações físicas foram notadas por meio de uma inspeção visual, como a formação de fissuras, o surgimento de uma camada friável de óxido ao redor das fibras de aço (Figuras 4.13 e 4.14a) e uma mudança de coloração das amostras à medida que há um distanciamento da face mais exposta ao fogo (Figura 4.14b). O processo de fissuração excessivo é resultado da expansão desigual das camadas internas do compósito e das tensões térmicas geradas durante exposição ao fogo (BAŽANT; KAPLAN, 1996), o que também está relacionado com as temperaturas elevadas na face mais próxima do fogo.

As Tabelas 4.6 e 4.7 apresentam os resultados de resistência à tração da matriz e resistência à tração pós-fissuração obtidos por meio dos ensaios DEWS e flexão de três pontos, antes e após exposição ao fogo, os quais também são representados nas curvas médias de resistência à tração por abertura de fissura apresentadas na Figura 4.15. Independente do ensaio empregado, as amostras ensaiadas à temperatura ambiente com teores de fibra de 20 e $35 \mathrm{~kg} / \mathrm{m}^{3}(0,26 \%$ e $0,45 \%$ em volume, respectivamente) apresentaram um comportamento de amolecimento (softening) após a carga de fissuração, enquanto as amostras com $70 \mathrm{~kg} / \mathrm{m}^{3}$ de fibra $(0,90 \%$ em volume) apresentaram comportamento de endurecimento (hardening). A adição de fibras não exerceu influência significativa na carga de pico, de modo que independentemente do teor empregado, a resposta elástica inicial apresentou-se praticamente inalterada. Além disso, a presença de microfibras sintéticas garantiu que não ocorresse fragmentação explosiva em nenhuma das amostras expostas ao fogo.

Figura 4.13 - Amostra prismática fissurada após exposição ao fogo, com destaque para as fibras oxidadas

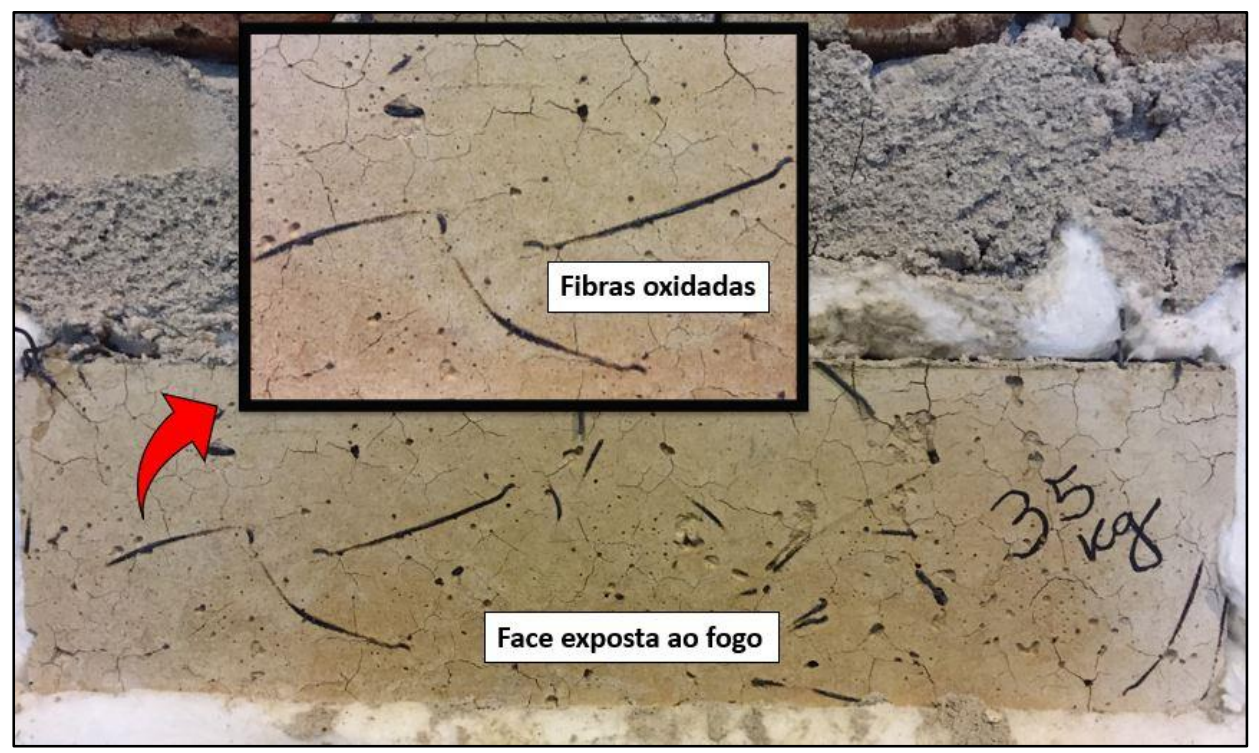

Fonte: Acervo do autor 
Figura 4.14 - Amostras cúbicas com os teores distintos de fibras de aço: (a) Face exposta ao fogo; (b) Vista superior, com destaque para a mudança de cor

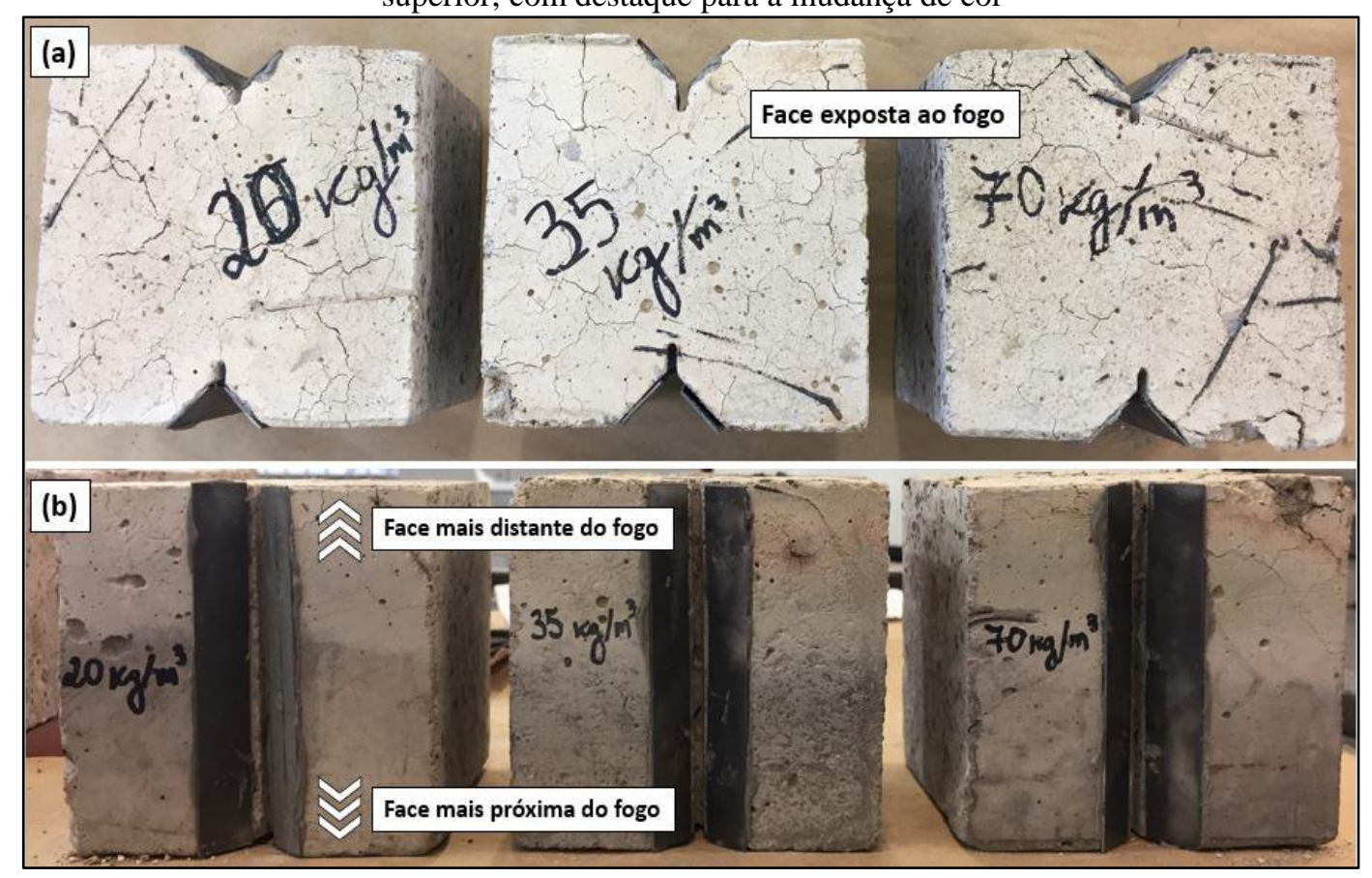

Fonte: Acervo do autor

Tabela 4.6 - Valores médios de resistência à tração da matriz $\left(\mathrm{f}_{\mathrm{tc}}\right)$ e resistências residuais $\left(\mathrm{f}_{\mathrm{t} 0,25}\right.$ e $\left.\mathrm{f}_{\mathrm{t} 1,25}\right)$ obtidos por meio do ensaio DEWS $\left(\mathrm{T}=25^{\circ} \mathrm{C}\right.$ e após exposição ao fogo)

\begin{tabular}{ccccc}
\hline Condição & $\begin{array}{c}\text { Dosagem }\left(\mathrm{kg} / \mathrm{m}^{3}\right) \\
(\% \text { em volume })\end{array}$ & $\mathrm{ftc}(\mathrm{MPa})$ & $\mathrm{ft} 0,25(\mathrm{MPa})$ & $\mathrm{ft} 1,25(\mathrm{MPa})$ \\
\hline \multirow{2}{*}{$25^{\circ} \mathrm{C}$} & $20(0,26 \%)$ & $3,19( \pm 0,63)$ & $1,35( \pm 0,51)$ & $1,19( \pm 0,39)$ \\
& $35(0,45 \%)$ & $3,78( \pm 0,59)$ & $1,90( \pm 0,29)$ & $1,52( \pm 0,32)$ \\
& $70(0,90 \%)$ & $4,05( \pm 0,71)$ & $4,57( \pm 0,79)$ & $2,62( \pm 0,55)$ \\
\hline \multirow{2}{*}{ Pós-fogo } & $20(0,26 \%)$ & $0,65( \pm 0,09)$ & $0,63( \pm 0,07)$ & $0,53( \pm 0,09)$ \\
& $35(0,45 \%)$ & $1,09( \pm 0,16)$ & $0,77( \pm 0,10)$ & $0,58( \pm 0,11)$ \\
& $70(0,90 \%)$ & $1,54( \pm 0,15)$ & $2,05( \pm 0,13)$ & $2,16( \pm 0,17)$ \\
\hline
\end{tabular}

Tabela 4.7 - Valores médios de resistência à tração do compósito $\left(f_{L O P}\right)$ e resistências residuais $\left(f_{R 1}, f_{R 2}, f_{R 3}\right.$ e $\left.f_{R 4}\right)$ obtidos por meio do ensaio de flexão ( $\mathrm{T}=25^{\circ} \mathrm{C}$ e após exposição ao fogo)

\begin{tabular}{ccccccc}
\hline \multirow{2}{*}{ Condição } & $\begin{array}{c}\text { Dosagem } \\
\left(\mathrm{kg} / \mathrm{m}^{3}\right)(\% \\
\mathrm{em} \text { volume })\end{array}$ & $\mathrm{f}_{\mathrm{LOP}}(\mathrm{MPa})$ & $\mathrm{f}_{\mathrm{R} 1}(\mathrm{MPa})$ & $\mathrm{f}_{\mathrm{R} 2}(\mathrm{MPa})$ & $\mathrm{f}_{\mathrm{R} 3}(\mathrm{MPa})$ & $\mathrm{f}_{\mathrm{R} 4}(\mathrm{MPa})$ \\
\hline \multirow{2}{*}{$25^{\circ} \mathrm{C}$} & $20(0,26 \%)$ & $8,53( \pm 0,47)$ & $2,74( \pm 0,46)$ & $1,68( \pm 0,39)$ & $0,99( \pm 0,14)$ & $0,70( \pm 0,12)$ \\
& $35(0,45 \%)$ & $8,42( \pm 0,12)$ & $4,44( \pm 0,81)$ & $3,74( \pm 0,58)$ & $2,72( \pm 0,60)$ & $2,05( \pm 0,62)$ \\
& $70(0,90 \%)$ & $9,31( \pm 0,25)$ & $12,97( \pm 0,42)$ & $11,70( \pm 0,54)$ & $7,70( \pm 0,21)$ & $5,73( \pm 0,41)$ \\
\hline \multirow{2}{*}{ Pós-fogo } & $35(0,45 \%)$ & $0,89( \pm 0,07)$ & $1,90( \pm 0,08)$ & $2,02( \pm 0,28)$ & $1,95( \pm 0,38)$ & $1,86( \pm 0,41)$ \\
& $70(0,90 \%)$ & $1,57( \pm 0,09)$ & $3,66( \pm 0,07)$ & $3,97( \pm 0,27)$ & $3,89( \pm 0,39)$ & $3,77( \pm 0,48)$ \\
\hline
\end{tabular}


Figura 4.15 - Curvas médias de resistência à tração por abertura de fissura do CRFA antes e após exposição ao fogo: (a) ensaio DEWS; (b) ensaio de flexão
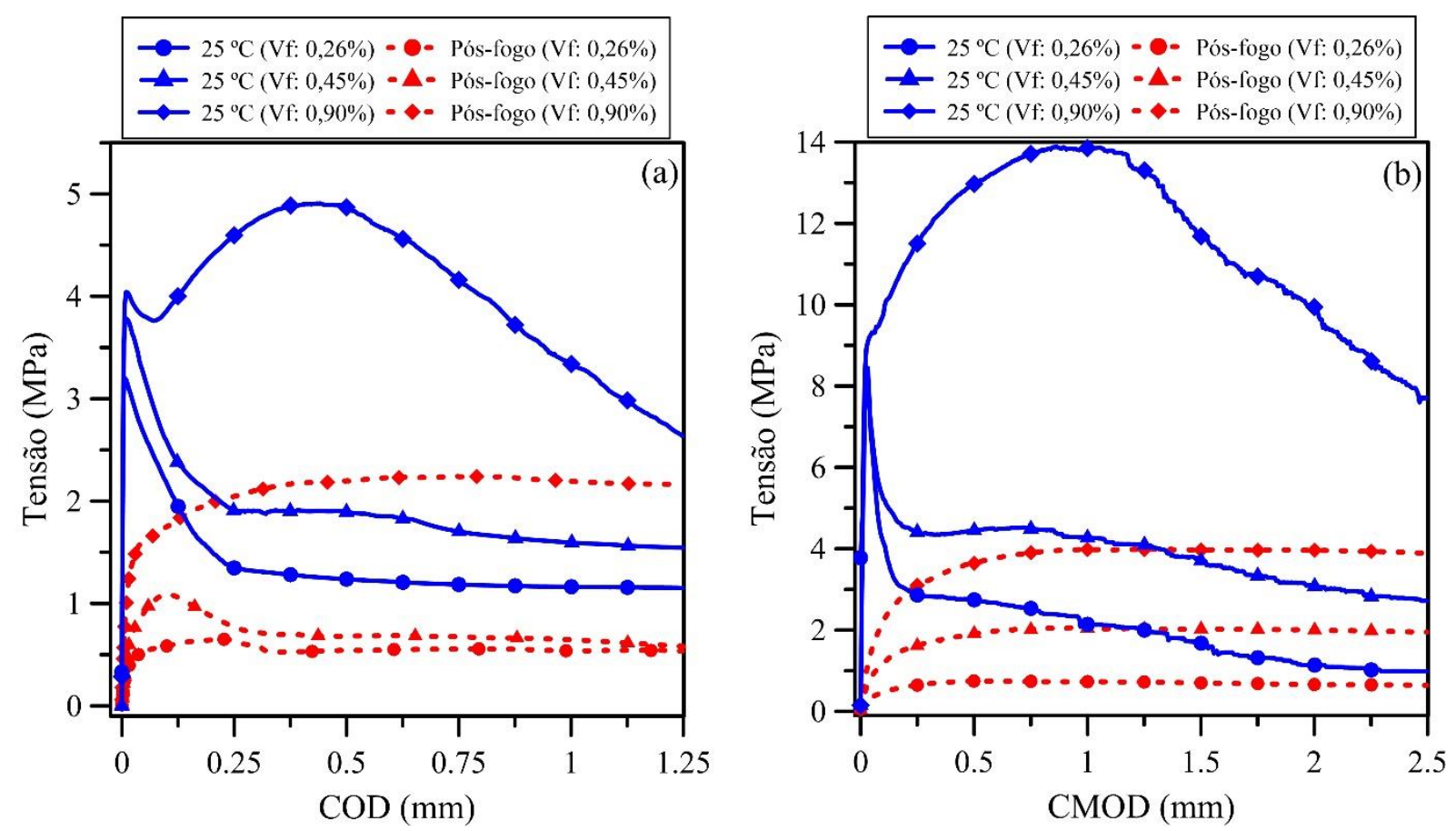

Fonte: Elaborado pelo autor

Analisando os resultados apresentados para as amostras ensaiadas por meio do método DEWS, após exposição ao fogo, constata-se que, em termos de resistência à tração da matriz cimentícia, há reduções de 79,6\%,71,2\% e 62,1\% quando comparada à temperatura ambiente para os teores de fibras de $0,26 \%, 0,45 \%$ e $0,90 \%$ em volume, respectivamente. Nas amostras ensaiadas por meio do ensaio de flexão foram observadas reduções mais acentuadas, com valores de $95,7 \%, 89,4 \%$ e $83,2 \%$ para os mesmos teores de fibra, respectivamente. Essas reduções podem estar associadas à decomposição dos produtos de hidratação da pasta de cimento, redução da área superficial específica dos hidratos e mudanças na distribuição dos poros (MA et al., 2015), além da formação de fissuras provenientes da existência de gradientes de temperatura no concreto, induzidos pela exposição ao fogo.

Por meio da análise das Figuras 4.16a e 4.17a percebe-se que, independente do ensaio adotado, não há relação bem definida entre o aumento do teor de fibras e o aumento da resistência à tração da matriz cimentícia na temperatura ambiente, visto que não há diferença significativa entre os valores encontrados. Por outro lado, após exposição ao fogo, mesmo considerando a variabilidade, os valores de resistência à tração da matriz obtidos para diferentes teores de fibras apresentam diferença significativa entre si e a tendência revela-se bem definida $\left(\mathrm{R}^{2}\right.$ superior a 0,95$)$ com o aumento do teor de fibras. 
Nesse caso, as fibras exerceram papel fundamental no controle de abertura de fissuras originadas durante exposição das amostras a elevadas temperaturas e contribuíram para manter o sistema solidário, preservando a resistência à tração da matriz submetida ao fogo. Assim, o padrão de amortecimento de perda de resistência proporcionado pela fibra observado no Seção 4.3.3 se mantém, independente do ensaio adotado. Isso indica que o maior teor de fibras conferiu às amostras a manutenção de um certo nível de integridade após exposição a elevadas temperaturas, o que acarretou redução da perda de resistência relativa. No caso do ensaio DEWS, a resistência à tração média da matriz é maior para o teor de $0,90 \%$ em volume $(1,54$ $\mathrm{MPa}$ ), o que corresponde a uma variação percentual de 135\% em relação ao teor de $0,26 \%$ (0,65 MPa). Já para o ensaio de flexão, esse comportamento também foi evidenciado, com uma diferença percentual de $\sim 335 \%$ entre os teores mínimo e máximo de fibras.

No ensaio DEWS, mesmo após exposição ao fogo, a ocorrência de um pico associado à ruptura da matriz, ainda que não tão bem definido como o da temperatura ambiente, indica que a porção íntegra do corpo de prova foi responsável por parte da capacidade resistente à tração da matriz. Assim, a área que efetivamente contribui para a resistência do compósito não é necessariamente a área total de fratura dos corpos de prova.

O efeito significativo da temperatura também é ressaltado nas propriedades pós-fissuração do compósito. Após exposição ao fogo, os valores de resistência à tração pós-fissuração obtidos por meio do ensaio DEWS para aberturas de fissura associadas ao ELS apresentaram reduções próximas entre os teores de fibras de $0,26 \%, 0,45 \%$ e $0,90 \%$ em volume, correspondentes a $53,4 \%, 59,5 \%$ e $55,1 \%$, respectivamente. Já para aberturas de fissura associadas ao ELU as reduções foram de 55,5\%, 61,8\% e 17,6\% para os três teores, respectivamente. Para os resultados obtidos através do ensaio de flexão, as reduções nos valores de resistência associados ao ELS para as amostras com teores de fibras de aço de $0,26 \%, 0,45 \%$ e $0,90 \%$ foram de $72,8 \%$, $57,1 \%$ e $71,8 \%$, enquanto que para o ELU foram de $34,8 \%, 28,5 \%$ e $49,5 \%$, respectivamente. Logo, para o ensaio de flexão, a tendência de amortecimento da perda de resistência relativa proporcionada pelo aumento do teor de fibras não foi comprovada.

Os resultados apresentados nas Figuras 4.16b,c e 4.17b,c indicam que as fibras de aço e sua interação com a matriz exerceram um papel fundamental nos valores de resistência à tração pós-fissuração. Seja na temperatura ambiente ou após exposição ao fogo, as amostras que possuíam o maior teor também apresentaram melhor resposta residual, independente do ensaio adotado. As tendências observadas no ELS e ELU são bem definidas para o ensaio DEWS ( ${ }^{2}$ superior a 0,93$)$ e para o ensaio de flexão $\left(R^{2}\right.$ superior a 0,98$)$. 
Atenção maior deve ser dada aos parâmetros referentes ao ELU, os quais representam as condições de segurança da estrutura de CRF. Mesmo após exposição ao fogo, os resultados para o teor de fibras de $0,90 \%$ ainda são consideráveis, inclusive com valores de resistência no ELU superiores aos apresentados na temperatura ambiente para os teores inferiores de fibras. Isso pode garantir que o CRFA apresente uma capacidade mínima de suporte à tração, ductilidade e controle de abertura de fissura, indicando que a estrutura pode permanecer segura, de modo que não colapse após um incêndio. Logo, percebe-se uma grande contribuição do aumento do teor de fibras para a manutenção da capacidade resistente do CRFA após exposição ao fogo, de forma que quanto maior o teor de fibra de aço, maior a garantia de segurança pós-fogo.

Reduções nas propriedades mecânicas pós-fissuração podem estar relacionadas à perda de ancoragem das fibras de aço por degradação da matriz de cimento em seu entorno e a consequente alteração no comportamento de arrancamento das fibras com a temperatura (ABDALLAH et al., 2017; RUANO et al., 2018; SERAFINI et al., 2021), além da degradação da própria fibra, com a perda de capacidade resistente à medida que ocorre a elevação da temperatura. Durante a exposição ao fogo, em virtude da existência de tensões térmicas e fissuras provenientes da exposição a elevadas temperaturas, as fibras podem ter sido solicitadas ainda nesta fase, o que pode ter fomentado a significativa redução nos valores de resistência pós-fissuração. Além disso, visto que as amostras possuíam pequenas espessuras $(1=100 \mathrm{~mm})$, um volume considerável foi afetado de forma intensa pelo fogo, o que também pode justificar as reduções consideráveis no comportamento pós-fissuração.

A avaliação das propriedades pós-fissuração do compósito após exposição ao fogo acaba representando as camadas mais afetadas, já que eventos dessa natureza induz uma composição de propriedades mecânicas internas associadas ao gradiente de temperatura. Em virtude dessa heterogeneidade, a qual é função da distância afetada pelo fogo, a abertura da fissura durante os ensaios também não ocorreu de forma igualitária nos dois lados da amostra. O lado afetado pelo fogo apresentou maiores aberturas, o que reforça a hipótese de que os resultados pósfissuração tendem a representar o comportamento da camada mais afetada. Contudo, não houve esmagamento ou qualquer dano proveniente da interação entre o rolete e o corpo de prova, mesmo no ensaio DEWS, o qual provou ser um método tecnicamente viável de avaliação da resistência à tração pós-fissuração do CRFA após ser submetido ao fogo. 
Figura 4.16 - Correlação entre as resistências médias e o teor de fibras por meio do ensaio DEWS $\left(25^{\circ} \mathrm{C}\right.$ e pósfogo): (a) resistência à tração da matriz; (b) resistência residual em $0,25 \mathrm{~mm}$; (c) resistência residual em 1,25 mm

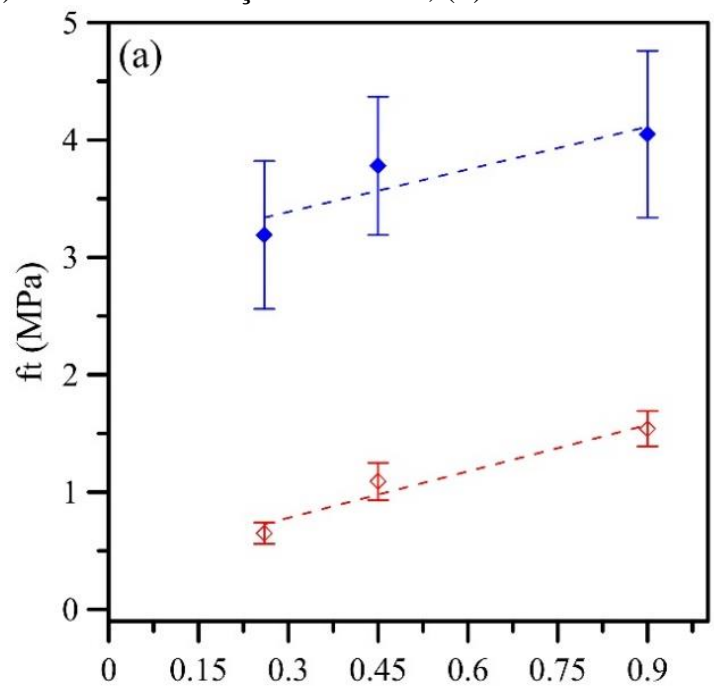

Dosagem de fibra ( $\%$ em volume)
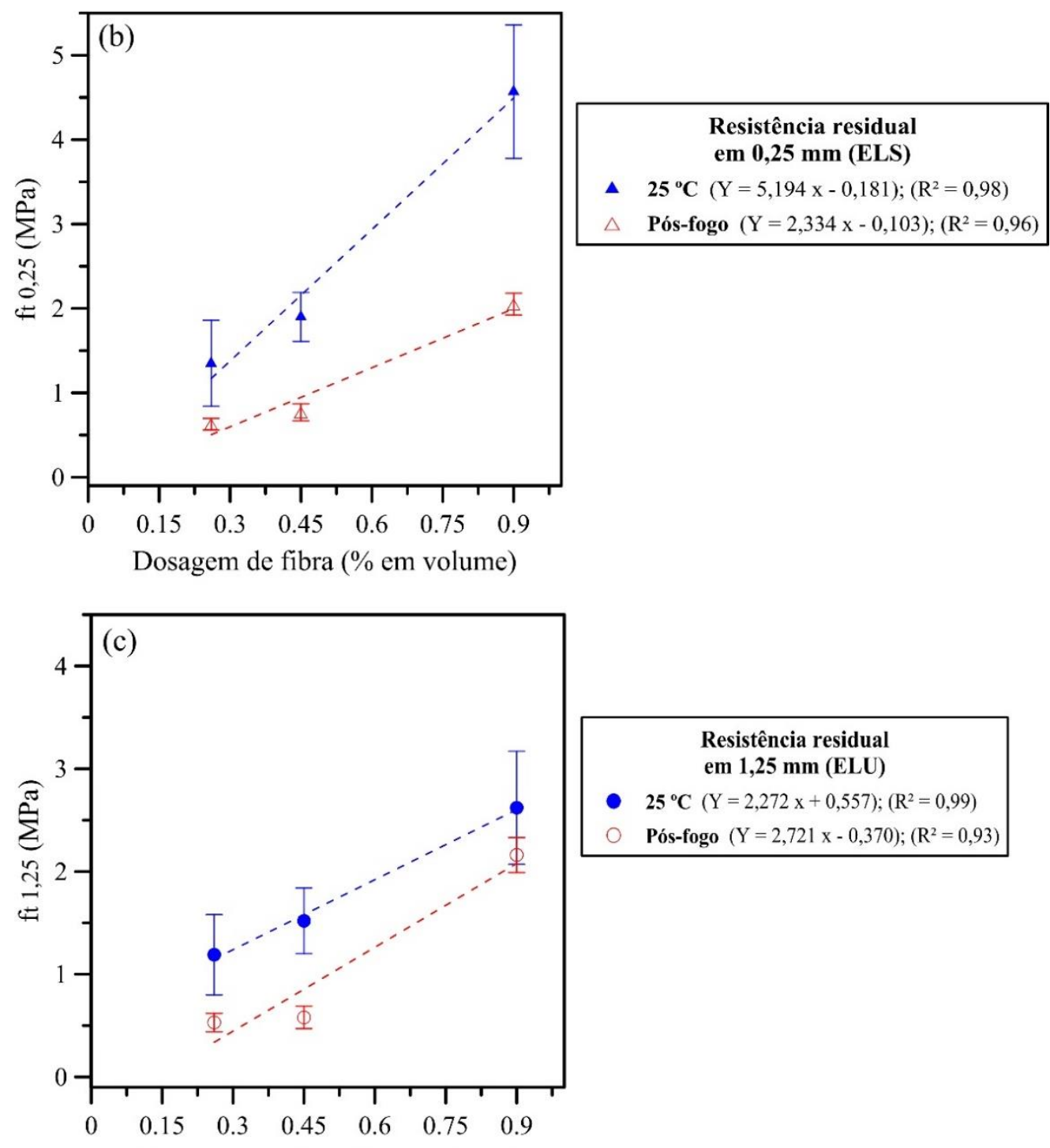

Dosagem de fibra ( $\%$ em volume)

Fonte: Elaborado pelo autor 
Figura 4.17 - Correlação entre as resistências médias e o teor de fibras por meio do ensaio de flexão $\left(25^{\circ} \mathrm{C}\right.$ e pósfogo): (a) limite de proporcionalidade; (b) resistência residual para CMOD $=0,5 \mathrm{~mm}$ (c) resistência residual para $\mathrm{CMOD}=2,5 \mathrm{~mm}$

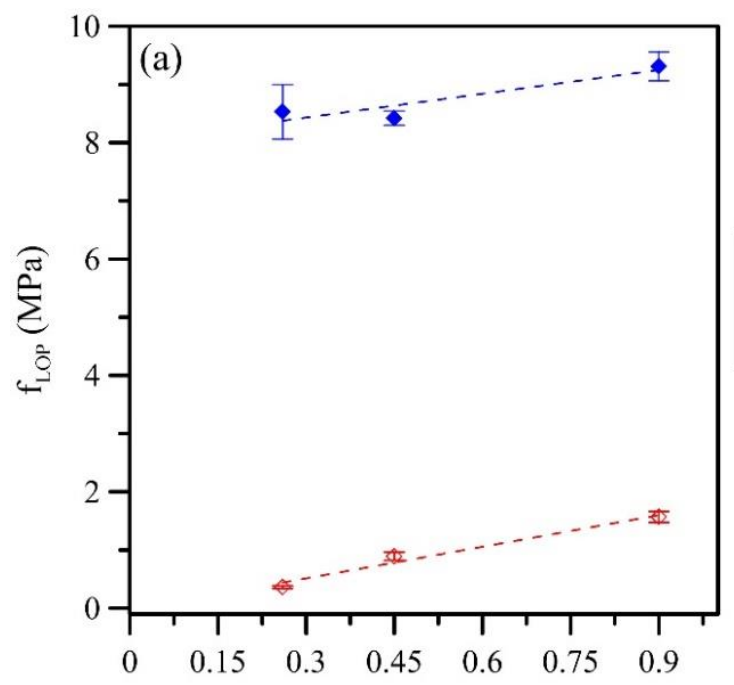

Limite de Proporcionalidade

- $\quad 25^{\circ} \mathrm{C}(\mathrm{Y}=1,363 \mathrm{x}+8,023) ;\left(\mathrm{R}^{2}=0,84\right)$

$\diamond \quad$ Pós-fogo $(\mathrm{Y}=1,811 \mathrm{x}-0,032) ;\left(\mathrm{R}^{2}=0,97\right)$

Dosagem de fibra (\% em volume)

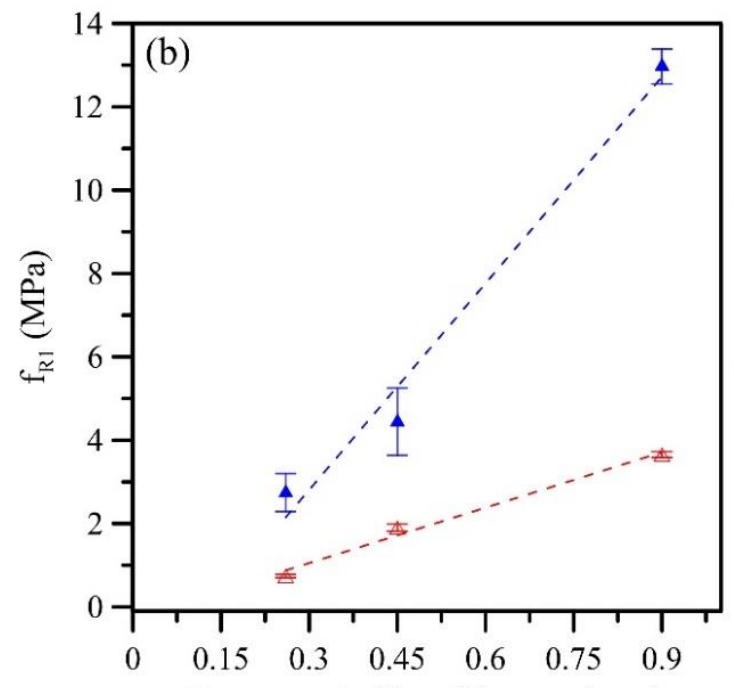

Resistência residual à tração na flexão para CMOD $=0,5$ mm (ELS)

- $25^{\circ} \mathrm{C}(\mathrm{Y}=16,511 \mathrm{x}-2,143) ;\left(\mathrm{R}^{2}=0,98\right)$

$\triangle \quad$ Pós-fogo $(\mathrm{Y}=4,431 \times-0,276) ;\left(\mathrm{R}^{2}=0,99\right)$

Dosagem de fibra (\% em volume)

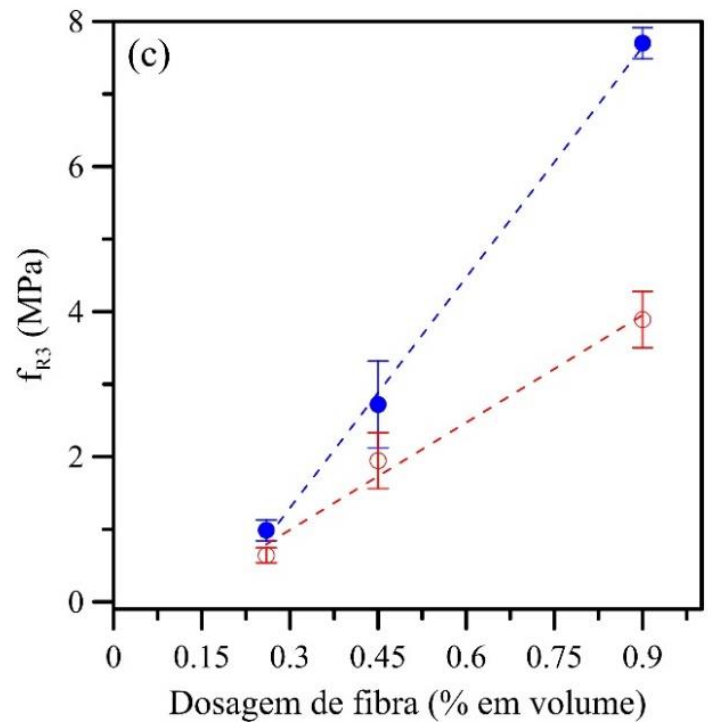

Resistência residual à tração na

flexão para CMOD = 2,5 mm (ELU)

- $25^{\circ} \mathrm{C}(\mathrm{Y}=10,594 \mathrm{x}-1,883) ;\left(\mathrm{R}^{2}=0,99\right)$

Pós-fogo $(\mathrm{Y}=4,936 \mathrm{x}-0,489) ;\left(\mathrm{R}^{2}=0,99\right)$

Fonte: Elaborado pelo autor 
À temperatura ambiente, independente do ensaio e do teor de fibra de aço, a resistência pós-fissuração associada ao ELU apresentou-se inferior à associada ao ELS. Entretanto, após exposição ao fogo, tais valores apresentaram-se praticamente constantes, de modo que a análise estatística não indica diferenças significativas.

Após exposição ao fogo, as reduções em termos de resistência à tração pós-fissuração associada ao ELU tenderam a ser mais brandas que as apresentadas para a resistência à tração da matriz, principalmente porque o mecanismo de arrancamento das fibras de aço com gancho não é significativamente afetado até $\sim 400^{\circ} \mathrm{C}$ (ABDALLAH et al., 2017; RUANO et al., 2018; SERAFINI et al., 2021). Em alguns casos, não houve diferença significativa no ELU entre valores da temperatura ambiente e após exposição ao fogo. Quando a avaliação pós-fogo é feita por meio do ensaio de flexão, reduções brandas podem estar relacionadas com alterações na posição da linha neutra das amostras prismáticas à medida que a abertura de fissura aumenta, apresentando-se mais distante da face afetada pelo fogo. Consequentemente, a região de tração na flexão passa a apresentar temperaturas máximas mais brandas.

\subsubsection{Relação entre os ensaios de flexão e DEWS}

Verificou-se uma maior estabilidade nos resultados do ensaio de flexão em relação ao ensaio DEWS, por ter sido realizado em equipamento provido de sistema fechado de controle de velocidade, com baixa dispersão dos resultados, o que garante um maior nível de precisão na avaliação. Ainda assim, foi possível verificar a contribuição das fibras, por meio da variação do seu teor, em ambos os ensaios.

Nota-se que, para os resultados do ensaio de flexão à temperatura ambiente, os valores de coeficiente de variação associados à resistência à tração da matriz e às resistências à tração pósfissuração associadas ao ELS e ELU ficaram abaixo dos 25\%, apresentando-se menor que $10 \%$ para o teor de fibra de 0,90\% em volume. Para os resultados do ensaio DEWS, a variabilidade associada à resistência à tração pós-fissuração para o teor mais baixo de fibra apresentou-se superior a 30\%, entretanto, assim como nos resultados de flexão, os maiores teores apresentaram menores valores de coeficientes de variação, entre 15 e $20 \%$. Assim, o grau de dispersão dos resultados foi inversamente proporcional ao teor de fibras, o que está relacionado com o número de fibras presente na seção de ruptura que, sendo elevado, tem sua capacidade de reforço menos sujeita a pequenas variações na quantidade e direcionamento das fibras. 
Todavia, para os resultados obtidos após exposição ao fogo, devido à deterioração da matriz, a lacuna entre as resistências à tração da matriz e a residual associada ao ELS é menor e, assim, o efeito da instabilidade no ensaio DEWS é atenuado. Além disso, embora a utilização do sistema fechado de controle de velocidade propicie redução na variabilidade do resultado experimental, ambos os ensaios possuem entalhes que induzem a formação e o posicionamento da fissura na região do seu plano, minimizando a dissipação de energia na amostra. Nos dois ensaios, após exposição ao fogo, os valores de coeficiente de variação obtidos associados à resistência à tração da matriz e às resistências à tração pós-fissuração associadas ao ELS e ELU ficaram abaixo dos $20 \%$, apresentando-se menor que $10 \%$ para o teor de fibra de $0,90 \%$.

Comparando os resultados dos ensaios de flexão e DEWS, nota-se que suas respostas são significativamente diferentes, tanto para a temperatura ambiente, quanto após a exposição ao fogo, independente do teor de fibra empregado. As diferenças apresentadas estão relacionadas à própria configuração dos ensaios, o que envolve fatores geométricos e esforços atuantes. Embora sejam aplicadas tensões de tração nas amostras, sua natureza e as deformações associadas não são as mesmas nos dois ensaios. O DEWS é um ensaio cuja resposta se aproxima ao ensaio de tração direta, apresentando resultados menores em termos de tensão. Neste ensaio, as tensões máximas de tração atuam em toda a superfície de fratura da amostra, de forma distinta ao que ocorre no ensaio de flexão, cujas tensões máximas de tração apresentam-se concentradas na superfície inferior da amostra, abaixo da linha neutra. Esse cenário pode acarretar valores mais altos de resistência à tração em ensaios de flexão, o que indica que resultados provenientes do ensaio DEWS podem estar a favor da garantia da segurança estrutural do CRFA.

Apesar de serem constatadas divergências nas respostas dos ensaios DEWS e de flexão, uma correlação global entre os resultados foi estabelecida, em níveis de resistência à tração da matriz e resistências pós-fissuração associadas ao ELS e ELU. O diagrama de dispersão indica que há uma relação linear positiva, apresentando coeficiente de correlação $R^{2}=0,95$ ao considerar todos os teores estudados (Figura 4.18). Nota-se que a equação obtida a partir da regressão linear é semelhante à equação de resistência à tração pós-fissuração sob tensão uniaxial $\mathrm{f}_{\text {Ftu }}$ para o Modelo Rígido-Plástico apresentado no fib Model Code 2010. Trata-se de uma hipótese de leis constitutivas de pós-fissuração que podem ser utilizadas para aplicação em seções solicitadas normalmente à tração. Neste Modelo, o valor de referência único baseado no comportamento último, $\mathrm{f}_{\mathrm{Ftu}}$, resulta do pressuposto de que toda resistência de compressão é concentrada na parte superior da seção e é definido como um terço de $f_{\mathrm{R} 3}$, isto é, função da tensão obtida no ensaio de flexão para uma abertura de fissura de 2,5 mm (ELU). 
Pelo gráfico da Figura 4.18, o valor da tensão obtida no ensaio de flexão é cerca de 3 vezes o valor do DEWS, o que está em concordância com o fator de conversão adotado pelo fib Model Code 2010 (FIB, 2013).

Figura 4.18 - Correlação global média entre as tensões obtidas pelos ensaios de flexão e DEWS

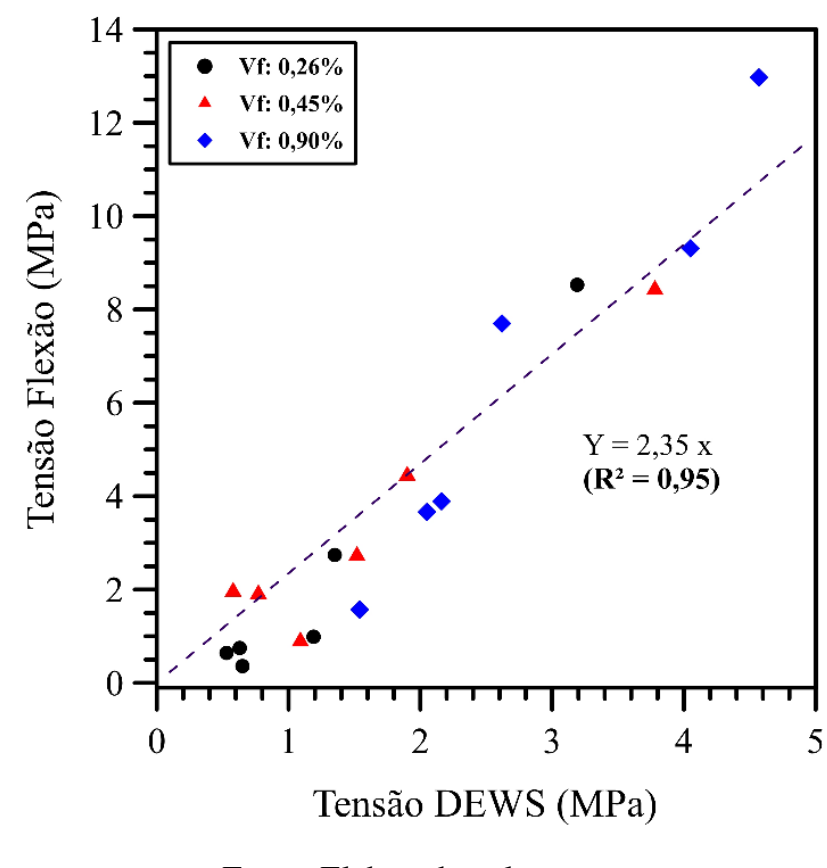

Fonte: Elaborado pelo autor

\subsubsection{Gradiente de temperatura e relação com os resultados em temperaturas específicas}

Serafini et al. (2019a), por meio de correlações envolvendo temperatura, tempo e distância da face afetada pelo fogo, avaliaram os gradientes de temperatura no interior de amostras de CRFP. Vale ressaltar que esse concreto também foi produzido com base nas especificações do Metrô de São Paulo, cuja composição da matriz cimentícia foi a mesma deste estudo. Foi possível constatar que para distâncias de 3,6, 9, 12 e $15 \mathrm{~cm}$ da face afetada diretamente pelo fogo as temperaturas registradas foram de $612,403,212,141$ e $112{ }^{\circ} \mathrm{C}$, respectivamente, para uma duração de incêndio de 120 min (Figura 4.19). Essa variação de temperatura possui relação com o baixo coeficiente de condutividade térmica do concreto, que não é alterado de forma significativa pelo tipo e adição de fibras (LIU et al., 2017), e contribui para preservar uma parcela considerável da resistência mecânica do compósito em seções distantes do fogo.

A existência de gradientes de temperatura no interior do compósito após exposição ao fogo ressalta a importância dos resultados obtidos em forno elétrico apresentados na Seção 4.3.3, onde há homogeneização de temperaturas específicas no interior do compósito. Por meio desses resultados é possível determinar a degradação heterogênea proporcionada pelo fogo no interior 
da amostra, constituindo ferramenta útil para avaliação experimental do comportamento mecânico do CRFA após exposição ao fogo. Pode servir, inclusive, de base para a definição de parâmetros de segurança aplicados às estruturas de CRFA expostas ao fogo e como dados de entrada para validar modelos numéricos.

Figura 4.19 - Distribuição da temperatura no interior das amostras de CRF em função da distância da face afetada pelo fogo e tempo de exposição ao fogo

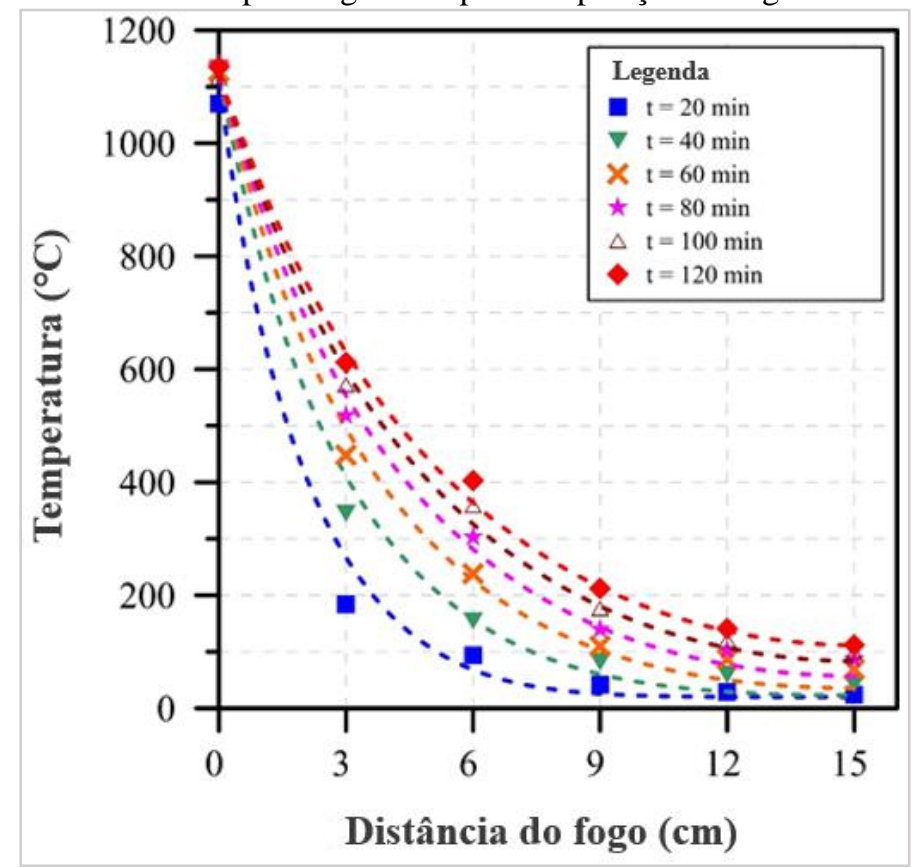

Fonte: Adaptado de Serafini et al. (2019a)

Portanto, é possível relacionar temperaturas específicas encontradas no interior do compósito após exposição ao fogo com as propriedades mecânicas por camada afetada. Os resultados de resistência à tração pós-fissuração obtidos para a temperatura de $600{ }^{\circ} \mathrm{C}$ na Seção 4.3.3 - temperatura aproximada obtida a $3 \mathrm{~cm}$ da face diretamente afetada pelo fogo corroboram com os apresentados por Serafini et al. (2020b) que constataram redução de 77\% nesta propriedade em comparação com a temperatura ambiente.

Por outro lado, seções mais internas preservaram uma parcela significativa da resistência à tração pós-fissuração, o que tem relação com a baixa influência da temperatura no comportamento de arrancamento das fibras de aço até $\sim 450{ }^{\circ} \mathrm{C}$ (ABDALLAH et al., 2017; RUANO et al., 2018; SERAFINI et al., 2021). Isso indica que as propriedades pós-fissuração relacionadas à tração do compósito podem ser preservadas em camadas mais internas, garantindo capacidade de reforço para as estruturas de CRFA, especialmente quando se utiliza teores mais elevados de fibras, como demonstrado para o teor de $0,90 \%$ em volume. 
Logo, mesmo que o compósito apresente deterioração significativa na face exposta ao fogo, isso não significa necessariamente que há perda de toda condição de estabilidade. Além disso, como as propriedades mecânicas internas variam em função da temperatura, isso é um fator que deve ser levado em conta na etapa de projeto em ordem de garantir a segurança estrutural do elemento de CRFA, principalmente quando a demanda à tração na flexão é alta.

A análise dos resultados do ensaio DEWS após exposição ao fogo indica que os valores médios de $\mathrm{f}_{\mathrm{t}}$ e $\mathrm{f}_{\mathrm{t} 1,25}$ (associado ao ELU) tendem aos resultados obtidos para $\mathrm{T}=450{ }^{\circ} \mathrm{C}$ (Ver Seção 4.3.3). Isso é observado em todos as curvas médias tensão-COD, independente do teor de fibras empregado. Trata-se de um forte indicativo que essas curvas representam uma composição média dos resultados apresentados por camada afetada da amostra, visto que em cubos de $10 \mathrm{~cm}$, durante o incêndio, a temperatura pode variar entre $600{ }^{\circ} \mathrm{C}-\mathrm{em}$ regiões próximas à face diretamente atingida pelo fogo - e $300^{\circ} \mathrm{C}$ - na face mais distante do fogo.

\subsubsection{Influência do fator escala nos resultados de flexão e DEWS}

Foi estabelecida uma correspondência dos resultados deste estudo com os valores obtidos no estudo de Serafini et al. (2020b), em termos de resistências à tração da matriz cimentícia e pós-fissuração em ambos os ensaios - DEWS e flexão - como apresentado na Figura 4.20. A utilização dos resultados em temperaturas específicas, juntamente com os de exposição ao fogo, explica a quantidade significativa de pontos apresentados na correlação do ensaio DEWS. No que se refere especialmente a este método, pode-se verificar uma tendência bem definida $\left(\mathrm{R}^{2}=\right.$ $0,97)$ entre resultados obtidos com corpos de prova cúbicos de dimensões distintas, visto que Serafini et al. (2020b) utilizaram amostras com $15 \mathrm{~cm}$ de aresta. Verifica-se que, apesar das diferenças significativas entre os estudos no que se refere aos valores de carga aplicada nas amostras, em termos de tensão existe equivalência de resultados. $\mathrm{O}$ fator escala próximo de 1 indica que é possível fazer a conversão dos valores, os quais em termos de tensão, são equivalentes, independente da temperatura.

No que se refere ao ensaio de flexão, o fator de conversão indica que existe uma influência maior de escala em relação ao DEWS, porém seriam necessários mais ensaios e, consequentemente, mais pontos de correlação para estabelecer a correspondência de forma mais confiável. Entretanto, observou-se que as curvas carga versus abertura de fissura obtidas seguiram o mesmo padrão, indicando que a mudança de escala não interferiu no comportamento à flexão do compósito. 
Figura 4.20 - Relação com as tensões obtidas por Serafini et al. (2020b): (a) ensaio DEWS; (b) ensaio de flexão
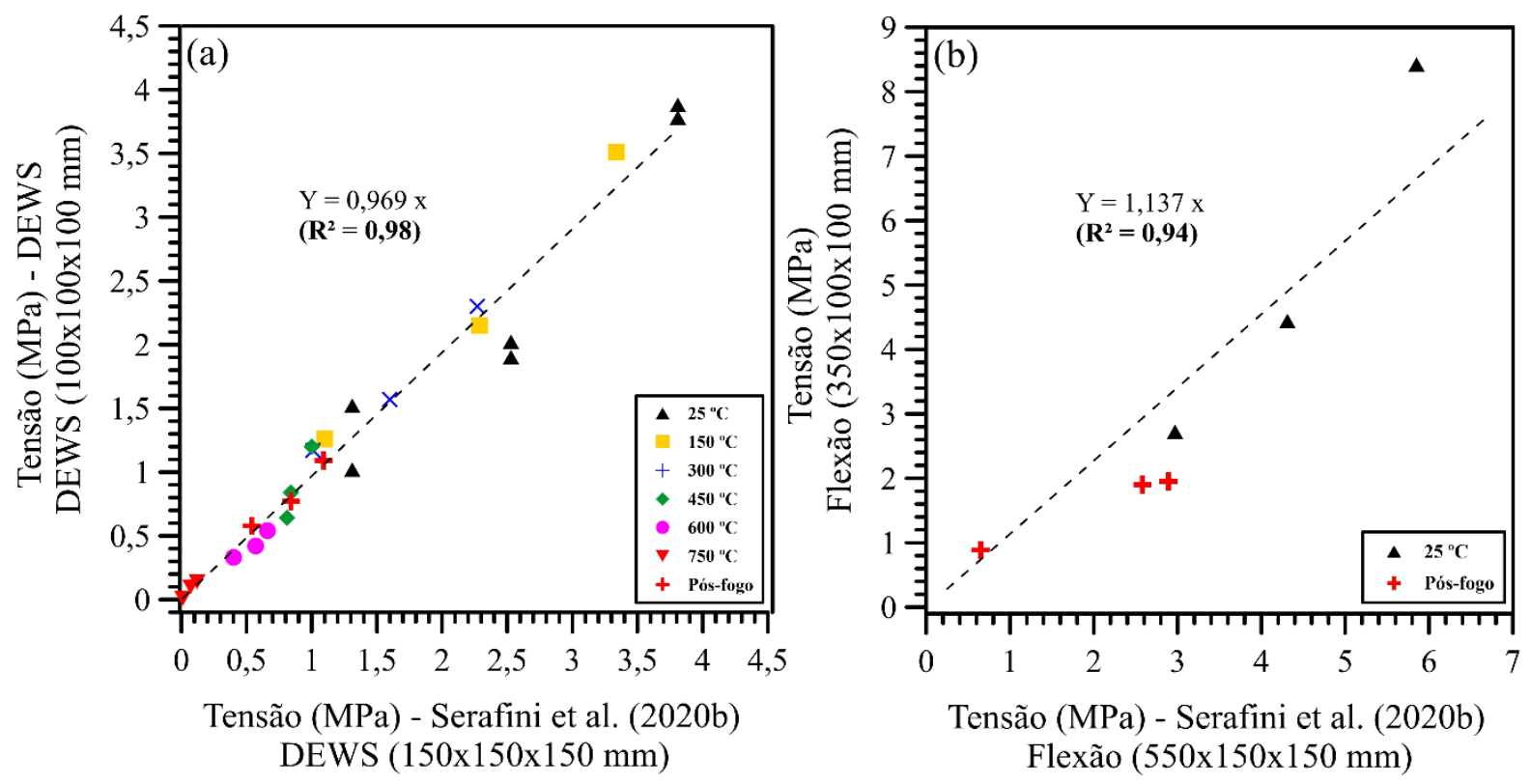

Fonte: Elaborado pelo autor

\subsubsection{Relação entre as resistências à compressão e à tração}

Verificou-se também a relação entre os valores de resistência à tração obtidos pelo ensaio DEWS e resistência à compressão do CRFA, por meio de uma correlação estabelecida entre os resultados e apresentada na Figura 4.21. Obteve-se excelente aderência da curva de tendência aos dados experimentais, com $\mathrm{R}^{2}=0,98$. Em média, o valor de resistência à tração obtido por meio do ensaio DEWS representou em torno de $4 \%$ do valor de resistência à compressão. Por meio da correlação estabelecida, um concreto que apresente $90 \mathrm{MPa}$ de resistência à compressão, possui $3,82 \mathrm{MPa}$ de resistência à tração. Essa relação também é válida após exposição do CRF a temperaturas específicas, o que permite estimar o valor de resistência à tração quando são conhecidos os valores de resistência à compressão, assim como o inverso. Vale ressaltar que as relações são válidas para a dosagem específica de concreto utilizada neste estudo e com a determinação da resistência à tração por meio do ensaio DEWS.

Ao empregar o ensaio de flexão, percebe-se que as relações são outras, de modo que o valor de resistência à tração na flexão representou em torno de $10 \%$ do valor de resistência média à compressão. Isto é esperado, uma vez que a resposta do material a esforços de tração varia em função do ensaio empregado. Ensaios de tração direta do concreto dificilmente são aplicados, porque os dispositivos de fixação dos corpos de prova podem introduzir tensões secundárias e os resultados são influenciados pela forma de se proceder à tração na máquina de ensaio 
(MEHTA; MONTEIRO, 2008). Existe então o desafio de aplicar uma força de tração pura sem excentricidades (NEVILLE, 1997). Os ensaios de flexão surgiram como alternativa para determinar de modo indireto a resistência à tração do concreto, no entanto, a hipótese de distribuição linear de tensões (hipótese de Navier) não se aplica nesta condição e os valores obtidos são, aproximadamente, o dobro dos valores de resistência à tração axial (GIONGO, 2007). Isto justifica a relação de proporção entre as resistências à tração na flexão e à compressão ser maior que a obtida por meio do ensaio DEWS, o qual se assemelha a um ensaio de tração direta.

Figura 4.21 - Relação entre as tensões obtidas pelos ensaios de resistência à compressão e DEWS

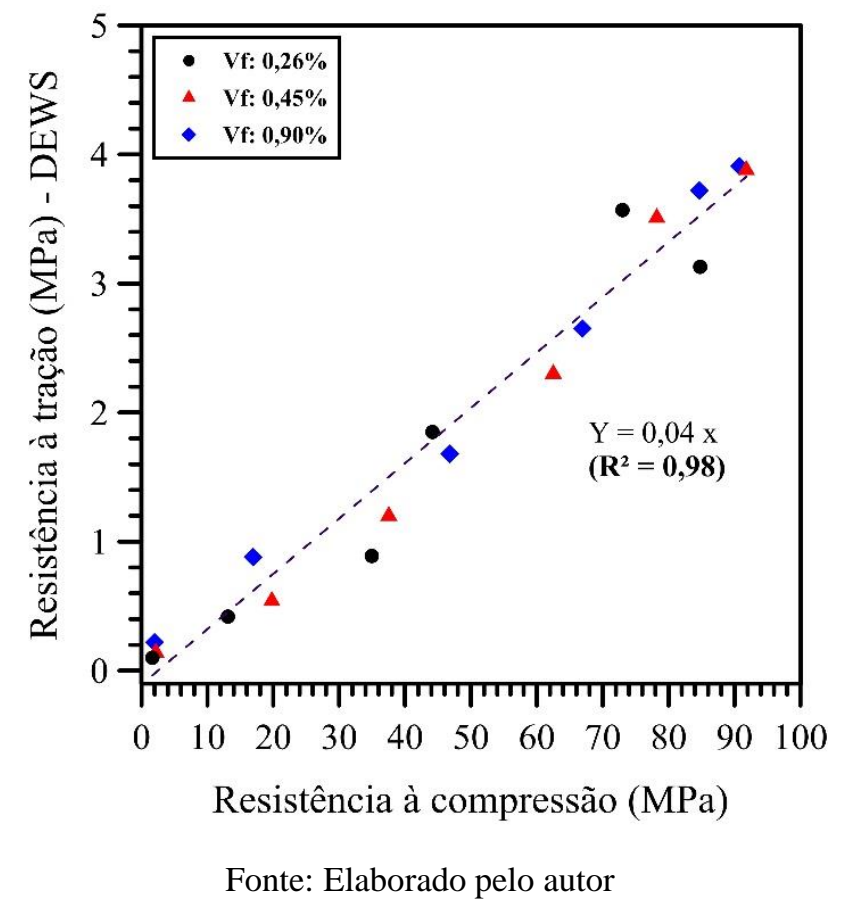




\section{CONCLUSÕES}

O presente estudo avaliou os efeitos da exposição de amostras de CRFA a elevadas temperaturas, verificando a influência do teor de fibras de aço nas mudanças de comportamento mecânico. Esses resultados geram um importante retorno à sociedade, à medida que visam estabelecer parâmetros de comportamento em condições de incêndio de elementos estruturais executados com CRFA. Logo, contribuem para minimizar os riscos e proporcionar segurança aos usuários, ratificando sua relevância social. Os parâmetros de resistência à compressão e à tração, assim como o módulo de elasticidade, foram afetados pela elevação da temperatura. $\mathrm{O}$ comportamento pós-fissuração do compósito variou conforme a temperatura de exposição e o regime de aquecimento adotado. A partir dos resultados obtidos, pode-se concluir que:

- Após exposição à $600{ }^{\circ} \mathrm{C}$ as amostras preservavam apenas 20\% da sua resistência à compressão inicial, independente do teor de fibras empregado, de forma que em $750{ }^{\circ} \mathrm{C}$ já não apresentavam capacidade resistente significativa. Apesar da deterioração intensa da resistência à compressão, sua taxa de degradação ocorreu de forma distinta ao longo das temperaturas de exposição, em função do teor de fibras de aço empregado. Até $450{ }^{\circ} \mathrm{C}$, notou-se um efeito benéfico proporcionado pelas fibras, visto que as amostras com maior teor ( $0,90 \%$ em volume) apresentaram reduções mais brandas $\left(\sim 0,10 \mathrm{MPa} /{ }^{\circ} \mathrm{C}\right)$ em relação aos grupos com teores inferiores $\left(\sim 0,20 \mathrm{MPa} /{ }^{\circ} \mathrm{C}\right)$. As fibras podem ter atuado impedindo que o aumento da porosidade do concreto e a consequente perda de resistência à compressão ocorressem de forma intensa.

- Com a elevação da temperatura, as reduções nos valores de módulo de elasticidade estático se apresentaram próximas entre as amostras com teores distintos de fibra de aço, visto que é uma propriedade que tem relação direta com o volume de sólidos da amostra e independe do teor de fibra utilizado. Após exposição à $450^{\circ} \mathrm{C}$, o CRFA conversava apenas $15 \%$ do valor do módulo de elasticidade obtido na temperatura ambiente.

- O teor de fibras de aço alterou a perda de resistência à tração da matriz $\left(\mathrm{f}_{\mathrm{ct}}\right)$ em relação ao concreto convencional. Observou-se para o teor de $70 \mathrm{~kg} / \mathrm{m}^{3} \mathrm{um}$ efeito positivo ao reduzir a taxa de degradação de $\mathrm{f}_{\mathrm{ct}}$, de modo que após exposição a 450 e $600{ }^{\circ} \mathrm{C}$, as amostras conservavam, respectivamente, $\sim 45 \%$ e $\sim 25 \%$ da resistência inicial, enquanto os demais teores conservaram apenas $\sim 30 \%$ e $\sim 15 \%$ do valor obtido na temperatura ambiente. No entanto, independente do teor de fibra empregado, o valor de $\mathrm{f}_{\mathrm{ct}}$ obtido após exposição a $750{ }^{\circ} \mathrm{C}$ correspondeu a $\sim 5 \%$ do valor obtido na temperatura ambiente, o que em termos práticos significa ausência de capacidade resistente. 
- As reduções nos valores de resistência pós-fissuração não ocorreram com a mesma intensidade que as reduções de propriedades mecânicas da matriz. Independente da temperatura analisada, houve influência positiva do volume de fibra de aço na capacidade resistente pósfissuração do CRF. Notou-se um aumento em termos de ductilidade até $450{ }^{\circ} \mathrm{C}$, entretanto a elevação da temperatura provoca a degradação da matriz cimentícia, o que afeta a capacidade resistente do compósito. A partir desta temperatura $\left(\sim 450^{\circ} \mathrm{C}\right)$, as fibras perdem sua capacidade de reforço, pois têm suas condições de integridade e aderência com a matriz afetadas, o que gerou reduções gradativas nos valores de resistência pós-fissuração associados ao ELS e ELU. Não foi verificada influência das fibras na redução da taxa de degradação desses parâmetros e, independente do teor adotado verificou-se que, após aquecimento a $600{ }^{\circ} \mathrm{C}$, as amostras conservavam apenas $30 \%$ da sua resistência à tração pós-fissuração associada ao ELU. No entanto, os coeficientes de degradação mecânica obtidos apresentaram-se a favor da segurança em relação às normativas internacionais.

- Após exposição das amostras ao fogo, reduções significativas em termos de resistência à tração da matriz e pós-fissuração foram observadas, de modo que o cenário mais desfavorável entre os teores de fibra deste estudo ocorreu quando se utilizou o menor deles. Notou-se coerência com os resultados obtidos após aquecimento em forno elétrico, onde o maior teor de fibras reduziu a perda de resistência à tração, contribuindo para a manutenção de um certo nível de integridade das amostras e, também, da sua capacidade resistente. Isto sugere que a estrutura pode permanecer segura, de modo que não colapse após um incêndio, visto que o CRFA pode apresentar capacidade de suporte à tração.

- Após exposição das amostras de CRFA ao fogo, notou-se que os valores médios de $\mathrm{f}_{\mathrm{t}} \mathrm{e}$ $\mathrm{f}_{\mathrm{t} 1,25}$ (associado ao ELU) obtidos por meio do ensaio DEWS tendem aos resultados obtidos para a temperatura de $450{ }^{\circ} \mathrm{C}$, independente do teor de fibra de aço empregado. Isso indica que os valores obtidos representam uma composição média dos resultados apresentados por camada afetada da amostra, visto que em cubos de $10 \mathrm{~cm}$, a temperatura pode variar entre $600{ }^{\circ} \mathrm{C}-\mathrm{em}$ regiões próximas à face diretamente atingida pelo fogo - e $300^{\circ} \mathrm{C}$ - na face mais distante do fogo. Assim, mesmo que aduelas pré-moldadas, cuja espessura é superior a $10 \mathrm{~cm}$, apresentem deterioração significativa na face exposta ao fogo, isso não significa necessariamente que há perda de toda condição de estabilidade e comportamento mecânico da estrutura de CRFA.

- Os valores de coeficiente de variação obtidos nos ensaios de flexão e DEWS ficaram abaixo dos $20 \%$, apresentando-se menor que $10 \%$ para o maior teor de fibra. Além disso, 
observou-se uma perfeita correlação entre os resultados dos ensaios, de modo que o valor da tensão obtida no ensaio de flexão apresentou-se cerca de 3 vezes o valor do ensaio DEWS, o que apresenta coerência com o fator de conversão adotado pelo fib Model Code. Isto demonstra que o ensaio DEWS, mesmo realizado em máquinas com sistema aberto de controle de velocidade, é efetivo na avaliação do comportamento pós-fissuração do CRF exposto a elevadas temperaturas, constituindo uma metodologia tecnicamente viável nestas condições. Além disso, não houve danos à amostra devido às condições de contato com os roletes e a avaliação ocorreu sem grandes distorções em relação ao CRF ensaiado na temperatura ambiente. Logo, a avaliação ocorreu sem haver prejuízo aos valores obtidos como resposta do material.

- Apesar do ensaio DEWS demandar uma extensa etapa de preparação dos corpos de prova, o que exige cuidados em termos de procedimento experimental, utilizar cubos de pequenas dimensões proporcionou algumas vantagens em relação às amostras prismáticas, como o manuseio de amostras mais leves e menor duração dos ensaios. A amostra prismática torna a determinação da primeira fissura na condição pós-fogo mais complicada por facilitar a ocorrência de danos em relação aos cubos, visto que são mais pesadas, delicadas e susceptíveis a prejuízos de manipulação. No ensaio DEWS, a presença de uma região de instabilidade póspico deve ser observada, especialmente quando a lacuna entre a resistência à tração da matriz e a resistência associada ao ELS for elevada. No entanto, esse comportamento foi mitigado após exposição a elevadas temperaturas e para as amostras com teor de fibra de $70 \mathrm{~kg} / \mathrm{m}^{3}$, o qual também apresentou menor dispersão nos resultados. Ainda assim, para os três teores de fibras de aço utilizados neste estudo, não houve influência direta da região de instabilidade na determinação da resistência pós-fissuração associada ao ELU.

Embora o estudo das propriedades residuais do concreto não seja suficiente para representar o comportamento mecânico do CRFA durante o incêndio, os valores residuais são importantes em simulações numéricas usadas para verificar a necessidade de reparo e reforço em túneis. Logo, os resultados obtidos neste estudo poderão ser utilizados para a elaboração de equações constitutivas e servirão como dados de entrada em modelos numéricos de previsão de comportamento de aduelas pré-moldadas utilizadas para revestimento de túneis, além de outras aplicações estruturais, analisando seu nível de desempenho de acordo com o teor de fibra de aço adotado e são, portanto, uma referência importante para a definição de parâmetros de segurança para os elementos de CRFA. 


\subsection{Sugestões para trabalhos futuros}

A fim de obter uma completa parametrização do comportamento mecânico do concreto reforçado com fibras de aço (CRFA) quando submetido a elevadas temperaturas, sugere-se realizar os ensaios mecânicos durante o aquecimento (à quente). Assim, é possível comparar os valores de resistência à tração e resistência à tração pós-fissuração durante o aquecimento e após exposição a elevadas temperaturas (pós-resfriamento, como no caso deste estudo). No entanto, para este fim, exige-se condições laboratoriais específicas, especialmente devido ao custo elevado dos equipamentos e ao processo complexo de instrumentação das amostras durante o aquecimento. Para o ensaio DEWS, sugere-se utilizar o deslocamento vertical da máquina como forma de medida de controle do ensaio, a partir do estabelecimento de correlação prévia com os valores obtidos pelo extensômetro de garra.

O ensaio de flexão adotado neste estudo pode ser aplicado após aquecimento controlado das amostras prismáticas até as temperaturas-alvo estabelecidas $\left(150,300,450,600\right.$ e $\left.750{ }^{\circ} \mathrm{C}\right)$, a fim de correlacionar os resultados com os obtidos após exposição ao fogo. Assim como foi feito neste estudo com o ensaio DEWS, é possível obter uma parametrização mais completa, com o melhor entendimento do comportamento do compósito. Em relação ao DEWS, cabe avaliar a resposta do ensaio em sistema de controle fechado, visando analisar a real influência da instabilidade pós-fissuração, especialmente para as temperaturas mais baixas. Sugere-se ainda empregar o ensaio DEWS, após exposição das amostras a elevadas temperaturas, em concretos com outras fibras de aço, com fatores de forma distintos, além de concretos com matrizes cimentícias diferentes. É importante obter composições de concreto semelhantes às aplicadas em obras brasileiras que possuem elementos estruturais executados com CRFA, com o objetivo de definir parâmetros de segurança para estas aplicações estruturais.

A partir dos resultados obtidos neste estudo, pode-se ainda estabelecer equações constitutivas, que podem servir como dados de entrada em modelos numéricos de previsão de comportamento estrutural de elementos executados com CRFA submetidos a elevadas temperaturas. É importante para este fim obter também os resultados para o concreto sem adição de fibras de aço, especialmente para obter valores de energia de fratura. 


\section{REFERÊNCIAS BIBLIOGRÁFICAS}

ABDALLAH, S.; FAN, M.; CASHELL, K.A. Pull-out behaviour of straight and hooked-end steel fibres under elevated temperatures, Cement and Concrete Research, v. 95, p. 132-140, 2017.

AGRA, R. R. ; SERAFINI, R. ; FIGUEIREDO, A. D. ; BERTO, ANTONIO F. Avaliação dos efeitos do fogo na resistencia à tração residual do concreto reforçado com fibras de aço por meio do ensaio DEWS (Double Edge Wedge Splitting). In: 5th IBERIAN-LATINAMERICAN CONGRESS ON FIRE SAFETY. Porto. 2019.

AMERICAN CONCRETE INSTITUTE. ACI 544.5R-10, Report on the physical properties and durability of fiber-reinforced concrete, 2010.

. Design Considerations for Steel Fiber Reinforced Concrete. ACI 544-4R-88. In: Manual of concrete Practice. Detroit, Michigan, v. 85. 1988.

AMERICAN SOCIETY FOR TESTING MATERIALS. ASTM E119-2000: standard test methods for fire tests of building construction and materials. Philadelphia. 2000. 21 p.

ASSOCIAÇÃO BRASILEIRA DE NORMAS TÉCNICAS. NBR 5628: componenetes construtivos estruturais: determinação da resistência ao fogo. Rio de Janeiro, 2001. 6p.

NBR 8802: Concreto endurecido - Determinação da velocidade de propagação de onda ultrassônica. Rio de Janeiro, 1994. 8p.

NBR 14432: exigências de resistência ao fogo de elementos construtivos das edificações. Rio de Janeiro, 2001. 14p.

2012.

. NBR 15200: projeto de estruturas de concreto em situação de incêndio. Rio de Janeiro,

NBR 15530: Fibras de aço para concreto - Requisitos e métodos de ensaio. Rio de Janeiro, 2019. 38p.

2001.

. NBR NM 30: Agregado miúdo. Determinação da absorção de água. Rio de Janeiro, de Janeiro, 2006.

NBR NM 45: Agregados. Determinação da massa unitária e do volume de vazios. Rio

NBR NM 52: Agregado miúdo. Determinação da massa específica e massa específica aparente. Rio de Janeiro, 2009.

NBR NM 53: Agregado graúdo. Determinação da massa específica, massa específica aparente e absorção de água. Rio de Janeiro, 2003.

Janeiro, 2003

NBR NM 248: Agregados. Determinação da composição granulométrica. Rio de 
BARROS, J.A.O., SALEHIAN, H., PIRES, N.M.M.A., GONÇALVES, D.M.F. Design and testing elevated steel fibre reinforced self-compacting concrete slabs. In: Eighth RILEM International Symposium on Fibre Reinforced Concrete (BEFIB 2012), 2012, Guimarães. Fibre Reinforced Concrete: challenges and opportunities. Bagneux: RILEM Publications SARL, 2012.

BAZANT, Z.P. Analysis of pore pressure, thermal stress and fracture in rapidly heated concrete, in: Proceedings of the International Workshop on Fire Performance of High-Strength Concrete. NIST, Gaithersburg, Maryland, p. 155-164. 1997.

BAŽANT, Z.P.; KAPLAN, M.F. Concrete at high temperatures: material properties and mathematical models, 1996.

BORGES, L.A.C.; MONTE, R.; RAMBO, D.A.S.; FIGUEIREDO, A.D. Evaluation of postcracking behavior of fiber reinforced concrete using indirect tension test. Construction and Building Materials, 204, 2019, p. 510-519.

CANER, A.; ZLATANIC, S.; MUNFAH, N. Structural fire performance of concrete and shotcrete tunnel liners. Journal of Structural Engineering, v. 131, n. 12, p. 9020-9025, 2005.

CARPIO, J.M.; SERAFINI, R.; RAMBO, D.; DE LA FUENTE, A.; FIGUEIREDO, A.D. Assessment of the bearing capacity reduction of FRC elements subjected to fire, in: Proc. Fib Symp. 2019 Concr. - Innov. Mater. Des. Struct., Kraków, Poland, p. 1378-1386. 2019.

CAVALARO, S.; LÓPEZ, R.; TORRENTS, J.; AGUADO, A. Improved assessment of fibre content and orientation with inductive method in SFRC. Materials and Structures, 2014.

CHAN, Y.N.; LUO, X; SUN, W. Compressive Strength and Pore Structure of HighPerformance Concrete after Exposure to High Temperature up to $800^{\circ} \mathrm{C}$. Cement and Concrete Research, v. 30, p. 247-251. 2000.

CHEN, B.; LIU, J. Residual strength of hybrid-fiber-reinforced high-strength concrete after exposure to high temperatures, Cement and Concrete Research, v. 34, p. 1065-1069. 2004.

CHIES, J. A. Ensaios não destrutivos em concreto: Detecção de falhas no interior de estruturas de concreto com o uso de ultrassom. 2014. 133 f. Dissertação (Mestrado em Engenharia Civil) - Universidade Federal do Rio Grande do Sul, Porto Alegre, 2014.

CHOUMANIDIS, D.; BADOGIANNIS, E.; NOMIKOS, P.; SOFIANOS, A. Barcelona test for the evaluation of the mechanical properties of single and hybrid FRC, exposed to elevated temperature. Construction and Building Materials, v. 138, p. 296-305, 2017.

CONFORTI, A., TIBERTI, G., PLIZZARI, G.A., CARATELLI, A., MEDA, A. Precast tunnel segments reinforced by macro-synthetic fibers. Tunnelling and Underground Space Technology, Volume 63, Pages 1-11. 2017.

COSTA, C. N.; FIGUEIREDO, A. D.; SILVA, V. P. O fenômeno do lascamento ("spalling") nas estruturas de concreto armado submetidas a incêndio - uma revisão crítica. $\mathbf{4 4}^{\circ}$ Congresso Brasileiro do Concreto. Belo Horizonte, 2002. 
COSTA, C. N. Dimensionamento de elementos de concreto armado em situação de incêndio. Tese (Doutorado em Engenharia), Escola Politécnica, Universidade de São Paulo, 2008.

DEHN, F.; HERRMANN, A. Concreto reforçado com fibra de aço (SFRC) em situação de incêndio - requisitos normativos, pré-normativos e códigos-modelo. Concreto \& Construções. Ed. 87. São Paulo, 2017.

DE LA FUENTE, A.; MONTE, R.; FIGUEIREDO, A. D.; GALOBARDES, I. Projeto de segmentos para obras de túneis com tuneladora utilizando concreto com fibras. Concreto \& Construções. Ed. 88. São Paulo, 2017.

DESTRÉE, X. Steel-fibre-only reinforced concrete in free suspended elevated slabs. Concrete Engineering International. Spring, pp 47-.9, 2009.

di PRISCO, M.; PLIZZARI, G.; VANDEWALLE, L. Fiber reinforced concrete: new design perspectives. Material and Structures, v. 42, p. 1261-1281, 2009.

di PRISCO, M.; PLIZZARI, G.; VANDEWALLE, L. Fiber reinforced concrete in the new fib Model Code. In: 3rd fib International Congress. Washington, 12pp, 2010.

di PRISCO, M.; FERRARA, L.; LAMPERTI, M.G.L. Double edge wedge splitting (DEWS): an indirect tension test to identify post-cracking behaviour of fibre reinforced cementitious composites. Materials and Structures, vol. 46, Issue 11, p. 1893-1918, 2013.

EUROPEAN COMMITTEE FOR STANDARDIZATION. EN 14651: Test method for metallic fiber-reinforced concrete - Measuring the flexural tensile strength (limit of proportionality (LOP), residual), CEN, London, 2007. 15p.

. EN 1991-1-2: Eurocode 1: actions on structures - part 1.2: general actions - actions on structures exposed to fire. Brussels: CEN, 2002. 59 p.

EN 1992-1-2: Eurocode 2: Design of concrete structures - Part 1-2: General rules Structural fire design, 2004.

FÉdÉRATION INTERnATIONALE DU BÉTON - FIB. Fib Model Code for Concrete Structures 2010. Switzerland, 2013. 402p.

FÉDÉRATION INTERNATIONALE DU BÉTON. fib Bulletin 38, Fire design of concrete structures - materials, structures and modelling - State of Art Report. Lausanne, Switzerland, 2007.

FÉDÉRATION INTERNATIONALE DU BÉTON. fib Bulletin 46, Fire design of concrete structures - structural behaviour and assessment, State-of-art report. Lausanne, Switzerland, 2008.

FÉDÉRATION INTERNATIONALE DU BÉTON. fib Bulletin 83, Precast tunnel segments in fibre-reinforced concrete. State-of-the-art report. Bulletin 83. Lausanne, Switzerland, 2017.

FELICETTI, R.; GAMBAROVA, P.G.; KHOURY, G.A; NATALI-SORA, M.P. Mechanical Behaviour of HPC and UHPC in Direct Tension at High Temperature and after Cooling. 5th 
RILEM Symp. BEFIB'2000, ed. by P. Rossi and G. Chanvillard, RILEM Publ. S.A.R.L., Lyon (France), p. 749-758. 2000.

FERNANDES, B.; GIL, A.M.; BOLINA, F.L.; TUTIKIAN, B.F. Microstructure of concrete subjected to elevated temperatures: physico-chemical changes and analysis techniques. IBRACON Structures and Materials Journal, Volume 10, Number 4, p. 838 - 863, 2017.

FIGUEIREDO, A. D. Concreto reforçado com fibras. Tese (Livre docência). Escola Politécnica, Universidade de São Paulo. São Paulo. 2011a. 247p.

FIGUEIREDO, A. D. Concreto com fibras. Capítulo 37. In: CONCRETO: Ciência e tecnologia. 2ed. São Paulo: Instituto Brasileiro do Concreto (IBRACON), 2011b, v.2, p. 13271365 .

FIGUEIREDO, A. D.; CECCATO, M. R. Workability Analysis of Steel Fiber Reinforced Concrete Using Slump and Ve-Be Test. Materials Research, 2015.

FRENCH ASSOCIATION OF CIVIL ENGINEERING. AFGC:2013, Ultra high-performance fibre-reinforced concretes, 2013.

GALLUCCI, E.; ZHANG, X.; SCRIVENER, K. L. Effect of temperature on the microstructure of calcium silicate hydrate (C-S-H), Cement and Concrete Research, v. 53, p. 185-195, 2013.

GALOBARDES, I.; FIGUEIREDO, A. D. Correlation between beam and Barcelona tests for FRC quality control for structural applications. In: 8th International Conference on Fibre Concrete. Fibre Concrete 2015. Prague: Czech Technical University in Prague, p. 1-10, 2015.

GERMAN INSTITUTE FOR STANDARDIZATION. DIN EN 1992-1-2:2010-12, Eurocode 2: Design of concrete structures - Part 1-2: General rules - Structural fire design, 2012.

GERMAN COMMITTEE FOR REINFORCED CONCRETE. DAfStb:2012-11, Steel fire reinforced concrete, 2012.

GIONGO, J. S. Concreto armado: introdução e propriedades dos materiais. Escola de Engenharia de São Carlos (USP). Departamento de Engenharia de Estruturas. 2007. nevi

HANDOO, S.K.; AGARWAL S.; AGARWAL S.K. Physicochemical, Mineralogical and Morphological Characteristics of Concrete Exposed to Elevated Temperatures. Cement and Concrete Research, v. 32, pp. 1009-1018, 2002.

INTERNATIONAL ORGANIZATION FOR STANDARDIZATION. ISO 834: fire resistance tests: elements of building construction. Part 1.1: general requirements for fire resistance testing. Geneva, 1990. Revision of first edition (ISO 834:1975).

ITALIAN NATIONAL RESEARCH COUNCIL. CNR-DT 204/2006. Guide for the design and construction of fibre reinforced concrete structures, 2007.

JANSSON, A.; GYLLTOFT, K.; LÖFGREN, I. Design methods for fibre-reinforced concrete: a state-of-the-art review. In: Nordic Concrete Research, 2008. 
KALIFA, P. High temperature behaviour of HPC with polypropylene fibres: from spalling to microstructure. Cement and Concrete Research, v. 31, p. 1487-1499. 2001.

KIM, J.; LEE, G.P.; MOON, D.Y. Evaluation of mechanical properties of steel-fibre reinforced concrete exposed to high temperatures by double-punch test. Construction and Building Materials, v. 79, p. 182-191. 2015.

KODUR, V.K.R.; SULTAN, M.A. Effect of temperature on thermal properties of high-strength concrete, Journal Mater. Civ. Eng., 2003.

LiAO, L., DE LA FUENTE, A., CAVAlARO, S., AGUADO, A. Design of FRC tunnel segments considering the ductility requirements of the Model Code 2010. Tunnelling and Underground Space Technology, v. 47, p. 200-210. 2015.

LILLIU, G.; MEDA, A. Nonlinear Phased Analysis of Reinforced Concrete Tunnels Under Fire Exposure Article. Journal of Structural Fire Engineering, v. 4, n. 3. 2013.

LIM, S.; MONDAL, P. Micro- and nano-scale characterization to study the thermal degradation of cement-based materials. Materials Characterization, v. 92, p. 15-25, 2014.

LIU, K.; LU, L.; WANG, F.; LIANG, W. Theoretical and experimental study on multi-phase model of thermal conductivity for fiber reinforced concrete, Construction and Building Materials, v. 148, p. 465-475, 2017.

MA, Q.; GUO, R.; ZHAO, Z.; LIN, Z.; HE, K. Mechanical properties of concrete at high temperature-A review. Construction and Building Materials, v. 93, p. 371-383. 2015.

MEHTA, P. K.; MONTEIRO, P. J. M. Concreto: estrutura, propriedades e materiais. São Paulo: Ibracon, 2008. 674p.

MOLINS, C., AGUADO, A., SALUDES, S. Double Punch Test to control the energy dissipation in tension of FRC (Barcelona test). Materials and Structures, v. 42, p. 415-425. 2008.

MORENO JUNIOR, A. L.; MOLINA, J. C. Considerações de Interesse Sobre a Avaliação em Laboratório de Elementos Estruturais em Situação de Incêndio: contribuições à revisão da NBR 5628:2001. Ambiente Construído, Porto Alegre, v. 12, n. 4, p. 37-53. 2012.

NEVILLE, A. M. Propriedades do concreto. São Paulo: PINI, 1997.

NINCE, A. A.; COSTA, C. N.; FIGUEIREDO, A. D.; SILVA, V. P. E. Influência das fibras de polipropileno no comportamento do concreto de alta resistência endurecido submetido à ação térmica. In: 45o Congresso Brasileiro do Concreto. Vitória, 2003. Anais. Instituto Brasileiro do Concreto (IBRACON). São Paulo, 2003.

NOUMOWÉ, A. Mechanical properties and microstructure of high strength concrete containing polypropylene fibres exposed to temperatures up to $200^{\circ} \mathrm{C}$. Cement and Concrete Research, $n^{\circ} 35$, p. 2192-2198. 2005. 
NTZEREMES, P.; KIRYTOPOULOS, K. Evaluating the role of risk assessment for road tunnel fire safety: A comparative review within the EU. Journal of Traffic and Transportation Engineering, v. 6 (3), p. 282-296, 2019.

NUNES, L. N.; AGOPYAN, V. A influência do fator de forma da fibra na tenacidade à flexão do concreto reforçado com fibras de aço. 26 p. Boletim Técnico, Série BT/PCC/225 - Escola Politécnica da Universidade de São Paulo, São Paulo, 1998.

PENG, G.F.; HUANG, Z.S. Change in microstructure of hardened cement paste subjected to elevated temperatures. Construction and Building Materials, v. 22, n. 4, p. 593-599, 2008.

PÉREZ, A. H. Diseño prestacional de túneles en situación de incendios. Modelos FDS. Aplicación a un túnel de metro. 2016.

PHAN, L.T; CARINO, N.J. Effects of Test Conditions and Mixture Proportions on Behavior of High-Strength Concrete Exposed to High Temperatures. ACI-Materials Journal, v. 99, n.1, p. 54-66. 2002.

POON, C. S.; SHUI, Z. H.; LAM, L. Compressive behavior of fiber reinforced highperformance concrete subjected to elevated temperatures. Cement and Concrete Research. $N^{\circ} 34$, p. 2215-2222. 2004.

PUJADAS, P. Caracterización y diseño del hormigón reforzado con fibras plásticas. Tesis Doctoral - Universitat Politècnica de Catalunya, Barcelona, 2013.

PURKISS, J. A. Fire Safety Engineering Design of Structures. 2. ed. Burlington: Elsevier, 2007.

RAI, B. Molecular Modeling for the Design of Novel Performance Chemicals and Materials, 1st ed., CRC Press, 2012.

RAMBO, D. A. S.; BLANCO, A.; DE FIGUEIREDO, A. D.; DOS SANTOS, E. R. F.; TOLEDO, R. D.; GOMES, O. D. F. M. Study of temperature effect on macro-synthetic fiber reinforced concretes by means of Barcelona tests: An approach focused on tunnels assessment. Construction and Building Materials. v. 158, 443-453. 2018.

RUANO, G.; ISLA, F.; LUCCIONI, B.; ZERBINO, R.; GIACCIO, G. Steel fibers pull-out after exposure to high temperatures and its contribution to the residual mechanical behavior of high strength concrete, Construction and Building Materials, v. 163, p. 571-585. 2018.

SALVADOR, R.P.; CAVALARO, S.H.P.; SEGURA, I.; FIGUEIREDO, A.D.; PÉREZ, J. Early age hydration of cement pastes with alkaline and alkali-free accelerators for sprayed concrete, Construction and Building Materials, v. 111, p. 386-398. 2016.

SALVADOR, R. P., FIGUEIREDO, A. D. Análise comparativa de comportamento mecânico de concreto reforçado com macrofibra polimérica e com fibra de aço. Revista Matéria, v.18, n.2, p.1273 - 1285, 2013.

SCHNEIDER, U. Concrete at high temperatures - A general review. Fire Safety Journal, v. 88. 1988. 
SCRIVENER, K.; SNELLINGS, R.; LOTHENBACH, B. A Practical Guide to Microstructural Analysis of Cementitious Materials, CRC Press, 2017.

SERAFINI, R.; RAMBO, D. A. S.; FIGUEIREDO, A. D. Concreto reforçado com fibras em situação de incêndio. Concreto \& Construções. Ed. 89. São Paulo, 2018.

SERAFINI, R.; DANTAS, S.R.A. ; SALVADOR, R.P. ; AGRA, R.R. ; RAMBO, D.A.S.; BERTO, A.F.; FIGUEIREDO, A.D. Influence of fire on temperature gradient and physicalmechanical properties of macro-synthetic fiber reinforced concrete for tunnel linings. Construction and Building Materials, v. 214, p. 254-268, 2019a.

SERAFINI, R.; AGRA, R. R. ; MONTE, R. ; FIGUEIREDO, A. D. . The effect of elevated temperatures on the tensile properties of Steel Fiber Reinforced Concrete by means of Double Edge Wedge Splitting test: preliminary results. In: 10th international conference on fracture mechanics of concrete and concrete structures, Bayonne, France, $2019 \mathrm{~b}$.

SERAFINI, R.; MENDES, L.M.S.; SALVADOR, R.P.; FIGUEIREDO, A.D. The effect of elevated temperatures on the properties of cold-drawn steel fibers. Magazine of Concrete Research, p. 1-28, 2020a.

SERAFINI, R.; AGRA, R. R. ; SALVADOR, R. P. ; ANTEQUERA, A. L. F. ; FIGUEIREDO, A. D. . Double Edge Wedge Splitting test to characterize the design post-cracking parameters of fiber reinforced concrete subjected to high temperatures. Journal of Materials in Civil Engineering, 2020b (in press).

SERAFINI, R.; AGRA, R. R.; BITENCOURT JUNIOR, L. A. G.; ANTEQUERA, A. L. F.; FIGUEIREDO, A. D. Bond-slip response of steel fibers after exposure to elevated temperatures: Experimental program and design-oriented constitutive equation. Composite Structures, v. 255, 2021.

SILVA, V. P. Projeto de estruturas de concreto em situação de incêndio conforme ABNT NBR 15200:2012. São Paulo: Blucher, 237p, 2012.

SKOBLINSKAYA, N. N.; KRASILNIKOV, K. G. Changes in crystal structure of ettringite on dehydration. 1, Cement and Concrete Research, v. 5, p. 381-393, 1975.

SUHAENDI, S.L.; HORIGUCHI, T. Effect of short fibers on residual permeability and mechanical properties of hybrid fibre reinforced high strength concrete after heat exposition, Cement and Concrete Research, v. 36, p. 1672-1678. 2006.

SUKONTASUKKUL, P.; POMCHIENGPIN, W.; SONGPIRIYAKIJ, S. Post-crack (or postpeak) flexural response and toughness of fiber reinforced concrete after exposure to high temperature. Construction and Building Materials, v. 24, p. 1967-1974. 2010.

TAI, Y. S.; PAN, H. H.; KUNG, Y. N. Mechanical properties of steel fiber reinforced reactive powder concrete following exposure to high temperature reaching $800{ }^{\circ} \mathrm{C}$. Nuclear Engineering and Design, v. 241, p. 2416-2424. 2011. 
TAJUELO RODRIGUEZ, E.; GARBEV, K.; MERZ, D.; BLACK, L.; RICHARDSON, I.G. Thermal stability of C-S-H phases and applicability of Richardson and Groves' and Richardson C-(A)-S-H(I) models to synthetic C-S-H, Cement and Concrete Research. v. 93, p. 45-56, 2017.

TAYLOR, H. F.W. Cement chemistry. Thomas Telford, 1997.

TORRENTS, J.; BLANCO, A.; PAJUDAS, P.; AGUADO, A.; JUAN-GARCÍA, P.; SÁNCHEZ-MORAGUES, M. Inductive method for assessing the amount and orientarion of steel fibers in concrete. Materials and Structures, v. 45, p. 1577-1592, 2012.

ULM, F. J.; COUSSY, O.; BAZANT, Z. Chemoplastic softening inrapidly heated concrete. J. Eng. Mech. p. 272-282. 1999.

UNE 83515: 2010 - Hormigones con fibras. Determinación de la resistencia a fisuración, tenacidad y resistencia residual a tracción. Método Barcelona. The Spanish Association for Standardisation. Madrid, 2010.

XING, Z.; BEAUCOUR, A. L.; HEBERT , R.; NOUMOWE, A.; LEDESERT, B. Aggregate's influence on thermophysical concrete properties at elevated temperature. Construction and Building Materials. v. 95, p. 18-28. 2015.

YAN, Z.; SHEN Y.; ZHU H.; LI X.; LU Y. Experimental investigation of reinforced concrete and hybrid fibre reinforced concrete shield tunnel segments subjected to elevated temperature. Fire Safety Journal, v. 71, p. 86-99. 2015.

YERMAK, N.; PLIYA, P.; BEAUCOUR, A. L.; SIMON, A.; NOUMOWÉ, A. Influence of steel and/or polypropylene fibres on the behaviour of concrete at high temperature: Spalling, transfer and mechanical properties. Construction and Building Materials, v. 132, p. 240-250. 2017.

ZAGO, C. da S.; MORENO JUNIOR, A. L.; MARIN, M. C. Considerações sobre o desempenho de estruturas de concreto pré-moldado em situação de incêndio. Ambiente Construído, Porto Alegre, v. 15, n. 1, p. 49-61. 2015.

ZEIML, M.; LEITHNER, D.; LACKNER, R.; MANG, H. A. How do polypropylene fibers improve the spalling behaviour of in-situ concrete? Cement and Concrete Research. V. 36, p. 929-942. 2006.

ZHENG, W.; LI, H.; WANG, Y. Compressive stress-strain relationship of steel fiber-reinforced reactive powder concrete after exposure to elevated temperatures. Construction and Building Materials, v. 35, p. 931-940. 2012.

ZOLLO, R. F. Fiber-reinforced Concrete: an Overview after 30 Years of Development. Cement and Concrete Research, v. 19, p. 107-122. 1997. 


\section{APÊNDICE A: Curvas individuais experimentais obtidas por meio do Ensaio DEWS e representação da região de instabilidade pós-pico}

Figura A1 - Curvas experimentais e médias obtidas por meio do ensaio DEWS para a dosagem de fibras de aço
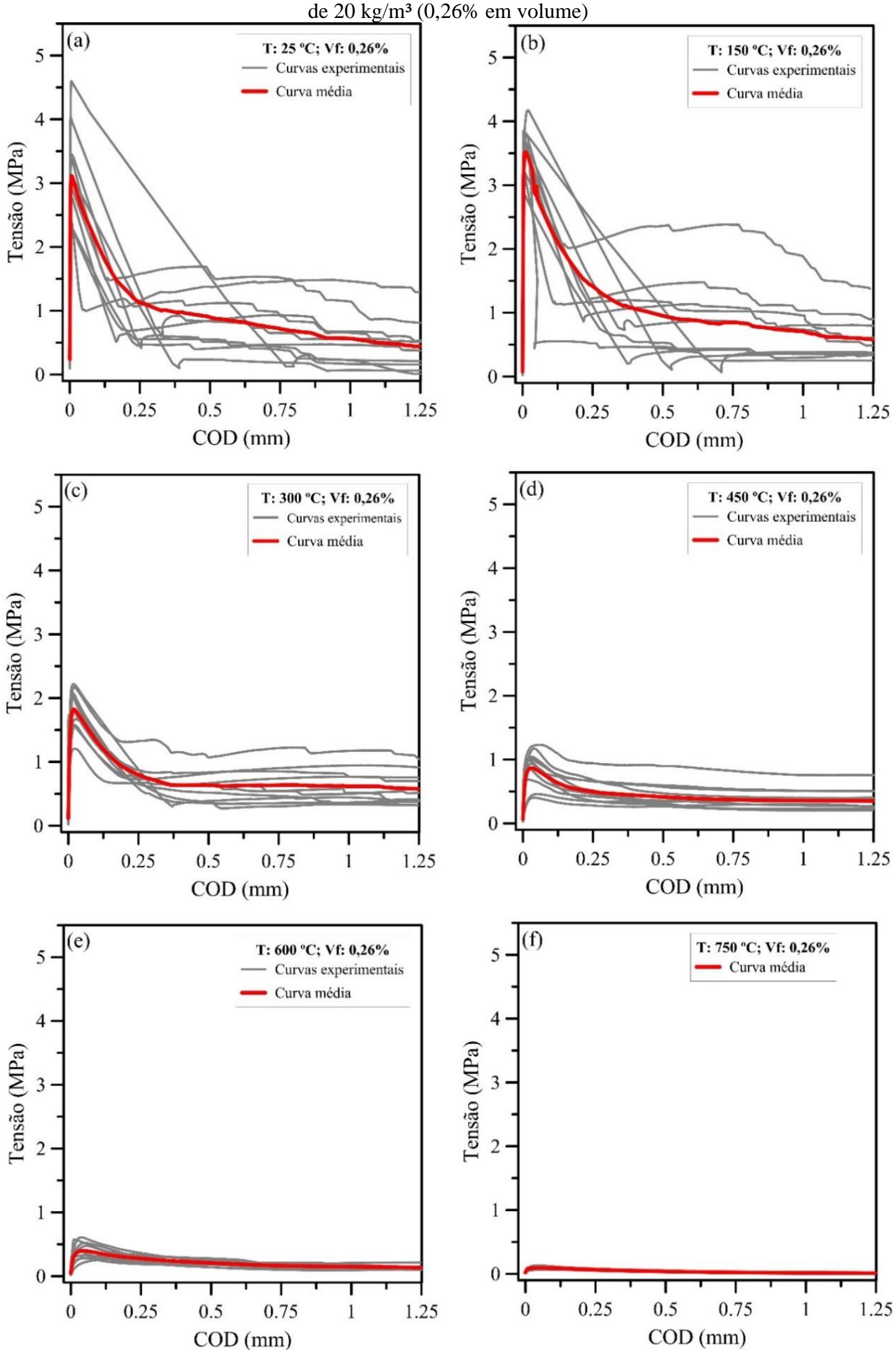

Fonte: Elaborado pelo autor 
Figura A2 - Curvas experimentais e médias obtidas por meio do ensaio DEWS para a dosagem de fibras de aço de $35 \mathrm{~kg} / \mathrm{m}^{3}(0,45 \%$ em volume $)$
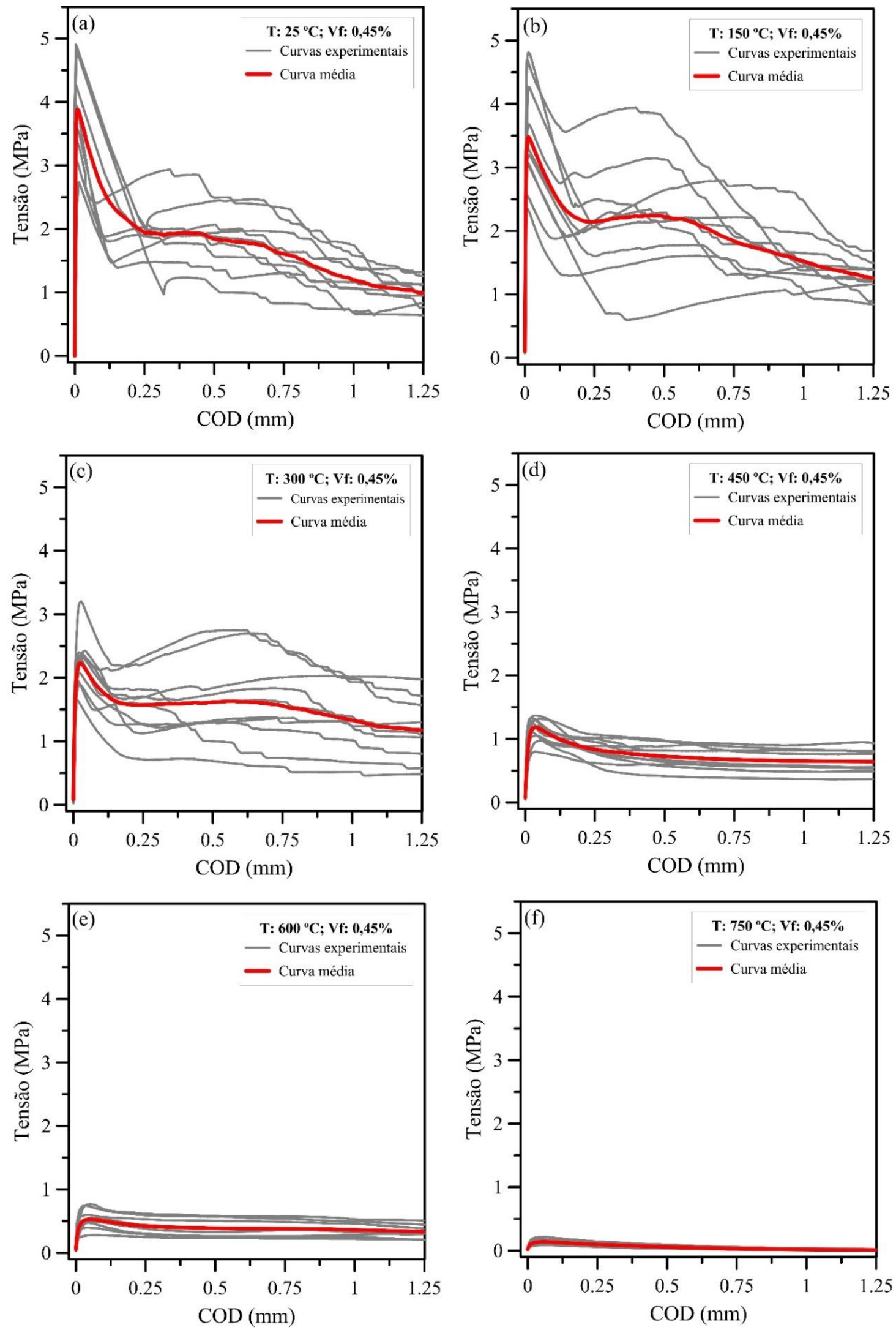

Fonte: Elaborado pelo autor 
Figura A3 - Curvas experimentais e médias obtidas por meio do ensaio DEWS para a dosagem de fibras de aço de $70 \mathrm{~kg} / \mathrm{m}^{3}(0,90 \%$ em volume $)$
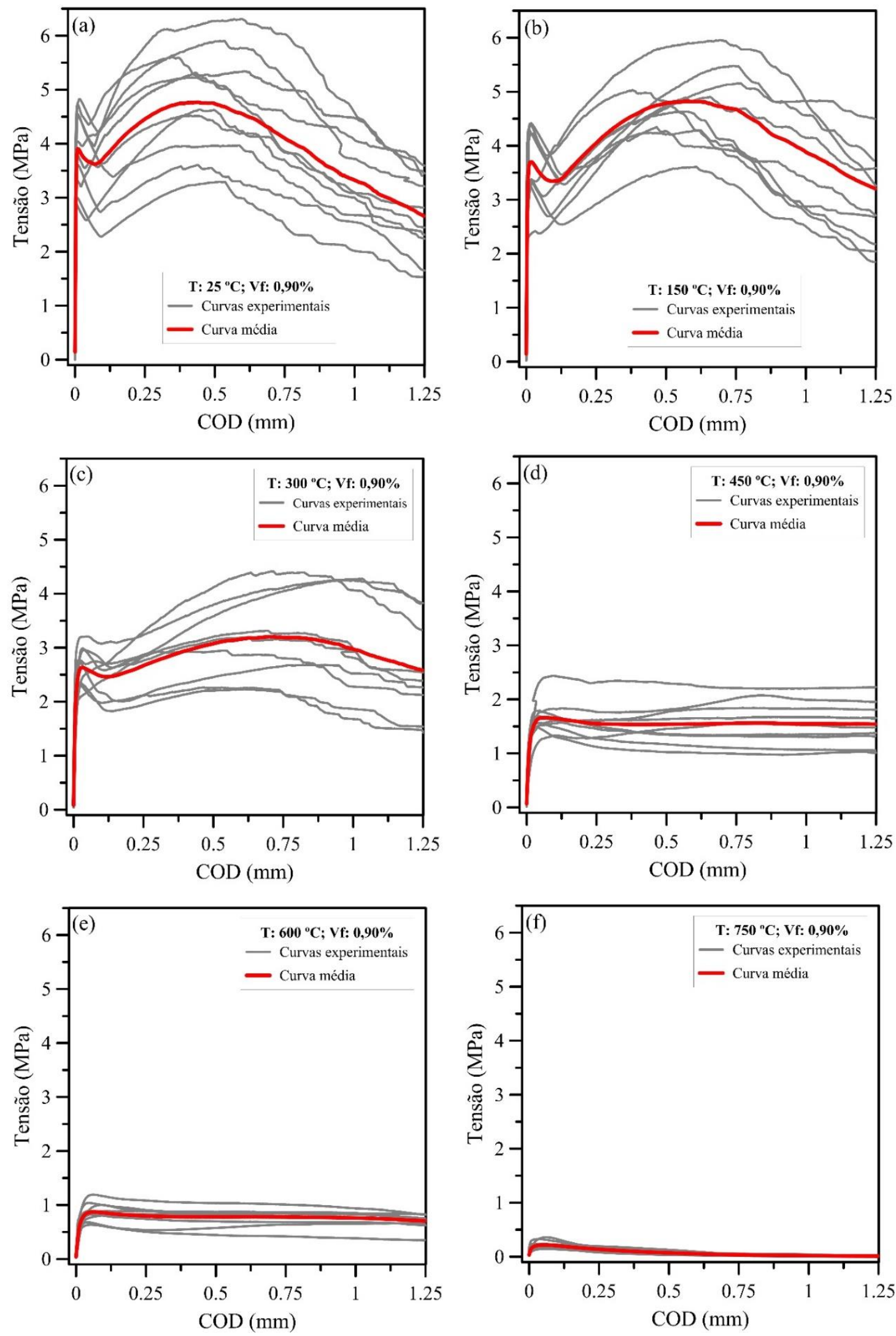

Fonte: Elaborado pelo autor 
Figura A4 - Representação da região de instabilidade pós-pico
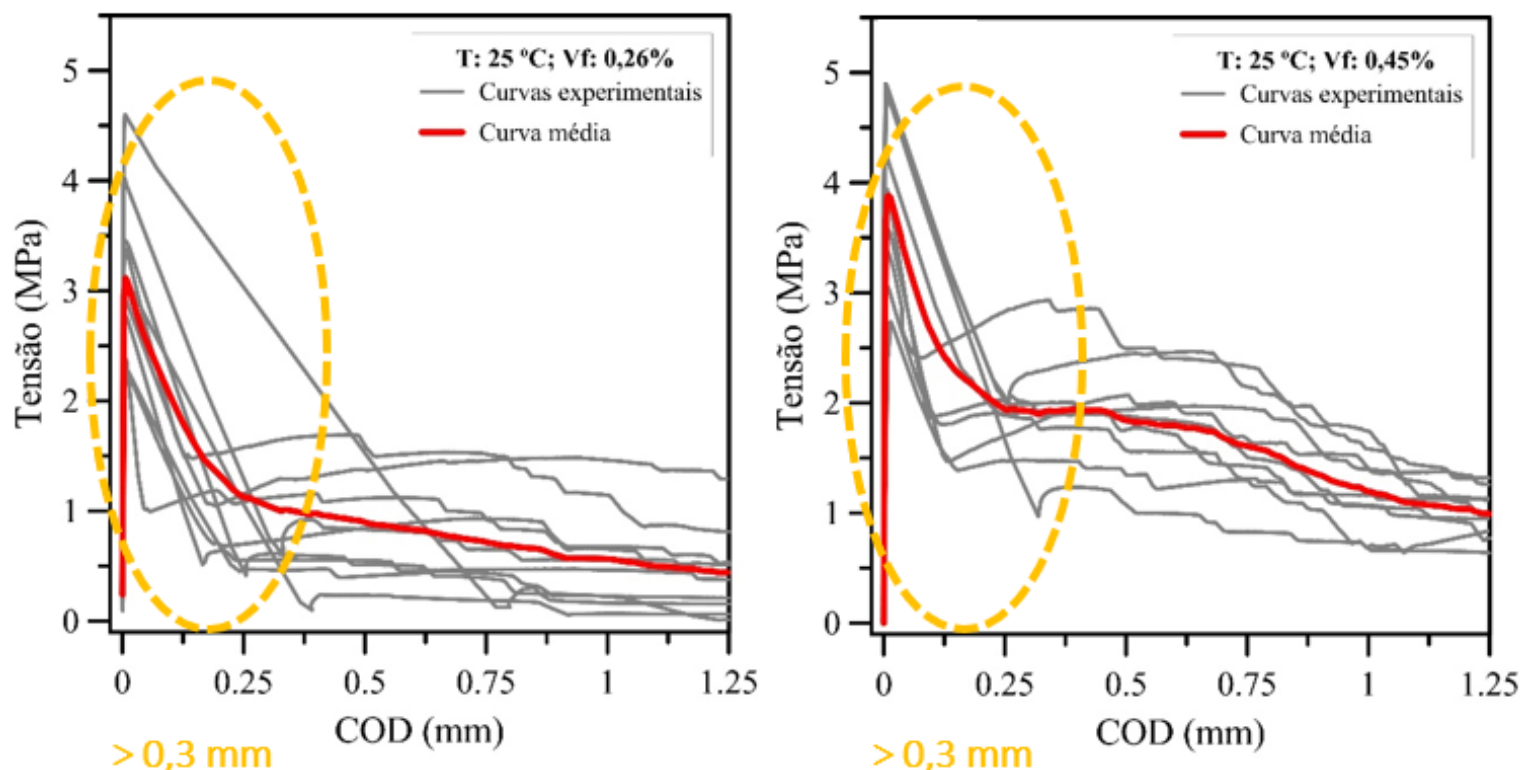

Fonte: Elaborado pelo autor

Figura A5 - Redução da instabilidade por meio da exposição da amostra a elevadas temperaturas ou utilização de teores de fibra de aço elevados
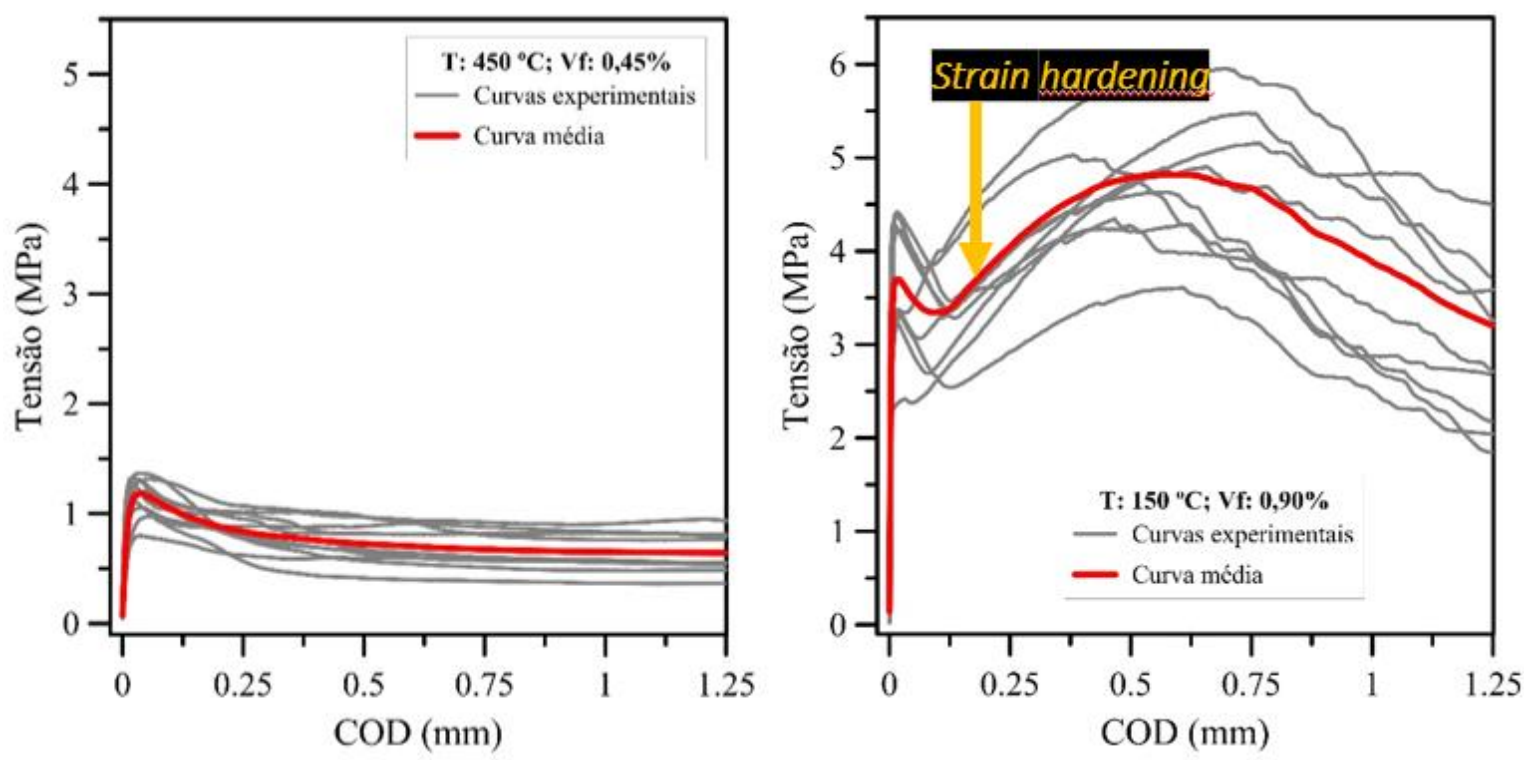

Fonte: Elaborado pelo autor 


\section{APÊNDICE B: Erro admissível e tamanho amostral}

As Figuras B1, B2 e B3 apresentam a quantidade de amostras necessárias em função do erro admissível ao analisar as propriedades de tração do compósito, para os teores de fibra de aço de 20,35 e $70 \mathrm{~kg} / \mathrm{m}^{3}$, respectivamente. A análise para a temperatura de $750{ }^{\circ} \mathrm{C}$ não foi considerada nesta discussão, visto que apresentou propriedades de tração praticamente insignificantes. As análises conduzidas utilizando estatística inferencial e intervalo de confiança de $95 \%$ mostra que o número de amostras necessários aumenta com a redução do erro admissível para o ensaio DEWS.

Uma dispersão significativa na resposta pós-fissuração é considerada fator intrínseco associado ao CRF, especialmente quando avaliado em amostras de pequenas dimensões, visto que a área de fratura também é reduzida, tal como ocorre no ensaio DEWS. Assim, principalmente nas primeiras temperaturas analisadas, notou-se uma variação da ordem de $25 \%$ na resposta do ensaio, o que também está relacionada ao baixo teor de fibras utilizado neste estudo, abaixo do volume crítico, o que reduz a quantidade de fibras controlando o processo de fissuração. Somado a isto, fibras dúcteis, como as de aço, são menos propensas a se espalhar de forma homogênea durante a moldagem. Além da variabilidade intrínseca do material, que por si só exige uma quantidade considerável de amostras para o ensaio, nota-se ainda que essa demanda é particularmente maior para as propriedades de tração pós-fissuração, especialmente quando se utiliza baixos teores de fibra de aço (Figura B1), com reduções consideráveis nas propriedades de tração pós-aquecimento.

Para o teor de fibra de aço de $20 \mathrm{~kg} / \mathrm{m}^{3}(0,26 \%$ em volume), ao analisar a resistência à tração da matriz, o uso de 10 amostras cúbicas garante um erro máximo admissível de 25\%, entretanto, grande variabilidade foi apresentada nas propriedades de tração pós-fissuração, especialmente à temperatura ambiente. Levando em conta apenas a análise pós-temperatura, o uso de 15 amostras acarreta erro admissível máximo de 35\%. Ao aumentar o teor de fibras, nota-se que a variabilidade diminui, o que implica na diminuição da quantidade de amostras para o mesmo nível de erro admissível. Logo, para o teor de fibra de aço de $35 \mathrm{~kg} / \mathrm{m}^{3}(0,45 \%$ em volume), os resultados indicam que o uso de 15 amostras cúbicas $(1=100 \mathrm{~mm})$ garante um erro máximo admissível de 25\%, enquanto 10 amostras cúbicas são necessárias para um erro admissível de $\sim 30 \%$, que é o caso deste estudo. Por fim, para o teor de $70 \mathrm{~kg} / \mathrm{m}^{3}(0,90 \%$ em volume), os resultados indicam que o uso de o uso de 15 amostras cúbicas $(1=100 \mathrm{~mm})$ garante 
um erro máximo admissível de 20\%, enquanto 10 amostras cúbicas são necessárias para um erro admissível de $\sim 25 \%$, que é o caso deste estudo.

Figura B1 - Número de amostras necessárias em função do erro admissível para: (a) $\mathrm{f}_{\mathrm{tc}}$; (b) $\mathrm{ft}_{0,25}-\mathrm{ELS}$; (c) $\mathrm{ft}_{1,25}$
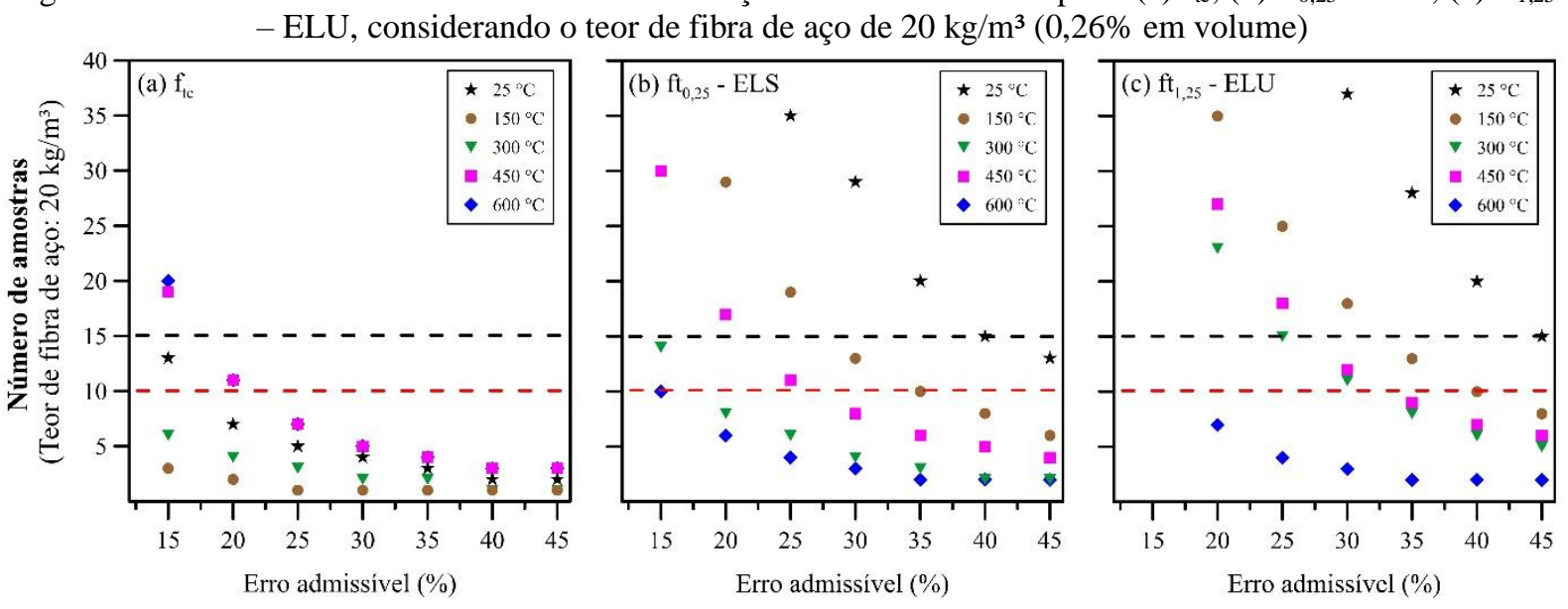

Fonte: Elaborado pelo autor

Figura B2 - Número de amostras necessárias em função do erro admissível para: (a) $\mathrm{ftc}_{\mathrm{tc}}$; (b) $\mathrm{ft}_{0,25}-\mathrm{ELS}$; (c) $\mathrm{ft}_{1,25}$
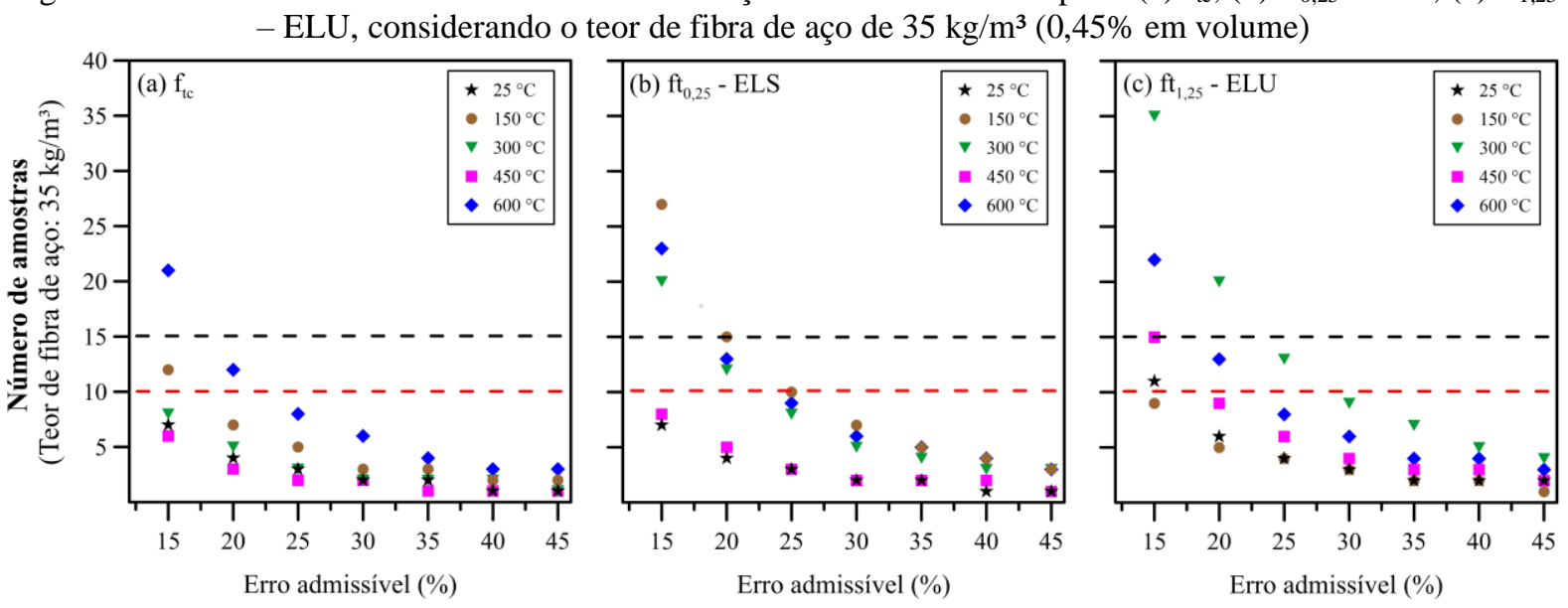

Fonte: Elaborado pelo autor

Figura B3 - Número de amostras necessárias em função do erro admissível para: (a) $\mathrm{f}_{\mathrm{tc}}$; (b) ftto,25 - ELS; (c) $\mathrm{ft}_{1,25}$
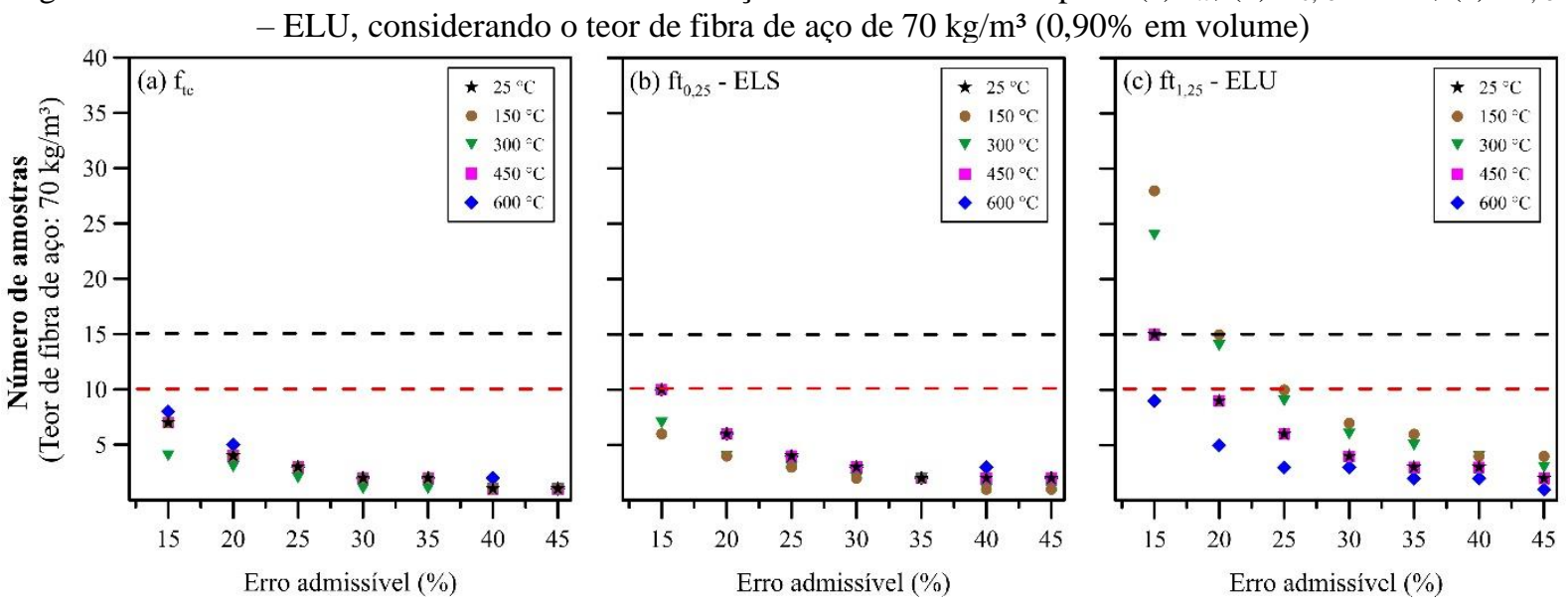

Fonte: Elaborado pelo autor 